Portland State University

PDXScholar

\title{
Coastal Crossing of the Elastic Strain Zero-Isobase, Cascadia Margin, South Central Oregon Coast
}

Gregory George Briggs

Portland State University

Follow this and additional works at: https://pdxscholar.library.pdx.edu/open_access_etds

Part of the Geology Commons

Let us know how access to this document benefits you.

Recommended Citation

Briggs, Gregory George, "Coastal Crossing of the Elastic Strain Zero-Isobase, Cascadia Margin, South Central Oregon Coast" (1994). Dissertations and Theses. Paper 4739.

https://doi.org/10.15760/etd.6623

This Thesis is brought to you for free and open access. It has been accepted for inclusion in Dissertations and Theses by an authorized administrator of PDXScholar. Please contact us if we can make this document more accessible: pdxscholar@pdx.edu. 
An abstract and thesis of Gregory George Briggs for the Masters of Science in Geology were presented August 3, 1994 and accepted by the thesis committee and the department.

COMMITTEE APPROVALS:
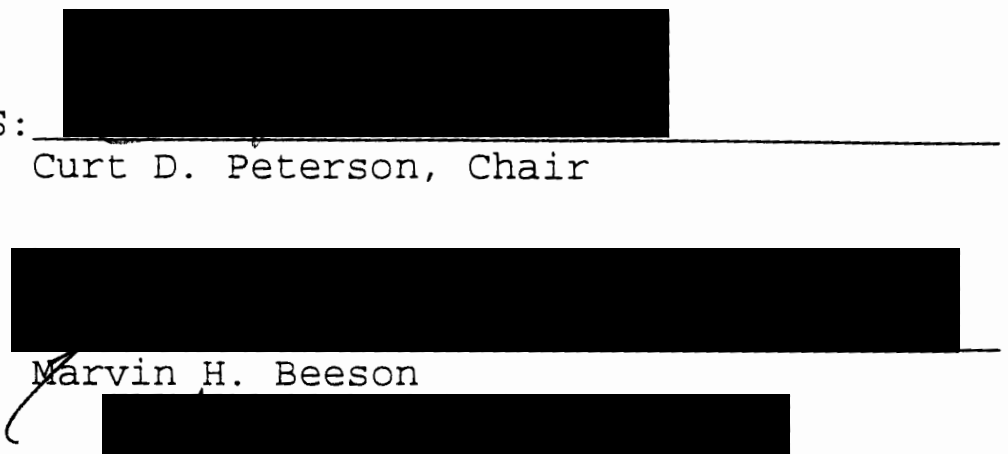

Scott F. Burns

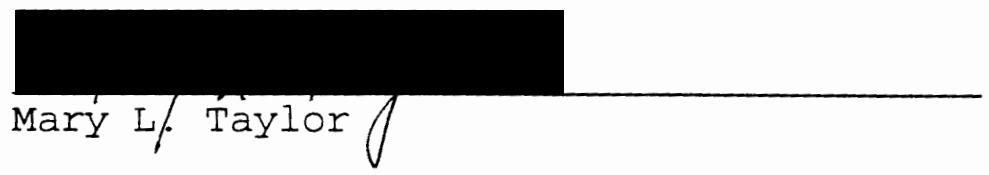

DEPARTMENT APPROVAL:

Marvin H. Beeson, Chair, Department of Geology

ACCEPTED FOR PORTLAND STATE UNIVERSITY BY THE LIBRARY by onstlecented $/ 98 x$ 
ABSTRACT

An abstract of the thesis of Gregory George Briggs for the Masters of Science in Geology presented August 3, 1994.

Title: Coastal Crossing of the Elastic strain Zero-Isobase, Cascadia Margin, South Central Oregon Coast.

The analysis of marsh cores from the tidal zones of the Siuslaw, Umpqua, and Coos River systems on the south-central Oregon coast provides supporting evidence of coseismic subsidence resulting from megathrust earthquakes and reveals the landward extent of the zero-isobase. The analysis is based on lithostratigraphy, paleotidal indicators, microfossil paleotidal indicators, and radiocarbon age. Coseismic activity is further supported by the presence of anomalous thin sand layers present in certain cores. The analysis of diatom assemblages provides evidence of relative sea-level displacement on the order of 1 to $2 \mathrm{~m}$. The historic quiescence of local synclinal structures in the coos Bay area together with the evidence of prehistoric episodic burial of wetland sequences suggests that the activity of these structures is linked to megathrust releases. The distribution of cores containing non-episodically buried marshes and cores that show episodically buried wetlands within this area suggests that the landward extent of the zero-isobase is between $100 \mathrm{~km}$ and $120 \mathrm{~km}$ from the trench. 
The zero-isobase has a minimum width of 10 to $15 \mathrm{~km}$.

Radiocarbon dating of selected buried peat sequences yields an estimated recurrence interval on the order of 400 years. The apparent overlapping of the landward margin of both the upperplate deformation zone (fold and/or thrust fault belt) and the landward extent of the zero-isobase is interpreted to represent the landward limit of the locked zone. The earthquake magnitude is estimated to be 8.5 based on an arbitrary rupture length of $200 \mathrm{~km}$ and a locked zone width of $105 \mathrm{~km}$. The identification of the zero-isobase on the southcentral Oregon coast is crucial to the prediction of regional coseismic subsidence and tsunami hazards, the testing of megathrust dislocation models, and the estimation of megathrust rupture areas and corresponding earthquake magnitudes in the Cascadia Margin. 
COASTAL CROSSING OF THE ELASTIC STRAIN ZERO-ISOBASE, CASCADIA MARGIN, SOUTH CENTRAL OREGON COAST.

by

GREGORY GEORGE BRIGGS

A thesis submitted in partial fulfillment of the requirements for the degree of

\author{
MASTERS OF SCIENCE \\ in \\ GEOLOGY
}

Portland State University

1994 
ACKNOWLEDGMENTS

This thesis is dedicated to my father and to my little grandson, Tristan Michael, both who reminded me that there is a time for play. A special thanks goes to my research advisor, Dr. Curt Peterson, who shared his knowledge with me and spent many hours discussing and reviewing this thesis. His support and encouragement have been invaluable. I would also like to acknowledge the other members of my committee, Dr. Marvin Beeson, Dr. Scott Burns, and Dr. Mary Taylor, and thank them for their helpful comments which contributed to my thesis and for their encouragement throughout my years at Portland state University. I would like to express a special thanks to Janet cruden for showing me how to identify diatoms and increasing my understanding of this complex area of research. I admire her scholarship and dedication to her research. She is a testimony to the fact that learning does not end at retirement. Gene Pierson was a great help in working out the logistics of my field research. The field assistance of Betsy McLeod and Aaron wieting is much appreciated. Thanks also to Mark Darienzo for his data from South Slough. This thesis was supported by the U. S. Geological Survey National Earthquake Hazards Reduction Program. I am grateful for the funding from the state of Oregon Department of Geology and Mineral Industries which allowed me to complete the radiocarbon dating. 
TABLE OF CONTENTS

PAGE

ACKNOWLEDGMENTS .......................

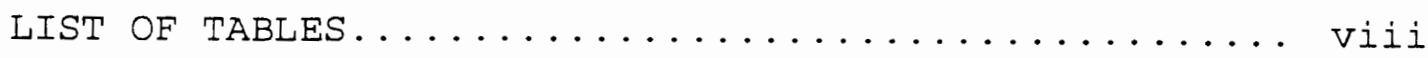

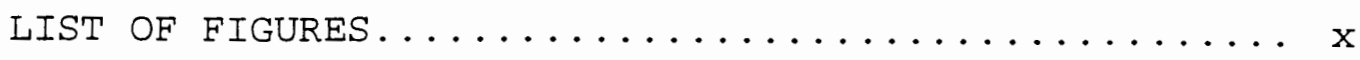

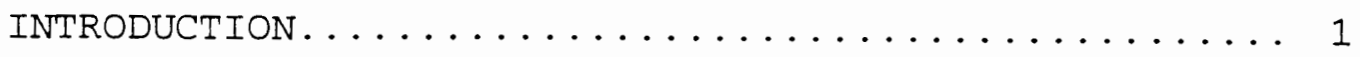

Goal of the study................... 5

Geologic Background - Regional Neotectonics.... 5

Recent Neotectonics Studies............... 11

Thesis study Area.................... 17

METHODS ................................. 19

RESULTS .............................. 30

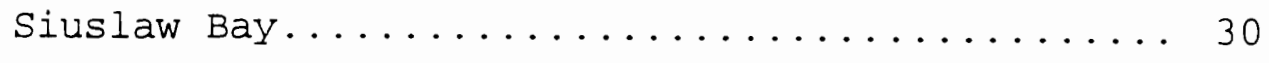

Core Location - General Description....... 30

Core stratigraphy and Radiocarbon Dates.... 34

Diatom Analysis..................46

Lower Umpqua River Area................ 50

Core Location - General Description....... 50

Core Stratigraphy and Radiocarbon Dates.... 53

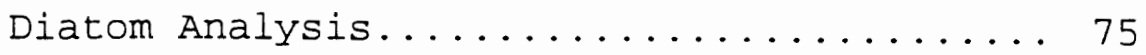

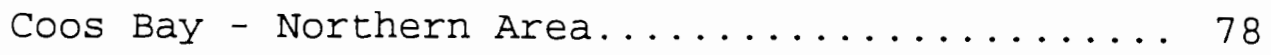

Core Location - General Description....... 78

Core Stratigraphy and Radiocarbon Dates... 81 
Coos Bay - Southern Area.................. 98

Core Location - General Description.......998

Core stratigraphy and Radiocarbon Dates.... 99

Coos Bay Area Diatom Analysis............. 137

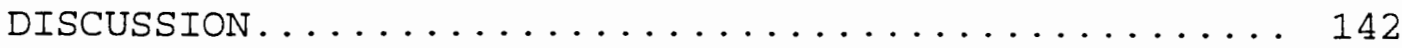

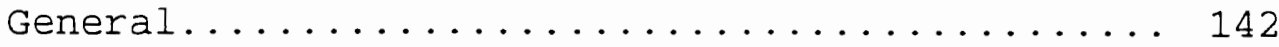

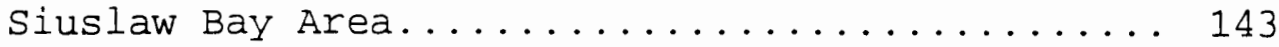

Lower Umpqua River Area................... 152

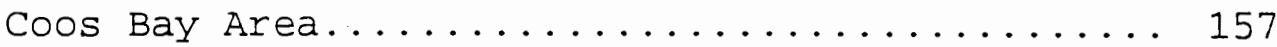

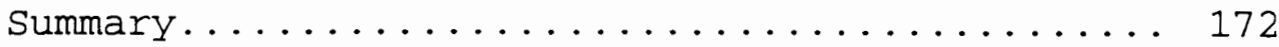

CONCLUSIONS ....................... 177

RECOMMENDATIONS ..................... 178

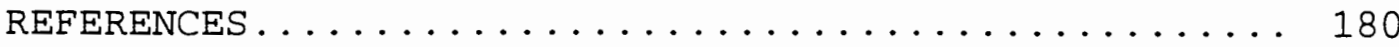

APPENDICES

A. Field Data Core Logs.................. 186

B. Core Top Elevations Referenced to MSL....... 246

C. C-14 Dating Analyses from Beta Analytic..... 249 


\section{LIST OF TABLES}

TABLE

PAGE

I Criteria for Visual Estimation of Peat

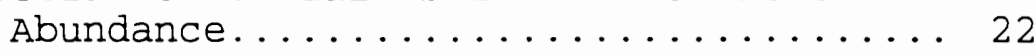

II Study Area Radiocarbon Dated Core List.... 22

II Marker Species Assemblage for Marine/Brackish Water Diatoms....... 28

IV Summary of Siuslaw C-14 Dates.......... 46

V Siuslaw Marine/Brackish Diatom Sampling counts.................... 48

VI Summary of Umpqua River Area C-14 Dates... 75

VII Umpqua Marine/Brackish Diatom Sampling

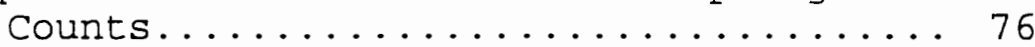

VIII Summary of Coos Bay C-14 Dates.......... 136

IX Coos Bay Marine/Brackish Diatom Sampling

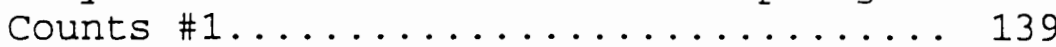

X Coos Bay Marine/Brackish Diatom Sampling counts $\# 2 \ldots \ldots \ldots \ldots \ldots \ldots 141$

XI Siuslaw Marine/Brackish (M/B) Diatom Assemblage - Summary of Core $216 \ldots \ldots 150$

XII Umpqua (West to East) - Core Transitional

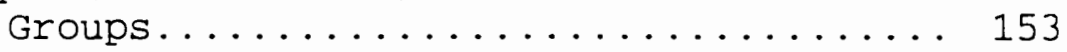

XIII Umpqua Area Candidate Tsunami Layers...... 154

XIV Umpqua Marine/Brackish (M/B) Diatom Assemblage - Summary of Core $332 \ldots \ldots 156$

XV Comparative Radiocarbon Dates Across the Whole Study Area................... 165

XVI Coos Bay Area Candidate Tsunami Layers.... 167

XVII Coos Bay Recurrence Intervals.......... 167

XVIII Northern Coos Bay Area Marine/Brackish (M/B) Diatom Assemblage - Summary of Cores 449 and $450 \ldots \ldots \ldots \ldots \ldots 168$ 
XIX Southern Coos Bay Area Marine/Brackish

(M/B) Diatom Assemblage - Summary of

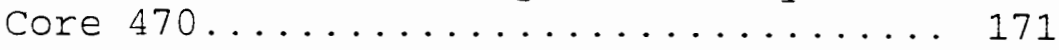

XX Study Area Recurrence Intervals......... 173 


\section{LIST OF FIGURES}

FIGURE

PAGE

1 Map of Study Area on the South-central Oregon coast showing coastline in in relation to the Cascadia Margin

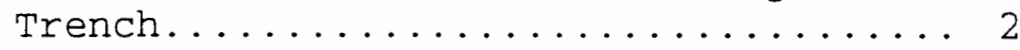

2 Hypothetical location of zero-isobase in which predicted areas of subsidence would lie east of the zero-isobase with seismic strain model inset....... 4

3 Regional map showing bay locations of prior coastal subsidence studies in Washington and oregon............ 12

4 Core subsampling for determining the presence of marine and freshwater

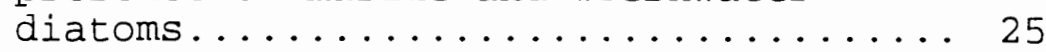

5 Siuslaw core location map............ 31

6 Siuslaw area radiocarbon dated cores..... 32

7 Siuslaw C-14 dated cores - site map...... 33

8 Umpqua River core location map......... 51

9 Umpqua area radiocarbon dated cores...... 52

10 Umpqua River C-14 dated cores - site map... 54

11 Drawing of an injection (Iiquefaction) feature found in scholfield creek

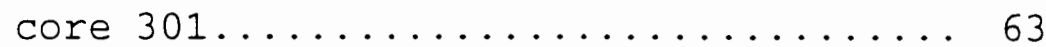

12 Coos Bay area core location map ......... 79

13 Coos Bay study area C-14 dated cores site $\operatorname{map} \ldots \ldots \ldots \ldots \ldots \ldots$

14 Coos Bay (Northern area) radiocarbon

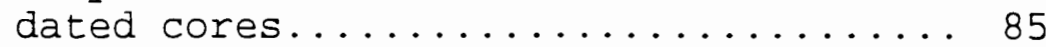

15 Coos Bay (Southern area) radiocarbon

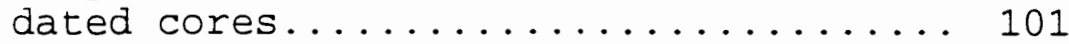


16 Photograph showing the Eive distinct episodically buried peats of core 470 from Pony Slough, Coos Bay, oregon..... 117

17 Composite core location map of coastal

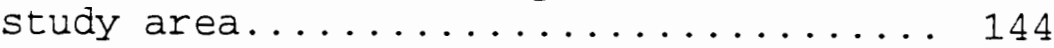

18 Inferred faults within the Pony Slough synclinal basin................ 161

19 Landward extent map of the zero-isobase determined by buried marsh

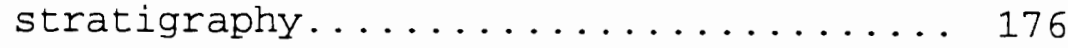




\section{INTRODUCTION}

The potential for megathrust earthquakes along the Pacific Northwest coastline (figure 1), which lies at the boundary between the North American plate and the subducting Juan de Fuca plate, continues to be a topic of major controversy. Although megathrust earthquakes associated with subduction zones along the coasts of Chile, Japan, and southeastern Alaska have been recorded in historic times (Heaton and Hartzell, 1987), there is no record, at least according to white European settlers, of a subduction zone earthquake along the central part of the Cascadia margin during the last 200 years.

Coastal uplift or subsidence were associated with historic dislocation events of the subduction zones of Chile, Japan, and Alaska (Heaton and Hartzell, 1987). Recent work has revealed evidence of episodically subsided and uplifted tidal marsh horizons along the coasts of Washington (Atwater, 1991 ) and northern Oregon (Grant et al., 1989; Peterson and Darienzo,1992). These records of abrupt coastal subsidence and uplift strongly support arguments for seismic activity in the Holocene. Late Holocene marine mud and peaty horizons associated with subsidence events have also been recorded in Humbolt Bay of northern California (Carver, 1991).

The subsidence events recorded in northern oregon by Peterson and Darienzo (1992) also suggest that the zero- 


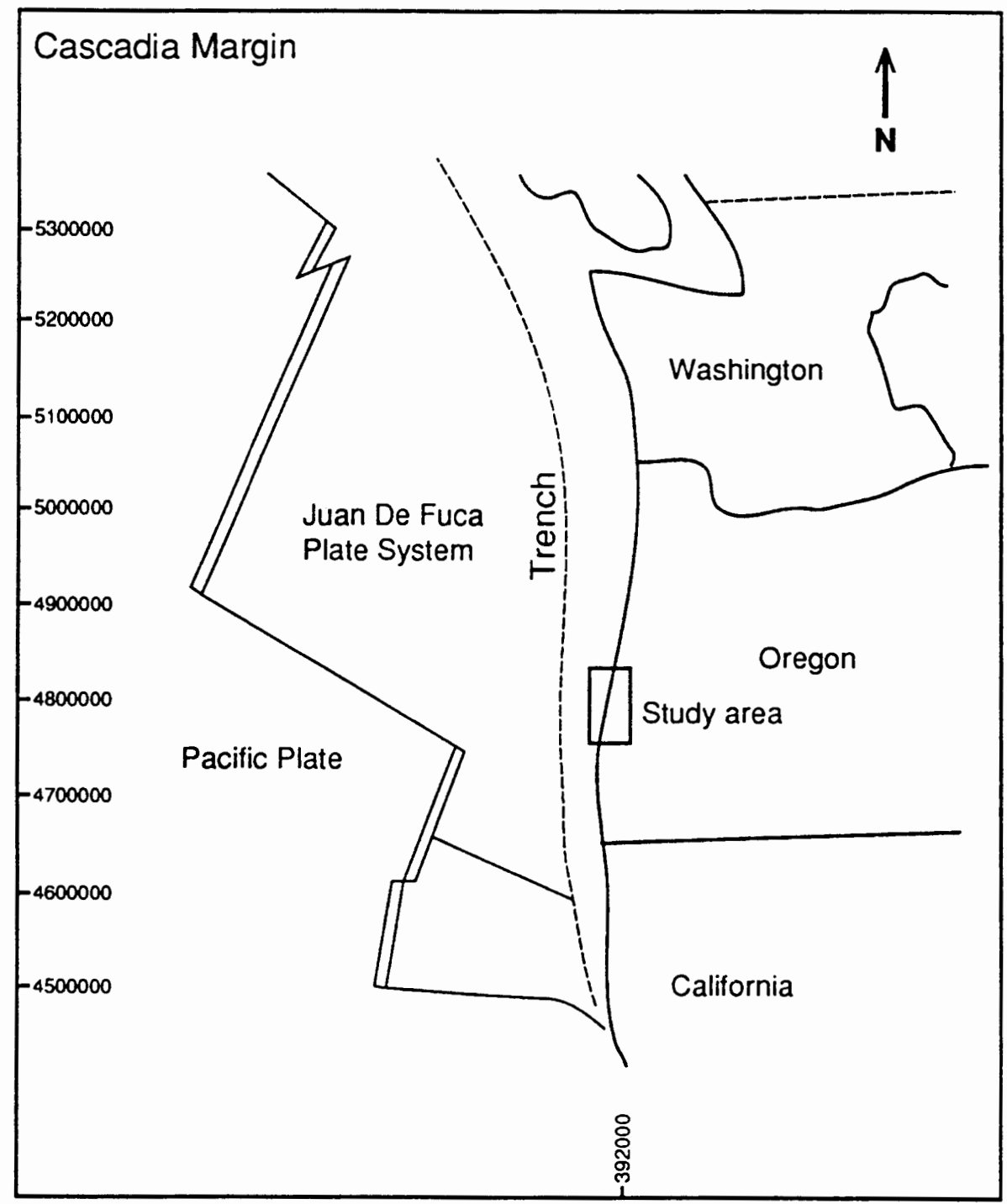

Figure 1. Study area south-central Oregon coast (rectangle). The coastline is indicated by a solid line and the Cascadia Margin trench is indicated by the dashed line. UTM coordinates on left border are meters north of the equator (i.e. $4800000 \mathrm{mN}$ and $392000 \mathrm{mE}$ ). 
isobase (the boundary between the zones of uplift and subsidence where no vertical movement cccurs) is located off the shore of the northern Oregon coast. More recent work by Briggs and Peterson (1992) on late Holocene marshes in the central Oregon coast has indicated a potential crossing of the upper plate zero-isobase of coseismic flexure in southcentral oregon (figure 2). This research suggests a possible zero-isobase intersection with the Oregon coastline near the Siuslaw River. Predictive dislocation fit models created by Hyndman and Wang (1993) suggest that the zero-isobase should be 90-100 $\mathrm{km}$ from the trench in the central Cascadia margin. This model would tentatively place the upper plate zeroisobase on-shore in the Florence/Siuslaw River mouth area of the south-central oregon coast.

This thesis focuses on specific tests of the possible on-shore crossing of the late Holocene zero-isobase in central oregon. The study area includes the coastal wetlands of the southern Oregon coast from Lily Lake (UTM4883000 mN.) south to the coos River (UTM4800000 mN.) (figure 1 ).

The research presented here includes the analysis of marsh cores taken from within the tidal zones of the Siuslaw, Umpqua, and coos River systems. These cores were analyzed for lithostratigraphy, paleotidal indicators, microfossil paleotidal indicators and radiocarbon age. The results of these analyses do support a zero-isobase crossing at about 90 


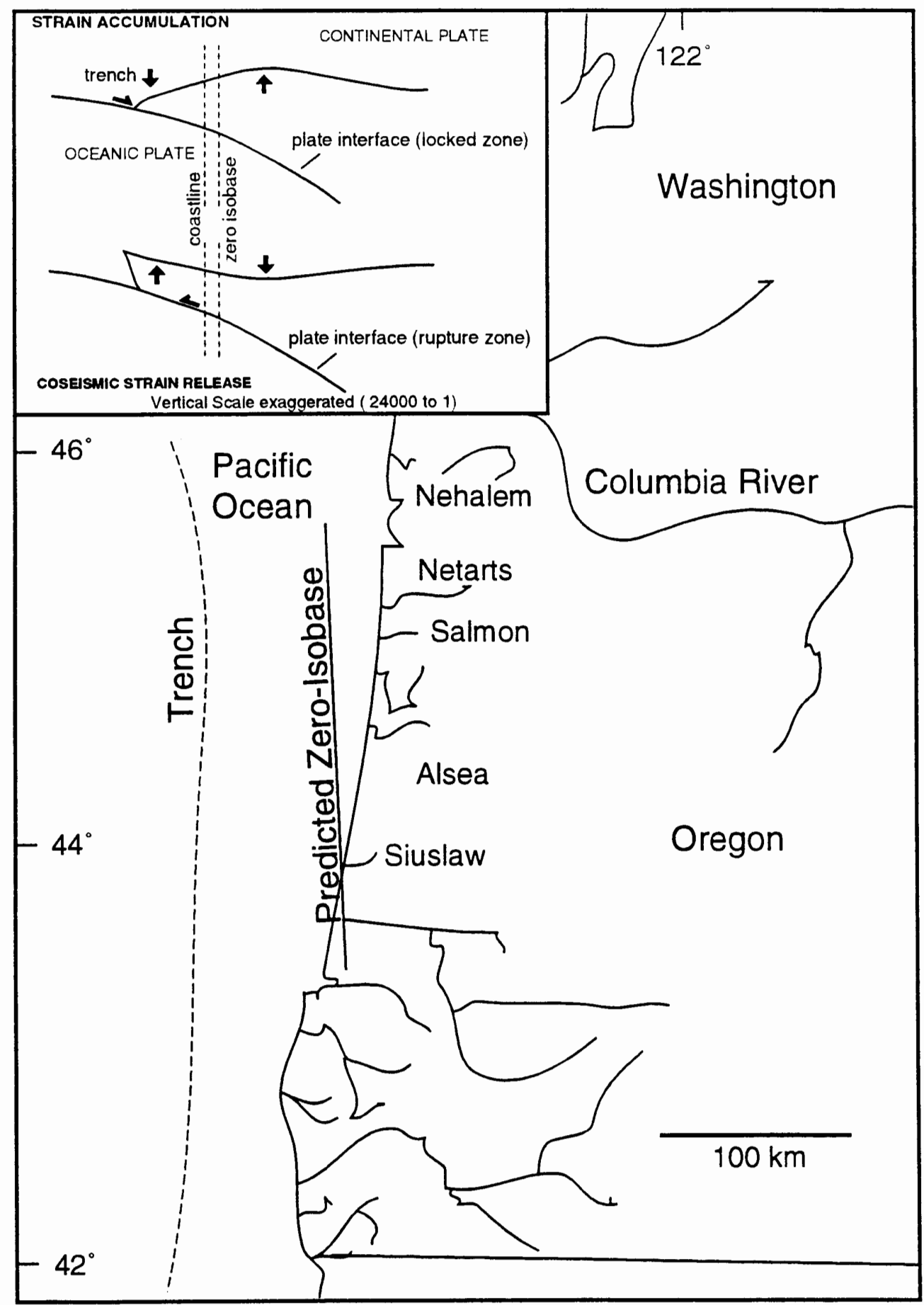

Figure 2. Hypothetical location of zero-isobase in which predicted areas of subsidence would lie east of the zero-isobase. Inset shows crosssectional view of continental plate response to interseismic strain accumulation followed by coseismic strain release (after Peterson and Darienzo, 1990). 
$\mathrm{km}$ from the trench in central Oregon.

Goal of The Study

The goal of this research is to establish the geometry and paleoseismicity of the central cascadia subduction zone as recorded in coastal deposits. This investigation tests the apparent coastal crossing of the late Holocene zeroisobase of elastic strain in the south-central area of the oregon coast. Testing this position involves analyzing core data from three areas: the Siuslaw, Umpqua, and coos Bay areas.

The identification of the zero-isobase is of critical importance to earthquake hazard analysts for defining the width of the locked zone and determining the potential magnitude of future earthquakes. Additionally, this work should provide a crucial linkage between the neotectonics of northern and southern oregon.

Geologic Background

Regional Neotectonics

The tectonic history of the Pacific Northwest is the product of convergence between the North American plate and the subducting Juan de Fuca plate. Off the coast of western North America the oceanic crust has formed by spreading between the Pacific plate and the Farallon plate. The 
Faralion plate has been subducting under the North American plate Eor the last 150 million years and its remnant, the Juan de Fuca plate continues this process forming the Cascacia subduction zone. The existence of the subduction zone was first defined by T. Atwater (1970) and later by Riddihough (1980). Their analyses are based on magnetic anomalies in the seafloor, providing a record of spreading and relative plate movement. While data from magnetic anomalies have been crucial in understanding the tectonic history of the Pacific Northwest it cannot accurately determine the most recent plate motion for the past 500,000 years. Abrupt changes in the shape of the Juan de Fuca plate as well as abrupt movements of the plate's pole of rotation makes the definition of recent tectonic activity uncertain on the basis of magnetic anomalies. The subduction process has been occurring for at least 40 million years and continues to occur in the present (Atwater, 1970; Riddihough, 1982). Additional work by Riddihough (1984) has indicated that over the last 6.5 my the Juan de Fuca plate system has been slowing and fragmenting as it progresses in a northeasterly direction.

While there is little debate as to the existence of the subduction zone, questions are being raised as to the current nature of the plate convergence. For example, is the margin locked, or alternately is the subduction process aseismic? Can the historic (200 year) silence of the subduction zone be 
explained by very long intervals between episodic dislocations of the megathrust?

Heaton and Kanamori (1984) and Heaton and Hartzell (1987) have concluded that the Cascadia subduction zone exhibits the classic features typical of other episodically locked subduction zones, including those of Chile, Japan, and Alaska, where large subduction zone earthquakes have occurred. They compared the physical characteristics of the Cascadia subduction zone with other subduction zones and found that the Cascadia differs substantially from the Mariana type aseismic zones (uncoupled) but strongly resembles the seismically active chilean type zone (strongly coupled).

An important similarity between strongly coupled subduction zones is a youthful oceanic lithosphere. Heaton and Hartzell (1987) found the lithosphere of the Cascadia subduction zone to be only 10 million years old. They also discovered two other features of a youthful oceanic lithosphere. The seafloor adjacent to the continental margin is only $3 \mathrm{~km}$ deep and the average heat flow is high. The subduction of a young and somewhat buoyant oceanic lithosphere results in strong frictional coupling with the overriding continental lithosphere, as seen along much of the North and South American coastlines (Chilean type). In contrast, Mariana (aseismic) type subduction zones are characterized by the subduction of an old, dense lithosphere 
with oceanward retreat of the trench and the opening of back-arc basins.

Ando and Balazs (1979) have questioned whether the lack of great subduction zone earthquakes in the cascadia margin represents aseismic subduction rather than preseismic strain accumulation. They have suggested that the subduction is occurring as creep on the interface between the two opposing plates, and therefore does not allow for a large build-up of strain. These conclusions are based the assumptions (1) that the crustal deformation seen in western washington is primarily related to offshore subduction and (2) a lack of historic megathrust seismicity.

Work by Crosson (1983) in the Puget Sound area provided evidence of a Benioff zone in the Juan de Fuca plate characteristic of a locked subduction zone. Crosson determined that the zone dips eastward at approximately 10-12 degrees based on a concentration of intraplate seismicity in the subducting slab (Crosson, 1983).

Analyses of Geodolite surveys in the Seattle area, combined with triangulation surveys in the straits of Juan de Fuca, and numerous leveling surveys along the Pacific Northwest coast, have demonstrated evidence of accumulating elastic strain (Savage and Lisowski, 1981). The conclusions of Savage and Lisowski can be explained by a model in which the shallow thrust zone is locked between the trench and the coastal region (Savage and Lisowski, 1991). 
Marine terraces provide an inaication of coastal uplift indicative of long-term strain accumulation. For example, uplift rates of 3-4 mm/year are reported for 80,000 year old terraces in southern Oregon. The marine terraces along the northern Oregon coast lack the high rates of deformation that are found along the southern Oregon coast (Muhs, 1990). The disparities in the degree of deformation between these areas can be explained by the proximity of the trench to the coastline in the southern coastal region (Mulder, 1992). Evidence for coastal subsidence within marine terrace sediments indicated by vegetation buried by bay sediments and changes in sediment grain size was found by Mulder (1992) on the oregon coast. The results of Mulder's research may be explained by periods of tectonic stress accumulation causing uplift which is immediately followed by strain release causing subsidence during late Pleistocene time (Mulder, 1992).

The first geologic evidence for subduction zone earthquakes in the Cascadia Margin was discovered by Atwater (1987) in the buried marsh deposits found in tidal bays in Washington. Peat layers which have abrupt upper contacts with layers of tidal flat muds may represent the rapid burial of coastal lowland vegetation as a result of coseismic coastal subsidence (Peterson and Darienzo, 1992). The appearance of episodically buried soils is the primary 
evidence implying uplift and subsidence characteristic of great subduction zone earthquakes (Atwater, 1992).

In addition to the record of buried peats, some anomalous sand layers that cap buried marshes may provide evidence of past megathrust events which produced tsunamis. A marine surge such as a tsunami, should produce a sand deposit which thins with distance landward. Such evidence of widespread tsunami inundation has been found along the Washington and Oregon coasts (Atwater, 1992 and Peterson and Darienzo, 1992).

Goldfinger (1992) contends that the observed Holocene subsidence events may, at least partly, represent the development of synclines that trend obliquely to the continental margin. He suggests that their growth may be triggered by megathrust events .

Correlation of coastal buried peaty horizons from the southern oregon coast is complicated by the complex local fault and fold structures alluded to by Goldfinger (1992). Clarke and Carver (1992) have recorded active local fault and fold structures along the northern most California coast. Peterson and Darienzo (1989) reported that such local structures were also active in Holocene time along the southern Oregon coast. 
Recent Neotectonic Studies

Atwater (1987) first noted evidence of late Holocene coastal subsidence in his reports on coastal wetland stratigraphy of the southwestern washington coast. There he found sequences of buried forested wetlands and bay muds in coastal lowland sites. He found that the Columbia River, Willapa Bay, Gray's Harbor, and Copalis River estuaries (figure 3) of Washington's outer coast contain late Holocene deposits consisting of peaty layers alternating with intertidal mud layers. Tree ring and precise radiocarbon correlation of the last subsidence event (about 300 calendar years ago) at these sites has led Atwater (1987) to conclude that only rapid tectonic subsidence can account for the nature of the buried wetland sequences that he observed. He suggests that tsunamis followed at least three subsidence events, producing thin sandy layers found above the peats at three buried lowland sites. The sandy layers at Willapa Bay become progressively thinner and finer grained with distance landward, characteristic of tsunami inundation and sedimentation.

Atwater (1987) further suggests that tectonic subsidence caused by a great subduction zone earthquakes could explain the differences between the long-term $(0.5 \mathrm{~mm} / \mathrm{yr})$ and shortterm $(2-3 \mathrm{~mm} / \mathrm{yr})$ rates of uplift seen on the outer washington 


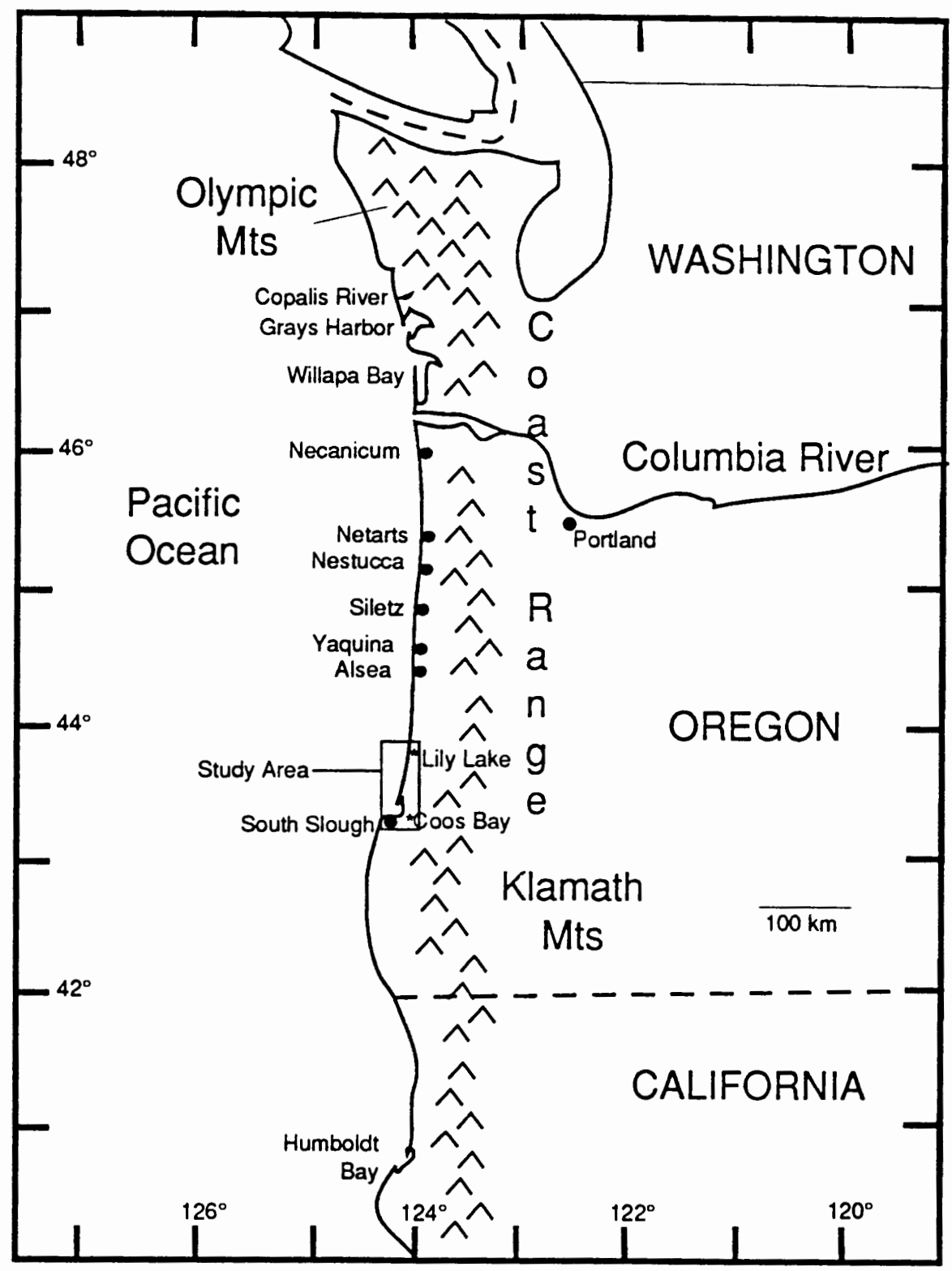

Figure 3. Regional map showing bay locations (black dots) of prior coastal subsidence studies done in southwestern Washington by Atwater (1987), and six bays on the northern Oregon coast by Darienzo and Peterson in 1990 (after Darienzo, 1991). 
coast. That is to say that modern uplift rates reflect episodic interseismic strain accumulation.

Reconnaissance studies of late Holocene buried marshes have been completed in six bays on the northern oregon coast (Darienzo and Peterson, 1990; Peterson and Darienzo, 1992; and Darienzo, 1991). Subsidence records in cores and cutbanks tentatively correlate five of the last six events (300 to 2600 RCYBP) in the Necanicum-Neawanna, Netarts, Nestucca, Siletz, Yaquina, and Alsea Bays (figure 3). of these, the events recorded at several sites may also correlate with sites studied by Atwater in southern Washington (Darienzo, 1991). Based on the evidence of buried peat sequences Peterson and Darienzo (1992) have calculated the average recurrence interval at approximately 400 years, a period which is substantially shorter than that predicted by other researchers (500-600 yrs; Adams, 1990). At least one dislocation recorded on the northern oregon coast apparently did not rupture across the full length of the Cascadia margin (Darienzo, 1991; Peterson et al.; 1993). This rupture at about 800 RCYBP did not extend north of Yaquina Bay. Research by Peterson and Darienzo (1989) and Peterson and Briggs (1992) has led to the possible identification of the landward termination of the coastal fold and fault belt in Oregon at approximately 90-120 km from the trench. Their predictions of the landward termination of these deformation structures were based on the distinct variations they found 
in the geomorphology of the drainage systems along the southcentral oregon coast. The regional variations displayed in late pleistocene marine terraces along Pacific Northwest coast (Mulder, 1992) as well as recent mapping by Goldfinger (1992) of offshore folds and faults along the northern oregon coast also support the predicted landward attenuation of this upper plate deformation, at some $100 \mathrm{~km}$ from the trench. Map compilations by Black and Madin (1993) support the landward termination of the onshore fold/fault belt in southcentral oregon. The results of new geologic mapping and the compilation of structure data from previously mapped Tertiary bedrock show that the onshore fold belt terminates $100-110 \mathrm{~km}$ from the trench near Catching Slough in Coos Bay (Black, 1993).

Nelson (1992) has studied evidence of buried tidal and wetland soils in the south slough of coos Bay and attributes their existence to several possible scenarios. They may be evidence of subsidence caused by a great earthquake within the Cascadia subduction zone or, he contends, these buried peats may be caused by the fault and fold system which resulted from a great earthquake. Nelson surmises that some buried peats may have been caused by changes in tide levels of a nontectonic origin. He bases this conclusion on the similarity he found between the lithologies and stratigraphy of the buried marshes of the Pacific Northwest with similar 
intertidal deposits in eastern England and western Scotland (Nelson, 1992).

Data from seismic reflection, SeamARC-1A sidescan sonar and SeaBeam bathymetry analyzed by Goldfinger (1992) have revealed a set of at least three west-northwest trending left lateral strike-slip faults intersecting the Cascadia subduction zone. These faults apparently cut both the overriding North American plate and the subducting Juan de Fuca plate. The late Pleistocene and Holocene sediments of the upper continental slope are deformed by folds which trend west-northwest. Several active synclines in the outer continental shelf project toward the coastal bays. Goldfinger (1992) suggests an alternative mechanism, other than a megathrust event, to explain the record of coastal submergence in these bays. He contends that the marsh and coastal lowland subsidence observed on the northern Oregon coast might not be related to regions of elastic strain on the megathrust, but instead it reflects the growth of local synclines. He further suggests that a significant amount of the strain accumulating at the margin is accommodated by the shortening of the forearc region of north and central oregon by clockwise tectonic rotation (Goldfinger et al., 1992). This could substantially lengthen the predicted recurrence intervals of a great earthquakes.

Kelsey (1990), working in the Cape Blanco area of the southern Oregon coast has found late Quaternary wave cut 
platforms ana deposits which show evidence of uplift, folding and faulting. These include five late Quaternary marine terraces and one possible uplifted Holocene beach berm. This beach berm, which is $19 \mathrm{~m}$ above present sealevel, has also been interpreted by Kelsey to be a tsunami deposit (Kelsey 1990).

He explains the marine terraces as an onshore expression of the WNW trending fault belt on the continental shelf which was noted by Goldfinger (1992). Kelsey's observations support the evidence of the fold belt appearing on land along the south-central coast at Cape Arago (Peterson and Darienzo, $1989)$.

Paleoseismic studies by Clarke and Carver (1992) in the Humbolt Bay area of the northern California coast have revealed evidence of Holocene coseismic subsidence from sequences of buried marshes and forests found at sites at the north margin of the bay. These sites show evidence of buried soils containing the rooted stumps of ancient Sitka spruce. Intertidal mud horizons seen there lie directly above the subsided peaty horizons. Near the axis of the Freshwater syncline at Mad River Slough four to five Holocene stacked buried peaty sequences were found. The upper three have been produced in the last 1600 radiocarbon years. The average recurrence interval of these buried events is 400-450 years. They are relatively similar to those found in bays and estuaries of the southern washington coast by Atwater (1987) 
and to those reported by Peterson and Darienzo (1989) in the bays of the northern oregon coast. However, unlike the Washington and northern Oregon buried peats, these deposits are restricted to a local tectonic structure near the Mad River mouth.

Clarke and Carver (1992) also found evidence of late Holocene uplift in the lower Clam Beach marine terrace. The terrace consists of sediments of pebbly sand overlaid by two eolian dune sequences. Whereas, the seafloor is the only possible source for the sands in the area, their elevation suggests that sudden uplift raised the seafloor (Clarke and Carver, 1992).

The stratigraphy in the Humbolt Bay area shows evidence of sudden slip of at least $3.5 \mathrm{~m}$ in two large thrust fault systems. Correlation of carbon-14 dating indicates that the evidence of faulting, uplift and subsidence noted above all occurred roughly synchronously (Clarke and carver, 1992) suggesting the potential for triggering by a large megathrust event.

Thesis Study Area

The study area is a $83 \mathrm{~km}$ long section of coastline on the south-central oregon coast, extending from Lily Lake (UTM $4883000 \mathrm{~m} \mathrm{~N}$ ) south to the coos River (UTM $4800000 \mathrm{~m} \mathrm{~N}$ ) The study area roughly extends inland $20 \mathrm{~km}$ from the coast 
(figure 3). It comprises three zidal bay systems, the Siuslaw, Umpqua, and Coos River systems.

The coastline in this area trends south-southwest. The coastline of the study area is $90-110 \mathrm{~km}$ from the Cascadia margin and trends obliquely to the margin reaching a minimum distance from the margin of $60 \mathrm{~km}$ at Cape Blanco, just south of the study area.

This area is characterized by upper plate deformation consisting of folding and/or reverse and high-angle thrust faulting. Research by Peterson and Darienzo (1989) and Kelsey (1990) shows evidence of substantial late Quaternary folding 80-100 km from the trench along the southern Oregon coast. As mentioned previously, Black and Madin (1993) have confirmed the landward termination of the onshore fold belt at 100-110 km from the trench near Catching slough in coos Bay. At approximately 100-120 km from the trench, upper plate deformation abruptly decreases in amplitude as indicated by Newton's (1980) recording of structure data along west-east traverses in this area. Peterson and Briggs (1992) have interpreted this zone of decreasing vertical deformation as the landward termination of the megathrust locked zone.

This boundaries of this study area were chosen to encompass the predicted onshore crossing of the late Holocene zero-isobase and the landward extent of the coastal fault and fold belt in south-central oregon. 


\section{METHODS}

Coastal wetlands from Floras Lake (UTM $4748000 \mathrm{mN}$.) to Lily Lake (UTM $4883000 \mathrm{mN}$.) were investigated for evidence of episodically buried peats by reconnaissance coring. of the 154 reconnaissance cores taken, 141 were taken in the Siuslaw, Umpqua, and coos River systems. Core sampling in these bays extended inland approximately $20 \mathrm{~km}$ from the ocean.

Core stratigraphies and ${ }^{14} \mathrm{C}$ dates of the buried peats should help constrain regional models of coseismic subsidence or uplift including relative recurrence intervals and location of the zero-isobase, i.e. locations of continuous peat development in late Holocene time.

Topographic maps and aerial photographs were used to identify and confine the extent of the study area and to locate initial reconnaissance core sites in representative tidal marshes.

These sites were selected according to the following criteria: 1) areas of extensive marsh, 2) lack of apparent tidal-creek cuts, 3) suitable distance from valley sides, 4) suitable distance (tidally influenced) up in the bays from the coast, and 5) location in mapped geologic structures such as synclines, etc... 
Both gouge cores $(2.5 \mathrm{~cm}$ diameter) and vibra-cores $(7 \mathrm{~cm}$ diameter) were used to obtain the marsh deposit cores. Depth of gouge coring was 2 to $5 \mathrm{~m}$ below the surface. The depth of vibra-coring was restricted to $3 \mathrm{~m}$ or less. Continuous vibracores were obtained by driving a $7 \mathrm{~cm}$ aluminum pipe into the ground and then using a winch-out tool to pull it out. Gouge cores were taken at all the vibra-core sites in order to account for any soil compressing or rodding. Rodding caused by the vibra-core results from wood clogging the end of the vibra-core tube, thereby pushing away softer material and decreasing the amount of material obtained.

Many of the core elevation tops at each site were surveyed into mean tidal level using an electronic total station (EDM/theodolite). The mean tidal datums in each of the three bays were estimated on the basis of indicated tidal data taken from NOAA tidal tables. Core top elevations were established in order to provide an elevation reference point for core sites within each bay.

Gouge cores were logged at the field site and visually examined for (1) relative abundance of organics (peats) and inorganics (siliclastic material), (2) macrofossils (spruce tree roots, Triglochin rhizomes, woody fragments), (3) contact relationships, and (4) sediment grain size. Vibracores were taken to the Oregon Institute of Marine Biology in Charleston, Oregon where they were split, logged, and stored 
in a cooler prior to transport to freezers in the PSU Geology Department core lab.

Cores were examined for evidence of rapid changes in the depositional environment that are indicative of coseismic subsidence, uplift, or gradual submergence. Evidence of abrupt subsidence was defined as a sharp contact $(<0.5 \mathrm{~cm}$ ) between peat and overlying sandy or muddy deposits. Gradual contacts (>0.5 cm) between peats and underlying muds were also documented. Evidence of uplift was defined as sharp or gradual contacts between intertidal deposits and overlying high marsh peats or spruce forest soils that occur above the reach of high tides.

Peaty organics are defined as materials which visually appear as distinctly fibrous, matted and/or spongy material containing some vertical roots or rhizomes indicating in-situ growth, as opposed to flat lying detrital organics. Visual estimates of organic material abundance have been related to relative marsh development (high marsh-colonizing marsh-mud flat) (Darienzo, 1991, Peterson and Darienzo, 1992). Core samples in the study were also compared to known marsh setting and tidal elevations. Peat abundance was estimated by visual examination of split core surfaces using the criteria in TABLE I.

Forty-five (45) bulk samples and one (1) Accelerator Mass Spectrometer (AMS) sample from nineteen (19) core sites were taken for radiocarbon dating (TABLE II). 
TABLE I

CRITERIA FOR VISUAL ESTIMATION OF PEAT ABUNDANCE

LITHOLOGY

Peat

Muddy Peat

Peaty Mud

Slightly Rooted Mud

Mud
\% ORGANICS

$>80 \%$

$50-80 \%$

$10-50 \%$

$5-10 \%$

$<5$ 웅
MARSH/TIDAL LEVEL

very high marsh or forest: supratidal

high marsh : upper intertidal

high-low marsh:, intertidal

colonizing marsh: intertidal

barren tidal flat: low intertidal

TABLE II

RADIOCARBON DATED CORE LIST

$\underline{A R E A}$

Siuslaw

Umpqua

Coos Bay
CORE NUMBERS

$213,216,222,225$

$301,311,321,328,332,337,339$

$408,448,449,462,465,470,476,478$ 
In preparation for radiocarbon dating of peat and/or woody materials, the cores were subsampled from the top ten (10) centimeters of the buried peaty horizons. These samples were washed, sieved $(>0.062 \mathrm{~mm})$, dried, weighed, and packaged in foil. They were then sent to a commercial laboratory (Beta Analytic Inc.) for standard pre-treatment and bulk radiocarbon dating. Beta Analytic Inc. pre-treated the samples by dispersing them in hot acid to eliminate carbonates, repeatedly rinsing to neutrality, bringing them to dryness, and combusting them in a vacuum system. The woods were similarly pre-treated, with the addition of a hot alkali soaking to take out humic acids. The one AMS sample was also sent to Beta Analytic Inc. where it was given successive acid and alkali leachings to remove carbonates and humic acids. The sample was combusted in an enclosed system. The carbon dioxide collected was purified and reacted with the hydrogen on a cobalt catalyst to produce graphite. This was applied to a copper target. The AMS measurements were made in triplicate at the ETH (Eidgenossische Technische Hochschule) University in zurich. The chemical pretreatments and target material conversion were done at Beta Analytic Inc. The carbon 13 measurement was made in the accelerator itself. Selected cores were subsampled to determine the presence of marine and freshwater diatoms. In cores which had distinct sequences of buried peats, the subsamples were taken from the top $10 \mathrm{~cm}$ of each peaty layer and from the 
bottom $10 \mathrm{~cm}$ of each of the mud layers topping the peaty horizons (figure 4). Those cores containing continuous peats were subsampled at representative depths to compare with those cores with stacked sequences of peat and mud layers.

Methods of obtaining diatom samples from cores:

1.) Spatulas were used to extract mud and peat samples. Spatulas were washed after each sample was obtained. The samples were placed in plastic bottles, sealed, and labeled.

Method of cleaning diatoms:

1.) An approximately 1 cC sample (pea sized) was placed in a test tube containing a solution of $6 \mathrm{~N}$ concentrated hydrochloric acid ( $\mathrm{HCl}$ ) and the test tube was placed in a 400 mI beaker.

2.) The beaker was placed on a hotplate and the solution was boiled for 20 minutes to remove any organic material. 3.) After boiling the samples were left to stand for twenty four hours. Most of the liquid was decanted off and distilled water was added to the remaining solids which were then centrifuged.

4.) The same amount of $6 \mathrm{~N} \mathrm{HCl}$ was added to the sample remaining in the test tube and was brought back to boiling. Then $6 \mathrm{~N} \mathrm{HNO}_{3}$ was added drop by drop until the solution turned 


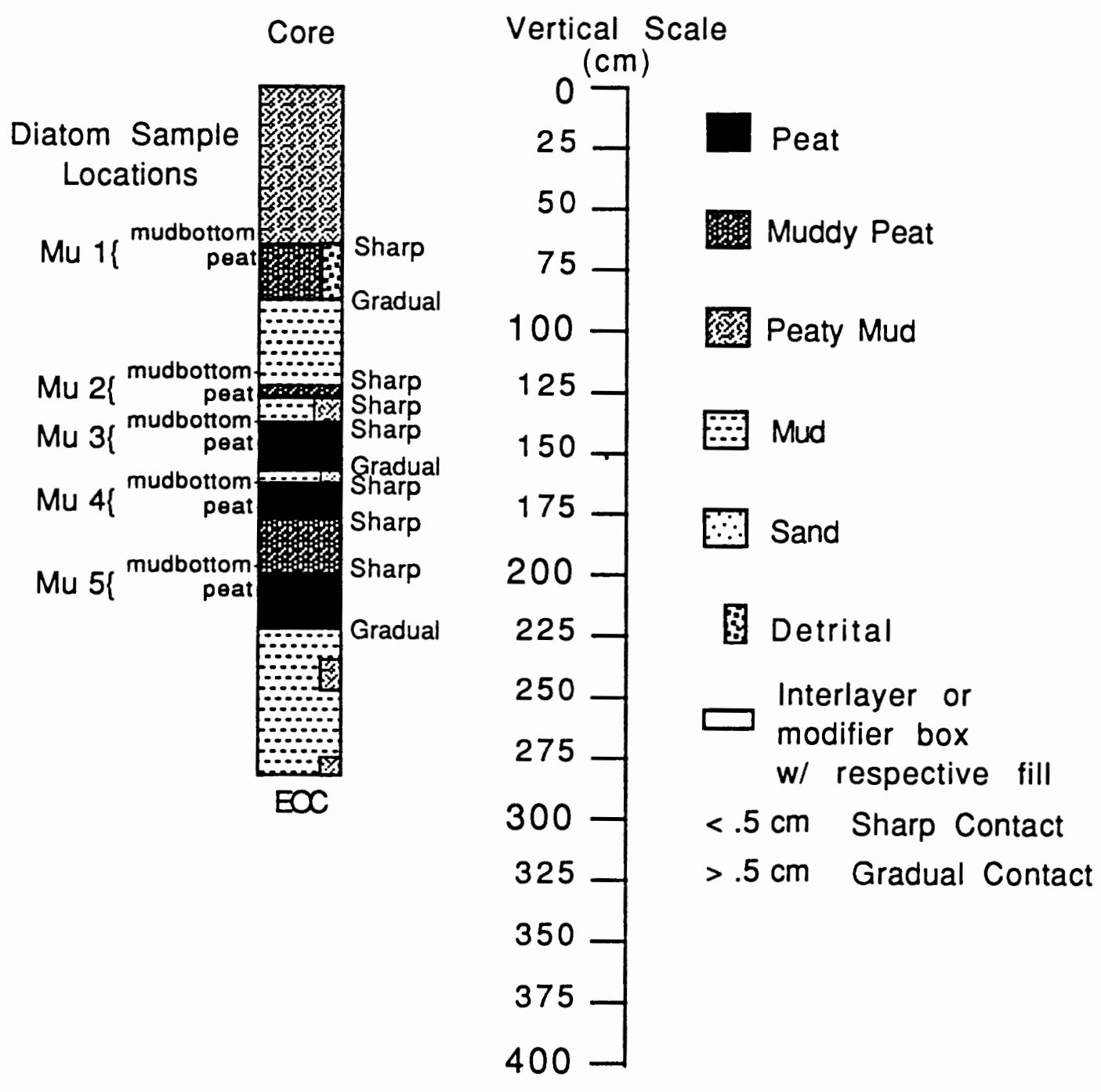

Figure 4. Core subsampling for determining the presence of marine and freshwater diatoms. Subsamples were taken from the top $10 \mathrm{~cm}$ of each peaty layer and from the bottom $10 \mathrm{~cm}$ of each mud layer. Buried marsh/forest units are keyed - Mu1, Mu2, Mu3, etc. 
a milky yellow, giving off a yellow-brown gas. The $\mathrm{HNO}_{3}$ was added until the gassing stopped.

5.) At this point all black organic material was removed, although this may not have occurred in a few samples.

6.) The beakers were covered, allowing the solution to cool and settle overnight.

7.) The final precipitate was placed in labeled glass bottles and approximately $15 \mathrm{ml}$ of distilled water was added to each bottle.

Method of making slides:

1.) The above bottles were agitated and a pipette was used to withdraw samples.

2.) One (1) drop of a sample was placed on a clean slide.

3.) Three (3) drops of distilled water was also placed on the slide.

4.) The slide was placed on a warming plate to dry for ten (10) minutes.

5.) When dry, the slide was removed from the plate and one (1) drop of Preservaslide mounting medium was dropped onto the slide with a glass rod. A clean cover slip was placed on top and gently pressed down with a clean glass rod; it was allowed to dry overnight.

6.) The finished slides were then cleaned with ivory soap. 
Method of scanning the slide:

1.) Each slide was scanned in horizontal grids from left to right, making eight (8) scans per slide. This was a visual observation during which diatoms were counted. Those diatoms identified as to species were identified by measurement of length and width, specific structure of frustules and the number of striae per $10 \mathrm{um}$.

2.) Taxonomy references used for identification are those listed in the "reference" section of this paper.

Specific marine and brackish water diatoms were used as marker species. The diatoms making up the assemblage were defined by scanning two representative slides from each bay area. Those marine/brackish water diatoms identified on these six slides became the assemblage against which all other slides were evaluated. A semi-quantitative analysis of only these marine/brackish water marker diatoms was made during scanning. Only whole frustules were counted. A count of five or fewer marine/brackish water diatoms was considered indicative of an environment in which salinity was $5 \%$ or less. Note that environmental factors other than salinity can affect diatom counts. These factors will be addressed in the Discussion section. Marker species included the following marine to brackish diatoms by genera, and species (TABLE III). 


\section{TABLE III}

MARKER SPECIES ASSEMBLAGE FOR MARINE/BRACKISH WATER DIATOMS

GENERE and SPECIE

Actinpzychus undulates

Coscinodiscus sp.

Stephanodiscus sp.

Trigonium sp.

Cocconeis sp.

Diploneis smithii

Diploneis interrupta

Nitzschia punctata

Opephora marina

Rhopalodia sp.

Surirella sp.

\section{SPECIES}

undulates

* curvatulus

* convexus

* I inetus

* sp.

* alternans

* $s p$.

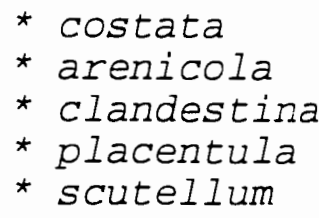

smithii

interrupta

punctata

marina

* musculus

* gibberula

* striatula

* fastuosa

* ovata

\section{REFERENCES}

2,3

$1,2,3$

2

2,3

1,4

1

1,2

2

2

$1,2,4,5$

$1,2,4$

$2,4,4,5$

$1,2,4,5$

2

1

2,5

4,5

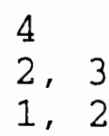

* Species (sp.) grouped as sum total within genera. 
Publication titles of plate references used for diatom identification (Eull reference information in thesis reference section):

1. Rao, V.N., J. Lewin, 1976. Benthic marine diatom flora of False Bay, San Juan Island, Washington.

2. Riznyk, R.z., 1973. Interstitial diatoms from two tidal flats in Yaquina Estuary, Oregon, USA.

3. Cupp, E.E., 1943. Marine plankton diatoms of the west coast of North America.

4. Weber, C.I., 197.1. A guide to the common diatoms at water pollution system stations.

5. Patrick, R., C.W. Reimer, 1966, 1975. The Diatoms of The United States, Vol. 1 and Vol. 2. 


\section{RESUITS}

\section{SIUSLAW BAY}

Core Locations:

Siuslaw Bay is located in the northern part (approximately UTM4872000 $\mathrm{mN}$ ) of the study area on the southcentral Oregon coast (figure 5). Twenty-five cores were taken in this locality. Of these, 5 cores $(213,216,220$, 222, and 225) were vibra/pound cores, the remaining 20 cores were gouge cores. The sites cored include tidal marshes on Siuslaw Bay, Siuslaw River, and tidally influenced tributary streamlets of the Siuslaw River up to a distance of $23 \mathrm{~km}$ due east of the ocean, i.e. to Hadsell Creek at Mapleton. Four cores were taken at Lily Lake, a perched back dune pond, located approximately $13 \mathrm{~km}(8 \mathrm{mi})$ north of Florence.

of the twenty-five cores taken from this area, four cores were subsampled for radiocarbon dating (figure 6). These were core 225 from Lily Lake, core 222 from Deming Creek, core 213 from Bernhardt Creek, and core 216 from Karnowsky Creek (figure 7 - Siuslaw C-14 core site map). Elevations for core sites were corrected to mean sea level and are recorded in Appendix B for future use in correlations. Field core logs which document core site marsh stratigraphic records are shown in Appendix A. 


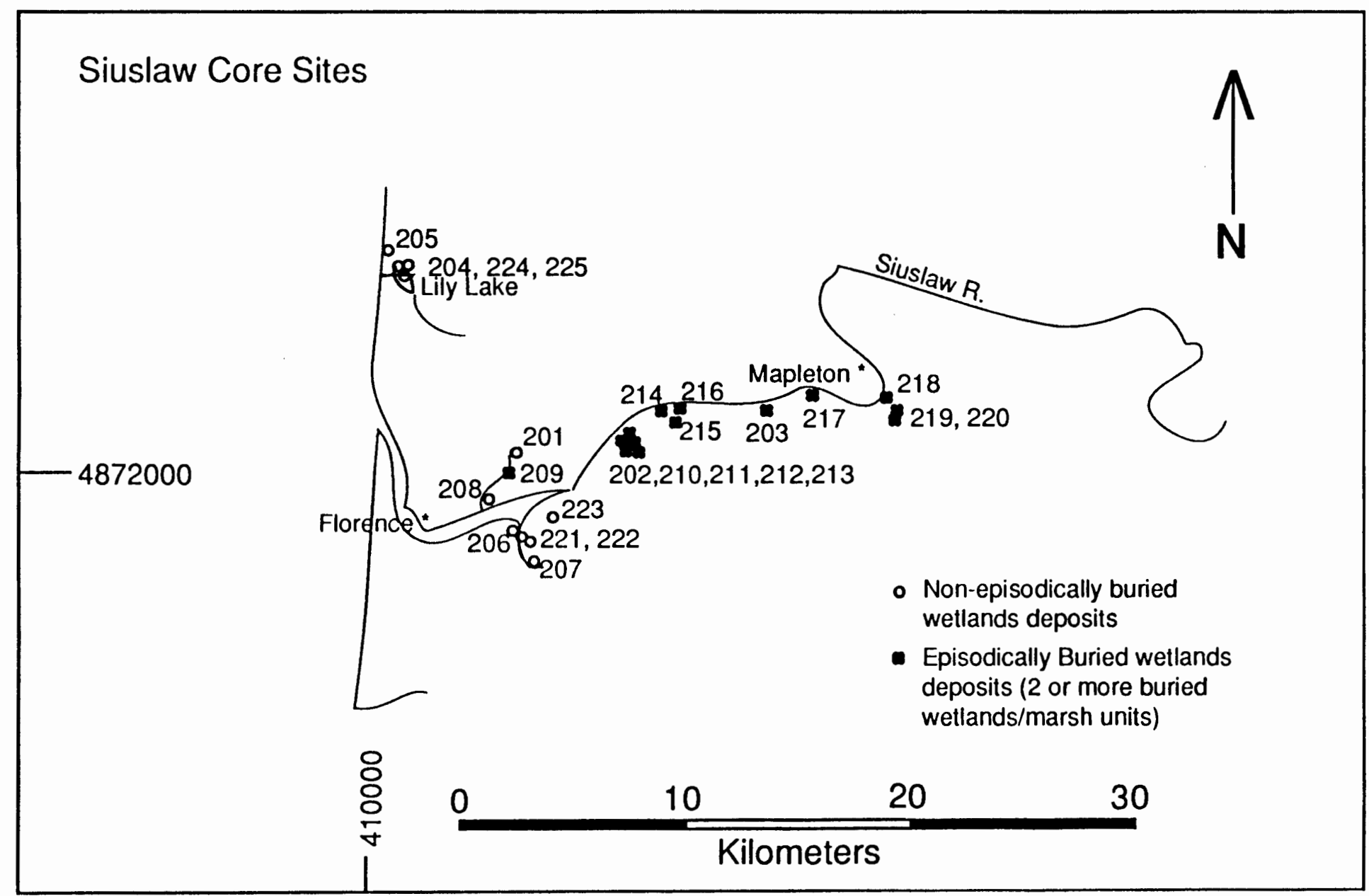

Figure 5. Siuslaw core location map. Sites included tidal marshes and tidally influenced tributary streamlets of the Siuslaw River. 


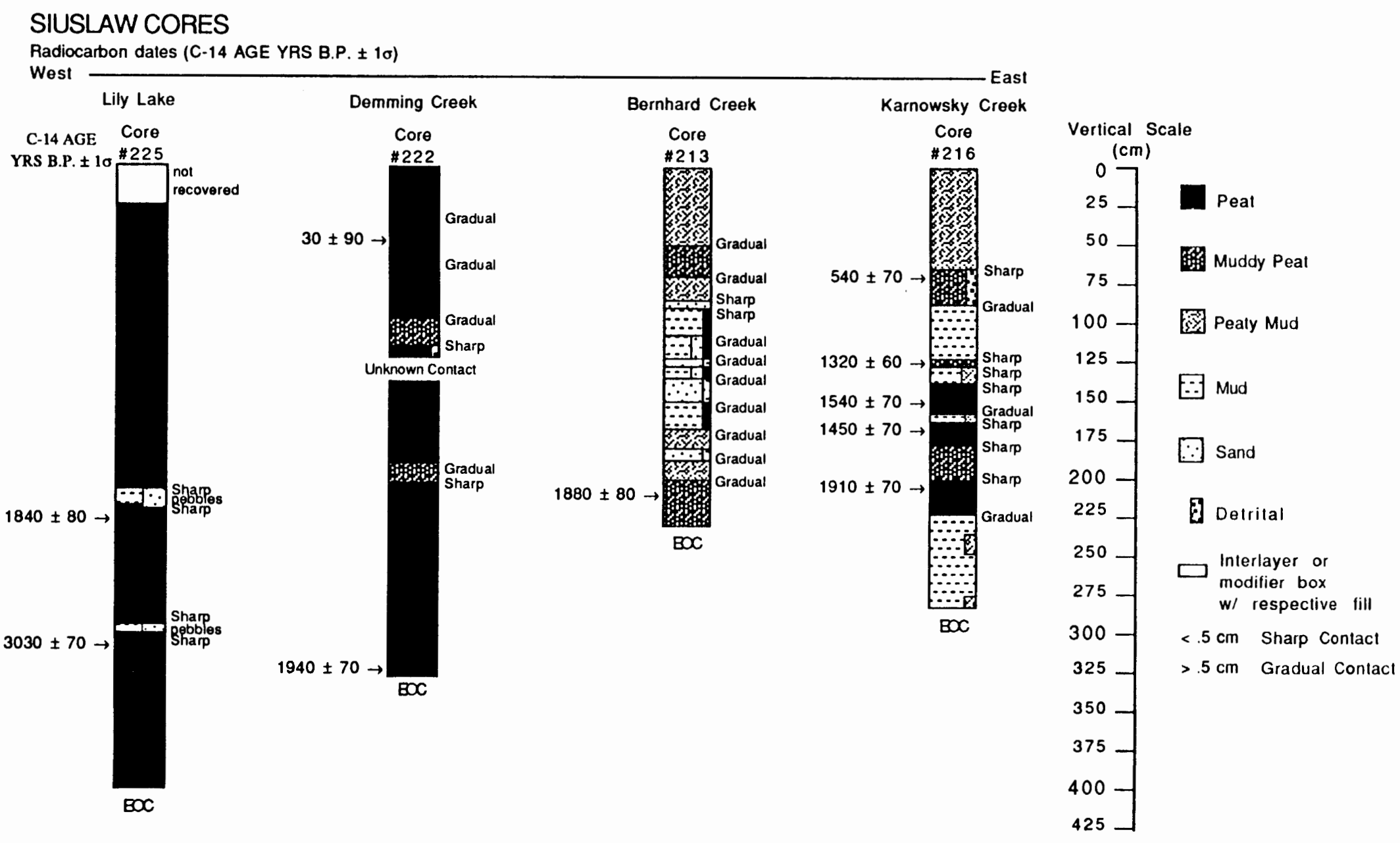

Figure 6. Siuslaw area radiocarbon dated cores. Elevation corrections for the tops of these cores were $+0.72 \mathrm{~m}$ to $+1.10 \mathrm{~m}$ above MSL (high marsh, upper intertidal level). Core 225 was not surveyed into mean sea level (MSL). 


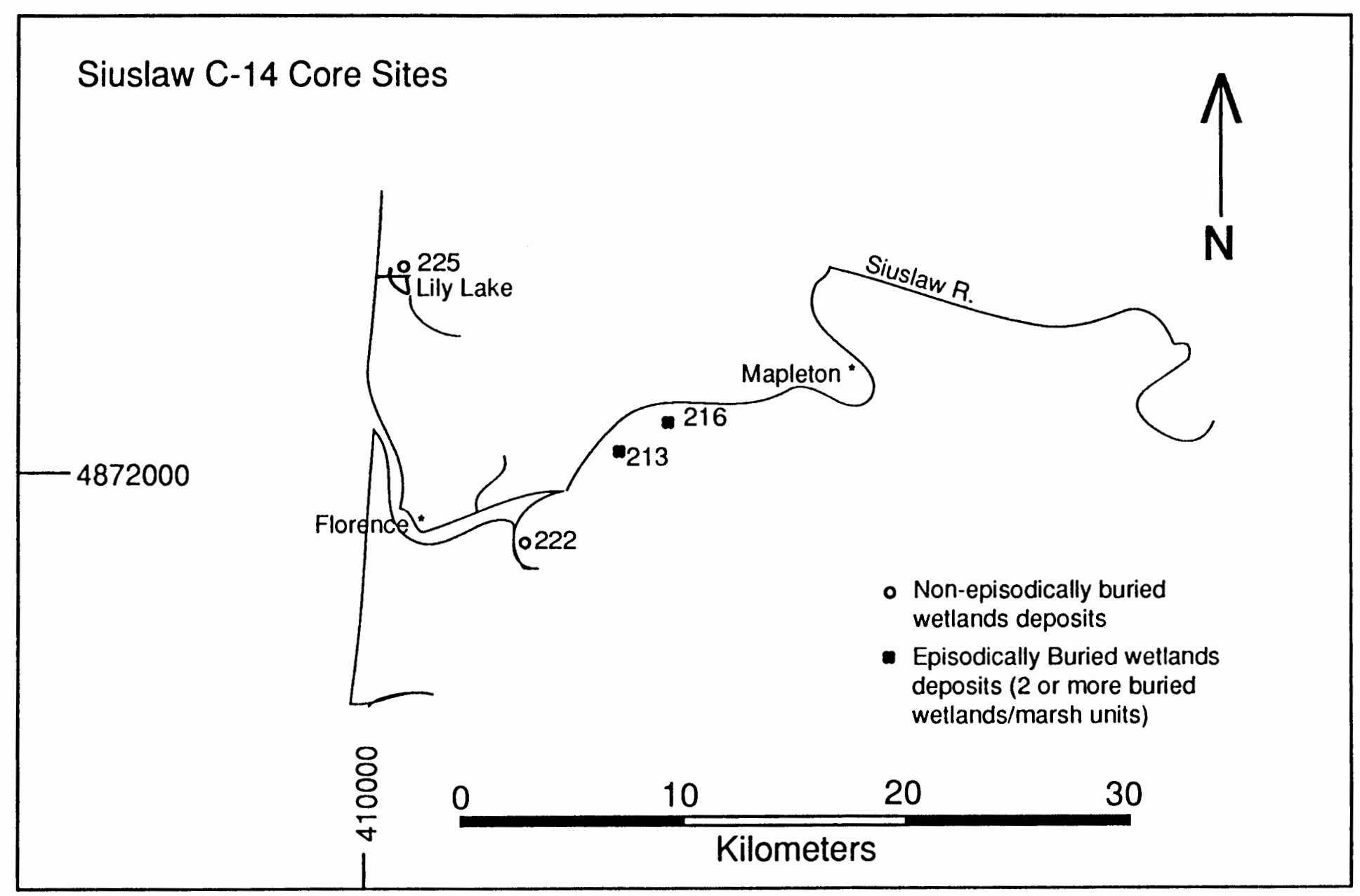

Figure 7. Siuslaw C-14 dated cores - site map. 
Stratigraphy:

Cores are discussed in order based on their location west to east. Peat composition is estimated by visual examination of split core surfaces. See TABLE I (p.21) previously shown.

Contacts between buried peats and other distinctive lithologies, e.g. sand or barren muds, are defined as sharp ( $<0.5 \mathrm{~cm}$ thickness) or gradual (> $0.5 \mathrm{~cm}$ thickness). Buried marsh units (Mu) are numbered in descending order from the top of the core to the end of the core (EOC). Mu 0 refers to the surface modern marsh/peat unit. Mu 1 refers to the first occurrence of a distinctly buried peat below the surface. Mu 2 refers to the second buried marsh/peat unit, etc.,.

\section{Lily Lake Cores - 204, 205, 224, 225}

Lily Lake is a perched fresh water pond separated from the ocean by approximately 500 meters of sand dune (figure 5). A small overflow creek runs through the dunes. However, lake level is likely controlled by a ground water connection to sea level, through the highly permeable dune aquifer. The water level of the lake has risen in recent Holocene time as indicated by continuous peat deposits in cores 225, 204, 205, and 224. Peat production around the edge of the pond was sufficient to keep up with sea level rise in the late Holocene. 
Cores 204, 205 and 224 all contained continuous peaty deposits down core to depths of at least $175 \mathrm{~cm}$. The top 100 $\mathrm{cm}$ of core 204 was lost because it was so fluid that it flowed out of the core barrel. The last $100 \mathrm{~cm}$ of core 224 graded downward into a sandy mud.

Core 225 (figure 6)-This $400 \mathrm{~cm}$ core consists of continuous peat interrupted by 2 distinct mudflow deposits. The first mudflow deposit is at a depth of $213 \mathrm{~cm}$, the second at $300 \mathrm{~cm}$. Radiocarbon dating of the peat just below each mud deposit yields a date of $1840 \pm 80$ years RCYBP for the upper deposit and $3030 \pm 70$ years RCYBP. for the lower deposit. The presence of continuous peat down core (excluding growth through the mudflow deposits) suggests that the lake bottom level has gradually risen with the gradual rise of relative sea level during the last 3,000 years. The lack of abrupt peat burial in the Lily Lake cores prohibits any test of coseismic origins for the debris flow deposits.

\section{Cox Island Cores - 206}

Cox Island is approximately $6 \mathrm{~km}(3.7 \mathrm{mi})$ inland from the ocean and is centrally located in the main channel of the Siuslaw River (figure 5). 
Core 206- This core, from Cox Island, reached $200 \mathrm{~cm}$ in subsurface depth and contained a record of mud deposition and marsh growth. The top $25 \mathrm{~cm}$ of the core shows continuous peat. From $25 \mathrm{~cm}$ to $70 \mathrm{~cm}$ the core consists of mud. The section from $70 \mathrm{~cm}$ to $100 \mathrm{~cm}$ was lost from the core during the process of removing it from the ground. From $100 \mathrm{~cm}$ to $150 \mathrm{~cm}$ there is a muddy peat which grades gradually downward into a peat which extends between $150 \mathrm{~cm}$ and $168 \mathrm{~cm}$. Mud is found at a depth of $168 \mathrm{~cm}$ to the bottom of the core at 200 cm. It is not possible to determine the nature of the contact between the buried peat and the overlying mud because this portion of the core is missing. This incomplete core is recorded here because it has the shallow mud layer which is anomalous for this area. This author has noted the presence of small, shallow ponds (depressions) in some high-marsh settings. The origin of these depressions is not known to this author.

\section{Deming Creek Cores - 207, 221, 222, 223}

Deming Creek is just off South Inlet which flows into the Siuslaw River (figure 5). It is approximately $6.5 \mathrm{~km}$ (4 mi) due east of the ocean.

Core 222 (figure 6)- This core contains $325 \mathrm{~cm}$ of continuously deposited peat. The basal peat at a depth of 
$322 \mathrm{~cm}$ has a radiocarbon date of $1940 \pm 70$ years RCYBP. The continuity of peat development at this site argues for gradual submergence for the last couple of thousand years.

core 221- The top $365 \mathrm{~cm}$ of this $500 \mathrm{~cm}$ core contains continuously deposited muddy peat broken by a narrow sand layer with a sharp upper contact at $365 \mathrm{~cm}$ and a sharp lower contact at $367 \mathrm{~cm}$. From $367 \mathrm{~cm}$ to $500 \mathrm{~cm}$ there is a continuous deposit of slightly peaty mud.

Core 223-A $400 \mathrm{~cm}$, nearly continuous, peaty sequence is broken by a thin sand layer and is overlaid by a detrital wood layer at a depth of 268-275 cm. Both this core and core 221, discussed above, contain thin sand layers. The medium fine grain size of these sand layers is characteristic of beach sand in the lower reaches of the estuary, implying the potential for a marine surge origin. Tsunami or some other catastrophic flood mechanism is needed to place these distinct sand layers at supratidal elevations.

Core 207- The top $100 \mathrm{~cm}$ of this $300 \mathrm{~cm}$ core flowed out of the core barrel. The remaining $200 \mathrm{~cm}$ is characterized by a continuously deposited peat.

\section{North Fork of the Siuslaw River cores - 208, 209}

The North Fork of the Siuslaw River is approximately 5-6 $\mathrm{km}(3-3.6 \mathrm{mi})$ inland from the ocean (figure 5). 
Core 208- This core was taken from a marshy area, undisturbed by channel changes, on the bank $=$ i the North Fork of the Siuslaw River just west of Bull Islanc. The $400 \mathrm{~cm}$ core consists of continuously deposited peat with a thin sand layer at a depth of $350 \mathrm{~cm}$.

Core 209- This core was taken at the outside edge of a migrating meander bend of the North Fork. It is $400 \mathrm{~cm}$ long. The top $25 \mathrm{~cm}$ is peat, followed by mud from $25 \mathrm{~cm}$ to $230 \mathrm{~cm}$. At this point there is a sharp contact with continuous peat to $280 \mathrm{~cm}$. Below this peat is a deposit of mud to $325 \mathrm{~cm}$. The remaining $75 \mathrm{~cm}$ of the core is peat. This depositional layering would suggest episodically buried marshes but the location from which the core was taken louter edge of a migrating meander) could have affected the depositional record. That is to say that the peat and mud deposition recorded in this core might be the result of changes in the river channel position (i.e. peat scoured out and mud deposited) rather than episodically buried wetlands from coastal submergence.

\section{Haring Creek Core - 201}

Haring Creek is an inlet, approximately $8 \mathrm{~km}(4.9 \mathrm{mi})$ due east of the ocean, on the North Fork of the Siuslaw River (Eigure 5) . 
Core 201- This core was taken from a marsh area protected from recent migrations of the river channel. This $600 \mathrm{~cm}$ core contains a record of one wetland burial. The top $40 \mathrm{~cm}$ of the core is continuous peat. Underlying the peat is a peaty mud to a depth of $65 \mathrm{~cm}$. From $65 \mathrm{~cm}$ to $100 \mathrm{~cm}$ the core consists of peaty sand. This changes to mud at $100 \mathrm{~cm}$. At $150 \mathrm{~cm}$ there is a sharp contact with peat. The peat continues down core for another $450 \mathrm{~cm}$ from this contact to the end of the core at a depth of $600 \mathrm{~cm}$.

The remaining cores were all taken eastward of Haring and Deming Creeks of the Siuslaw River System, and all differ from the previous cores in that they do not show evidence of continuous uninterrupted peat development.

\section{Bernhardt Creek Cores - 202, 210, 211, 212, 213}

Bernhardt Creek is an inlet on the south side of the Siuslaw River and is approximately $10 \mathrm{~km}(6.1 \mathrm{mi})$ due east of the ocean (Eigure 5).

core 213 (figure 6)-This is a pound core which contains evidence of at least two abruptly buried wetland marshes. Muddy peat/peaty mud is evident in the top $85 \mathrm{~cm}$. At $87 \mathrm{~cm}$ there is a sharp contact with a narrow sand layer $1-2 \mathrm{~cm}$ thick. From $87 \mathrm{~cm}$ to $120 \mathrm{~cm}$ there is a deposit of slightly 
rooted mud. A slightly muddy peaty sand extends downcore from $120 \mathrm{~cm}$ and grades into a slightly rooted mud to a depth of $165 \mathrm{~cm}$. From $165 \mathrm{~cm}$ to $185 \mathrm{~cm}$ the core contains peaty mud. A slightly muddy sand is evident from $185 \mathrm{~cm}$ to $188 \mathrm{~cm}$ downcore. From $188 \mathrm{~cm}$ to 200 there is a peaty mud with a gradual contact at a depth of $200 \mathrm{~cm}$ and from $200 \mathrm{~cm}$ to the bottom of the core at $235 \mathrm{~cm}$ there is muddy peat The basal radiocarbon date of the bottom muddy peat was $1180 \pm 80$ RCYBP at a depth of $210 \mathrm{~cm}$. This core shows two or three buried peats separated by two (possibly three) distinct sand layers. These anomalous sandy horizons are found at depths of $87 \mathrm{~cm}$, $135 \mathrm{~cm}$ (uncertain), and $185 \mathrm{~cm}$. The contact between the muddy peat and the peaty mud (overlying) is gradual. Also noted, at a depth of $110 \mathrm{~cm}$, is an injection (liquefaction) feature. This sill flame-like injection feature is approximately $2.5 \mathrm{~cm}$ in height.

Core 202- This core was taken upstream from core 213, at Bernhardt Creek, in an area less subject to the effects of the Siuslaw River channel migrations. It contains three buried marsh units. The core is $385 \mathrm{~cm}$ long. The first 60 $\mathrm{cm}$ are peat, from $60 \mathrm{~cm}$ to $70 \mathrm{~cm}$ the core is mud which tops a muddy peat to $100 \mathrm{~cm}$. From 100 to $200 \mathrm{~cm}$ slightly sandy, very slightly rooted mud is present. Below this to $235 \mathrm{~cm}$ there is distinct muddy peat, then muddy sand to $300 \mathrm{~cm}$. From $300 \mathrm{~cm}$ to $350 \mathrm{~cm}$ a more distinct muddy peat occurs. The bottom of the core from $350 \mathrm{~cm}$ to $385 \mathrm{~cm}$ is sand and muddy 
sand. The upper contacts of the three peats are sharp contacts.

Cores 210, 211, and 212- These cores were all taken within $100 \mathrm{~m}$ of core 202 and are all $400 \mathrm{~cm}$ long. Core 212 records at least two separate burial events, core 210 had evidence of 3 separate burial events, and core 211 records one burial event. Core 211 was taken from the farthest upstream location cored in the Bernhardt Creek valley.

\section{Karnowsky Creek Cores - 214, 215, 216}

These cores were taken from marshy areas near Karnowsky Creek, a small tributary stream approximately $12 \mathrm{~km}(7.3 \mathrm{mi})$ due east of the ocean, on the south side of the siuslaw river (figure 5).

Core 216 (figure 6)- This core contains evidence of episodic marsh subsidence. The $285 \mathrm{~cm}$ core contains peaty mud from the surface to a depth of $65 \mathrm{~cm}$. From $65 \mathrm{~cm}$ to 90 cm there is a muddy peat with a sharp upper contact. The upper portion of this peat is radiocarbon dated at $540 \pm 70$ years RCYBP. From $90 \mathrm{~cm}$ to a depth of $125 \mathrm{~cm}$ there is mud. At $125 \mathrm{~cm}$ to $128 \mathrm{~cm}$ there is a distinct muddy peat with a sharp upper contact. This peat has a radiocarbon date of dated $1320 \pm 60$ years RCYBP. From $128 \mathrm{~cm}$ to $135 \mathrm{~cm}$ there is mud. At $135 \mathrm{~cm}$ to $160 \mathrm{~cm}$ there is a layer of peat. This 
peat is dated at $1540 \pm 70$ years RCYBP. Sandy mud wich some rootlets is found from $160 \mathrm{~cm}$ to $162 \mathrm{~cm}$. These rootlets extend from the peat above, through this sandy mud and into the peat below. At $162 \mathrm{~cm}$ there is a peat with a sharp upper contact. This peat continues to a depth of $175 \mathrm{~cm}$. This peat radiocarbon dated at $1450 \pm 70$ years RCYBP. These last two events are within one standard deviation of each other and may reflect rootlet cross contamination. This may explain the reversal of these two dates of these two events seen in this core. At $175 \mathrm{~cm}$ to $200 \mathrm{~cm}$ there was muddy peat and from 200 to $225 \mathrm{~cm}$ there is a peat which dated at $1910 \pm$ 70 RCYBP. The remainder of the core from $225 \mathrm{~cm}$ to $285 \mathrm{~cm}$ is mud. This core records five distinct burial events. Core 214- Taken $80 \mathrm{~m}$ further upstream from core 216, this $500 \mathrm{~cm}$ long core shows evidence of 3 distinct wetland burial episodes, Mu 1 at 70-180 cm, Mu 2 at 200-325 cm and Mu (buried Marsh unit) 3 at 300-375 cm. From the top down this core contains surface peaty mud to $20 \mathrm{~cm}$, then slightly peaty mud from $20 \mathrm{~cm}$ to $70 \mathrm{~cm}$. Muddy peat grading into peat was found at $70 \mathrm{~cm}$ to $180 \mathrm{~cm}$. From $180 \mathrm{~cm}$ to $200 \mathrm{~cm}$ there is a slightly rooted mud and from $200 \mathrm{~cm}$ to $325 \mathrm{~cm}$ there is peat gradually grading into peaty mud. Slightly rooted mud is found at $325 \mathrm{~cm}$ to $360 \mathrm{~cm}$. Peaty mud appears at $360 \mathrm{~cm}$ to $375 \mathrm{~cm}$. Below this, to the bottom of the core at $400 \mathrm{~cm}$ is slightly rooted mud. 
Lore 215- This core recorjs 3 marsh burial events, Mu 1 at $120-140 \mathrm{~cm}, \mathrm{Mu} 2$ at $170-265 \mathrm{~cm}$, and $\mathrm{Mu} 3$ at 315 to 345 $\mathrm{cm}$. Erom the surface to $120 \mathrm{~cm}$ this core contained slightly rooted mud. From $120 \mathrm{~cm}$ to $140 \mathrm{~cm}$ there was peaty mud and this topped slightly rooted mud at $140 \mathrm{~cm}$ to $170 \mathrm{~cm}$. A muddy peat grading to a peaty mud was found from $170 \mathrm{~cm}$ to $265 \mathrm{~cm}$. At $265 \mathrm{~cm}$ to $315 \mathrm{~cm}$ there is slightly rooted mud and below this, from $315 \mathrm{~cm}$ to $345 \mathrm{~cm}$ is muddy peat. Slightly rooted mud is at the bottom of the core from 345 to $500 \mathrm{~cm}$.

\section{Huffman Creek Cores - 203}

Huffman Creek, approximately $16 \mathrm{~km}(9.75 \mathrm{mi})$ due east of the ocean, is an inlet on the south side of the Siuslaw River (figure 5).

Core 203- There is evidence of 2 buried marshes in the $250 \mathrm{~cm}$ long core. The top $25 \mathrm{~cm}$ contains peat. Between 25 $\mathrm{cm}$ and $75 \mathrm{~cm}$ there is a $50 \mathrm{~cm}$ layer of sand of uncertain origin (probably deposited river sand resulting from channel migration) which tops slightly peaty mud at $75 \mathrm{~cm}$ to $90 \mathrm{~cm}$. From $90 \mathrm{~cm}$ to $100 \mathrm{~cm}$ there is mud which contains a very small amount of sand. Very peaty mud was found at $100 \mathrm{~cm}$ to $140 \mathrm{~cm}$ and from $140 \mathrm{~cm}$ to $250 \mathrm{~cm}$ there was mud with a few rootlets just below the peaty mud at $140 \mathrm{~cm}$. 


\section{Sweet Creek cores - 217}

This small meandering creek flows through a relatively wide valley. It is an inlet on the south side of the Siuslaw River, and it is approximately $19 \mathrm{~km}(11.6 \mathrm{mi})$ due east of the ocean (figure 5).

Core 217- This core is $300 \mathrm{~cm}$ long. Muddy peat is evident from the top surface of the core to a depth of $50 \mathrm{~cm}$. Very slightly rooted mud is found at $50 \mathrm{~cm}$ to $90 \mathrm{~cm}$ and it overlays a peaty mud at $90 \mathrm{~cm}$ to $110 \mathrm{~cm}$. From $110 \mathrm{~cm}$ to 170 $\mathrm{cm}$ mud with some sand and a few rootlets is evident. A peat is found at $170 \mathrm{~cm}$ to $190 \mathrm{~cm}$. Below the peat a mud layer is evident from $190 \mathrm{~cm}$ to $300 \mathrm{~cm}$ (end of core). This core records two buried events, one at $90 \mathrm{~cm}$ and the other at 170 $\mathrm{cm}$.

Hadsall Creek Cores - 218, 219, 220

This is an inlet on the south side of the Siuslaw River approximately $24 \mathrm{~km}(14.6 \mathrm{mi}$ ) due east of the ocean (figure $5)$.

Core 218- of the cores taken near Hadsall Creek, this core was taken at a location closest to the Siuslaw River. It records 4 burial events, Mu 1 at $170 \mathrm{~cm}$, Mu 2 at $268 \mathrm{~cm}$, 
Mu 3 at $280 \mathrm{~cm}$, and Mu 4 at $290 \mathrm{~cm}$. The marsh units at 268 $\mathrm{cm}$ and $280 \mathrm{~cm}$ are each $5 \mathrm{~cm}$ thick with a slightly rooted mud layer in between them. They may represent one marsh unit rather than two.

Core 219- This core was taken from a location adjacent to and upstream of core 218. It is $400 \mathrm{~cm}$ long. The portion of the core from the top to a depth of $65 \mathrm{~cm}$ is muddy peat. From 65 to $75 \mathrm{~cm}$ it is mud which tops muddy peat (sharp contact) at $75 \mathrm{~cm}$ to $100 \mathrm{~cm}$. Slightly rooted mud is found at $100 \mathrm{~cm}$ to $125 \mathrm{~cm}$ and a muddy peat grading downward into a peat, containing four mud laminates, which extends from 125 $\mathrm{cm}$ to $315 \mathrm{~cm}$. Mud is found at $315 \mathrm{~cm}$ to $375 \mathrm{~cm}$ and it tops a layer of sand at $375 \mathrm{~cm}$ to $400 \mathrm{~cm}$.

Core 220- The top $13 \mathrm{~cm}$ of this core flowed out of the core barrel. From $13 \mathrm{~cm}$ to $50 \mathrm{~cm}$ there is muddy peat and at $50 \mathrm{~cm}$ to $190 \mathrm{~cm}$ there are mud and peat laminates (multiple thin peat layers topped with mud). Peat is found below this at $190 \mathrm{~cm}$ to $240 \mathrm{~cm}$. The bottom of the core from $240 \mathrm{~cm}$ to $250 \mathrm{~cm}$ consists of slightly rooted mud.

It is noted that progressing west to east in the siuslaw River Basin the cores change in nature from continuous peats to episodically buried peats and the incidence of sharp contacts increases. This suggests sudden, rather than gradual subsidence. 
TABLE IV

SUMMARY OF SIUSLAW C-14 DATES

$\begin{array}{lll}\text { CORE\# } & \text { DEPTH } & \text { AGE } \\ 225 & 218 \mathrm{~cm} & 1840 \pm 80 \mathrm{yrs} \\ & 310 \mathrm{~cm} & 3030 \pm 70 \mathrm{yrs} \\ 222 & 322 \mathrm{~cm} & 1910 \pm 70 \mathrm{yrs} \\ 213 & 210 \mathrm{~cm} & 1880 \pm 80 \mathrm{yrs} \\ 216 & 68 \mathrm{~cm} & 540 \pm 70 \mathrm{yrs} \\ & 127 \mathrm{~cm} & 1320 \pm 60 \mathrm{yrs} \\ & 153 \mathrm{~cm} & 1540 \pm 70 \mathrm{yrs} \\ & 167 \mathrm{~cm} & 1450 \pm 70 \mathrm{yrs} \\ & 210 \mathrm{~cm} & 1910 \pm 70 \mathrm{yrs}\end{array}$

\section{DIATOMS}

There is a limit to the value that analysis of diatom assemblages can provide in explaining depositional environments. Seasonal and other environmental variables which can impact accurate interpretation of diatom data will be addressed in the discussion and conclusion section. It can be said at this point that studies have shown that fresh water diatoms dominate in areas where water salinity is $5 \%$ or less. Below this level of salinity the incidence of marine/brackish diatoms drops off dramatically. Therefore, 
it is reasonable to expect that the incidence of marine/brackish diatoms would decrease at some point inland from the ocean beyond the reach of saltwater intrusions and in marsh areas which have been uplifted beyond the reach of high tides. Note that almost all samples (the few exceptions will be noted) evaluated for the presence of marine/brackish water diatoms contain a high $(150+)$ count of whole frustule freshwater diatoms.

Three cores taken from the Siuslaw Bay study area were analyzed for the presence of whole frustule marine/brackish water marker diatoms (TABLE V). These are core 222 at Deming Creek, core 216 at the mouth of Karnowsky Creek, and core 225 at Lily Lake.

Core 225 Lily Lake- This is a fresh water perched pond within $0.5 \mathrm{~km}(0.31 \mathrm{mi})$ due east of the ocean. This 200 $\mathrm{cm}$ long core consists of continuous peat. The oldest radiocarbon date from the core is 3,000 RCYBP at a depth of $325 \mathrm{~cm}$. Samples for diatom analysis taken from this core at varying depths show a complete lack of marine/brackish water marker diatoms, suggesting that the lake has been cut off from the ocean for at least 3,000 years. The Lily Lake samples also contain very low counts ( $<30$ per slide) of freshwater diatoms.

Core 216 Karnowsky Creek- This $285 \mathrm{~cm}$ core contains evidence of five marsh burial events. Samples for diatom 
TABLE V

\section{SIUSLAW MARINE/BRACKISH DIATOM SAMPLING COUNTS}

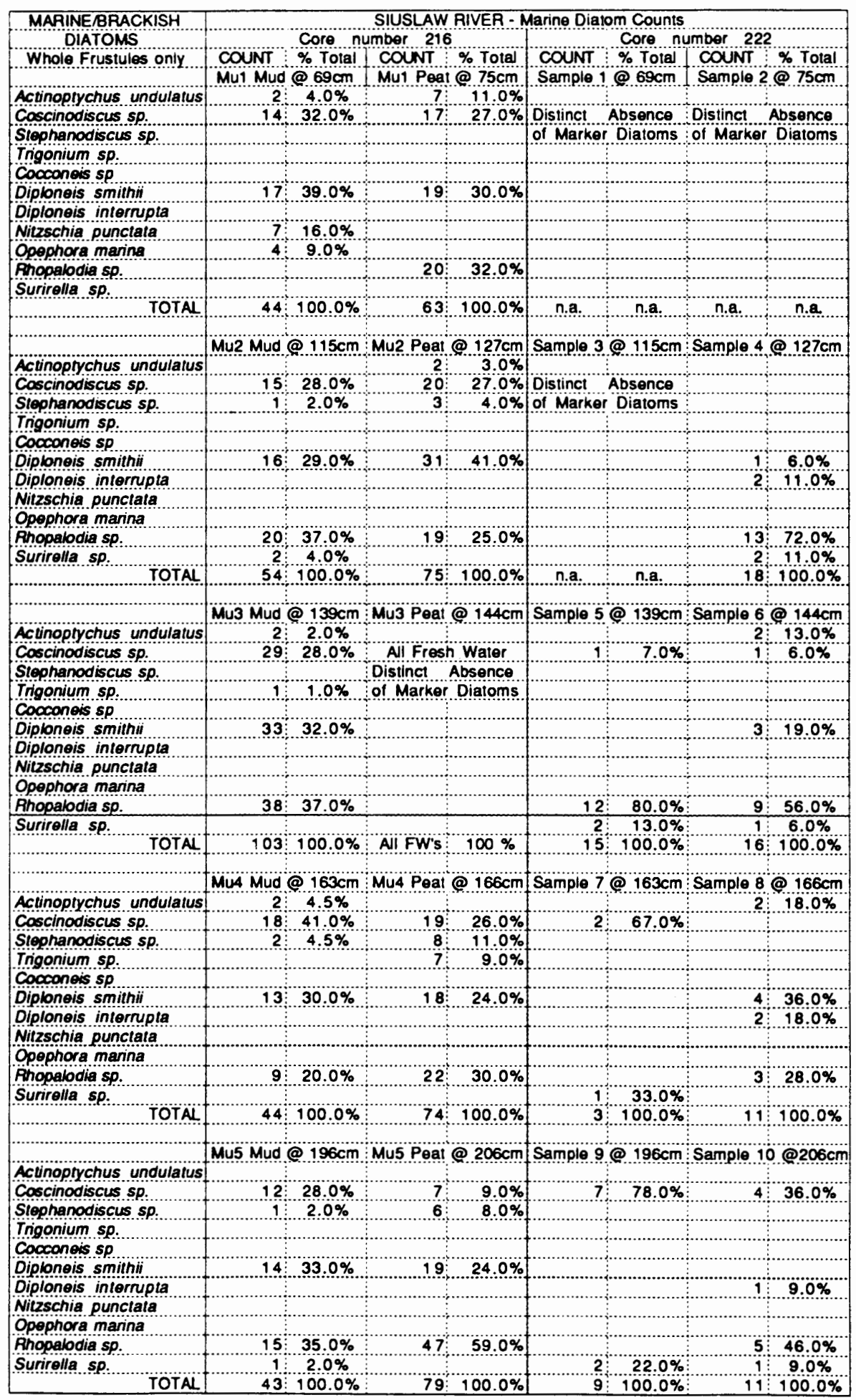


analysis were taken down core from mud at $69 \mathrm{~cm}$, peat at 75 $\mathrm{cm}$, mud at $115 \mathrm{~cm}$, peat at $127 \mathrm{~cm}$, mud at $139 \mathrm{~cm}$, peat at 144 $\mathrm{cm}$ (this sample is dated at $1540 \pm 70$ RCYBP), mud at $163 \mathrm{~cm}$, peat at $166 \mathrm{~cm}$, mud at $196 \mathrm{~cm}$, and peat at $206 \mathrm{~cm}$ (this sample is dated at $1919 \pm 70$ RCYBP) (Table V). There appears to be no distinct variations of marine/brackish water diatoms among the diatom assemblages seen in each sample with the exception of the sample taken at a depth of $144 \mathrm{~cm}$. This sample shows the presence of solely fresh water diatoms, suggesting that this area was cut off from the ocean, probably uplifted to supratidal elevations for an indeterminable reason around $1540 \pm$ RCYBP. The other samples from this core contain assemblage counts of 43 to 103 marker diatoms. This variation could be attributed to environmental factors other than changes in tidal elevation (see discussion section). Each of the five mud/peat burial events contain slight differences in the diatom assemblage count seen in the mud layer when compared with its corresponding peat layer. Slightly higher counts are found in the peat samples.

Core 222 Deming Creek- This core consists of continuous peat and is $325 \mathrm{~cm}$ long. Its oldest date is 1940 \pm 70 RCYBP. The core was sampled for diatom analysis at the same depths as core 216 (Table V). In the first $115 \mathrm{~cm}$ three samples were taken which show the complete absence of all marine/brackish water marker diatoms. Seven samples were taken between $115 \mathrm{~cm}$ and $206 \mathrm{~cm}$. The samples contain small 
numbers of marine/brackish water marker aiatoms. These smail counts suggest an environment of ocean water of varying low salinity anc accompanying plant species variation. The complete lack of distinct marine/brackish marker diatoms above the depth of $115 \mathrm{~cm}$ may be because the area was out off from the ocean. According to local residents, this area has been cut off from tidal influence by a tidal gate for the past forty years (the sample taken at a depth of $50 \mathrm{~cm}$ is dated at $30 \pm 90$ RCYBP). This (or the tidal gate) may account for a lack of marine/brackish water marker diatoms in the upper $115 \mathrm{~cm}$ of the core.

\section{LOWER UMPQUA RIVER AREA}

Core Locations:

The lower Umpqua River area is located on the southcentral oregon coast at approximately UTM4840000 $\mathrm{mN}$ (figure 8). Thirty-eight cores were taken in this area, numbered 301 through 339. The number 324 was not assigned to a core site (i.e. never taken). Ten cores $(301,311,321,328,327,330$, $332,334,337$, and 339) were vibra/pound cores. Seven of these ten cores were sampled for radiocarbon dating (figure 9). These were, from west to east, core 339 from winchester Bay, core 328 from Providence Creek, core 301 from scholfield Creek, core 311 from Butler Creek, core 321 from Oar Creek, 


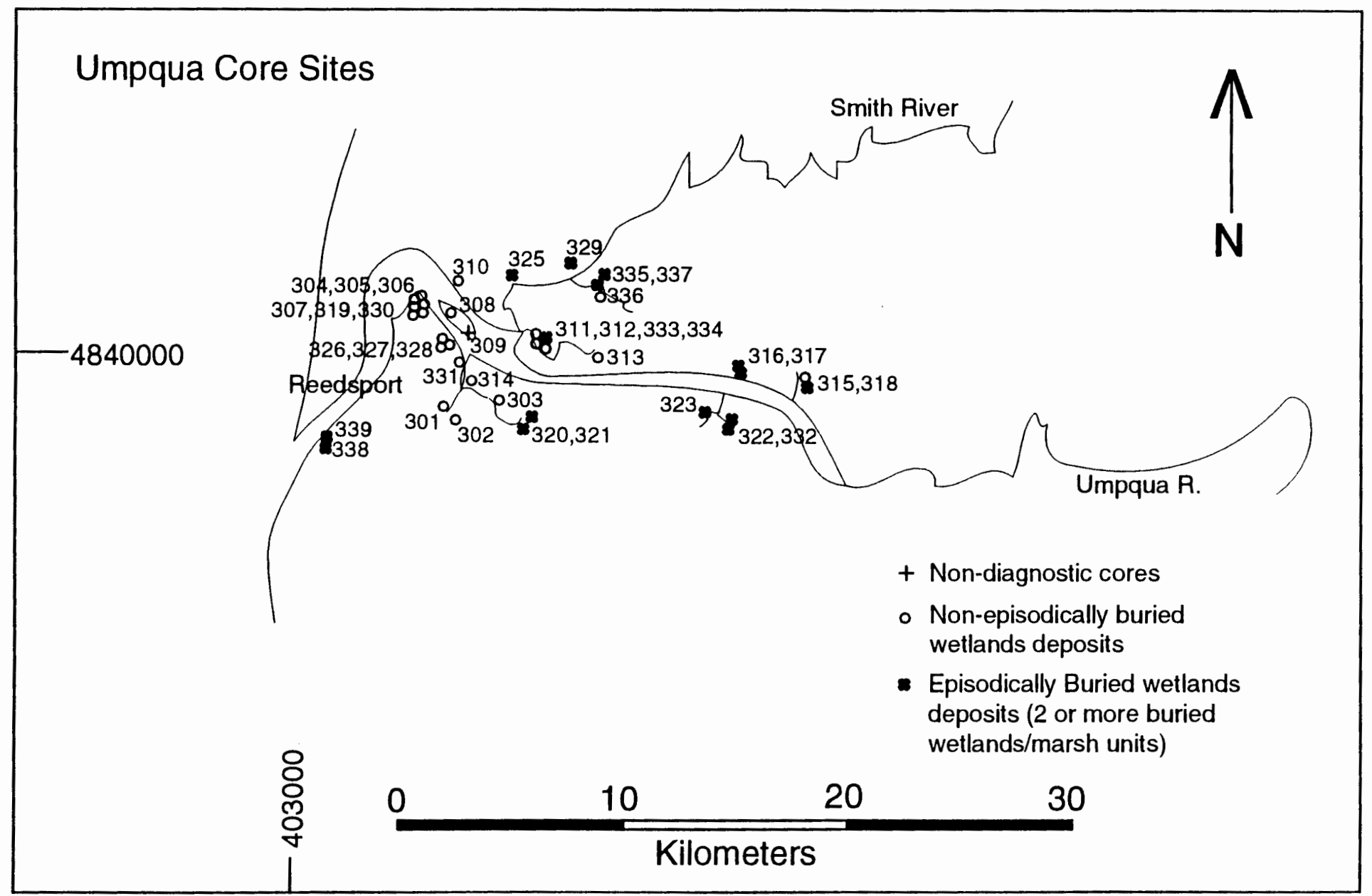

Figure 8. Umpqua River core location map. Sites included tidal marshes and tidally influenced tributary streams of the Umpqua and Smith Rivers. 


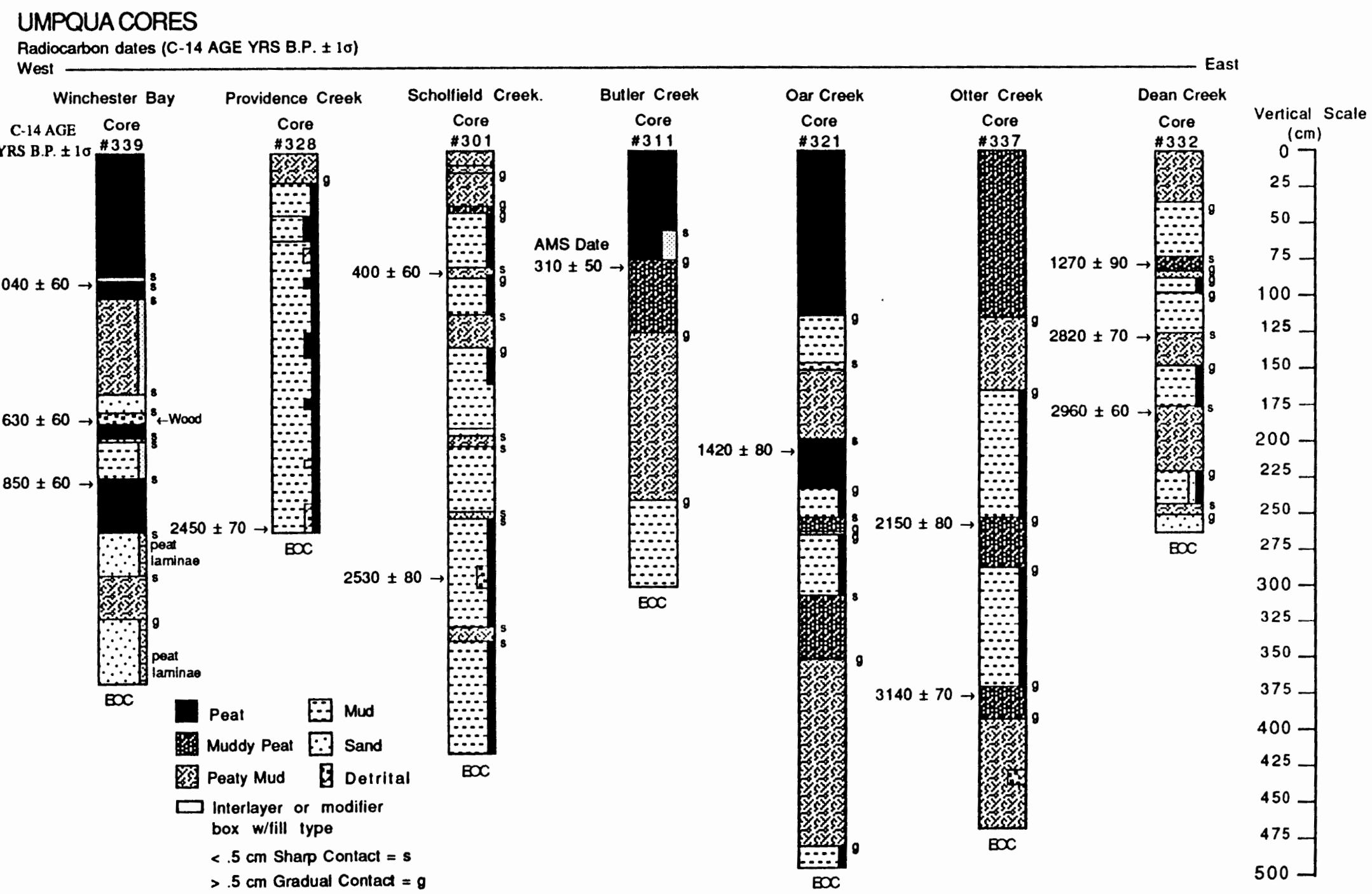

Figure 9. Umpqua area radiocarbon dated cores. Area coring site elevation corrections for the tops of cores were between $+0.59 \mathrm{~m}$ and $2.46 \mathrm{~m}$ above MSL (see appendix B). 
core 337 from Otter Creek, and core 332 from Dean Creek (figure 10 - Umpqua C-14 core site map).

Cores were taken from tidal marshes on Umpqua Bay, Umpqua River, Smith River branch and tidally influenced tributary streams of the Umpqua and Smith Rivers. Cores were taken in the Umpqua Bay area up to $21 \mathrm{~km}(12.8 \mathrm{mi}$.$) due east$ of the ocean as far as Harvey Creek.

As with the Siuslaw Bay cores, elevations for core sites were corrected to mean sea level and are recorded in Appendix $B$ for future use in correlation. Field core logs which document regional marsh stratigraphic records are shown in Appendix A.

Stratigraphy:

Cores are discussed in order based on the location from which they were taken from west to east. Peat composition was estimated by visual examination of split core surfaces using the criteria from TABLE I.

Contacts between buried peats and other distinctive lithologies, e.g. sand or barren muds are defined as noted in METHODS.

Winchestex Bay Cores- $338, \quad 339$

These cores were taken on Silver Creek. Silver Creek flows into the Umpqua River at the east end of Winchester Bay 


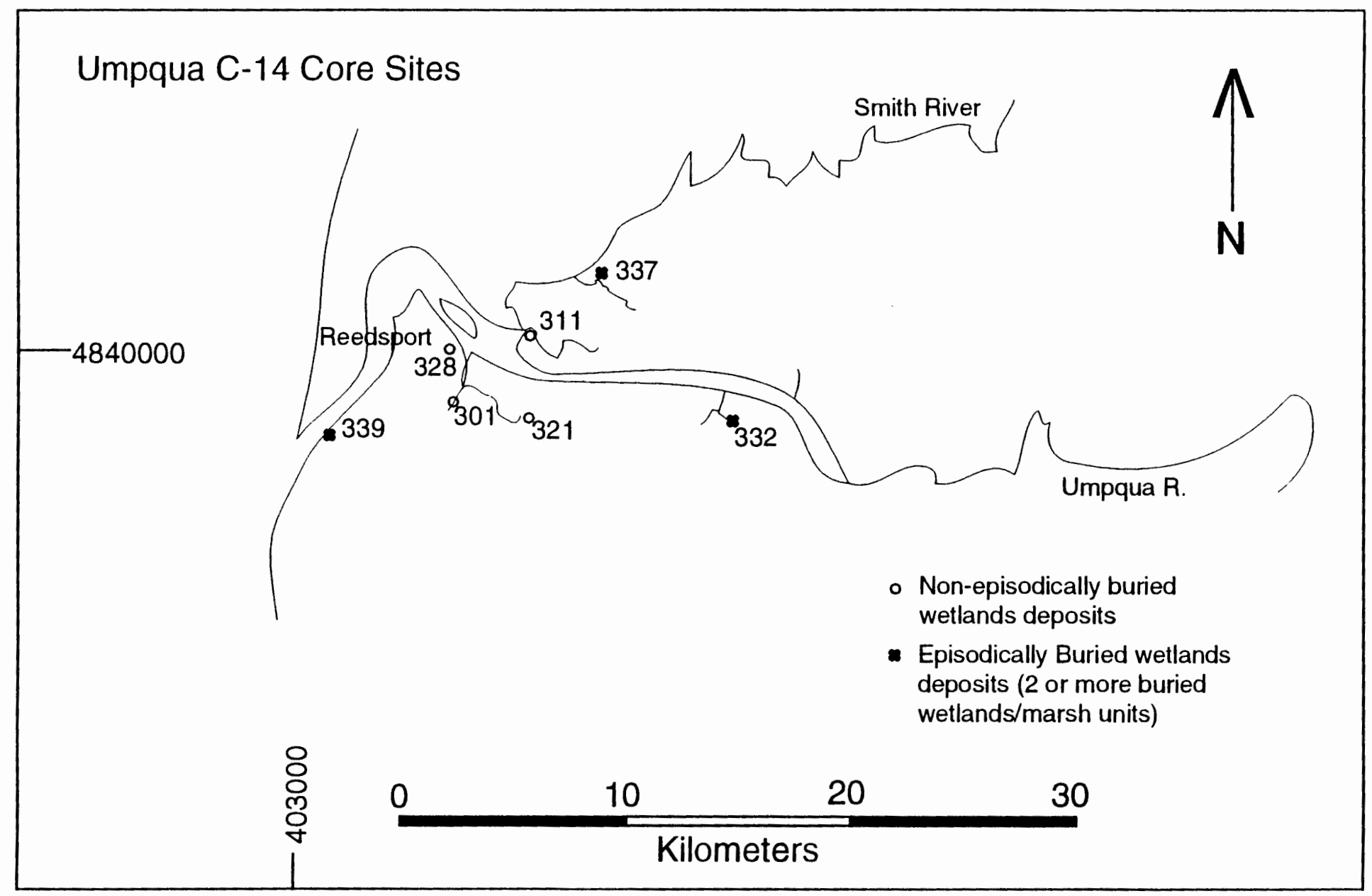

Figure 10. Umpqua River C-14 dated cores - site map. 
approximately $3 \mathrm{~km}(1.8 \mathrm{mi}$ ) due east of the ocean (figure 8).

Core 339 (Eigure 9)- This $370 \mathrm{~cm}$ long core shows evidence of four buried peats. The top $85 \mathrm{~cm}$ consists of continuous peat. From $85 \mathrm{~cm}$ to $87 \mathrm{~cm}$ there is a distinct sand layer with sharp upper and lower contacts. Peat extends downward from $87 \mathrm{~cm}$ to $100 \mathrm{~cm}$ with a sharp lower contact at $100 \mathrm{~cm}$. A sample taken from this peat at $89 \mathrm{~cm}$ is radiocarbon dated at $1040 \pm 60 \mathrm{RCYBP}$. From $100 \mathrm{~cm}$ to $170 \mathrm{~cm}$ is a slightly sandy peaty mud. A thick sand layer with sharp upper and lower contacts is evident down core from $170 \mathrm{~cm}$ to $177 \mathrm{~cm}$. A detrital layer extends from $177 \mathrm{~cm}$ to $180 \mathrm{~cm}$ where it grades into peat. Wood from this detrital layer is dated at $1630 \pm 60 \mathrm{RCYBP}$. The peat layer extends to $190 \mathrm{~cm}$. It has a sharp lower contact. At $190 \mathrm{~cm}$ there is a distinct 1 cm layer of fine sand with a sharp lower contact. From 191 $\mathrm{cm}$ to $223 \mathrm{~cm}$ there is a slightly sandy mud. A peat layer with sharp upper and lower contacts extends down core from $223 \mathrm{~cm}$ to $260 \mathrm{~cm}$. The upper portion of this peat layer is dated at $1850 \pm 60$ RCYBP. Sand containing peaty mud laminaes is found from $260 \mathrm{~cm}$ down to $290 \mathrm{~cm}$. From $290 \mathrm{~cm}$ to $320 \mathrm{~cm}$ is a peaty mud which has a sharp upper contact and a gradual lower contact. At $320 \mathrm{~cm}$ the peaty mud grades into a sand containing peaty mud laminaes to the end of the core at 370 cm. The sharp lower contacts associated with the peat layers is suggestive of uplift. These sharp lower contacts are also 
seen in core 338. Both cores were taken west of the area where continuous peat cores are seen. The location of the cores and the sharp contacts observed are consistent with the evidence of uplift expected on the oceanward side of the zero-isobase. Two cores out of all the cores taken across the Umpqua area are not sufficient to define the oceanward extent of the zero-isobase.

Core 338- This gouge core was taken at the same location as core 339 and is $365 \mathrm{~cm}$ long. From the surface to $118 \mathrm{~cm}$ the core contains continuous peat. The peat contains some detrital material between $113 \mathrm{~cm}$ and $118 \mathrm{~cm}$. A slightly peaty mud with gradual upper and lower contacts is found from $118 \mathrm{~cm}$ to $152 \mathrm{~cm}$. At $152 \mathrm{~cm}$ a peaty mud extends down core to $177 \mathrm{~cm}$. It has a gradual lower contact. Below the peaty mud there is a $5 \mathrm{~cm}$ layer of fine sand with a sharp lower contact, suggestive of abrupt uplift. From $182 \mathrm{~cm}$ to $200 \mathrm{~cm}$ there is a peat layer which grades into a muddy peat. The muddy peat, which has a sharp lower contact, extends from 200 $\mathrm{cm}$ to $237 \mathrm{~cm}$. From $237 \mathrm{~cm}$ to 280 there is peat which continues downward to $280 \mathrm{~cm}$. Between $280 \mathrm{~cm}$ and $318 \mathrm{~cm}$ there is a sand layer with a gradual upper contact and a sharp lower contact. A slightly peaty mud extends from 318 $\mathrm{cm}$ to $340 \mathrm{~cm}$. The peaty mud tops a $6 \mathrm{~cm}$ thick sand layer which has a sharp upper contact and a gradual lower contact. From $346 \mathrm{~cm}$ to $355 \mathrm{~cm}$ there is a slightly sandy peaty mud. Sand is found from $355 \mathrm{~cm}$ to the bottom of the core at 365 
$\mathrm{cm}$. This sand likely represents the basal sand flat or channel bottom upon which the muds and peats were deposited.

The cut off cores $-304,305,306,307,319,330$

The Cut off marsh area is located on the big bend near the mouth of the Umpqua River approximately $4.5 \mathrm{~km}(2.7 \mathrm{mi})$ due east of the ocean (figure 8). The cores were taken from tidal marsh areas at the inside edge of the bend.

Cores 304, 305, 306, and 307-These cores are short cores $200 \mathrm{~cm}$ to $300 \mathrm{~cm}$ in length. All contain continuous muddy peat from the surface to approximately $75 \mathrm{~cm}$. From 75 $\mathrm{cm}$ to the end of each core there is sand with various small amounts of mud and detrital material. Cores 304 and 306 each have a 10-25 cm thick layer of peaty mud (containing sharp upper contacts) at a depth of approximately $110 \mathrm{~cm}$. Topping the peaty mud layer seen in cores 304 and 306 is a $15-30 \mathrm{~cm}$ thick layer of slightly muddy sand. These sands are candidate tsunami layers. Alternatively, they may represent a return to the river sand deposit layer (seen down core) after the subsidence of the peaty mud layer. These cores mark the start of the area where continuous peat cores begin to appear.

Core 319- The top $35 \mathrm{~cm}$ of this core was not recovered. This $100 \mathrm{~cm}$ core contains slightly peaty mud from $35 \mathrm{~cm}$ to 70 
cm. From $70 \mathrm{~cm}$ to $73 \mathrm{~cm}$ there is a layer of detrital material. The detrital material tops mixed mud and sand which extends to the depth of $100 \mathrm{~cm}$.

Core 330- The top $60 \mathrm{~cm}$ of this $177 \mathrm{~cm}$ core was not recovered. From $60 \mathrm{~cm}$ to $73 \mathrm{~cm}$ there is river deposited detrital material. The detrital layer tops a slightly sandy mud which extends to $85 \mathrm{~cm}$. Slightly peaty mud is seen from $85 \mathrm{~cm}$ to $117 \mathrm{~cm}$. From $117 \mathrm{~cm}$ to $124 \mathrm{~cm}$ there is a layer of sandy mud. A sand layer extends from $124 \mathrm{~cm}$ to the end of the core at $177 \mathrm{~cm}$.

\section{Steamboat Island Cores - 308, 309}

Steamboat Island is located in the middle of the Umpqua River east of the cut off (figure 8).

cores 309- This core contain peaty mud to peaty sand from the surface to approximately $40 \mathrm{~cm}$. It consists of muddy sand from $40 \mathrm{~cm}$ to the bottom of each core.

Core 308- This core is $100 \mathrm{~cm}$ long and contains peaty mud from the top to a depth of $40 \mathrm{~cm}$. From $40 \mathrm{~cm}$ to $55 \mathrm{~cm}$ there is slightly peaty mud with gradual upper and lower contacts. At $55 \mathrm{~cm}$ the slightly peaty mud grades into sand which extends to $60 \mathrm{~cm}$. At $65 \mathrm{~cm}$ slightly peaty mud with a sharp upper contact and a gradual lower contact is present and continues down to $73 \mathrm{~cm}$. From $73 \mathrm{~cm}$ to the end of the 
core at $100 \mathrm{~cm}$ slightly muddy sand is evident. The sand seen from $55 \mathrm{~cm}$ to $60 \mathrm{~cm}$ is a tsunami candidate.

Gardiner Paper Mill core -310

This core was taken from a marshy bank area on the east bank of the Umpqua River south of Steamboat Island (figure 8).

Core 310 - The top $165 \mathrm{~cm}$ of this $300 \mathrm{~cm}$ long core is continuous peaty mud with a small sand lens (strongly suggestive of a tsunami layer) at a depth of $75 \mathrm{~cm}$. From 165 $\mathrm{cm}$ to $300 \mathrm{~cm}$ there is a slightly muddy sand.

\section{East Bank Providence Creek Cores - 326, 327, 328}

These cores were taken from a tidal marsh near the mouth of Providence Creek just south of Leeds Island (figure 8).

Core 326- This $500 \mathrm{~cm}$ long core contains peaty mud. There is a gradual contact at $100 \mathrm{~cm}$ where the peaty mud grades into a slightly peaty mud. The slightly peaty mud extends down core to a depth of $430 \mathrm{~cm}$. At $430 \mathrm{~cm}$ to the end of the core at $500 \mathrm{~cm}$ there is mud. 
Core 327-This $190 \mathrm{~cm}$ continuous core consists of peaty mud beginning at the surface which grades into a slightly peaty mud at approximately $75 \mathrm{~cm}$.

Core 328-(figure 9) The top $25 \mathrm{~cm}$ of this $265 \mathrm{~cm}$ long core contains peaty mud. At $25 \mathrm{~cm}$ the peaty mud grades into a slightly peaty mud which continues to the bottom of the core. The bottom $20 \mathrm{~cm}$ also contained some detrital material. The basal core date of this continuous core is $2450 \pm 70$ RCYBP.

\section{Scholfield Creek Mouth Core - 331}

This core was taken at the mouth of Scholfield creek where it enters the Umpqua River $7 \mathrm{~km}(4.3 \mathrm{mi})$ due east of the ocean (figure 8).

Core 331 - This $300 \mathrm{~cm}$ core consists of muddy peat/peaty mud to a depth of $175 \mathrm{~cm}$. It is broken by a thin sand layer with sharp upper and lower contacts at a depth of $65 \mathrm{~cm}$. This sand is strongly suggestive of a tsunami layer. From $175 \mathrm{~cm}$ to the end of the core at $300 \mathrm{~cm}$ there is muddy sand.

\section{Scholfield Creek Cores - 301, 302, 303, 314}

These cores were taken from marshy areas along a meandering section of Scholfield Creek approximately $11 \mathrm{~km}$ $(6.7 \mathrm{mi}$.$) due east of the ocean (figure 8).$ 
Core 314- of the cores taken on Scholfield creek, this $400 \mathrm{~cm}$ long core is taken closest to the mouth of the creek where it enters the Umoqua River. From the surface to a depth of $110 \mathrm{~cm}$ there is muddy peat. The muddy peat tops a thick layer of peaty mud with gradual upper and lower contacts which extends to a depth of $290 \mathrm{~cm}$. From $290 \mathrm{~cm}$ to $320 \mathrm{~cm}$ there is slightly peaty mud with a gradual lower contact. At $320 \mathrm{~cm}$ there is a very sandy mud which continues to the end of the core at $400 \mathrm{~cm}$. This continuous core is characterized by muddy peat grading downward to a peaty mud. Core 303-This core was taken at the point where oar Creek enters Scholfield Creek. It is $200 \mathrm{~cm}$ long. From the surface to $75 \mathrm{~cm}$ in depth there is muddy peat. Peaty mud with gradual upper and lower contacts is seen from $75 \mathrm{~cm}$ to $165 \mathrm{~cm}$. From $165 \mathrm{~cm}$ to $175 \mathrm{~cm}$ there is slightly sandy mud with a gradual lower contact. The remainder of the core from $175 \mathrm{~cm}$ to the end at $200 \mathrm{~cm}$ consists of muddy sand.

Core 302 - This $300 \mathrm{~cm}$ long core was taken from a meandering portion of scholfield creek. It consists of peat from the surface downward to $25 \mathrm{~cm}$. From $25 \mathrm{~cm}$ to $60 \mathrm{~cm}$ is a muddy peat which grades into a peaty mud to a depth of $65 \mathrm{~cm}$. This peaty mud tops a mud layer which extends to $87 \mathrm{~cm}$ and has a sharp upper contact and gradual lower contact. From 87 $\mathrm{cm}$ to $500 \mathrm{~cm}$ there is peaty mud. The mud layer described above is most likely a cut and fill feature of the meandering 
stream. Discounting this feature, the entire core consists of varying degrees of peat.

Core 301- (figure 9) This core was taken 10 meters upstream from core 302 on the same meandering section of Scholfield Creek. This core is $415 \mathrm{~cm}$ long and contains peaty mud from the surface to $40 \mathrm{~cm}$. From $40 \mathrm{~cm}$ to $165 \mathrm{~cm}$ the core contains varying amounts of muddy peat, peaty mud, and slightly peaty mud. The peaty mud was sampled at a depth of $78 \mathrm{~cm}$ and dates at $400 \pm 60 \mathrm{RCYBP}$. At $165 \mathrm{~cm}$ there is mud which continues to a depth of $185 \mathrm{~cm}$. From $185 \mathrm{~cm}$ to $187 \mathrm{~cm}$ there is a sand lens with a sharp lower contact. The sand tops a layer of peaty mud which extends to a depth of $205 \mathrm{~cm}$. From $205 \mathrm{~cm}$ to $245 \mathrm{~cm}$ there is a mud layer with sharp upper and lower contacts. From $245 \mathrm{~cm}$ to the bottom of the core at $415 \mathrm{~cm}$ the core composition varies from peaty mud to slightly peaty mud with multiple sharp contacts at the points of variation. There is also some detrital material between 285 $\mathrm{cm}$ and $300 \mathrm{~cm}$. This material dated at 2,530 $\pm 80 \mathrm{RCYBP}$. This core is characterized by features typical of multiple stream cut and fill episodes. However, the $400 \pm 60$ RCYBP date of peaty mud coincides with other episodically buried peat in core 311 (within one standard deviation) where the peat dates at $310 \pm 50 \mathrm{RCYBP}$. From 310 to $330 \mathrm{~cm}$ the core contains a liquefaction feature ( see sketch figure 11). 


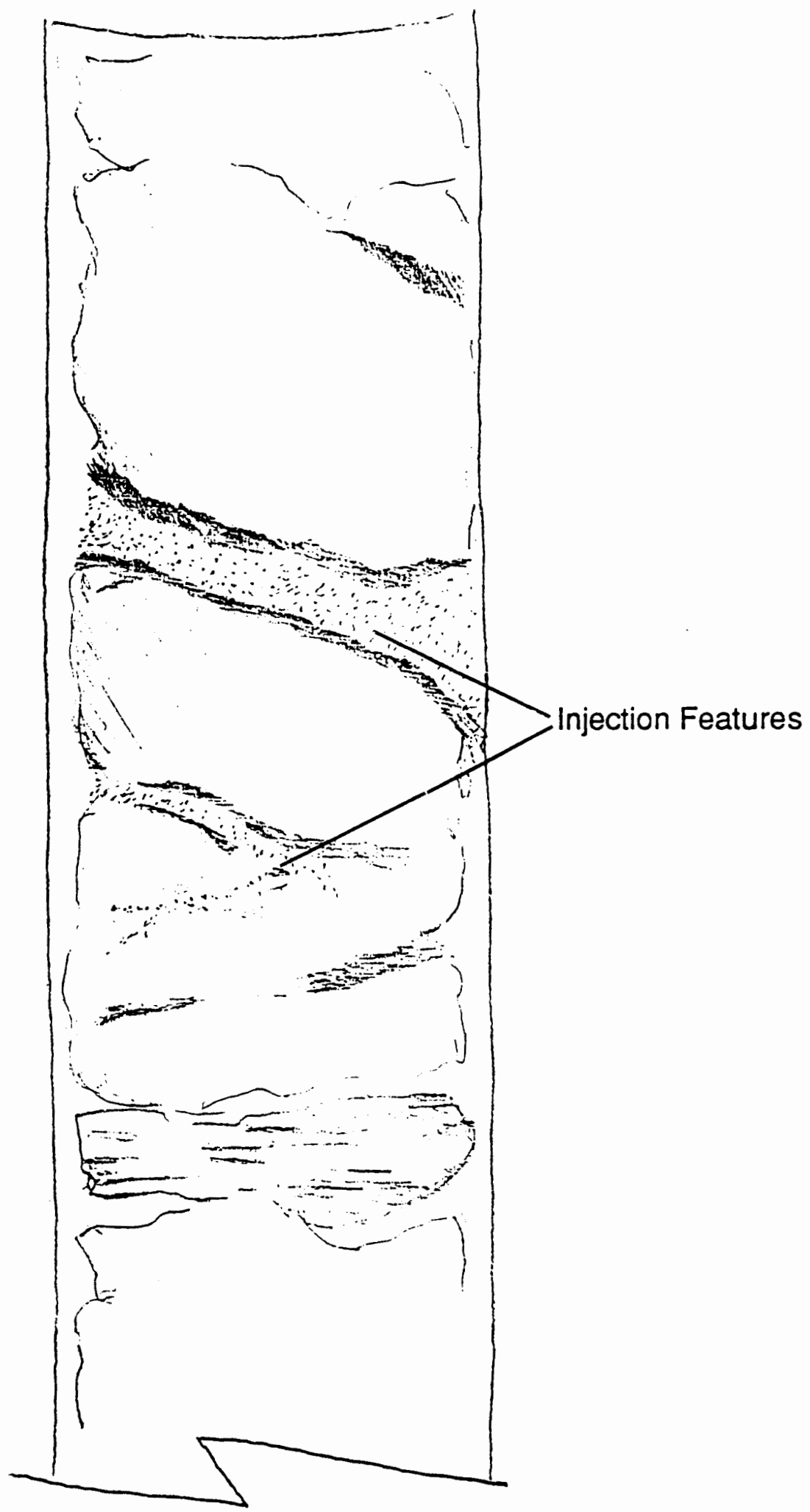

Figure 11. Drawing of an injection (liquefaction) feature found in Scholfield Creek core 301 . This injected silled feature is indicative of the strong ground motion associated with large seismic events. This feature is located between $310 \mathrm{~cm}$ and $330 \mathrm{~cm}$ depth. 
oar Creek Cores - 320, 321

These cores were taken $12 \mathrm{~km}(7.3 \mathrm{mi})$ due east of the ocean on Oar Creek (figure 8).

Core 321- (figure 9) This core was taken $1 \mathrm{~km}(0.61 \mathrm{mi}$ ) upstream from where oar creek flows into Scholfield Creek. The core is $500 \mathrm{~cm}$ long. The top of the core from the surface to $118 \mathrm{~cm}$ is peat. The peat tops a mud lens which has a gradual upper and sharp lower contact and extends to $148 \mathrm{~cm}$. From $148 \mathrm{~cm}$ to $152 \mathrm{~cm}$ the core contains detrital material. A peaty mud extends from $152 \mathrm{~cm}$ to $200 \mathrm{~cm}$. From $200 \mathrm{~cm}$ to $230 \mathrm{~cm}$ there is a peat with a gradual lower contact. This peat layer is dated at $1420 \pm 80$ RCYBP. The peat overlays a slightly peaty mud which continues to a depth of $260 \mathrm{~cm}$. From $260 \mathrm{~cm}$ to $265 \mathrm{~cm}$ there is muddy peat with a sharp upper contact and a gradual lower contact. At this point there is a $1 \mathrm{~cm}$ sand lens. From $266 \mathrm{~cm}$ to $312 \mathrm{~cm}$ there is a slightly peaty mud. Muddy peat with a sharp upper contact and a gradual lower contact is seen from $312 \mathrm{~cm}$ to $355 \mathrm{~cm}$. At $355 \mathrm{~cm}$ there is peaty mud with a gradual lower contact which extends to $385 \mathrm{~cm}$. From $385 \mathrm{~cm}$ to the end of the core at $500 \mathrm{~cm}$ there is slightly peaty mud. The mud lenses seen in this core are characteristic of stream cut and 
fill effects. The core is primarily continuous peaty material with the exception of these muddy lenses.

Core 320 - This core is $400 \mathrm{~cm}$ long and was taken $0.5 \mathrm{~km}$ $\{0.31 \mathrm{mi}$ ) south (upstream) of core 321 at the confluence of three small tributary creeks. It is characterized by a repeating pattern (21 layers) of cut and fill consisting of slightly peaty sandy muds, slightly sandy muds, and peaty muds.

\section{Butler Creek Cores $-311,312,313,334,333$}

The area where these cores were taken on Butler Creek is located $11 \mathrm{~km}(6.7 \mathrm{mi})$ due east of the ocean (figure 8). Bulter Creek is a stream with wide meanders which merges with the Smith River at the point where the Smith River flows into the Umpqua River. This area is an extensive, tidally influenced marsh.

Core 311- (figure 9) This core is $300 \mathrm{~cm}$ long. It consists of peat from the surface to $75 \mathrm{~cm}$ and contains a high concentration of sand, although not a true sand lens, between $65 \mathrm{~cm}$ and $75 \mathrm{~cm}$ down core. From $75 \mathrm{~cm}$ to $125 \mathrm{~cm}$ there is a muddy peat with gradual upper and lower contacts. At $125 \mathrm{~cm}$ there is a peaty mud with a gradual lower contact which continues to a depth of $240 \mathrm{~cm}$. The remainder of the core is mud from $240 \mathrm{~cm}$ to the bottom of the core at $300 \mathrm{~cm}$. 
A sample of muddy peat taken from the base of the sandy layer at $79 \mathrm{~cm}$ was AMS dated at 310 years \pm 50 . This sand layer is a candidate tsunami layer.

Core 312- From the surface of this $400 \mathrm{~cm}$ long core to $25 \mathrm{~cm}$ there is peat. The peat tops a layer of muddy peat with a gradual upper and lower contact to a depth of $55 \mathrm{~cm}$. At $55 \mathrm{~cm}$ to a depth of $68 \mathrm{~cm}$ there is peaty mud. From $68 \mathrm{~cm}$ to 110 there is muddy peat with a gradual upper contact and a sharp lower contact. From $110 \mathrm{~cm}$ to the end of the core at $400 \mathrm{~cm}$ there is a combination of mud and slightly muddy sand.

Core 313- From the surface to a depth of $15 \mathrm{~cm}$ this 285 $\mathrm{cm}$ long core consists of peat with a gradual lower contact. From $15 \mathrm{~cm}$ to $90 \mathrm{~cm}$ there is a muddy peat with a gradual lower contact. At $90 \mathrm{~cm}$ there is a peaty mud with a gradual lower contact. This peaty mud extends to a depth of $195 \mathrm{~cm}$. From $195 \mathrm{~cm}$ to the end of the core at $285 \mathrm{~cm}$ there is mud. Core 334- This core is $185 \mathrm{~cm}$ long. The top $30 \mathrm{~cm}$ of the core was not recovered. From $30 \mathrm{~cm}$ to $90 \mathrm{~cm}$ there is muddy peat with a gradual lower contact which grades into a peaty mud. The peaty mud continues down core to a depth of $128 \mathrm{~cm}$ and has a gradual lower contact. This peaty mud grades into a slightly peaty mud from $128 \mathrm{~cm}$ to the end of the core at $185 \mathrm{~cm}$.

Cores $311,312,313$, and 334 are continuous cores that grade downward to lesser amounts of peat. 
Core 333 - This $500 \mathrm{~cm}$ long core contains muddy peat and peaty mud from the surface to a depth of $125 \mathrm{~cm}$ where there is a gradual contact. This portion of the core is interrupted by a thin sand layer at $30 \mathrm{~cm}$ of depth and a $5 \mathrm{~cm}$ mud layer at $60 \mathrm{~cm}$ of depth. From $125 \mathrm{~cm}$ to $400 \mathrm{~cm}$ there is mud with a gradual lower contact. A sand layer with a gradual lower contact is seen from $400 \mathrm{~cm}$ to $440 \mathrm{~cm}$. From $440 \mathrm{~cm}$ to the end of the core at $500 \mathrm{~cm}$ there is sandy mud. The origins of the sand and mud layers seen in the upper 70 $\mathrm{cm}$ of this core are not known.

\section{Smith River Cores - 325, 329}

The Smith River flows into the Umpqua River at East Gardiner (Eigure 8).

Core 325- This core was taken from a marshy area where Franz Creek, a meandering stream, flows into Smith River 8.5 $\mathrm{km}$ ( $5.2 \mathrm{mi})$ due east of the ocean. This core is $500 \mathrm{~cm}$ long. The top of this core from the surface to a depth of $68 \mathrm{~cm}$ is muddy mud with a gradual lower contact. From $68 \mathrm{~cm}$ to $212 \mathrm{~cm}$ slightly peaty mud is seen. From 212 to $232 \mathrm{~cm}$ there is peaty mud with gradual upper and lower contacts. The lower 4 $\mathrm{cm}$ of this peaty mud contains some detrital material. At 232 cm there is slightly peaty mud which continues to a depth of $340 \mathrm{~cm}$. This slightly peaty mud tops a layer of muddy peat 
with a sharp upper contact and a gradual lower contact. It extends to a depth of $386 \mathrm{~cm}$. From $386 \mathrm{~cm}$ to $482 \mathrm{~cm}$ there is slightly peaty mud with a gradual lower contact. The bottom of the core is muddy peat from $482 \mathrm{~cm}$ to $500 \mathrm{~cm}$. The area where this core was taken has been affected by the meandering character of Franz Creek. It is possible that this core has been modified by stream cuts and daily tidal changes.

Core 329- This $500 \mathrm{~cm}$ long core was taken on the north bank of the Smith River $11.5 \mathrm{~km}(7.0 \mathrm{mi})$ due east of the ocean in an area subject to channel cutting and winter flooding. There is peaty mud with a gradual lower contact in the top portion of the core from the surface to a depth of $113 \mathrm{~cm}$. At this point the peaty mud grades into slightly peaty mud which extends to a depth of $162 \mathrm{~cm}$. From $162 \mathrm{~cm}$ to $190 \mathrm{~cm}$ a muddy peat with a sharp upper contact and a gradual lower contact is seen. From $190 \mathrm{~cm}$ to $200 \mathrm{~cm}$ there is peaty mud which has a gradual lower contact. It grades into a slightly peaty mud from $200 \mathrm{~cm}$ to $300 \mathrm{~cm}$. At $300 \mathrm{~cm}$ there is peaty mud with a sharp upper and gradual lower contact. This peaty mud extends to a depth of $325 \mathrm{~cm}$ at which point it grades into a slightly peaty mud to a depth of $361 \mathrm{~cm}$. From $361 \mathrm{~cm}$ to $420 \mathrm{~cm}$ there is peaty mud. Slightly peaty mud with a gradual lower contact is seen from $420 \mathrm{~cm}$ to $440 \mathrm{~cm}$. This slightly peaty mud grades into mud from $440 \mathrm{~cm}$ to the end of the core at $500 \mathrm{~cm}$. 


\section{otter slough Cores $-335,336,337$}

Otter Creek Slough is located $13 \mathrm{~km}(7.9 \mathrm{mi})$ due east of the ocean (figure 8). In this area Otter Creek has cut back and forth across the slough.

Core 335- This core was taken from a part of the slough somewhat protected from stream migration. It is $600 \mathrm{~cm}$ long. Muddy peat with a gradual lower contact is seen from the surface to a depth of $90 \mathrm{~cm}$. From $90 \mathrm{~cm}$ to $100 \mathrm{~cm}$ there is slightly peaty mud with a gradual lower contact. From $100 \mathrm{~cm}$ to $115 \mathrm{~cm}$ there is muddy peat with a gradual lower contact. At $115 \mathrm{~cm}$ is peaty mud which extends to a depth of $252 \mathrm{~cm}$. It has a gradual lower contact. Muddy peat with a gradual lower contact is evident from $252 \mathrm{~cm}$ to $288 \mathrm{~cm}$. From $288 \mathrm{~cm}$ to $370 \mathrm{~cm}$ there is peaty mud with a gradual lower contact. There is muddy peat with a gradual lower contact from $370 \mathrm{~cm}$ to $390 \mathrm{~cm}$. From $390 \mathrm{~cm}$ to $467 \mathrm{~cm}$ there is peaty mud with a gradual lower contact. It contains some detrital material from $430 \mathrm{~cm}$ and $437 \mathrm{~cm}$. At $467 \mathrm{~cm}$ there is slightly peaty mud with a gradual lower contact. This slightly peaty mud extends down core to $540 \mathrm{~cm}$ where it grades into peaty mud to the bottom of the core at $600 \mathrm{~cm}$. This core consists of 30 to 70 percent peat throughout. 
Core 336- This core was taken next to the otter creek channel. It is $300 \mathrm{~cm}$ long. The top of the core contains muddy peat from the surface to a depth of $18 \mathrm{~cm}$ where there is a gradual lower contact. From $18 \mathrm{~cm}$ to $300 \mathrm{~cm}$ there is slightly muddy peat containing some sand.

Core 337- (figure 9) This core was taken from a low wetland area on the east side of otter slough near the point where a small tributary flows into the slough. It is $465 \mathrm{~cm}$ long. All contacts in the core are gradual. It consists of muddy peat from the surface to a depth of $115 \mathrm{~cm}$ where it grades into peaty mud. The peaty mud extends to $162 \mathrm{~cm}$ where it grades into slightly peaty mud to a depth of $255 \mathrm{~cm}$. At $255 \mathrm{~cm}$ the slightly peaty mud grades into muddy peat which continues to a depth of $288 \mathrm{~cm}$. The top portion of this muddy peat dates at $2150 \pm 80$ RCYBP. From $288 \mathrm{~cm}$ to $370 \mathrm{~cm}$ the muddy peat grades into a slightly peaty mud. At $370 \mathrm{~cm}$ the slightly peaty mud grades into muddy peat. This muddy peat dates at $3140 \pm 70$ RCYBP. At $390 \mathrm{~cm}$ the muddy peat grades into peaty mud. This peaty mud continues from $390 \mathrm{~cm}$ to the end of the core at $465 \mathrm{~cm}$. Between $427 \mathrm{~cm}$ and $432 \mathrm{~cm}$ the peaty mud contains some detrital material.

\section{Dean Creek Cores - 322, 323, 332}

Dean Creek is $16.5 \mathrm{~km}$ (10.1 $\mathrm{mi}$ ) due east of the ocean. It flows directly into the Umpqua River (figure 8). Cores 
322 and 332 contain buried marsh units with only sharp upper contacts and gradual lower contacts. This is a distinctive characteristic of rapid marsh/wetland burial episodes.

Core 323- This core was taken at the location where Hakki Creek flows into Dean Creek on the west side of the creeks. It is $300 \mathrm{~cm}$ long. Peaty mud is seen in the top portion of the core from the surface to $53 \mathrm{~cm}$. There is a gradual lower contact. From $53 \mathrm{~cm}$ to $72 \mathrm{~cm}$ there is slightly peaty mud. At $72 \mathrm{~cm}$ peaty mud extends to $100 \mathrm{~cm}$. It has a sharp upper contact and gradual lower contact. This peaty mud contains a small lens of slightly peaty mud from $85 \mathrm{~cm}$ to $87 \mathrm{~cm}$. At $100 \mathrm{~cm}$ the peaty mud grades into slightly peaty mud which extends to $175 \mathrm{~cm}$. At $130 \mathrm{~cm}$ to $175 \mathrm{~cm}$ small amounts of sand appears in the slightly peaty mud. The remainder of the core from $175 \mathrm{~cm}$ to $300 \mathrm{~cm}$ there is muddy sand.

Core 332- (figure 9) This vibra-core was taken $0.5 \mathrm{~km}$ $(0.31 \mathrm{mi})$ upstream from the point where Hakki Creek flows into Dean Creek on the south side of Dean Creek. It is 265 $\mathrm{cm}$ long. From the surface to a depth of $35 \mathrm{~cm}$ the core contains peaty mud with a gradual lower contact. Mud is evident from $35 \mathrm{~cm}$ to $72 \mathrm{~cm}$. At $72 \mathrm{~cm}$ there is muddy peat with a sharp upper contact and a gradual lower contact. This muddy peat is dated at $1270 \pm 90$ RCYBP. The muddy peat extends to $83 \mathrm{~cm}$. From $83 \mathrm{~cm}$ to $87 \mathrm{~cm}$ there is peaty mud 
with a gradual lower contact. Slightly peaty mud with a gradual lower contact is seen from $87 \mathrm{~cm}$ to $95 \mathrm{~cm}$. From 95 $\mathrm{cm}$ to $125 \mathrm{~cm}$ mud is found. At $125 \mathrm{~cm}$ there is peaty mud with a sharp upper contact and a gradual lower contact. This peaty mud extends to $145 \mathrm{~cm}$ and dates at $2820 \pm 70$ RCYBP. Slightly peaty mud is evident from $145 \mathrm{~cm}$ to $175 \mathrm{~cm}$. At 175 $\mathrm{cm}$ there is peaty mud with a sharp upper contact and a gradual lower contact. The peaty mud dates at $2960 \pm 60$ RCYBP. It continues to a depth of $220 \mathrm{~cm}$. From $220 \mathrm{~cm}$ to $237 \mathrm{~cm}$ slightly peaty mud containing small amounts of sand is evident. At $237 \mathrm{~cm}$ peaty mud with a sharp upper contact and a gradual lower contact is seen. It continues to a depth of $250 \mathrm{~cm}$. From $250 \mathrm{~cm}$ to the end of the core at $265 \mathrm{~cm}$ there is sand. This core contains four distinct buried peaty units delineated by the sharp upper contacts.

core 322- This core was taken $1 \mathrm{~m}$ from core 332 and contains exactly the same stratigraphy.

\section{North Bank Umpqua River Cores - 316, 317}

These cores were taken from a lowland meadow on the north side of the Umpqua River $19 \mathrm{~km}$ (11.6 $\mathrm{mi}$ ) due east of the ocean. This is an area affected by channel variations of the Umpqua River (figure 8). 
Core 316- This $500 \mathrm{~cm}$ long core consists primarily of peaty mud from the surface to $105 \mathrm{~cm}$ of depth, at $170 \mathrm{~cm}$ to $185 \mathrm{~cm}$, at $235 \mathrm{~cm}$ to $266 \mathrm{~cm}$, at $365 \mathrm{~cm}$ to $387 \mathrm{~cm}$, and at 425 $\mathrm{cm}$ to the end of the core. These peaty muds are interspersed with muds and sandy muds which contain small amounts of detrital material. The last $15 \mathrm{~cm}$ of the core is peaty mud mixed with sand. There is one sharp contact at a depth of 170 $\mathrm{cm}$.

Core 317 - This core is $340 \mathrm{~cm}$ long. The top portion of the core, from the surface to a depth of $75 \mathrm{~cm}$, was not recovered. From $75 \mathrm{~cm}$ to $310 \mathrm{~cm}$ the core contains mud grading downward into slightly peaty mud which contains small amounts of sand and detrital material. At $310 \mathrm{~cm}$ there is peaty mud with a sharp upper and sharp lower contacts. The peaty mud extends to a depth of $327 \mathrm{~cm}$. The peaty mud tops a thin sand layer. At $329 \mathrm{~cm}$ there is muddy peat with a sharp upper contact. This muddy peat extends to the bottom of the core.

\section{Earvey Creek Cores - 315, 318}

These cores were taken from a low meadow $21 \mathrm{~km}(12.8 \mathrm{mi})$ due east of the ocean in the area where Harvey Creek flows into the Umpqua River (figure 8). 
Core 318- The top of this $400 \mathrm{~cm}$ long core contains peaty mud from the surface to a depth of $70 \mathrm{~cm}$. From $70 \mathrm{~cm}$ to the bottom of the core at $400 \mathrm{~cm}$ there is slightly peaty mud with layers of detrital material at $137 \mathrm{~cm}, 200 \mathrm{~cm}$ and $285 \mathrm{~cm}$.

Core 315- This core is $400 \mathrm{~cm}$ long. It consists of muddy peat from the surface to a depth of $55 \mathrm{~cm}$ and has a gradual lower contact. From $55 \mathrm{~cm}$ to $95 \mathrm{~cm}$ peaty mud with a sharp lower contact is seen. At $95 \mathrm{~cm}$ there is mud which extends to a depth of $140 \mathrm{~cm}$. From $140 \mathrm{~cm}$ to $180 \mathrm{~cm}$ there is a slightly peaty mud with gradual upper and lower contacts. There is a thin layer of peaty mud from $180 \mathrm{~cm}$ to $185 \mathrm{~cm}$ which has a sharp lower contact. At $185 \mathrm{~cm}$ there is mud which continues to a depth of $210 \mathrm{~cm}$. From $210 \mathrm{~cm}$ to $290 \mathrm{~cm}$ peat with gradual upper and lower contacts is seen. Peaty mud with a gradual lower contact is evident from $290 \mathrm{~cm}$ to $335 \mathrm{~cm}$. From $335 \mathrm{~cm}$ to $345 \mathrm{~cm}$ there is slightly peaty mud with a gradual lower contact. From $345 \mathrm{~cm}$ to the end of the core at $400 \mathrm{~cm}$ there is peaty mud.

It is noted that progressing east from Oar Creek in the Umpqua River area, the incidence of sharp upper peat contacts increases suggesting sudden subsidence. 
TABLE VI

SUMMARY OF UMPQUA RIVER AREA C-14 DATES

\begin{tabular}{|c|c|c|}
\hline CORE\# & DEPTH & $\underline{A G E}$ \\
\hline 339 & $\begin{array}{r}89 \mathrm{~cm} \\
179 \mathrm{~cm} \\
225 \mathrm{~cm}\end{array}$ & $\begin{array}{l}1040 \pm 60 \text { yrs } \\
1630 \pm 60 \text { yrs } \\
1850 \pm 60 \text { yrs }\end{array}$ \\
\hline 328 & $255 \mathrm{~cm}$ & $2450 \pm 70$ yrs \\
\hline 301 & $\begin{array}{r}78 \mathrm{~cm} \\
290 \mathrm{~cm}\end{array}$ & $\begin{array}{l}400 \pm 50 \text { yrs } \\
2530 \pm 80 \text { yrs }\end{array}$ \\
\hline 311 & $79 \mathrm{~cm}$ & $310 \pm 50$ yrs (AMS) \\
\hline 321 & $205 \mathrm{~cm}$ & $1420 \pm 80 \mathrm{yrs}$ \\
\hline 337 & $\begin{array}{l}260 \mathrm{~cm} \\
375 \mathrm{~cm}\end{array}$ & $\begin{array}{l}2150 \pm 80 \text { yrs } \\
3140 \pm 70 \text { Yrs }\end{array}$ \\
\hline 332 & $\begin{array}{l}76 \mathrm{~cm} \\
130 \mathrm{~cm} \\
180 \mathrm{~cm}\end{array}$ & $\begin{array}{l}1270 \pm 90 \text { yrs } \\
2820 \pm 70 \text { yrs } \\
2960 \pm 60 \text { yrs }\end{array}$ \\
\hline
\end{tabular}

\section{DIATOMS}

Two cores taken from the Umpqua River area were analyzed for the presence of marine/brackish water marker diatoms. These are core 332 at Dean Creek and core 328 at Providence Creek (TABLE VII).

Core 332 Dean Creek- This core was taken $16.5 \mathrm{~km}$ $(10.1 \mathrm{mi})$ due east of the ocean. It contains evidence of four marsh burial events. Three samples taken from the core were analyzed for marker diatoms and were also radiocarbon 
TABLE VII

UMPQUA MARINE/BRACKISH DIATOM SAMPLING CCUNTS

\begin{tabular}{|c|c|c|c|c|c|c|}
\hline \multirow{4}{*}{$\begin{array}{c}\text { MARINE/BRACKISH } \\
\text { DIATOMS } \\
\text { Whole Frustules only }\end{array}$} & \multicolumn{6}{|c|}{ UMPQUA RIVER - Marine Diatom Counts } \\
\hline & \multicolumn{2}{|c|}{ Core number 332} & \multicolumn{4}{|c|}{ Core number 328} \\
\hline & COUNT \% Total & COUNT \% Total & COUNT & \% Total & COUNT & $\%$ Total \\
\hline & Mu1 Mud @ $54 \mathrm{~cm}$ & \multirow[t]{2}{*}{ Mu1 Peat@ @ $76 \mathrm{~cm}$} & \multicolumn{4}{|c|}{ Sample $1 @ 54 \mathrm{~cm} 1$ sample $2 @ 77 \mathrm{~cm}$} \\
\hline Actinoptychus undulatus & & & 2 & $2.0 \%$ & 1 & $6.0 \%$ \\
\hline Coscinodiscus Sp. & Mostly Fresh Water & Mostly Fresh Water & 50 & $46.0 \%$ & 4 & $23.0 \%$ \\
\hline Stephanodiscus sp. & Oistinct Absence & & & & & \\
\hline Trigonium $\mathbf{s p}$ & of Marker Diatoms & & & & & \\
\hline Cocconeis sp & & $50.0 \%$ & 17 & $15.0 \%$ & 4 & $23.0 \%$ \\
\hline Diploneis smithii & & $50.0 \%$ & 21 & $19.0 \%$ & 3 & $18.0 \%$ \\
\hline Diploneis interrupta & & & 10 & $9.0 \%$ & 3 & $18.0 \%$ \\
\hline \multicolumn{7}{|l|}{ Nitzschia punctata } \\
\hline Opephora marina & & & & & 1. & $6.0 \%$ \\
\hline Rhopalodia sp. & & & 8 & $7.0 \%$ & 1 & $6.0 \%$ \\
\hline Surirella sp. & & & $2 \vdots$ & $2.0 \%$ & & \\
\hline \multirow{3}{*}{ TOTAL } & n.a. & $100.0 \%$ & 110 & $100.0 \%$ & 17 & $100.0 \%$ \\
\hline & & & & & & \\
\hline & Mu2Mud@113cm & Mu2 Peat@125cm & Sample 3 & $@ 113 \mathrm{~cm}$ ! & Sample 4 & $@ 122 \mathrm{~cm}$ \\
\hline Actinoptychus undulatus & & & & & 3 & $3.0 \%$ \\
\hline Coscinodiscus sp. & All Fresh Water & All Fresh Water & $7:$ & $19.0 \%$ & 41 & $39.0 \%$ \\
\hline Stephanodiscus sp. & Distinct Absence & Distinct Absence & & & & \\
\hline Trigonium sp. & of Marker Diatoms & of Marker Diatoms & & & & \\
\hline Cocconeis SP & & & 8 & $22.0 \%$ & 14 & $13.0 \%$ \\
\hline Diploneis smithii & & & & & 12 & $11.0 \%$ \\
\hline Diploneis interrupta & & & 2 & $5.0 \%$ & 12 & $11.0 \%$ \\
\hline \multicolumn{7}{|l|}{ Nitzschia punctata } \\
\hline Opephora marina & & & $2 \vdots$ & $5.0 \%$ & & \\
\hline Rhopalodia sp. & & & $18:$ & $49.0 \%$ & 13 & $12.0 \%$ \\
\hline Surirella sp. & & & & & 11 & $11.0 \%$ \\
\hline TOTAL & All FW's & All FW's & 37 & $100.0 \%$ & 105 & $100.0 \%$ \\
\hline \multirow{2}{*}{ (1) } & & & & & & \\
\hline & Mu3 Mud@168cm & Mu3 Peat @ 180cm & Sample 5 & @ $168 \mathrm{~cm}$ & Sample 6 & $@ 175 \mathrm{~cm}$ \\
\hline Actinoptychus undulatus & & & 1 & $2.0 \%$ & $2 \vdots$ & $3.0 \%$ \\
\hline Coscinodiscus sp. & All Fresh Water & Mostly Fresh Waten & 27 & $51.0 \%$ & 25 & $43.0 \%$ \\
\hline Stephanodiscus sp. & Distinct Absence & Distinct Absence & & & & \\
\hline Trigonium sp. & of Marker Diatoms & of Marker Diatoms & $\ldots$ & & & \\
\hline Cocconeis sp & & & 7 & $13.0 \%$ & 8 & $14.0 \%$ \\
\hline Diploneis smithii & & & 1 & $2.0 \%$ & 1 & $2.0 \%$ \\
\hline Diploneis interrupta & & & 1 & $2.0 \%$ & 1 & $2.0 \%$ \\
\hline \multicolumn{7}{|l|}{ Nitzschia punctata } \\
\hline \multicolumn{7}{|l|}{ Opephora marina } \\
\hline Rhopalodia sp. & & & 10 & $19.0 \%$ & 16 & $27.0 \%$ \\
\hline Surirella sp. & & & 6 & $11.0 \%$ & 5 & $9.0 \%$ \\
\hline TOTAL & All FW's: & n.a. & 53 & $100.0 \%$ & 58 & $100.0 \%$ \\
\hline
\end{tabular}


dated. The remaining samples were analyzed for marker diatoms but were not dated (Table VII). The samples were taken down core from mud at $54 \mathrm{~cm}$, peat at $76 \mathrm{~cm}$ (this sample is dated at $1270 \pm 90$ RCYBP), mud at $113 \mathrm{~cm}$, peat at $125 \mathrm{~cm}$ (this sample was dated at $2820 \pm 70$ RCYBP), mud at $168 \mathrm{~cm}$, and peat at $180 \mathrm{~cm}$ (this sample was dated at $2960 \pm 60$ RCYBP). With the exception of the sample at $76 \mathrm{~cm}$ which contained two marine/brackish water marker diatoms, the remaining samples showed a complete absence of all marine/brackish water marker diatoms. The almost complete absence of these marine/brackish water diatoms and the distance that the core was taken from the ocean are factors consistent with studies which indicate that counts of marine/brackish water diatoms decrease dramatically where water salinity is $5 \%$ or less. The purpose of testing this core is to establish whether marine flow increased to this distance upstream during the subsidence (mud layer) periods. As noted, no marine/brackish water diatoms are found.

Core 328 Providence Creek- This core consists of continuous peat and is $265 \mathrm{~cm}$ long. The basal core date is $2450 \pm 70$ RCYBP. This core was sampled for diatom analysis at approximately the same depths as core 332 (Table VII). All six samples contain a large number of marine/brackish water marker diatom assemblages. These high counts suggest that the water salinity has consistently remained above $5 \%$. 
This also indicates that the marsh at this site never reached supratidal (freshwater) elevations.

\section{COOS BAY}

Coos Bay is located between UTM4790000 mN and UTM4817000 $\mathrm{mN}$. The study area extends inland approximately $24 \mathrm{~km}(14.6$ mi) due east of the ocean. Recent work in this area has confirmed the landward termination of the onshore fold/fault belt 100-110 km from the trench near catching Slough in coos Bay (Black, 1993). Seventy-eight cores were taken from this area (figure 12). Of these seventy-eight cores, eight were radiocarbon dated (figure 13 ).

\section{Northern Area}

The northern area of coos Bay extends from approximately U'TM4809500 mN to UTM4817000 mN and includes North Slough, Hauser Slough, Haynes Inlet, Palouse Slough, and Kentuck Slough. Twenty-five cores were taken in the northern area (figure 12). The area extends inland $13 \mathrm{~km}(7.9 \mathrm{mi})$ due east of the ocean. 


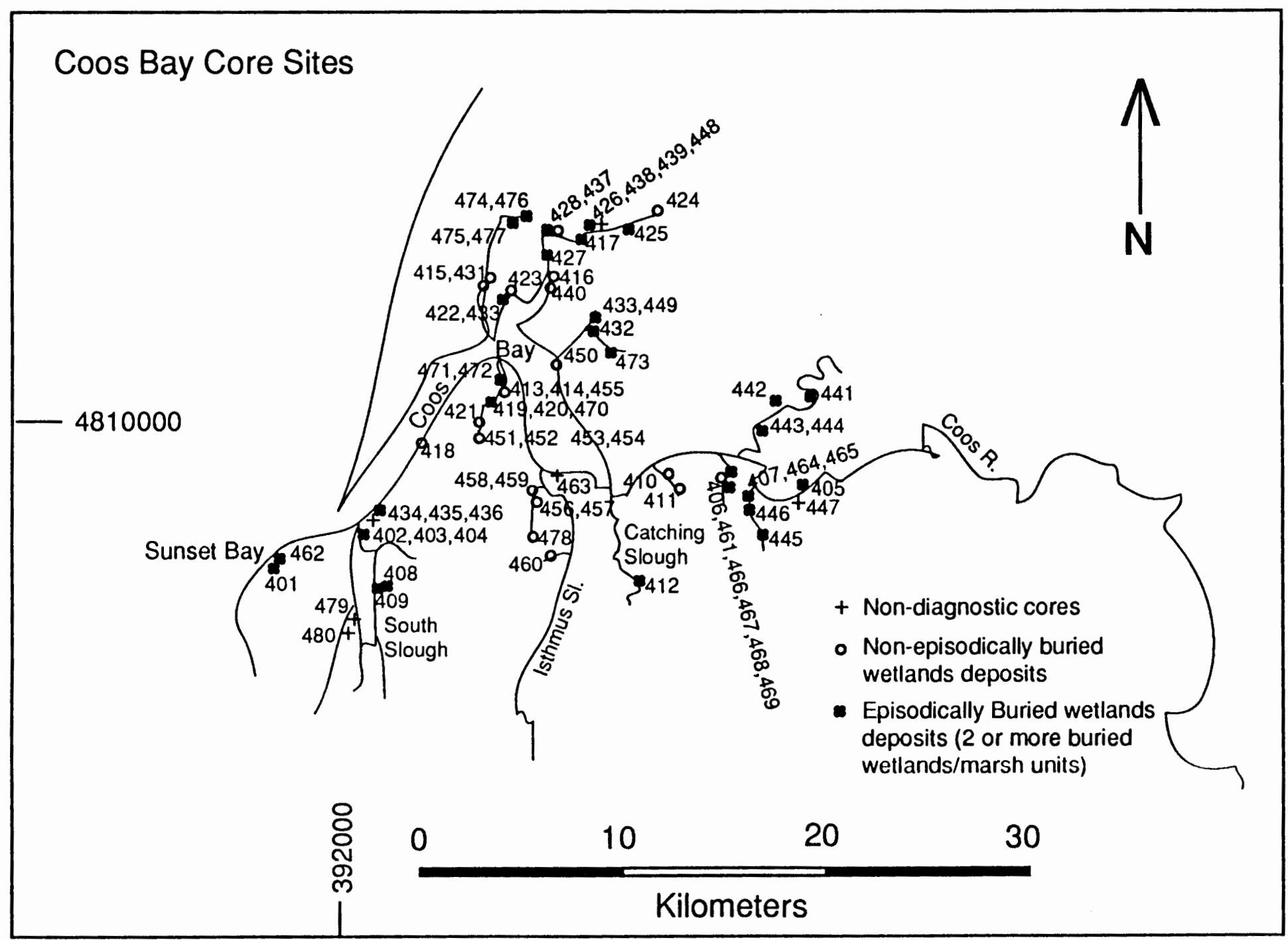

Figure 12. Coos Bay area core location map. Sites included tidal marshes, low lying pastures, and tidally influenced tributary streams of the Coos River, Coos Bay area. 


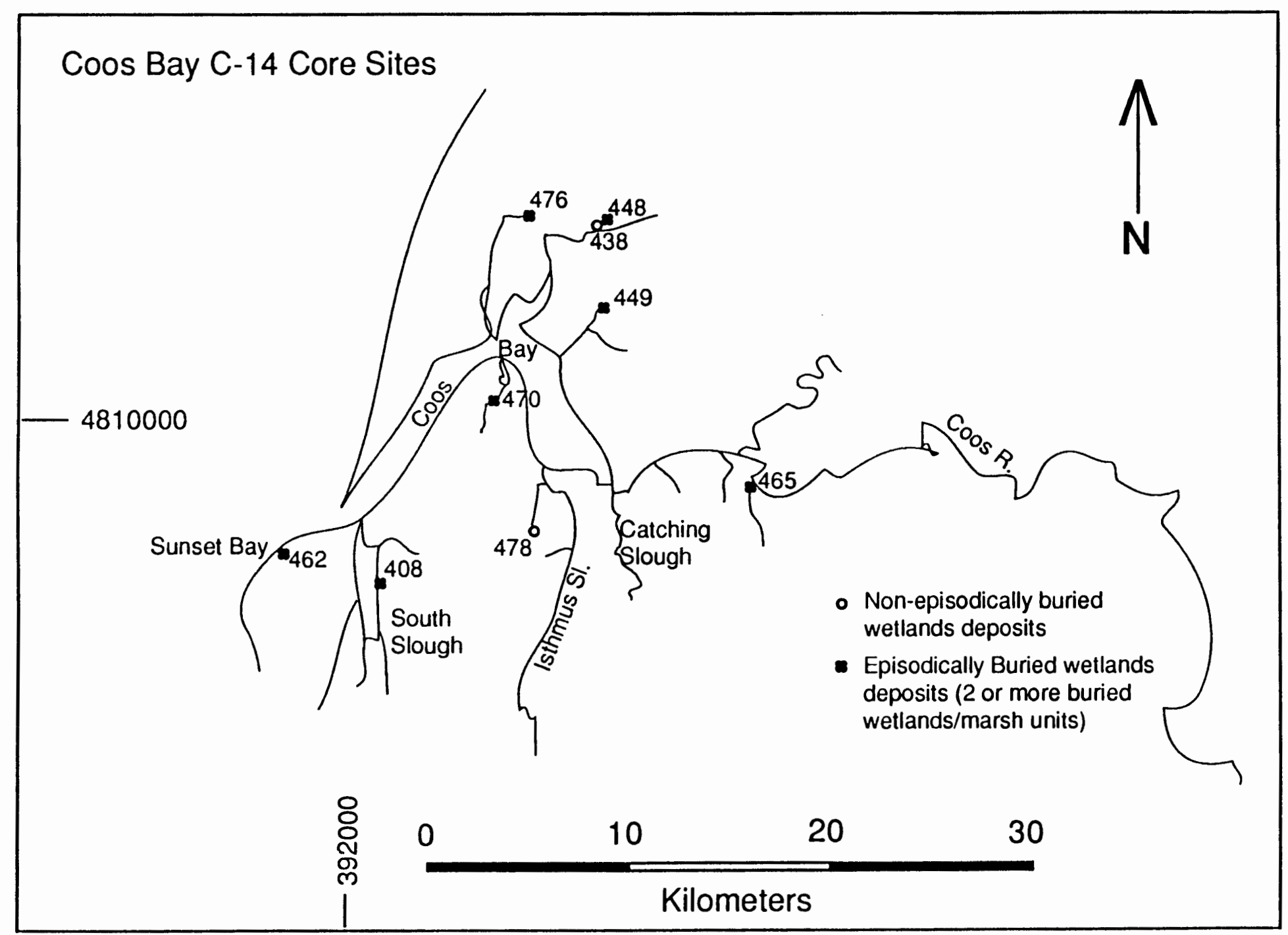

Figure 13. Coos Bay study area C-14 dated cores - Site Map. 
North Slough Cores - 415, 431

These cores were taken from a tidal marsh on the east side of North Slough approximately $50 \mathrm{~m}$ west of Highway 101 and $4 \mathrm{~km}(2.4 \mathrm{mi})$ due east of the ocean (figure 12).

Core 415- This core is $200 \mathrm{~cm}$ long. All contacts are gradual transitions. The top portion of the core contains peat from the surface to a depth of $40 \mathrm{~cm}$. From $40 \mathrm{~cm}$ to 65 $\mathrm{cm}$ there is peaty mud. At $65 \mathrm{~cm}$ the peaty mud grades into muddy peat which extends to $90 \mathrm{~cm}$. Peat is evident from 90 $\mathrm{cm}$ to $138 \mathrm{~cm}$. From $138 \mathrm{~cm}$ to $170 \mathrm{~cm}$ slightly sandy peaty mud is seen. At $170 \mathrm{~cm}$ this grades into slightly sandy muddy peat which continues to a depth of $185 \mathrm{~cm}$. From $185 \mathrm{~cm}$ to the end of the core at $200 \mathrm{~cm}$ muddy sand is present.

Core 431- This core was taken $200 \mathrm{~m}$ north of core 415 . It is a $240 \mathrm{~cm}$ Iong core and contains peat from the surface to a depth of $50 \mathrm{~cm}$. At $50 \mathrm{~cm}$ the peat grades into muddy peat which continues to a depth of $140 \mathrm{~cm}$. From $140 \mathrm{~cm}$ to $192 \mathrm{~cm}$ peaty mud is present. The remainder of the core, from $192 \mathrm{~cm}$ to the bottom at $240 \mathrm{~cm}$ there is sand. All of the contacts are gradual transitions. 
Hauser Slough Cores $-474,475,476,477$

Hauser slough is a low lying marsh area that is now controlled by a tidal gate (i.e. tidal flooding is prohibited by the tidal gate). It is $4.5 \mathrm{~km}(2.7 \mathrm{mi})$ due east of the ocean. All of these cores were taken on the south side of the slough (figure 12).

Core 474- This core is $400 \mathrm{~cm}$ long. The top $10 \mathrm{~cm}$ of the core was not recovered. From $10 \mathrm{~cm}$ to $25 \mathrm{~cm}$ there is muddy peat with a gradual lower contact. At $25 \mathrm{~cm}$ this muddy peat grades into a peaty mud. The nature of the lower contact of this peaty mud is unknown because the portion of the core between $40 \mathrm{~cm}$ and $75 \mathrm{~cm}$ was not recovered (this portion slopped away). From $75 \mathrm{~cm}$ to $120 \mathrm{~cm}$ muddy peat is evident. It gradually grades into peaty mud which continues to a depth of $145 \mathrm{~cm}$. This grades into a slightly peaty mud to $160 \mathrm{~cm}$. At this point the slightly peaty mud grades into mud to a depth of $203 \mathrm{~cm}$. From $203 \mathrm{~cm}$ to $255 \mathrm{~cm}$ there is peat with a sharp upper and sharp lower contact. At $255 \mathrm{~cm}$ a slightly peaty mud extends to $270 \mathrm{~cm}$. The peaty mud has a gradual lower contact and grades into mud which extends down to 338 $\mathrm{cm}$. From $338 \mathrm{~cm}$ to $360 \mathrm{~cm}$ there is sandy mud with sharp upper and lower contacts. From $360 \mathrm{~cm}$ to the end of the core 
at $400 \mathrm{~cm}$ there is sand. This core shows at least one burial event at a depth of $203 \mathrm{~cm}$.

Core 475 - This core was taken $0.3 \mathrm{~km}(0.18 \mathrm{mi})$ southwest of core 474 . It is $380 \mathrm{~cm}$ long core and contains muddy peat from the surface to a depth of $35 \mathrm{~cm}$. The lower contact is gradual. From $35 \mathrm{~cm}$ to $48 \mathrm{~cm}$ there is peaty mud with a gradual lower contact. The peaty mud grades into slightly peaty mud which extends down to $69 \mathrm{~cm}$. At $69 \mathrm{~cm}$ muddy peat with sharp upper and lower contacts is evident. This muddy peat extends to a depth of $82 \mathrm{~cm}$. From $82 \mathrm{~cm}$ to $130 \mathrm{~cm}$ there is slightly peaty mud with a gradual lower contact. It grades into a peaty mud which has a gradual lower contact at $162 \mathrm{~cm}$. Mud is seen from $162 \mathrm{~cm}$ to $195 \mathrm{~cm}$. The bottom $5 \mathrm{~cm}$ of this mud contains small amounts of sand. From $195 \mathrm{~cm}$ down to $253 \mathrm{~cm}$ there is muddy peat with a sharp upper contact and a gradual lower contact. It grades into slightly peaty mud which has a gradual lower contact at $300 \mathrm{~cm}$. From $300 \mathrm{~cm}$ to $342 \mathrm{~cm}$ there is mud. At $342 \mathrm{~cm}$ muddy sand is evident. It has a sharp upper contact and extends to the bottom of the core at $380 \mathrm{~cm}$. This core contains evidence of two buried marsh units with distinct sharp upper contacts at depths of $69 \mathrm{~cm}$ and $195 \mathrm{~cm}$.

Core 477- This $385 \mathrm{~cm}$ long core was taken $100 \mathrm{~m}$ south of core 475. The top of the core to a depth of $18 \mathrm{~cm}$ was not recovered. From $18 \mathrm{~cm}$ to $30 \mathrm{~cm}$ there is peaty mud with a gradual lower contact. It grades into slightly peaty mud 
which continues to $40 \mathrm{~cm}$. Muddy peat with a sharp upper contact and a gradual lower contact is seen from $40 \mathrm{~cm}$ down to $54 \mathrm{~cm}$. The muddy peat grades into peaty mud which has a gradual lower contact at $60 \mathrm{~cm}$. From $60 \mathrm{~cm}$ to $73 \mathrm{~cm}$ there is slightly peaty mud. At $73 \mathrm{~cm}$ muddy peat with a sharp upper and a gradual lower contact at $90 \mathrm{~cm}$ is evident. It grades into peaty mud. The peaty mud is seen to a depth of $108 \mathrm{~cm}$ and also has a gradual lower contact. From $108 \mathrm{~cm}$ to $142 \mathrm{~cm}$ there is slightly peaty mud. At $142 \mathrm{~cm}$ peat with a sharp upper contact and gradual lower contact is evident. At 187 $\mathrm{cm}$ the peat grades into muddy peat which extends to $218 \mathrm{~cm}$ where the contact is gradual. From $218 \mathrm{~cm}$ to $240 \mathrm{~cm}$ slightly peaty mud is found. The slightly peaty mud has a gradual lower contact and grades into mud which continues to a depth of $312 \mathrm{~cm}$. The portion of the core between $142 \mathrm{~cm}$ and $312 \mathrm{~cm}$ of depth is significant in that it represents the growth from a low intertidal colonizing marsh environment at $312 \mathrm{~cm}$ which, over time, evolved into a supratidal very high marsh or forested area as seen at $142 \mathrm{~cm}$ depth. The mud grades into muddy sand which extends to the end of the core at 385 $\mathrm{cm}$. This core contains evidence of three abruptly buried peats at depths of $30 \mathrm{~cm}, 73 \mathrm{~cm}$, and $142 \mathrm{~cm}$.

Core 476 (figure 14)- This vibra-core was taken within 2 $m$ of core 474 . It is $275 \mathrm{~cm}$ long. The top portion of this core from the surface down to $40 \mathrm{~cm}$ was not recovered. From $40 \mathrm{~cm}$ down to $65 \mathrm{~cm}$ there is peaty mud with a gradual lower 
COOS BAY CORES (Northem area)

Radiocarbon dates (C-14 AGE YRS B.P. $\pm 1 \sigma$ )

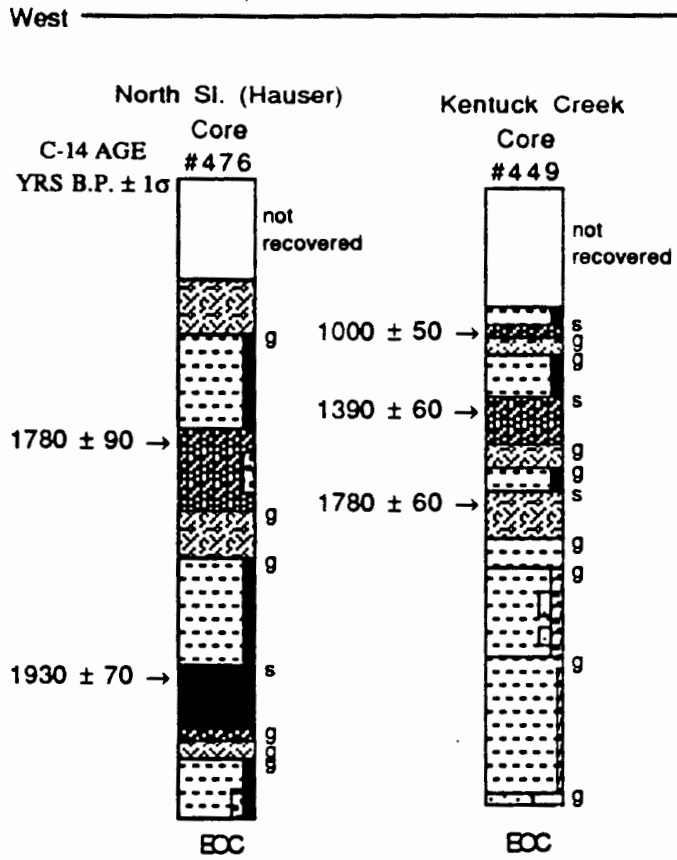

\section{Palouse Creek \\ Core}

\#438

要然

9

ss:

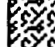

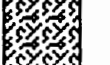

sos

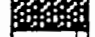

$\because \because-1$

\section{乎}

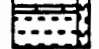

$\mathrm{BOC}$
$1800 \pm 60 \rightarrow$

Palouse Creek

Core

Core
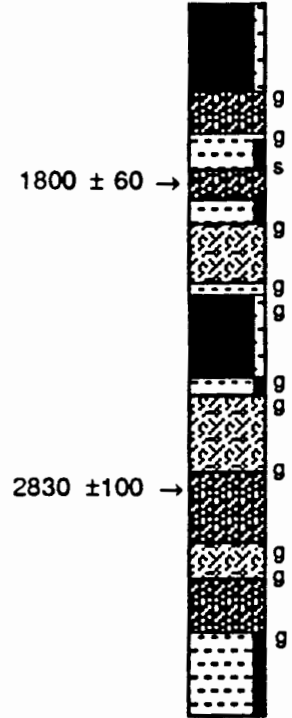

$B O C$
East

Vertical

Scale

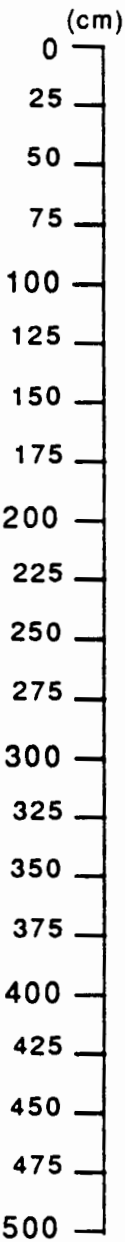

Figure 14. Coos Bay (Northern area) radiocarbon dated cores. Elevation corrections for the tops of cores taken in this northern Coos bay area were typically between $-0.2 \mathrm{~m}$ and $-2.5 \mathrm{~m}$ below mean sea level (low marsh to barren tidal flat, intertidal to low intertidal). See appendix $B$ for elevation range and Coos Bay core map for location of northern core sites. 
contact. The peaty mud grades into slightly peaty mud which extends down to $108 \mathrm{~cm}$. At $108 \mathrm{~cm}$ there is muddy peat with a sharp upper contact and a gradual lower contact. It contains some detrital material between $115 \mathrm{~cm}$ and $130 \mathrm{~cm}$. The upper $10 \mathrm{~cm}$ of this muddy peat dates at $1780 \pm 90$ RCYBP. At $140 \mathrm{~cm}$ there is peaty mud with a gradual lower contact. It extends down to $161 \mathrm{~cm}$. At $161 \mathrm{~cm}$ the peaty mud grades into slightly peaty mud which continues to a depth of $207 \mathrm{~cm}$. From $207 \mathrm{~cm}$ down to $235 \mathrm{~cm}$ there is peat which has a sharp upper contact and gradual lower contact. This peat dates at $1930 \pm 70$ RCYBP. The peat grades into a thin layer of muddy peat which has a gradual lower contact at $238 \mathrm{~cm}$. From $238 \mathrm{~cm}$ to $245 \mathrm{~cm}$ peaty mud with a gradual lower contact is seen. The peaty mud grades into slightly muddy peat which contains some detrital material and extends to the bottom of the core at $275 \mathrm{~cm}$. This core contains evidence of two distinct episodically buried peats at depths of $108 \mathrm{~cm}$ and $207 \mathrm{~cm}$.

\section{Haynes Inlet Cores $=416,422,423,440$}

Cores 422 and 423 were taken from a low lying pasture on the northwest side of the upper portion of Haynes inlet 5.9 $\mathrm{km}(3.6 \mathrm{mi})$ due east of the ocean. Cores 416 and 440 were taken from the east side of the upper portion of Haynes inlet south of Palouse Slough $7.5 \mathrm{~km}(4.6 \mathrm{mi})$ due east of the 
ocean. They were taken from pasture land protected by tide gates (figure 12).

Core 422 - This $400 \mathrm{~cm}$ long core consists of peaty mud from the surface down to $60 \mathrm{~cm}$. It has a gradual lower contact and grades into slightly peaty mud which extends to $86 \mathrm{~cm}$. At $86 \mathrm{~cm}$ there is peaty mud with sharp upper and sharp lower contacts. It extends down to $97 \mathrm{~cm}$. From $97 \mathrm{~cm}$ to 114 $\mathrm{cm}$ slightly peaty mud with a gradual lower contact is seen. The peaty mud grades into mud which continues down core to $165 \mathrm{~cm}$ where it grades into a slightly peaty mud. The slightly peaty mud has a gradual lower contact at $175 \mathrm{~cm}$. From $175 \mathrm{~cm}$ to the end of the core at $400 \mathrm{~cm}$ there is mud. Three portions of the mud contain small amounts of sand. These sands represent basal channel flood deposits.

Core 423- This core was taken $0.5 \mathrm{~km}(0.31 \mathrm{mi})$ northeast of core 422. It is $175 \mathrm{~cm}$ long. The top of the core from the surface down to $63 \mathrm{~cm}$ is peaty mud with a gradual lower contact at $63 \mathrm{~cm}$. It grades into slightly peaty mud which extends down core to $84 \mathrm{~cm}$. At $84 \mathrm{~cm}$ there is peaty mud which extends to $103 \mathrm{~cm}$. The peaty mud has a sharp upper contact and a gradual lower contact. From $103 \mathrm{~cm}$ to $167 \mathrm{~cm}$ there is slightly peaty mud with a gradual lower contact. It grades into mud which continues to the bottom of the core at $175 \mathrm{~cm}$. This core records one burial event at a depth of 84 $\mathrm{cm}$. 
Core 416- This core is $200 \mathrm{~cm}$ long and contains peaty mud from the surface to a depth of $50 \mathrm{~cm}$. It has a gradual lower contact where it grades into slightly peaty mud which extends down to $70 \mathrm{~cm}$. At $70 \mathrm{~cm}$ there is muddy peat with a sharp upper contact and a gradual lower contact. At $90 \mathrm{~cm}$ it grades into slightly peaty mud which extends down to $184 \mathrm{~cm}$ where there is a gradual lower contact. From $184 \mathrm{~cm}$ to the end of the core at $200 \mathrm{~cm}$ there is mud.

Core 440 - This core was taken $0.3 \mathrm{~km}(0.18 \mathrm{mi})$ southwest of core 416 near an unnamed stream. It is $300 \mathrm{~cm}$ long. From the surface to a depth of $100 \mathrm{~cm}$ the core contains peaty mud. The nature of the lower contact (sharp or gradational) was not logged. From $100 \mathrm{~cm}$ to $200 \mathrm{~cm}$ there is slightly peaty muddy sand. This lower contact was also not logged with respect to being sharp or gradational. At $200 \mathrm{~cm}$ there is slightly peaty sandy mud which extends to the end of the core at $300 \mathrm{~cm}$.

Cores 422 and 423 were taken on the opposite side of Haynes Inlet (approximately $2 \mathrm{~km}$ or $1.2 \mathrm{mi}$ ) from core 416 . All three of these cores contain evidence of a buried peat at roughly the same depth (approximately $73-84 \mathrm{~cm}$ ).

\section{Palouse slough Cores - 427, 428,437,417,426,438,}

\section{$439,448,425, \quad 424$}

All of these cores were taken from tidal gate protected 
marshy areas near small tributary stream of Palouse Creek (cores are listed west to east proceeding upstream; (figure 12)). Local residents report that the pasture lands of the Palouse Slough area were regularly flooded by high tides prior to the installation of the tidal gates.

Core 427 - This core was taken $7 \mathrm{~km}(4.3 \mathrm{mi})$ due east of the ocean at the point where Palouse Creek bends toward the east. It was taken on the south side of Palouse creek. It is $360 \mathrm{~cm}$ long. The top $50 \mathrm{~cm}$ of the core was not recovered. From $50 \mathrm{~cm}$ to $103 \mathrm{~cm}$ there is slightly peaty mud which grades into mud. The mud continues to a depth of $110 \mathrm{~cm}$ where it grades into a slightly muddy sand. From $110 \mathrm{~cm}$ to $125 \mathrm{~cm}$ there is slightly muddy sand which grades into slightly peaty sandy mud. At $138 \mathrm{~cm}$ the slightly peaty sandy mud grades into slightly muddy sand which continues to $145 \mathrm{~cm}$ where it grades into peaty mud to a depth of $158 \mathrm{~cm}$. It has a sharp lower contact. Mud and sand are seen from $158 \mathrm{~cm}$ down core to $200 \mathrm{~cm}$. From $200 \mathrm{~cm}$ to $228 \mathrm{~cm}$ there is slightly peaty mud. At $228 \mathrm{~cm}$ the core contains sand which extends to $320 \mathrm{~cm}$. From $320 \mathrm{~cm}$ to $333 \mathrm{~cm}$ there is slightly sandy mud. The remainder of the core, from $333 \mathrm{~cm}$ to $360 \mathrm{~cm}$, consists of sand. This core's stratigraphic development can be best explained as the result of past migrations of Palouse Creek in the last 3,000 years. 
Core 428- This core was taken $7.2 \mathrm{~km}$ (4.4 mi) due east of the ocean on the north of Palouse Creek in a marshy area near the inlet of a small stream, This $400 \mathrm{~cm}$ long core contains muddy peat with a gradual lower contact from the surface down to $10 \mathrm{~cm}$. It grades into peaty mud which extends down to $68 \mathrm{~cm}$. It also has a gradual lower contact and grades into slightly peaty mud to a depth of $77 \mathrm{~cm}$. From $77 \mathrm{~cm}$ to $115 \mathrm{~cm}$ there is peaty mud which has a sharp upper contact and a gradual lower contact. It grades into slightly peaty mud which continues down to $157 \mathrm{~cm}$. At $157 \mathrm{~cm}$ there is muddy peat with a sharp upper contact. It has a gradual lower contact at $171 \mathrm{~cm}$ where it grades into a peaty mud which has a gradual lower contact at $175 \mathrm{~cm}$. This peaty mud grades into slightly peaty mud which extends down core to 196 $\mathrm{cm}$. At $196 \mathrm{~cm}$ peaty mud with a sharp upper contact and gradual lower contact is evident. The peaty mud grades into slightly peaty mud at $205 \mathrm{~cm}$. The slightly peaty mud continues to $225 \mathrm{~cm}$ where it grades into mud with a gradual lower contact at $372 \mathrm{~cm}$. The mud grades into sand which extends to the end of the core at $400 \mathrm{~cm}$. This core records three episodically buried peats.

Core 437- This core was taken within $3 \mathrm{~m}$ of a small tributary stream in the Palouse slough and $10 \mathrm{~m}$ southeast of core 428. This core was also taken at the outside of a wide bend of Palouse creek It is $180 \mathrm{~cm}$ long and consists of muddy peat from the surface to a depth $10 \mathrm{~cm}$ where it grades 
into slightly peaty mud down to $49 \mathrm{~cm}$. From $49 \mathrm{~cm}$ to $140 \mathrm{~cm}$ there is mud with small amounts of detrital material

throughout. At $140 \mathrm{~cm}$ the mud grades into sand which extends to the end of the core at $180 \mathrm{~cm}$. The stratigraphic characteristics seen in this core are likely the result of lateral erosion as the stream cut the bank and subsequent deposition of continuous and uniformly graded sediments as the stream migrated away from the area.

Core 417- This core was taken from a low lying pasture on the south side of Palouse creek $7.8 \mathrm{~km}(4.8 \mathrm{mi})$ due east of the ocean. It is $200 \mathrm{~cm}$ long. From the surface to a depth of $40 \mathrm{~cm}$ there is peaty mud with a gradual lower contact. It grades into slightly peaty mud down to $72 \mathrm{~cm}$. At $72 \mathrm{~cm}$ there is peaty mud with a sharp upper contact and a gradual lower contact. From $88 \mathrm{~cm}$ to $110 \mathrm{mud}$ is evident. The mud tops a detrital layer which has a sharp upper contact and extends down to $114 \mathrm{~cm}$. At $114 \mathrm{~cm}$ there is sand with a sharp upper contact. The sand extends to $116 \mathrm{~cm}$. From $116 \mathrm{~cm}$ to $180 \mathrm{~cm}$ there is muddy peat with a sharp upper contact and a gradual lower contact. The muddy peat grades into slightly peaty mud which continues to the end of the core at $200 \mathrm{~cm}$. This core possibly shows two episodically buried peats at depths of $72 \mathrm{~cm}$ and $116 \mathrm{~cm}$.

Core 426- This core was taken from a pasture $8.3 \mathrm{~km} 15.1$ mi) due east of the ocean on the north side of Palouse creek (north of the Palouse Creek Road). The top of this $500 \mathrm{~cm}$ 
long core contains mudidy peat from the surface down to $45 \mathrm{~cm}$ where there is a gradual contact. The muddy peat grades down into slightly peaty mud to a depth of $91 \mathrm{~cm}$. At $91 \mathrm{~cm}$ there is muddy peat with a sharp upper contact and a gradual lower contact. From $103 \mathrm{~cm}$ to $160 \mathrm{~cm}$ there is peaty mud with a gradual lower contact. The peaty mud grades into slightly peaty mud to a depth of $182 \mathrm{~cm}$. At $182 \mathrm{~cm}$ there is peaty mud with a sharp upper contact and a gradual lower contact. At $200 \mathrm{~cm}$ the peaty mud grades into slightly peaty mud which has a gradual lower contact at $232 \mathrm{~cm}$. The slightly peaty mud grades into slightly sandy mud which extends to $267 \mathrm{~cm}$. Slightly peaty mud with a sharp upper contact and gradual lower contact is evident from $267 \mathrm{~cm}$ to $400 \mathrm{~cm}$ where it grades into mud which extends to $435 \mathrm{~cm}$. At $435 \mathrm{~cm}$ the mud grades into slightly sandy mud which continues to the bottom of the core at $500 \mathrm{~cm}$. This core shows three probable buried peaty horizons.

Core 438 (figure 14)- This core was taken just south of core 426 and north of Palouse creek Road. It is $140 \mathrm{~cm}$ in length. The top $10 \mathrm{~cm}$ of the core contains muddy peat with a gradual lower contact. The muddy peat grades into peaty mud which extends to $78 \mathrm{~cm}$ where it grades into muddy peat. At $95 \mathrm{~cm}$ the muddy peat grades into mud which contains small amounts of sand and detrital material. The mud continues to the end of the core at $140 \mathrm{~cm}$. 
Core 448 (figure 14) - This core was taken at the north side of Palouse Creek where a small tributary flows into the creek. The core is $300 \mathrm{~cm}$ long. From the surface to a depth of $35 \mathrm{~cm}$ the core contains slightly muddy peat with a gradual lower contact. It grades into muddy peat which extends down core to $57 \mathrm{~cm}$. The muddy peat grades into slightly peaty mud. At $70 \mathrm{~cm}$ there is muddy peat with a sharp upper contact. This muddy peat has a date of $1,800 \pm 60$ RCYBP. From $85 \mathrm{~cm}$ the muddy peat grades downward into slightly peaty mud to a depth of $92 \mathrm{~cm}$ where it grades into peaty mud. At $120 \mathrm{~cm}$ the peaty mud grades into mud which extends down core to $124 \mathrm{~cm}$. The mud grades down into very slightly muddy peat that extends to $160 \mathrm{~cm}$. Very slightly peaty mud is evident from $160 \mathrm{~cm}$ to $170 \mathrm{~cm}$ where it grades down into peaty mud. This peaty mud grades into muddy peat at $200 \mathrm{~cm}$. This muddy peat dates at $2,830 \pm 100$ RCYBP. The muddy peat extends to $228 \mathrm{~cm}$ where it grades into peaty mud. The peaty mud extends to $245 \mathrm{~cm}$ and then grades into muddy peat to a depth of 266 $\mathrm{cm}$. At $266 \mathrm{~cm}$ the muddy peat grades into slightly peaty mud. The slightly peaty mud continues to the end of the core at $300 \mathrm{~cm}$. This core contains evidence of possibly four abrupt subsidence events in the last 2,800 years based on the peatmud separations observed. The buried peats occur at subsurface depths of $70 \mathrm{~cm}, 92 \mathrm{~cm}, 125 \mathrm{~cm}$, and $170 \mathrm{~cm}$. 
Core 439- This core was taken $1 \mathrm{~m}$ from core 448 . Its stratigraphy is identical to core 448 with the addition of $100 \mathrm{~cm}$ of slightly peaty mud at the bottom of the core.

Core 425- This core was taken from a pasture south of Palouse Creek Road and north of Palouse Creek. It is $300 \mathrm{~cm}$ long. The top portion of the core consists of peaty mud from the surface to a depth of $60 \mathrm{~cm}$. The peaty mud grades into slightly peaty mud with a gradual lower contact at $137 \mathrm{~cm}$. At this point the slightly peaty mud grades into slightly sandy mud to a depth of $180 \mathrm{~cm}$. Peaty mud with a sharp upper contact and a gradual lower contact is evident from $180 \mathrm{~cm}$ to $220 \mathrm{~cm}$ where it grades down into mud. At $250 \mathrm{~cm}$ the mud grades into slightly sandy mud which extends to the end of the core at $300 \mathrm{~cm}$. This core shows possibly one buried peat with a sharp upper contact.

Core 424- This core was taken $11 \mathrm{~km}(6.7 \mathrm{mi})$ due east of the ocean. It was taken from a pasture which has been subjected to the migration of Palouse creek. It is $250 \mathrm{~cm}$ long. From the surface to a depth of $125 \mathrm{~cm}$ the core contains muddy sand. At $125 \mathrm{~cm}$ there is peaty mud with sharp upper and lower contacts. The peaty, mud extends down to 185 $\mathrm{cm}$. From $185 \mathrm{~cm}$ to $200 \mathrm{~cm}$ slightly peaty mud is seen. The slightly peaty mud grades into mud. This mud extends to a depth of $222 \mathrm{~cm}$. At $222 \mathrm{~cm}$ there is peaty mud with a sharp upper contact. The peaty mud grades into mud which continues to the end of the core at $250 \mathrm{~cm}$. This core may contain one 
buried peat. However, the core site is in a narrow upper valley of Palouse Creek where the stream migrates back and forth, so long-term records of subsidence are limited. Thus, it is more likely that this core's stratigraphy is a result of stream cut and fill.

\section{Rentuck Slough Cores $-450,432,433,449,473$}

Kentuck Slough flows into the east side of coos Bay aGlasgow Point. All the cores were taken from pastures in a wide flat valley protected by a tide gate. Surveyed core site elevations (Appendix B) indicate that these sites would be flooded by high tides if it were not for the presence of the tidal gate.

Core 450- This core was taken $9.2 \mathrm{~km}(5.6 \mathrm{mi})$ due east of the ocean on the south side of Kentuck slough near the inlet. It is $300 \mathrm{~cm}$ long. From the surface to a depth of $212 \mathrm{~cm}$ the core contains peaty mud. At $212 \mathrm{~cm}$ this peaty mud grades down into sand which extends to the end of the core at $300 \mathrm{~cm}$.

Core 432- This core was taken at the point where Mettman Creek enters Kentuck slough $10.2 \mathrm{~km}(6.2 \mathrm{mi})$ due east of the ocean. The core site is located $5 \mathrm{~m}$ north of the Kentuck slough Road. All contacts in the core are gradual. This 400 $\mathrm{cm}$ long core consists of peat from the surface to a depth of 
$18 \mathrm{~cm}$. From $18 \mathrm{~cm}$ to $83 \mathrm{~cm}$ there is mud which grades down into peaty mud extending to $95 \mathrm{~cm}$. At $95 \mathrm{~cm}$ the peaty mud grades down into mud. This mud continues down core to $150 \mathrm{~cm}$ where it grades into muddy peat. At $188 \mathrm{~cm}$ it grades into mud which extends to the end of the core at $400 \mathrm{~cm}$. The core contains evidence of two abruptly buried peats at depths of $83 \mathrm{~cm}$ and $150 \mathrm{~cm}$.

Core 449 (figure 14)- This core was taken $0.25 \mathrm{~km} \quad(0.15$ mi) north of core 432 in the midile of the pasture next to Mettman Creek. The top portion of this $265 \mathrm{~cm}$ from the surface to $50 \mathrm{~cm}$ was not recovered. At $50 \mathrm{~cm}$ there is slightly peaty mud which extends down to $58 \mathrm{~cm}$. From $58 \mathrm{~cm}$ to $65 \mathrm{~cm}$ there is muddy peat with a sharp upper contact and gradual lower contact. This muddy peat dates at $1000 \pm 50$ RCYBP. It grades into peaty mud. This peaty mud extends to $70 \mathrm{~cm}$ where it grades into slightly peaty mud. At a depth of $88 \mathrm{~cm}$ there is muddy peat with a sharp upper contact and a gradual lower contact at $110 \mathrm{~cm}$. This muddy peat dates at $1390 \pm 60$ RCYBP. From $110 \mathrm{~cm}$ the muddy peat grades into peaty mud to a depth of $118 \mathrm{~cm}$ where the peaty mud grades into slightly peaty mud which extends down to $129 \mathrm{~cm}$. Peaty mud with a sharp upper and gradual lower contact is evident from $129 \mathrm{~cm}$ to $147 \mathrm{~cm}$ and has a date of 1,780 \pm 60 RCYBP. The peaty mud grades into mud containing small amounts of detrital material. The mud continues to the bottom of the 
core at $265 \mathrm{~cm}$. The stratigraphy of this core indicates three buried peats at depths of $65 \mathrm{~cm}, 88 \mathrm{~cm}$, and $129 \mathrm{~cm}$. Core 433- This core was taken $0.33 \mathrm{~km}(0.20 \mathrm{mi})$ north of 432 on the west side of the pasture next to Mettman Creek. It is $365 \mathrm{~cm}$ long. The top of the core from the surface to a depth of $18 \mathrm{~cm}$ is peat. The portion of the core from $18 \mathrm{~cm}$ to $50 \mathrm{~cm}$ was not recovered. From $50 \mathrm{~cm}$ to $137 \mathrm{~cm}$ there is peaty mud with a gradual lower contact. The peaty mud grades down into peat which extends to a depth of $157 \mathrm{~cm}$. It grades into peaty mud from $157 \mathrm{~cm}$ to $232 \mathrm{~cm}$. At $232 \mathrm{~cm}$ the peaty mud grades into mud to a depth of $326 \mathrm{~cm}$. From $326 \mathrm{~cm}$ to 355 $\mathrm{cm}$ the mud grades into peaty mud. A basal sand with a sharp upper contact extends from $355 \mathrm{~cm}$ to the end of the core at $365 \mathrm{~cm}$. This core shows one, possibly two buried peats at depths of $137 \mathrm{~cm}$ and $326 \mathrm{~cm}$.

Core 473- This core was taken $11.3 \mathrm{~km}(6.9 \mathrm{mi})$ due east of the ocean on the south side of a meander bend of Kentuck Creek. The top of this $400 \mathrm{~cm}$ long core consists of slightly peaty mud from the surface down to $118 \mathrm{~cm}$ where there is a gradual lower contact. It grades down into slightly sandy mud which extends to a depth of $267 \mathrm{~cm}$. At $267 \mathrm{~cm}$ the slightly sandy mud grades into slightly peaty mud down to 292 $\mathrm{cm}$. From $292 \mathrm{~cm}$ to $305 \mathrm{~cm}$ the peaty mud grades into muddy sand which contains small amounts of detrital material. The lower contact is probably gradual. From 305 to 320 there is slightly peaty mud which has a gradual lower contact. At 320 
$\mathrm{cm}$ it grades into muddy sand which contains detrital material throughout and extends to the bottom of the core at $400 \mathrm{~cm}$. The location of the core site on a meandering section of Kentuck Creek exposes it to stream cut and fill.

In the northern Coos Bay area, progressing west to east the cores change in nature from predominately continuous peaty cores to episodically buried peat cores within an area along the eastern shoreline of coos Bay. The maximum number of buried peats is four. The number of buried peats and the depth of burial increases eastward. The incidence of sharp upper contacts increase to the east suggesting sudden rather than gradual subsidence there.

\section{Southern Area}

The southern area of Coos Bay extends from UTM4790000 mN to UTM4809500 $\mathrm{mN}$ and includes sunset Bay, South Slough, Coos Bay (Bar View and Empire area), Pony Slough, Coalbank Slough, Shinglehouse Slough, White Point, Catching Slough, Vogel Creek, Coos River Smith Ranch, Millicoma River, Daniels Creek, and South Fork coos River. The area extends inland $25 \mathrm{~km}(15.3 \mathrm{mi})$ due east from the ocean. Cores were taken from tidal and freshwater marshes, natural meadows, and cultivated pastures. 


\section{Sunset Bay Cores - 401, 462}

These cores were taken from a low lying wooded area in Sunset Bay state Park just off of Big Creek $0.2 \mathrm{~km}(0.12 \mathrm{mi})$ southeast of Sunset Bay. These core sites are presently above the reach of high tides. Nevertheless, an abundance of peaty sections downcore suggests the river valley has backfilled in response to rising sea level in late Holocene time. The episodic development of wetlands (peat) might reflect local changes in relative sea level in sunset Bay. However, this small embayment is also directly exposed to storm surges from the open ocean. The response of wetlands to open ocean storm surges, river floods and/or tectonic vertical displacements in embayments such as sunset Bay have not previously been investigated.

Core 401- This $400 \mathrm{~cm}$ long core consists of peat from the surface down to $20 \mathrm{~cm}$. At $20 \mathrm{~cm}$ it grades down into sandy mud which extends to $60 \mathrm{~cm}$ where there is a gradual lower contact. From $60 \mathrm{~cm}$ to $83 \mathrm{~cm}$ there is sandy muddy peat which has a gradual lower contact. At $83 \mathrm{~cm}$ the sandy muddy peat grades down into sandy peaty mud to a depth of $150 \mathrm{~cm}$. At this point the sandy peaty mud grades into sandy peat which has a sharp lower contact at $163 \mathrm{~cm}$. From $163 \mathrm{~cm}$ to $215 \mathrm{~cm}$ there is mud which contains small amounts of detrital 
material and has a gradual lower contact. It grades down into peaty mud which has a gradual lower contact at $230 \mathrm{~cm}$. From $230 \mathrm{~cm}$ the peaty mud grades down into muddy peat which contains small amounts of sand and detrital material. At 258 $\mathrm{cm}$ there is a gradual lower contact. From $258 \mathrm{~cm}$ to the end of the core at $400 \mathrm{~cm}$ the muddy peat grades into peat which contains detrital material throughout.

Core 462 (figure 15)- This core is $585 \mathrm{~cm}$ long. From the surface to a depth of $23 \mathrm{~cm}$ there is peat with a gradual lower contact. The peat grades into sandy mud which extends down to $75 \mathrm{~cm}$. At $75 \mathrm{~cm}$ there is slightly sandy muddy peat which has a sharp upper contact and a gradual lower contact at $95 \mathrm{~cm}$ where it grades into slightly peaty mud below. The slightly peaty mud continues to a depth of $141 \mathrm{~cm}$. At this point it grades into muddy peat which has a sharp lower contact at $150 \mathrm{~cm}$. From $150 \mathrm{~cm}$ to $157 \mathrm{~cm}$ there is slightly peaty mud. Peat is evident from $157 \mathrm{~cm}$ to $169 \mathrm{~cm}$. The peat has sharp upper and lower contacts. From $169 \mathrm{~cm}$ to $195 \mathrm{~cm}$ there is mud which has a gradual lower contact. The mud grades into muddy peat which extends to $200 \mathrm{~cm}$. From $200 \mathrm{~cm}$ to 225 the muddy peat grades into mud. At $225 \mathrm{~cm}$ peat with a sharp upper contact and sharp lower contact at $259 \mathrm{~cm}$ is found. Mud is seen from $259 \mathrm{~cm}$ to $263 \mathrm{~cm}$. At $263 \mathrm{~cm}$ there is peat with a sharp upper contact and a gradual lower contact. At $285 \mathrm{~cm}$ the peat grades into slightly peaty mud 
Radiocarbon dates (C-14 AGE YRS B.P. $\pm 1 \sigma$ )

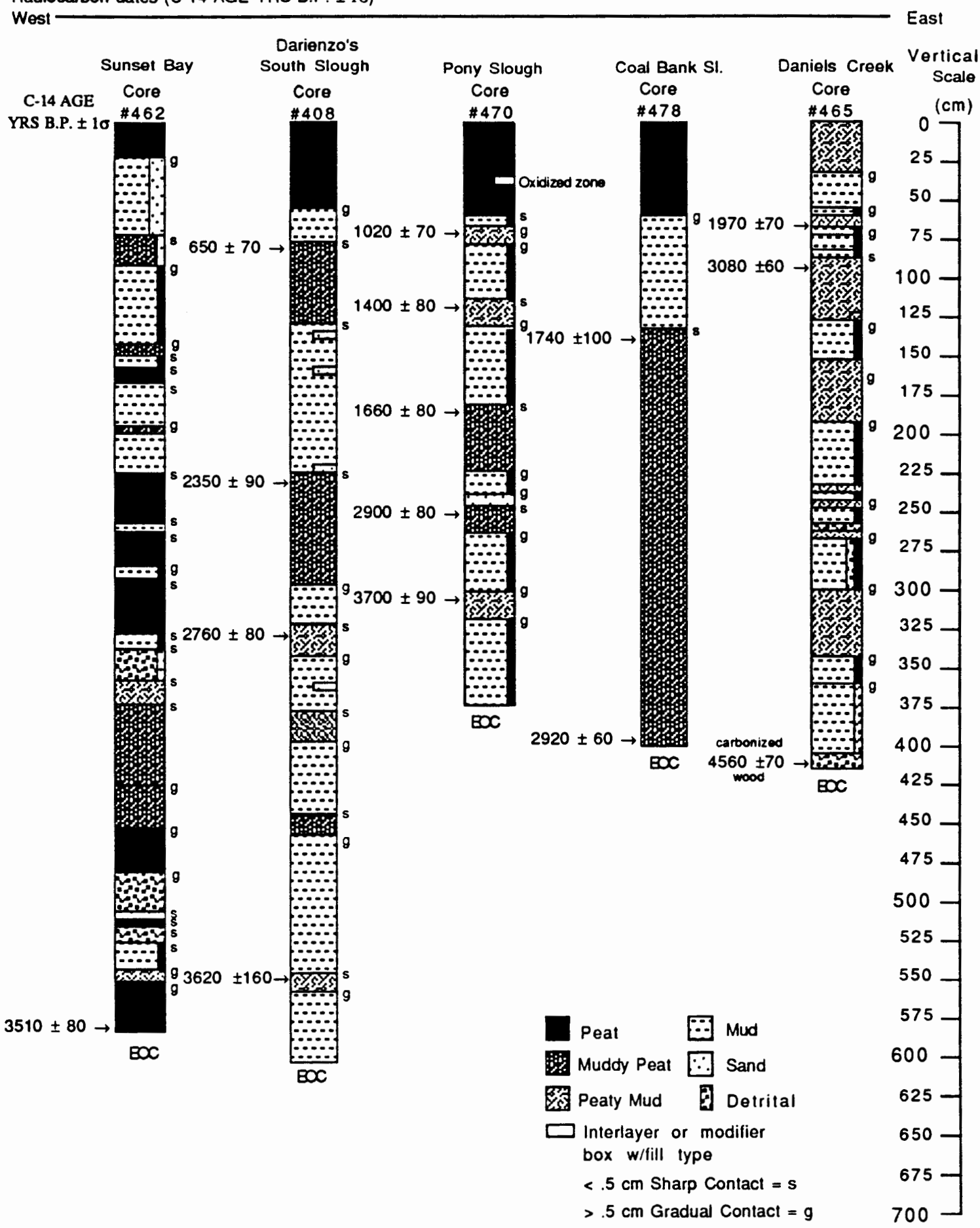

Figure 15. Coos Bay (southern area) radiocarbon dated cores. Elevation corrections for the tops of cores taken in this southern Coos bay area were typically between $+0.53 \mathrm{~m}$ and $+2.65 \mathrm{~m}$ above mean sea level ( high marsh, upper intertidal). See appendix $B$ for elevation range and Coos Bay core map for location of southern core sites. 
which extends to $290 \mathrm{~cm}$. Peat with sharp upper and sharp lower contacts is evident from $290 \mathrm{~cm}$ to $328 \mathrm{~cm}$. At $328 \mathrm{~cm}$ there is slightly peaty mud which continues to a depth of 339 $\mathrm{cm}$. From $339 \mathrm{~cm}$ to $357 \mathrm{~cm}$ there is slightly sandy detrital material which has sharp upper and sharp lower contacts. Peaty mud is seen from $357 \mathrm{~cm}$ to $371 \mathrm{~cm}$. At this point there is muddy peat which extends to $450 \mathrm{~cm}$. This muddy peat has sharp upper and gradual lower contacts. At $450 \mathrm{~cm}$ it grades down into peat which has a gradual lower contact at $480 \mathrm{~cm}$. From $480 \mathrm{~cm}$ the peat grades into detrital material which extends to a depth of $505 \mathrm{~cm}$. At $505 \mathrm{~cm}$ there is a thin layer of sand which has a sharp upper contact. At $508 \mathrm{~cm}$ there is peat with a sharp upper contact and a sharp lower contact. From $515 \mathrm{~cm}$ to $525 \mathrm{~cm}$ there is a layer of detrital material. At $525 \mathrm{~cm}$ there is slightly peaty mud which extends to a depth $545 \mathrm{~cm}$ and has a sharp upper contact and a gradual lower contact. At $545 \mathrm{~cm}$ it grades into peaty mud which continues down to $550 \mathrm{~cm}$. The peaty mud grades into peat which continues to the end of the core at $585 \mathrm{~cm}$. The basal date is $3510 \pm 80$ RCYBP. This core contains at least nine buried peats and/or detrital organic zones.

Cores 401 and 462 were taken from an area at Sunset Bay with a known fault structure first inferred and mapped by Allen and Baldwin in 1944 (Allen and Baldwin, 1944), later mapped by others. This complex area is exposed to the bay but also located at the mouth of a narrow creek valley. Debris 
flows down the steep sided canyon and storm surge detrital material washed in from the ocean may have affected the stratigraphy. Even so, these cores show multiple peaty to muddy transitions suggesting episodically buried sequences.

\section{South Slough Cores $-480,479,409,408$}

The South Slough is a tidal marsh $4.2 \mathrm{~km}(2.6 \mathrm{mi})$ southeast of the south jetty of Coos Bay (figure 12).

Core 480- This core was taken on the west shore of South Slough $0.8 \mathrm{~km}(0.49 \mathrm{mi})$ south of Valino Island. It is $275 \mathrm{~cm}$ long and contains peat from the surface down to $35 \mathrm{~cm}$ where there is a gradual lower contact. At $35 \mathrm{~cm}$ the peat grades down to mud which extends down to $190 \mathrm{~cm}$. At $190 \mathrm{~cm}$ the mud grades into a basal sand which continues to the bottom of the core at $275 \mathrm{~cm}$.

Core 479 - This $200 \mathrm{~cm}$ core was taken $0.3 \mathrm{~km}(0.18 \mathrm{mi})$ north of core 480 and consists of peat from the surface to a depth of $31 \mathrm{~cm}$ where there is a gradual lower contact. The peat grades into mud which extends to the end of the core at $200 \mathrm{~cm}$.

Core 409- This core was taken by Peterson and Darienzo (1989) on the east side of South slough at the point where Day Creek enters the slough. This core is $500 \mathrm{~cm}$ long. The top portion of the core from the surface to a depth of $57 \mathrm{~cm}$ 
there is peat with a gradual lower contact. The peat grades into mud which extends to $78 \mathrm{~cm}$. At $78 \mathrm{~cm}$ there is muddy peat with a sharp upper contact and a gradual lower contact. From $87 \mathrm{~cm}$ the muddy peat grades into mud to a depth of 113 $\mathrm{cm}$. At $113 \mathrm{~cm}$ there is muddy peat with a sharp upper contact and a gradual lower contact. The muddy peat grades into mud at $133 \mathrm{~cm}$. The mud extends down to $160 \mathrm{~cm}$. At the bottom of this mud there is a distinct thin sand lens. At $160 \mathrm{~cm}$ there is peaty mud with sharp upper and sharp lower contacts. It extends to $175 \mathrm{~cm}$. Mud is evident from $175 \mathrm{~cm}$ to $205 \mathrm{~cm}$. At $205 \mathrm{~cm}$ there is muddy peat with a sharp upper contact and a gradual lower contact. This muddy peat grades into mud at 217 $\mathrm{cm}$. The mud extends down to $355 \mathrm{~cm}$. At $355 \mathrm{~cm}$ there is peaty mud with a sharp upper contact and a gradual lower contact evident at $364 \mathrm{~cm}$. The peaty mud grades into mud which continues to the end of the core at $500 \mathrm{~cm}$. This peaty mud contains three sand lenses. The core shows evidence of five episodically buried peats at depths of $78 \mathrm{~cm}, 113 \mathrm{~cm}$, $160 \mathrm{~cm}, 205 \mathrm{~cm}$ and $355 \mathrm{~cm}$.

Core 408 (figure 15)- This core was taken from a tidal marsh $20 \mathrm{~km}(12.2 \mathrm{mi})$ east of core 409 . The data for this core is also used with the permission of Peterson and Darienzo (GSA Abstract, 1989). This $600 \mathrm{~cm}$ long core contains peat from the surface to a depth of $55 \mathrm{~cm}$ where it grades into mud. At $77 \mathrm{~cm}$ there is muddy peat with a sharp upper contact and a gradual lower contact. The top $10 \mathrm{~cm}$ of 
this muddy peat date at $650 \pm 70$ RCYBP. From $132 \mathrm{~cm}$ the muddy peat grades into mud which extends to $225 \mathrm{~cm}$. The mud contains three sand lenses. At $225 \mathrm{~cm}$ there is muddy peat which has a sharp upper contact and a gradual lower contact at $295 \mathrm{~cm}$. This muddy peat dates at 2,350 \pm 90 RCYBP. At $295 \mathrm{~cm}$ it grades into mud. The mud continues down to a depth of $325 \mathrm{~cm}$. At $325 \mathrm{~cm}$ there is peaty mud dated at $2,760 \pm 80$ RCYBP. It has a sharp upper contact and a gradual lower contact. The peaty mud grades into mud at $345 \mathrm{~cm}$. This mud extends down to $382 \mathrm{~cm}$ and contains a sand lens. From $382 \mathrm{~cm}$ there is peaty mud with a sharp upper contact and gradual lower contact at $400 \mathrm{~cm}$. At this point the peaty mud grades into mud to a depth of $445 \mathrm{~cm}$. From $445 \mathrm{~cm}$ to there is muddy peat with a sharp upper contact and a gradual lower contact. At $460 \mathrm{~cm}$ it grades into mud. Peaty mud with a sharp upper contact and a gradual lower contact is evident from $547 \mathrm{~cm}$ to 560. This peaty mud is dated at $3,620 \pm 160$ RCYBP. It grades into mud which continues to the end of the core at 600 $\mathrm{cm}$. This core contains evidence of six episodically buried peats. Other cores taken by Peterson and Darienzo on Talbot Creek at the southeast end of South Slough also contain evidence of multiple buried peats (GSA Abstract, 1989).

Cores 480 and 479, taken from the west side of South Slough, are non-diagnostic cores which contain no evidence of marsh burial events. Cores 408 and 409, taken from the east side of South Slough, contain evidence of five to six buried 
wetlands. South slough is one of several synclinal structures in the coos Bay area. The differences in stratigraphy observed when comparing core 480 and 479 with cores 408, 409, and cores from Talbot Creek (Peterson and Darienzo, abstract, 1989) suggests an asymmetry in the South Slough synclinal basin, with respect to episodic submergence.

Coos Bay - Bar View Area Cores - 402, 403, 404, 434, $\underline{435, \quad 436}$

These cores were taken from an isolated fresh water marsh area $3 \mathrm{~km}(1.8 \mathrm{mi})$ due east of the ocean just east of Bar View Wayside. This marsh has been significantly altered by diking and dredge spoil dumping. The youngest horizons in the core tops might be disturbed or even the result of artificial disturbance in this locality.

Core $402-$ This core is $480 \mathrm{~cm}$ long and contains peat from the surface to a depth of $208 \mathrm{~cm}$. This peat contains a diffused sand lens at $150 \mathrm{~cm}$. From $208 \mathrm{~cm}$ to $210 \mathrm{~cm}$ there is a thin sand layer with sharp upper and lower contacts. At $210 \mathrm{~cm}$ there is peat which extends to a depth of $260 \mathrm{~cm}$ where there is a gradual lower contact. The peat grades into sand. The sand continues down to $290 \mathrm{~cm}$ where it grades into detrital material with a gradual lower contact. This detrital material grades down into a varying mixture of sand 
and mud. At $425 \mathrm{~cm}$ the sand and mud mix grades into peat which extends to $450 \mathrm{~cm}$ where it has a sharp lower contact. From $450 \mathrm{~cm}$ to the bottom of the core at $480 \mathrm{~cm}$ muddy sand is seen. The sharp thin sand layers seen between $125 \mathrm{~cm}$ and 225 $\mathrm{cm}$ are suggestive of tsunami deposited sands.

Core 403-This core is $390 \mathrm{~cm}$ long. From the surface to a depth of $32 \mathrm{~cm}$ there is peat with a gradual lower contact. The peat grades into mud which continues down to $51 \mathrm{~cm}$. From $51 \mathrm{~cm}$ to $131 \mathrm{~cm}$ there is muddy peat which has a sharp upper contact and a gradual lower contact. The muddy peat grades down into mud. At $142 \mathrm{~cm}$ there is a detrital layer which extends down to $145 \mathrm{~cm}$. This layer has sharp upper contact and a gradual lower contact. At $145 \mathrm{~cm}$ it grades down into sand which continues to a depth of $155 \mathrm{~cm}$. From $155 \mathrm{~cm}$ to $315 \mathrm{~cm}$ there is slightly sandy muddy peat with a sharp upper contact and a gradual lower contact. At $315 \mathrm{~cm}$ it grades into sand which extends down core to $370 \mathrm{~cm}$. The remainder of the core consists of muddy peat which has a sharp upper contact. This core shows evidence of three episodically buried peats at depths of $51 \mathrm{~cm}, 155 \mathrm{~cm}$, and $370 \mathrm{~cm}$.

core 404- Muddy peat with a gradual lower contact is seen in the top $20 \mathrm{~cm}$ of this $270 \mathrm{~cm}$ long core. At $20 \mathrm{~cm}$ it grades into mud which extends to a depth of $70 \mathrm{~cm}$. At $70 \mathrm{~cm}$ there is detrital material with a sharp upper contact. It has a gradual lower contact at $75 \mathrm{~cm}$ where it grades into sand to a depth of $92 \mathrm{~cm}$. From $92 \mathrm{~cm}$ to $110 \mathrm{~cm}$ there is 
muddy peat with a sharp upper and a sharp lower contact. At $110 \mathrm{~cm}$ sand containing detrital material is evident to a depth of $125 \mathrm{~cm}$. From $125 \mathrm{~cm}$ to the end of the core at 270 cm there is peat which has a sharp upper contact. Two possible buried peat horizons are evident in this core at depths of $92 \mathrm{~cm}$ and $125 \mathrm{~cm}$.

Core 434- The top five centimeters of this $80 \mathrm{~cm}$ long core consists of peat with a sharp lower contact. From five to $21 \mathrm{~cm}$ there is slightly peaty mud. At $21 \mathrm{~cm}$ the slightly peaty mud grades into detrital material which extends to 30 $\mathrm{cm}$. From $30 \mathrm{~cm}$ to $50 \mathrm{~cm}$ there is a sand lens with a sharp upper and a sharp lower contact. From $50 \mathrm{~cm}$ to the end of the core at $80 \mathrm{~cm}$ there are chunks of wood.

Core 436- The top $10 \mathrm{~cm}$ of this $75 \mathrm{~cm}$ long core is peat with a sharp lower contact. From $10 \mathrm{~cm}$ to $35 \mathrm{~cm}$ there is slightly peaty mud. At $35 \mathrm{~cm}$ detrital material with a sharp upper and sharp lower contact is evident. It extends to 50 $\mathrm{cm}$. At this point there is a thin sand layer. From $55 \mathrm{~cm}$ to $61 \mathrm{~cm}$ there is peat with sharp upper and lower contacts. wood chunks are present from $61 \mathrm{~cm}$ to the end of the core at $75 \mathrm{~cm}$.

Core 435- This core is $150 \mathrm{~cm}$ long. It contains peat from the surface down to $10 \mathrm{~cm}$. The lower contact is sharp. From $10 \mathrm{~cm}$ to $32 \mathrm{~cm}$ slightly peaty mud is seen. At $32 \mathrm{~cm}$ there is detrital material which extends to $40 \mathrm{~cm}$ and has sharp upper and lower contacts. From $40 \mathrm{~cm}$ to $50 \mathrm{~cm}$ there is 
a sand layer. This sand tops a layer of peat which extends to the end of the core at $150 \mathrm{~cm}$. Contained within this peat are lenses of sand and of detrital material.

The cores from the Bar View area warrant further study. There is some evidence that the area has been modified by human activity which may affect the diagnostic value of the uppermost portions of the core.

\section{Coos Bay - Empire Area Core - 418}

This core was taken from a tidal bank on Coos Bay $100 \mathrm{~m}$ south of navigation marker Midway \#3, just south of Empire. This area is $2.8 \mathrm{~km}(1.7 \mathrm{mi})$ due east of the ocean. There is no substantial marsh preservation along this stretch of bay shoreline.

Core 418- This $200 \mathrm{~cm}$ long core contains peat from the surface down to $127 \mathrm{~cm}$. At $127 \mathrm{~cm}$ there is mud with a sharp upper contact. The mud extends to the end of the core at 200 $\mathrm{cm}$. This is a continuous peaty core for the first $127 \mathrm{~cm}$ of depth.

Pony Slough Cores $-471,472,413,414,455,419,470$, $420,421,451,452,453,454$

The Pony Slough core area is $7 \mathrm{~km}(4.3 \mathrm{mi})$ due east of 
the ocean and extends from the south end of the municipal airport at North Bend south to Thompson Road. Cores 471 , 472, 413, 414, and 455 were taken from a tidal marsh on the east side of Pony Creek, north of Virginia Ave. in North Bend.

Core 471 - This core is $380 \mathrm{~cm}$ in length. The top $35 \mathrm{~cm}$ of the core was not recovered. From $35 \mathrm{~cm}$ to $110 \mathrm{~cm}$ there is muddy peat with a gradual lower contact. It grades into peaty mud which extends down to $119 \mathrm{~cm}$. At $119 \mathrm{~cm}$ the peaty mud grades into muddy sand which continues down to $138 \mathrm{~cm}$. At $138 \mathrm{~cm}$ there is slightly peaty mud with a sharp upper contact and a gradual lower contact at $150 \mathrm{~cm}$. This slightly peaty mud grades into peaty mud which also has a gradual lower contact. At $165 \mathrm{~cm}$ slightly peaty mud is again evident. It extends to a depth of $192 \mathrm{~cm}$ where it grades into mud. This mud continues to a depth of $200 \mathrm{~cm}$ where there is a gradual contact. The mud grades into peat and this peat extends to $213 \mathrm{~cm}$ where there is a gradual lower contact. The peat grades into muddy peat. At $218 \mathrm{~cm}$ there is slightly peaty mud containing a small amount of sand and has a sharp upper contact and a gradual lower contact. From $225 \mathrm{~cm}$ it grades into peaty mud to $230 \mathrm{~cm}$. From $230 \mathrm{~cm}$ to $234 \mathrm{~cm}$ there is a thin sand layer with a sharp upper contact. Muddy peat with a sharp upper contact extends from $234 \mathrm{~cm}$ to $280 \mathrm{~cm}$ where there is a gradual lower contact. The muddy 
peat grades into peaty mud. The peaty mud continues down to $325 \mathrm{~cm}$. It has a gradual lower contact and grades into slightly peaty mud. The slightly peaty mud is seen to a depth of $375 \mathrm{~cm}$ where it grades into sandy mud which continues to the end of the core at $380 \mathrm{~cm}$. There are possibly three episodically buried peats seen in this core at depths of $150 \mathrm{~cm}, 200 \mathrm{~cm}$, and $225 \mathrm{~cm}$.

Core 472- This core was taken $30 \mathrm{~m}$ south of core 471 . It is $400 \mathrm{~cm}$ long. The top of the core from the surface to a depth of $135 \mathrm{~cm}$ varies between muddy peat and peaty mud. From $135 \mathrm{~cm}$ to $175 \mathrm{~cm}$ there is sand with sharp upper and sharp lower contacts interspersed with detrital lenses and mud lenses. At $175 \mathrm{~cm}$ there is peat with a sharp lower contact which extends to $180 \mathrm{~cm}$. Slightly peaty mud is evident from $180 \mathrm{~cm}$ to $215 \mathrm{~cm}$. This interval contains one sand lens at $197 \mathrm{~cm}$ depth. From $215 \mathrm{~cm}$ to $240 \mathrm{~cm}$ there is peat with a sharp upper contact and a gradual lower contact. The peat grades down into muddy peat which extends to a depth of $257 \mathrm{~cm}$. The muddy peat grades into peaty mud. The peaty mud continues down core to $275 \mathrm{~cm}$. At $275 \mathrm{~cm}$ there is peat with sharp upper and lower contacts. Slightly peaty mud is evident from $285 \mathrm{~cm}$ to $350 \mathrm{~cm}$. At $350 \mathrm{~cm}$ there is peat with a sharp upper contact and a gradual lower contact. This peat grades down into peaty mud which extends down to $390 \mathrm{~cm}$. slightly peaty sandy mud with a sharp upper contact makes up the remainder of the core from $390 \mathrm{~cm}$ to $400 \mathrm{~cm}$. This core 
possibly records two buried peats at depths of $175 \mathrm{~cm}$ and 215 $\mathrm{cm}$.

Core 413-This $200 \mathrm{~cm}$ long core was taken $20 \mathrm{~m}$ southeast of core 472. From the surface down to $93 \mathrm{~cm}$ there is peat with a gradual lower contact. The peat grades into muddy peat which extends to a depth of $120 \mathrm{~cm}$ where there is a gradual contact. Peaty mud is seen from $120 \mathrm{~cm}$ to $185 \mathrm{~cm}$ where it grades into mud which continues to the end of the core at $200 \mathrm{~cm}$.

Core 414- This core was taken $20 \mathrm{~m}$ southwest of core 472 and $30 \mathrm{~m}$ west of core 413 . It is $200 \mathrm{~cm}$ long. The top of the core from the surface down to $150 \mathrm{~cm}$ consists of muddy peat which grades into peaty mud. The peaty mud extends to the end of the core at $200 \mathrm{~cm}$.

Cores 413 and 414 are diagnostic cores which record continuous peaty sediments downcore.

Core 455- This core was taken on the south side of Virginia Ave., east of Pony Creek. All contacts in this core are gradual. It is $95 \mathrm{~cm}$ long and contains muddy peat from the surface to a depth of $28 \mathrm{~cm}$. The muddy peat grades into peaty mud which extends down to $43 \mathrm{~cm}$. From $43 \mathrm{~cm}$ to $60 \mathrm{~cm}$ there is slightly sandy peat. At $60 \mathrm{~cm}$ to $70 \mathrm{~cm}$ peaty mud is seen. The peaty mud grades down into slightly peaty mud which continues to the end of the core at $95 \mathrm{~cm}$. The core is a continuous peaty sequence showing no evidence of abrupt burial events in the upper $70 \mathrm{~cm}$ of core depth. 
Core 451- This core was taken on the east side of Pony Creek just north of Thompson Road and just east of woodland Drive. It is $320 \mathrm{~cm}$ long. All of the contacts in this core are gradual. From the surface to a depth of $27 \mathrm{~cm}$ the core contains peaty mud. At $27 \mathrm{~cm}$ it grades into slightly peaty mud which contains small amounts of sand. The slightly peaty mud continues down to $140 \mathrm{~cm}$ where it grades into mud which contains small amounts of sand. The mud extends to the end of the core at $320 \mathrm{~cm}$.

Cores 452, 453, 454 were taken from the same area as core 451. They all contain stratigraphic compositions very similar to core 451 .

Core 421- This core was taken from a tidal marsh on the east side of Pony Creek, $20 \mathrm{~m}$ north of Newmark street. The top of this $400 \mathrm{~cm}$ long core contains muddy peat from the surface to a depth of $40 \mathrm{~cm}$. At $40 \mathrm{~cm}$ it grades into peaty mud which has a gradual lower contact at $71 \mathrm{~cm}$. The peaty mud grades into slightly peaty mud which extends down to 180 $\mathrm{cm}$. At $180 \mathrm{~cm}$ there is slightly sandy peat with a sharp upper contact and a gradual lower contact at $255 \mathrm{~cm}$. It grades into muddy peat to a depth of $267 \mathrm{~cm}$. At $267 \mathrm{~cm}$ the muddy peat grades into peaty mud which continues down to 280 $\mathrm{cm}$. The peaty mud grades down into slightly peaty mud which extends to $360 \mathrm{~cm}$. At $360 \mathrm{~cm}$ there is a slightly muddy sand layer which has a sharp upper contact and a gradual lower contact at $372 \mathrm{~cm}$ where it grades into slightly peaty mud. 
This slightly peaty mud extends to the end of the core at 400 $\mathrm{cm}$. This core contains two possible abruptly buried peats suggested by the sharp upper contacts at depths of $180 \mathrm{~cm}$ and $372 \mathrm{~cm}$.

Core 420- This core was taken $0.3 \mathrm{~km}(0.18 \mathrm{mi})$ northeast of core 421, on the east side of Pony Creek. It is $400 \mathrm{~cm}$ long. It consists of muddy peat from the surface to a depth of $60 \mathrm{~cm}$ where there is a gradual lower contact. The muddy peat grades into a slightly peaty mud which extends to a depth of $78 \mathrm{~cm}$. At $78 \mathrm{~cm}$ there is peaty mud with a sharp upper contact and a gradual lower contact at $143 \mathrm{~cm}$. The peaty mud grades into slightiy peaty mud which continues down to $155 \mathrm{~cm}$. At $155 \mathrm{~cm}$ of depth a muddy peat with a sharp upper contact is seen. It has a gradual lower contact at 192 $\mathrm{cm}$ where it grades into peaty mud which extends to a depth of $255 \mathrm{~cm}$. Muddy peat with a sharp upper contact and a gradual lower contact is evident from $255 \mathrm{~cm}$ to $270 \mathrm{~cm}$. At $270 \mathrm{~cm}$ it grades into peaty mud which has a gradual lower contact at $293 \mathrm{~cm}$. The peaty mud grades into a mix of sand and mud which extends to the end of the core at $400 \mathrm{~cm}$. This core contains possibly three episodically buried wetlands with sharp upper contacts at depths of $78 \mathrm{~cm}, 155 \mathrm{~cm}$, and $255 \mathrm{~cm}$. Core 470 (figure 15) - This core was taken on the west side of Pony Creek, due west of core 420 . It is $375 \mathrm{~cm}$ in length. The top portion of the core from the surface to a depth of $62 \mathrm{~cm}$ is peat. Within this peat, at $43 \mathrm{~cm}$ down 
core, there is an oxidized zone which may represent a burial event. From $62 \mathrm{~cm}$ to $65 \mathrm{~cm}$ there is a slightly peaty mud which has a very distinct sharp upper contact. It has a gradual lower contact at $65 \mathrm{~cm}$ where it grades into peaty mud which also has a gradual lower contact. This peaty mud dates at $1,020 \pm 70$ RCYBP. From $78 \mathrm{~cm}$ the peaty mud grades into slightly peaty mud which extends down to $116 \mathrm{~cm}$. At $116 \mathrm{~cm}$ there is peaty mud which dates at $1,400 \pm 80$ RCYBP. This peaty mud has a sharp upper contact and a gradual lower contact at $132 \mathrm{~cm}$ where it grades into slightly peaty mud. From $181 \mathrm{~cm}$ to $223 \mathrm{~cm}$ there is muddy peat with a distinct sharp upper contact and a gradual lower contact. This muddy peat is dated at $1,660 \pm 80 \mathrm{RCYBP}$. At $223 \mathrm{~cm}$ it grades into slightly peaty mud which extends to $240 \mathrm{~cm}$ where there is a gradual lower contact. From $240 \mathrm{~cm}$ to $246 \mathrm{~cm}$ there is a thin sand layer. At $246 \mathrm{~cm}$ there is muddy peat with a sharp upper contact and a gradual lower contact at $265 \mathrm{~cm}$. This muddy peat is dated at 2,900 \pm 80 RCYBP. The muddy peat grades into slightly peaty mud which continues down to $300 \mathrm{~cm}$ where there is a gradual lower contact. At this point it grades into peaty mud which dates at $3,700 \pm 90$ RCYBP. The peaty mud extends to $318 \mathrm{~cm}$ where there is a gradual contact. At $318 \mathrm{~cm}$ it grades into slightly peaty mud which continues down to the end of the core at $377 \mathrm{~cm}$. This core contains five distinct episodically buried peats at depths of $65 \mathrm{~cm}, 116$ $\mathrm{cm}, 181 \mathrm{~cm}, 246 \mathrm{~cm}$, and $300 \mathrm{~cm}$. The oxidized zone seen near 
the top of the core may also represent a burial event (figure 16) when a supratidal soil was subsequently submerged and buried by a high marsh.

core 419- This $510 \mathrm{~cm}$ long core was taken within one meter of core 470 . It is identical to core 470 to the point where core 470 ends at $375 \mathrm{~cm}$. At $375 \mathrm{~cm}$ in core 419 there is peaty mud with a sharp upper contact and a gradual lower contact at $413 \mathrm{~cm}$. At this point the peaty mud grades into slightly peaty mud which extends to $460 \mathrm{~cm}$. At $460 \mathrm{~cm}$ there is a gradual lower contact where the slightly peaty mud grades into mud. This mud continues down to 477 where it grades into sand. The sand extends to the end of the core at $510 \mathrm{~cm}$. Core 419 records one additional event to those seen in core 470 .

Within the Pony Slough area, the cluster of cores 470 , 419, 420, and 421 all contain evidence of episodically buried peats. One kilometer to the southwest of this cluster is the group of cores 451,452, 453, and 454. This group shows no evidence of episodically buried peats. The group of cores 413, 414, and 455 which is north and slightly east of the cluster also contain no evidence of episodic peat burial. The relationship of these cores to each other suggests the presence of very active local structures running north northwest across pony Slough. Subsidence is distinctly recorded in the center cluster of cores, but not on those cores outside this cluster. 


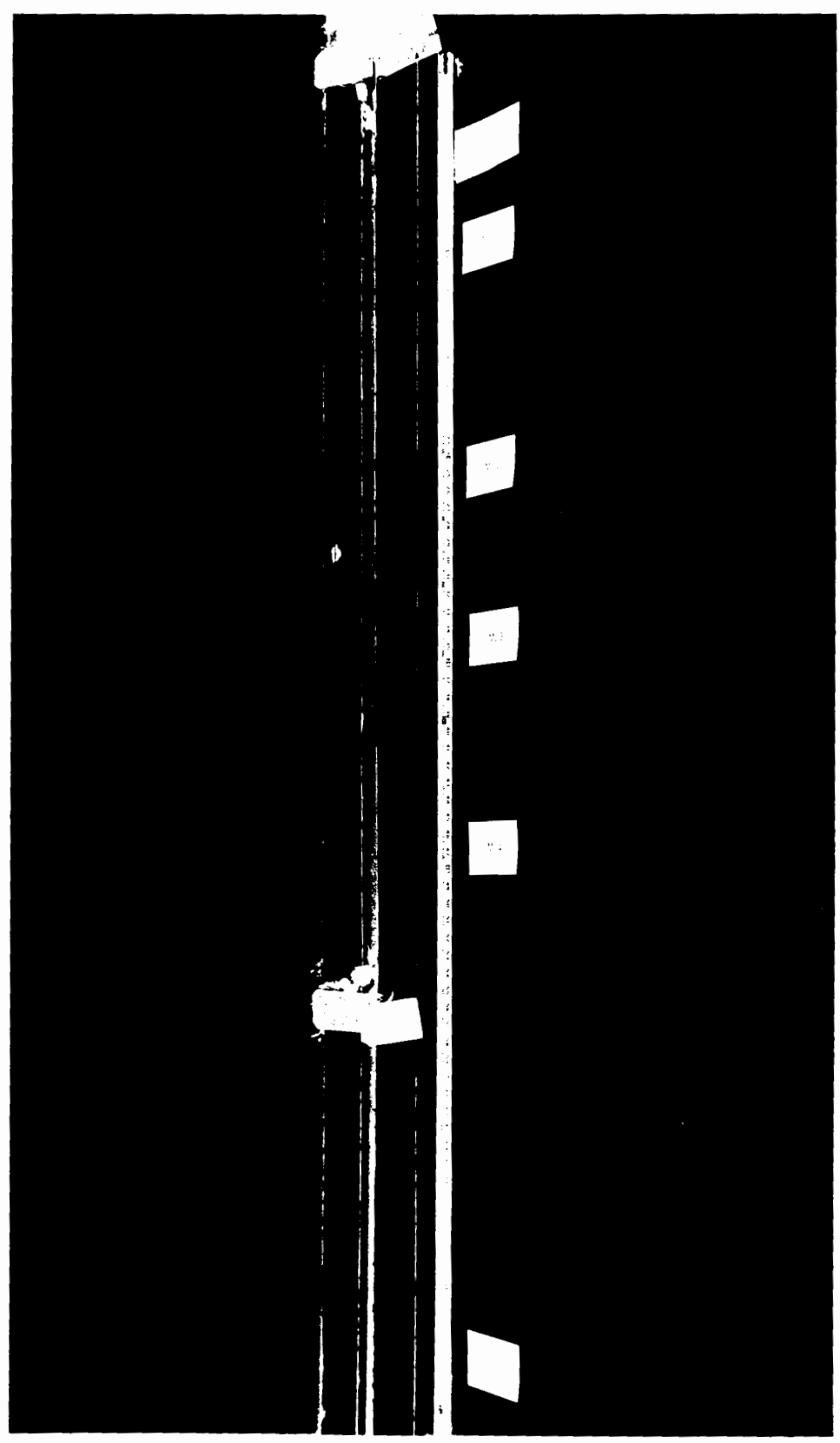

Figure 16. Photograph showing the five distinct episodically buried peats of core 470 from Pony Slough, Coos Bay, Oregon. These buried peats $C$ - 14 dated at $1020 \pm 70,1400 \pm 80,1660 \pm 80,2900 \pm 80$ and $3700 \pm 90$ RCYBP (from top to bottom). The oxidized zone seen above Mu1 (buried marsh unit) near the top of the core may also represent a burial event. 
Coalbank Slough Cores - 456, 457, 458, 459,478

This area is $11.7 \mathrm{~km}(7.1 \mathrm{mi})$ due east of the ocean and contains tidal and freshwater marshes. Cores 456, 457, 458, and 459 were taken from a tidal marsh $0.5 \mathrm{~km}(0.31 \mathrm{mi})$ south of the radio station $\mathrm{KCBY}$.

Core 456- This core is $300 \mathrm{~cm}$ long. From the surface to a depth of $45 \mathrm{~cm}$ it contains peaty mud with a gradual contact. The peaty mud grades into slightly peaty mud which has a gradual lower contact at $57 \mathrm{~cm}$. It grades into peaty mud which continues to $65 \mathrm{~cm}$ where it grades into slightly peaty mud which contains three thin sand layers. These sand layers appear at depths of $147 \mathrm{~cm}, 163 \mathrm{~cm}$ and $198 \mathrm{~cm}$. This slightly peaty mud extends down to $277 \mathrm{~cm}$ where it grades into mud which continues to the end of the core at $300 \mathrm{~cm}$. This core contains varying amounts of peat from the surface to $277 \mathrm{~cm}$. There is evidence of one possible buried peat at a depth of $57 \mathrm{~cm}$.

Core 457- The top of this $185 \mathrm{~cm}$ long core contains peaty mud with a gradual lower contact at $40 \mathrm{~cm}$. The peaty mud grades into slightly peaty mud which continues to a depth of $52 \mathrm{~cm}$. At $52 \mathrm{~cm}$ there is muddy peat with a sharp upper contact and a gradual lower contact. The gradual lower contact is at $70 \mathrm{~cm}$ where the muddy peat grades into peaty 
mud. The peaty mud extends down to $90 \mathrm{~cm}$ where it grades into slightly peaty mud which continues to the bottom of the core at $185 \mathrm{~cm}$. This slightly peaty mud contains three thin sand layers. These sand layers appear at depths of $112 \mathrm{~cm}$, $125 \mathrm{~cm}$, and $135 \mathrm{~cm}$. The origins of these thin sand layers are unknown; but their presence denotes some form of episodic flooding. The core is primarily varying amounts of peat and contains evidence of a buried peat at a depth of $52 \mathrm{~cm}$.

Core 458- This $300 \mathrm{~cm}$ long core consists of muddy peat from the surface to a depth of $50 \mathrm{~cm}$. The muddy peat has a gradual lower contact where it grades into peaty mud which extends down to $72 \mathrm{~cm}$. At $72 \mathrm{~cm}$ there is mud which has a sharp upper contact and a gradual lower contact at $100 \mathrm{~cm}$. Peaty mud is seen at $100 \mathrm{~cm}$. It extends down to $118 \mathrm{~cm}$. At $118 \mathrm{~cm}$ there is mud with a sharp upper contact. The mud continues down to the end of the core at $300 \mathrm{~cm}$. This mud contains three intervals of detrital material which may be the result of floods, storm tidal surges, or tsunami. There is evidence of one burial event at a depth of $100 \mathrm{~cm}$.

Core 459- This core was taken $10 \mathrm{~m}$ north of core 458 and records the same sequence.

Core 478 (figure 15)- This core was taken from a freshwater tidal marsh at the extreme south end of coalbank Creek approximately $1 \mathrm{~km}(0.61 \mathrm{mi})$ south of Libby. It is 400 $\mathrm{cm}$ long and contains peat from the surface to a depth of 60 $\mathrm{cm}$ where there is a gradual contact. The peat grades into 
mud which extends down to $132 \mathrm{~cm}$. At $132 \mathrm{~cm}$ there is a continuous muddy peat with a sharp upper contact. The top portion of this core dates at $1740 \pm 100$ RCYBP. This muddy peat extends to the end of the core at $400 \mathrm{~cm}$. The basal core date is $2,920 \pm 60$ RCYBP. Although this core records one buried event at $132 \mathrm{~cm}$ depth, it is essentially a continuous peaty core throughout the rest of its length.

\section{Shinglehouse Slough Core -460}

Core 460- This core was taken at the south end of Shinglehouse slough in a tidally controlled marsh. It is $14.5 \mathrm{~km}(8.8 \mathrm{mi})$ due east of the ocean. The core is $500 \mathrm{~cm}$ long. The top portion consists of peaty mud from the surface to a depth of $107 \mathrm{~cm}$ where there is a gradual contact. At $107 \mathrm{~cm}$ it grades into a peaty mud layered with mud throughout which extends down to $338 \mathrm{~cm}$ where it grades into peaty mud. The peaty mud continues down core to $371 \mathrm{~cm}$ where it grades into slightly peaty mud. The slightly peaty mud extends to the end of the core at $500 \mathrm{~cm}$. This core is composed primarily of peaty material throughout its length of $500 \mathrm{~cm}$ and shows no evidence of abrupt submergence.

\section{White Point Core -463}


Point. Seven cores were taken along the north edge of white point. They were all nearly identical and so were logged as the single core 463. This core is $250 \mathrm{~cm}$ on length. All contacts in the core are gradual. From the surface down to $30 \mathrm{~cm}$ there is peaty mud. At $30 \mathrm{~cm}$ this peaty mud grades into sand which extends to $160 \mathrm{~cm}$. The sand grades into bay mud which continues to the end of the core at $250 \mathrm{~cm}$. This core represents a typical mid-channel sand bar deposit.

\section{Catching slough core - 412}

This core was taken from a tidally controlled marsh on the east side of Catching Slough, $6 \mathrm{~km}(3.7 \mathrm{mi})$ south of White point, at the inside bend of a meandering section of Catching Slough.

Core 412- This core is $600 \mathrm{~cm}$ long. The top $35 \mathrm{~cm}$ were not recovered. From $35 \mathrm{~cm}$ down to $85 \mathrm{~cm}$ there is mud which grades into peaty mud which continues down to $95 \mathrm{~cm}$. At 95 $\mathrm{cm}$ the peaty mud grades into peat. The peat extends to 125 $\mathrm{cm}$ where it grades into muddy peat. The muddy peat grades down into mud at $160 \mathrm{~cm}$. From $160 \mathrm{~cm}$ to $214 \mathrm{~cm}$ there is mud. At $214 \mathrm{~cm}$ there is peaty mud with a sharp upper contact and a gradual lower contact at $235 \mathrm{~cm}$ where it grades into mud. The mud extends to $280 \mathrm{~cm}$. At this point the mud grades down into peaty mud which extends to $300 \mathrm{~cm}$. Here, it grades into mud. The mud continues down to $340 \mathrm{~cm}$ where it grades into 
peaty mud. From $340 \mathrm{~cm}$ to $352 \mathrm{~cm}$ there is peaty mud. The peaty mud grades down into mud which extends to $400 \mathrm{~cm}$. At $400 \mathrm{~cm}$ the mud grades into peaty mud. This peaty mud is present to a depth of $483 \mathrm{~cm}$ where it grades into mud. This mud continues down to the bottom of the core at $600 \mathrm{~cm}$. One possible explanation for the stratigraphy observed in this core is that it contains multiple buried peats that did not submerge enough to show strong environmental changes. That is to say, subsidence events of less than $0.5 \mathrm{~m}$.

\section{Voge1 Creek Cores - 410, 411}

Vogel Creek is $17.5 \mathrm{~km}(10.7 \mathrm{mi})$ due east of the ocean. The cores were taken from pasture land. This area is the ancient flood plain of the coos River.

Core 410- This core is $300 \mathrm{~cm}$ long and contains mud from the surface to a depth of $88 \mathrm{~cm}$. There are small amounts of sand mixed in the mud. From $88 \mathrm{~cm}$ to $100 \mathrm{~cm}$ there is detrital material which has a sharp upper and a sharp lower contact. At $100 \mathrm{~cm}$ there is slightly peaty mud which extends to $170 \mathrm{~cm}$ where it grades into peaty mud. The peaty mud continues down core to a depth of $190 \mathrm{~cm}$. Here, it grades into a slightly peaty mud which extends down to $204 \mathrm{~cm}$. At this point it grades into peaty mud which is present to the end of the core at $300 \mathrm{~cm}$. This core has at least one buried 
peat at a depth of $100 \mathrm{~cm}$ and then a continuous peaty sequence for a length of $200 \mathrm{~cm}$. However, a possible weak submergence event might also be present at $170 \mathrm{~cm}$.

Core 411 - This core was taken $1 \mathrm{~km}(0.61 \mathrm{mi})$ upstream from core 410. It is $220 \mathrm{~cm}$ in length and contains mud from the surface to a depth of $90 \mathrm{~cm}$ where it grades into slightly peaty mud. The slightly peaty mud continues down to $148 \mathrm{~cm}$ where it grades into muddy peat. The muddy peat extends down core to $160 \mathrm{~cm}$. At $160 \mathrm{~cm}$ there is sandy mud with a sharp upper contact and a gradual lower contact at $170 \mathrm{~cm}$ where it grades into sand which continues to the end of the core at $220 \mathrm{~cm}$.

\section{Smith Ranch Cores - 406, 461,466,467,468,469}

These cores were taken $20 \mathrm{~km}(12.2 \mathrm{mi})$ due east of the ocean in a pasture. The cores were taken at varying distances from a small tidal creek with runs through the center of the pasture. The tidal flooding in the creek and adjoining pasture land is now controlled by a tidal flood gate.

Core 406- This core is $430 \mathrm{~cm}$ long. All contacts are gradual. From the surface down to $35 \mathrm{~cm}$ there is peat. At $35 \mathrm{~cm}$ it grades into peaty mud which contains slight amounts of sand. This peaty mud extends to $183 \mathrm{~cm}$ where it grades 
into sandy mud which continues to a depth of $200 \mathrm{~cm}$. At 200 $\mathrm{cm}$ it grades into peaty mud which is present down to $388 \mathrm{~cm}$. From $388 \mathrm{~cm}$ to the end of the core, the peaty mud grades into a sandy mud.

Core 461 - This core is $245 \mathrm{~cm}$ long. The top to a depth of $35 \mathrm{~cm}$ was not recovered. From $35 \mathrm{~cm}$ down to $150 \mathrm{~cm}$ there is slightly peaty mud mixed with small amounts of sand. At $150 \mathrm{~cm}$ there is peaty mud with a sharp upper contact and a gradual lower contact. From $185 \mathrm{~cm}$ the peaty mud grades into slightly peaty mud which is found to the bottom of the core at $245 \mathrm{~cm}$. This core records at least one subsidence event of $150 \mathrm{~cm}$ depth.

Core 466 - This core is $400 \mathrm{~cm}$ long and contains peat from the surface to a depth of $22 \mathrm{~cm}$. At $22 \mathrm{~cm}$ it grades into slightly sandy mud. The slightly sandy mud extends to $59 \mathrm{~cm}$ where it grades into slightly peaty mud to a depth of $97 \mathrm{~cm}$. At $97 \mathrm{~cm}$ there is mud with a sharp upper contact that extends to a depth of $205 \mathrm{~cm}$. This mud is mixed with small amounts of sand between $130 \mathrm{~cm}$ and $155 \mathrm{~cm}$. From $205 \mathrm{~cm}$ to $214 \mathrm{~cm}$ there is muddy peat with sharp upper and lower contacts. Between $214 \mathrm{~cm}$ and $223 \mathrm{~cm}$ is sand with a small amount of detrital material. From $223 \mathrm{~cm}$ to $238 \mathrm{~cm}$ there is muddy peat with sharp upper and lower contacts. At $238 \mathrm{~cm}$ mud extends downward to a depth of $269 \mathrm{~cm}$. From $269 \mathrm{~cm}$ there is muddy peat with a sharp upper contact and a gradual lower contact. This muddy peat grades into a slightly peaty 
mud at $273 \mathrm{~cm}$ which extends to $295 \mathrm{~cm}$ where the slightly peaty mud grades into mud to a depth of $335 \mathrm{~cm}$. Between 335 $\mathrm{cm}$ and $350 \mathrm{~cm}$ there is muddy peat with sharp upper and lower contacts. At $350 \mathrm{~cm}$ mud extends to the end of core at $400 \mathrm{~cm}$. This core contains evidence of four (possibly five) abruptly buried peats at depths of $59 \mathrm{~cm}, 205 \mathrm{~cm}, 223 \mathrm{~cm}, 269 \mathrm{~cm}$, and $335 \mathrm{~cm}$. This centrally located core site appears to be most sensitive record of episodic submergence in the Smith pasture area.

Core 467- This core is $400 \mathrm{~cm}$ long. There is slightly peaty mud from the surface down core to $100 \mathrm{~cm}$. At $100 \mathrm{~cm}$ there is slightly muddy sand containing some detrital material. It has a sharp upper contact and extends to a depth of $143 \mathrm{~cm}$. At this point there is a $2 \mathrm{~cm}$ thick layer of peaty mud with a sharp upper contact. From $145 \mathrm{~cm}$ to 150 cm a sand layer with a sharp upper contact is evident. At $150 \mathrm{~cm}$ the sand grades into slightly peaty mud which continues down to $240 \mathrm{~cm}$. This slightly peaty mud contains very small amounts of sand. It grades into muddy peat which extends down core to $258 \mathrm{~cm}$ where it grades into slightly peaty mud which contains some sand. It has a gradual lower contact. At $280 \mathrm{~cm}$ there is slightly muddy sand. The sand is present down to $285 \mathrm{~cm}$. From $285 \mathrm{~cm}$ to $290 \mathrm{~cm}$ there is slightly peaty mud with a sharp upper contact and a sharp lower contact. A mixed sand and mud layer with slight 
amounts of peat and detrital material extends from $290 \mathrm{~cm}$ to the end of the core at $400 \mathrm{~cm}$.

Core 468- The top portion of this $400 \mathrm{~cm}$ long core was not recovered. From $60 \mathrm{~cm}$ to $156 \mathrm{~cm}$ there is slightly sandy mud with a gradual lower contact. At $156 \mathrm{~cm}$ there is peaty mud which extends to $174 \mathrm{~cm}$. The section of the core between $174 \mathrm{~cm}$ and $200 \mathrm{~cm}$ was not recovered. From $200 \mathrm{~cm}$ to $232 \mathrm{~cm}$ there is slightly sandy mud with a gradual lower contact. It grades into slightly peaty mud which extends to a depth of $285 \mathrm{~cm}$ where there is a gradual contact. From $285 \mathrm{~cm}$ to 321 $\mathrm{cm}$ slightly muddy sand is evident. At $321 \mathrm{~cm}$ there is slightly peaty mud containing small amounts of sand. It has a sharp upper contact and a gradual lower contact. It extends to a depth of $375 \mathrm{~cm}$ where it grades into muddy sand. The muddy sand continues down to the bottom of the core at 400 $\mathrm{cm}$.

Cores 467 and 468 were taken at the edge of the pasture near the hillside slopes, which are subject to debris flows and subject to slope instability. In addition, the higher elevations of these upstream sites has possibly diminished their susceptibility to tidal flooding.

Core 469- Of all the cores from the Smith Ranch area, this core was taken nearest to the coos River $10.6 \mathrm{~km}$ or 0.37 $\mathrm{mi}$ south of the river). It is $410 \mathrm{~cm}$ long. The top $30 \mathrm{~cm}$ of the core were not recovered. At $30 \mathrm{~cm}$ there is slightly peaty mud containing some sand. It grades into sandy mud at 
$127 \mathrm{~cm}$. The sandy mud extends down to $150 \mathrm{~cm}$. From $150 \mathrm{~cm}$ to 158 there is muddy peat with a sharp upper contact and a gradual lower contact. At $158 \mathrm{~cm}$ the muddy peat grades into peaty mud which continues down core to $175 \mathrm{~cm}$ where there is a gradual lower contact. At $175 \mathrm{~cm}$ there are $3 \mathrm{~cm}$ of slightly muddy sand. The muddy sand grades into slightly peaty mud which extends to $228 \mathrm{~cm}$. The lower contact is gradual. From $228 \mathrm{~cm}$ to $340 \mathrm{~cm}$ there is peaty mud. At 340 cm slightly muddy sand with a sharp upper contact and a sharp lower contact is seen. Slightly peaty sand with abundant detrital material is evident from $355 \mathrm{~cm}$ to $382 \mathrm{~cm}$. At 382 cm there is slightly peaty mud with a sharp upper contact and a sharp lower contact. It extends down to $400 \mathrm{~cm}$. The remainder of the core is sand. Core 469 records three abrupt burial events at depths of $150 \mathrm{~cm}, 178 \mathrm{~cm}$, and $355 \mathrm{~cm}$.

\section{Milicoma River Cores - 444, 443,442, 441}

The Millicoma River flows into the coos River $20 \mathrm{~km}$ $(12.2 \mathrm{mi})$ due east of the ocean. The cores were taken from wide tidal marshes and pastures on both sides of the river. At this distance from the coast the tidal influence relative to river influence is greatly diminished. As a result, it is difficult to separate out sea level changes from river flooding processes. However, some core logs are suggestive of past burial events and so are reported below. 
Core 444- This core was taken on the east side of the Millicoma River east of Landrifth Bridge Road. It was taken at the point where a small stream enters the river. This 500 $\mathrm{cm}$ long core contains slightly peaty mud from the surface down to $82 \mathrm{~cm}$. From $82 \mathrm{~cm}$ to $100 \mathrm{~cm}$ there is peat with a sharp upper contact and a gradual lower contact. It grades into muddy peat which has a gradual lower contact at $300 \mathrm{~cm}$. The muddy peat grades into peaty mud which extends down to $335 \mathrm{~cm}$ where there is a gradual contact. It grades down into slightly peaty mud which continues to a depth of $365 \mathrm{~cm}$. At $365 \mathrm{~cm}$ there is peaty mud with a sharp upper contact and a gradual contact lower contact at $450 \mathrm{~cm}$. The peaty mud grades into slightly peaty mud which continues down to the end of the core at $500 \mathrm{~cm}$. The core shows evidence of two episodically buried peat sequences at depths of $82 \mathrm{~cm}$ and 365 $\mathrm{cm}$.

Core 443- This core was taken $25 \mathrm{~m}$ south of core 444 . It is $285 \mathrm{~cm}$ long. It contains slightly peat mud with some sand from the surface to a depth of $95 \mathrm{~cm}$ where there is a gradual lower contact. It grades into muddy sand. At $100 \mathrm{~cm}$ there is peaty mud with an undetermined upper contact and a sharp lower contact at $160 \mathrm{~cm}$. Muddy peat is evident from $160 \mathrm{~cm}$ to $190 \mathrm{~cm}$ where it grades into peaty mud. The peaty mud continues to a depth of $200 \mathrm{~cm}$. It grades into slightly peaty mud which extends to the end of the core at $285 \mathrm{~cm}$. 
This core contains one buried peat sequence at a depth of 100 $\mathrm{cm}$.

Core 442- This core was taken $21.7 \mathrm{~km}(13.2 \mathrm{mi})$ due east of the ocean and $1.6 \mathrm{~km}(0.98 \mathrm{mi})$ upstream from core 444 . It was taken from a pasture on the north side of the Millicoma River. The top of this $500 \mathrm{~cm}$ long core consists of peaty mud from the surface down to $38 \mathrm{~cm}$. It grades into slightly peaty mud which extends to $98 \mathrm{~cm}$. From $98 \mathrm{~cm}$ to $190 \mathrm{~cm}$ there is muddy peat with a sharp upper contact and a gradual lower contact. At $190 \mathrm{~cm}$ the muddy peat grades into slightly peaty mud to a depth of $250 \mathrm{~cm}$. At $250 \mathrm{~cm}$ there is peaty mud with a gradual upper contact and a gradual lower contact. The lower contact is at $265 \mathrm{~cm}$. The peaty mud grades into slightly peaty mud which continues down to $292 \mathrm{~cm}$. At $292 \mathrm{~cm}$ there is muddy peat with a sharp upper contact and a gradual lower contact at $325 \mathrm{~cm}$. It grades into slightly peaty mud down to $363 \mathrm{~cm}$. From $363 \mathrm{~cm}$ to $405 \mathrm{~cm}$ peaty mud with a sharp upper contact and a gradual lower contact is evident. From $405 \mathrm{~cm}$ to the end of the core at $500 \mathrm{~cm}$ there is slightly peaty mud. This core might record three, possibly four episodically buried peat sequences. These buried peat sequences occur at depths of $98 \mathrm{~cm}, 250 \mathrm{~cm}, 292 \mathrm{~cm}$, and 363 $\mathrm{cm}$.

Core 441- This core was taken $2.5 \mathrm{~km}$ (0.37 mi) upstream on the west side of Millicoma River. It was taken $24 \mathrm{~km}$ $(14.6 \mathrm{mi})$ due east of the ocean. It is $400 \mathrm{~cm}$ long and 
contains peaty mud from the surface to $50 \mathrm{~cm}$ where it grades into slightly peaty mud. The slightly peaty mud extends down to $109 \mathrm{~cm}$. It grades into mud which has a gradual lower contact at $118 \mathrm{~cm}$. The mud grades into slightly peaty mud to a depth of $179 \mathrm{~cm}$. At $179 \mathrm{~cm}$ there is peaty mud which has a sharp upper contact and a gradual lower contact. At $188 \mathrm{~cm}$ it grades into slightly peaty mud which continues down to 208 $\mathrm{cm}$. At $208 \mathrm{~cm}$ the slightly peaty mud grades into mud. The mud extends down to $263 \mathrm{~cm}$. From $263 \mathrm{~cm}$ to $273 \mathrm{~cm}$ there is peaty mud with a sharp upper contact and a gradual lower contact. At $273 \mathrm{~cm}$ the peaty mud grades into slightly peaty mud to a depth of $276 \mathrm{~cm}$. At $276 \mathrm{~cm}$ there is muddy peat with a sharp upper contact and a gradual lower contact at $290 \mathrm{~cm}$. Here, it grades into slightly peaty mud. At $302 \mathrm{~cm}$ the slightly peaty mud grades into peaty mud which continues down to $351 \mathrm{~cm}$ where there is a gradual lower contact. From 351 $\mathrm{cm}$ to $391 \mathrm{~cm}$ slightly peaty mud is evident. At $391 \mathrm{~cm}$ there is peaty mud with a sharp upper contact and a gradual lower contact. From $395 \mathrm{~cm}$ to the end of the core at $400 \mathrm{~cm}$ there is slightly peaty mud. This core apparently shows evidence of four episodically buried peat sequences at depths of 179 $\mathrm{cm}, 263 \mathrm{~cm}, 276 \mathrm{~cm}$, and $391 \mathrm{~cm}$.

Daniels Creek Cores $-407,464,465,446,445$

Daniels Creek is $21.7 \mathrm{~km}$ (13.2 mi) due east of the ocean 
and flows into the coos River. With the exception of core 445, these cores were taken approximately $1.8 \mathrm{~km}$ (1.1 $\mathrm{mi}$ ) upstream from the point where the creek enters the coos River. The mouth of Daniels creek is regularly influenced by daily tides. However, tidal influence in the marshes of Daniels Creek diminishes upstream as a result of tidal gates and elevated flood plain deposits.

Core 407- This core is $600 \mathrm{~cm}$ long. All contacts in the core are gradual. The top portion of the core from the surface to a depth of $20 \mathrm{~cm}$ is muddy peaty. The muddy peat grades down into peaty mud which extends down to $75 \mathrm{~cm}$. It grades into peat. The peat continues down core to $185 \mathrm{~cm}$ where it grades into muddy peat. This muddy peat extends to a depth of $318 \mathrm{~cm}$. It grades into peaty mud. The peaty mud is present to a depth of $350 \mathrm{~cm}$ where it grades into peat. The peat continues down to $405 \mathrm{~cm}$. At this point it grades into peaty mud which extends to $420 \mathrm{~cm}$. At $420 \mathrm{~cm}$ the peaty mud grades into peat. This peat is evident down to $482 \mathrm{~cm}$. Here, it grades into muddy peat which extends down core to $510 \mathrm{~cm}$. At $510 \mathrm{~cm}$ this muddy peat grades into mud. The mud extends to the end of the core at $600 \mathrm{~cm}$. This core apparently contains three distinct buried peat sequences at depths of $75 \mathrm{~cm}, 350 \mathrm{~cm}$, and $420 \mathrm{~cm}$.

Core 464-All contacts in this $125 \mathrm{~cm}$ long core are gradual. It contains muddy peat from the surface down to 30 
cm. Here, it grades into slightly peaty mud. The slightly peaty mud extends to $43 \mathrm{~cm}$ where it grades into mud. This mud continues to a depth of $60 \mathrm{~cm}$ and grades into slightly peat mud. At $65 \mathrm{~cm}$ the slightly peaty mud grades into peaty mud which extends to $75 \mathrm{~cm}$. At $75 \mathrm{~cm}$ it grades into slightly peaty mud which contains small amounts of detrital material. This extends to $97 \mathrm{~cm}$ where it grades into peaty mud which has a slight amount of detrital material. At $115 \mathrm{~cm}$ the peaty mud grades into mud which contains some detrital material. This mud continues to the end of the core at 125 $\mathrm{cm}$. There is evidence of two possible buried peat sequence in this core at depths of $65 \mathrm{~cm}$ and $97 \mathrm{~cm}$.

Core 465- This core is $420 \mathrm{~cm}$ in length. From the surface to a depth of $35 \mathrm{~cm}$ this core consists of peaty mud. The peaty mud grades into mud which is seen to a depth of 55 $\mathrm{cm}$. At $55 \mathrm{~cm}$ the mud grades into slightly peaty mud which extends down to $65 \mathrm{~cm}$. At $65 \mathrm{~cm}$ there is peaty mud with a sharp upper contact and a gradual lower contact. This peaty mud dates at $1,970 \pm 70 \mathrm{RCYBP}$. At $69 \mathrm{~cm}$ it grades into slightly peaty mud which continues down to $90 \mathrm{~cm}$. Peaty mud with a sharp upper contact and a gradual lower contact is evident from $90 \mathrm{~cm}$ to $128 \mathrm{~cm}$. This peaty mud dates at 3,080 $\pm 60 \mathrm{RCYBP}$. At $128 \mathrm{~cm}$ it grades into slightly peaty mud which extends to a depth of $153 \mathrm{~cm}$. At $153 \mathrm{~cm}$ it grades into peaty mud. The peaty mud is evident down to $195 \mathrm{~cm}$ where it grades into slightly peaty mud. The slightly peaty mud 
continues down to $232 \mathrm{~cm}$. At this point it grades down into peaty mud which extends to $238 \mathrm{~cm}$. The peaty mud grades into slightly peaty mud. At $242 \mathrm{~cm}$ the slightly peaty mud grades inco peaty mud which is found to a depth of $249 \mathrm{~cm}$. Here, the peaty mud grades into slightly peaty mud with a small amount of detrital material. This continues down to $265 \mathrm{~cm}$ where it grades into peaty mud. At $269 \mathrm{~cm}$ the peaty mud grades into slightly peaty mud which contains a little detrital material to a depth of $300 \mathrm{~cm}$. The slightly peaty mud grades into peaty mud which is present down to $340 \mathrm{~cm}$. At $340 \mathrm{~cm}$ the peaty mud grades into slightly peaty mud which continues down to $360 \mathrm{~cm}$. Here, the slightly peaty mud grades into mud which contains a slight amount of detrital material. This muds extends down to $408 \mathrm{~cm}$. At $408 \mathrm{~cm}$ to the end of the core at $420 \mathrm{~cm}$ there is carbonized wood which dates at $4560 \pm 70$ RCYBP. This core apparently records at least five episodically buried peats. The lack of sharp upper contacts of the peaty units in this and adjacent cores in Daniels Creek might reflect a delayed response of freshwater marsh plants to initial prolonged submergence. For example, cattails and carex marshes were observed to be thriving in standing water (mid-summer season) in several diked and flooded pastures in the Daniels Creek marsh system. The buried peats in core 405 occur at depths of $65 \mathrm{~cm}, 90 \mathrm{~cm}$, $153 \mathrm{~cm}, 232 \mathrm{~cm}$, and $300 \mathrm{~cm}$. 
Core 446- This core was taken $200 \mathrm{~m}$ upstream from core 465. It is $400 \mathrm{~cm}$ long. The top $38 \mathrm{~cm}$ of the core were not recovered. From $38 \mathrm{~cm}$ to $130 \mathrm{~cm}$ it contains muddy peat/peaty mud. At $130 \mathrm{~cm}$ there is mud with a sharp upper contact and a gradual lower contact at $142 \mathrm{~cm}$. The mud grades into muddy peat which extends to a depth of $205 \mathrm{~cm}$. At $205 \mathrm{~cm}$ this muddy peat grades into peaty mud. The peaty mud continues down to $215 \mathrm{~cm}$ where it grades into peat which contains a small amount of detrital material. At $242 \mathrm{~cm}$ the peat grades into muddy peat which extends to $250 \mathrm{~cm}$. Here, the muddy peat grades into slightly peaty mud which continues down core to $281 \mathrm{~cm}$. At $281 \mathrm{~cm}$ there is mud which contains small amounts of detrital material and sand and has a sharp upper contact and a sharp lower contact. From $295 \mathrm{~cm}$ to $340 \mathrm{~cm}$ there is slightly peaty mud which has a gradual lower contact. It grades into peaty mud which continues down to $375 \mathrm{~cm}$. At this point the peaty mud grades into muddy peat which extends to the end of the core at $400 \mathrm{~cm}$. There is evidence of at least three episodically buried peat sequences in this core, at depths of $142 \mathrm{~cm}, 215 \mathrm{~cm}$, and $295 \mathrm{~cm}$.

Core 445- This core was taken $1.2 \mathrm{~km}(0.73 \mathrm{mi})$ upstream from core 446 on a meandering section of Daniels Creek. It is $400 \mathrm{~cm}$ long. The top $25 \mathrm{~cm}$ of the core was not recovered. From $25 \mathrm{~cm}$ to the end of core there is very sightly peaty mud which contains two mud and sand layers at $95 \mathrm{~cm}$ to $115 \mathrm{~cm}$ and $173 \mathrm{~cm}$ to $200 \mathrm{~cm}$ down core. This core clearly reflects 
the effects of lateral stream migration, and is an unreliable indicator of possible episodic subsidence.

\section{Coos River Cores $-447,405$}

Core 447- This core was taken $23.9 \mathrm{~km}(14.6 \mathrm{mi})$ due east of the ocean, on the south side of the coos River. It was taken from a sand flat. It is $400 \mathrm{~cm}$ long and contains channel sand for its entire length.

Core 405- This core was also taken $23.9 \mathrm{~km}$ (14.6 mi) due east of the ocean. It was taken $0.6 \mathrm{~km}(0.37 \mathrm{mi})$ north of the Coos River near Rogers Creek. It is $385 \mathrm{~cm}$ long. All contacts in the core are gradual. The top portion of the core contains peat from the surface down to $30 \mathrm{~cm}$. At $30 \mathrm{~cm}$ the peat grades into peaty mud which extends down to $50 \mathrm{~cm}$. Here, the peaty mud grades into mud. At $90 \mathrm{~cm}$ the mud grades into peaty mud which continues down to $230 \mathrm{~cm}$. At $230 \mathrm{~cm}$ the peaty mud grades into slightly sandy peaty mud which extends to $360 \mathrm{~cm}$. At this point, the slightly sandy peaty mud grades into sand which continues to the end of the core at $385 \mathrm{~cm}$. One buried peat sequence is recorded in this core. It is also possible that what appears to be a buried peat is a result of an ancient channel cut. These most upriver core sites are likely to be situated too far upstream from significant tidal influence to serve as reliable indicators of abrupt sea level changes on the order of $0.5-1 \mathrm{~m}$. 
TABLE VIII

SUMMARY OF COOS BAY C-14 DATES

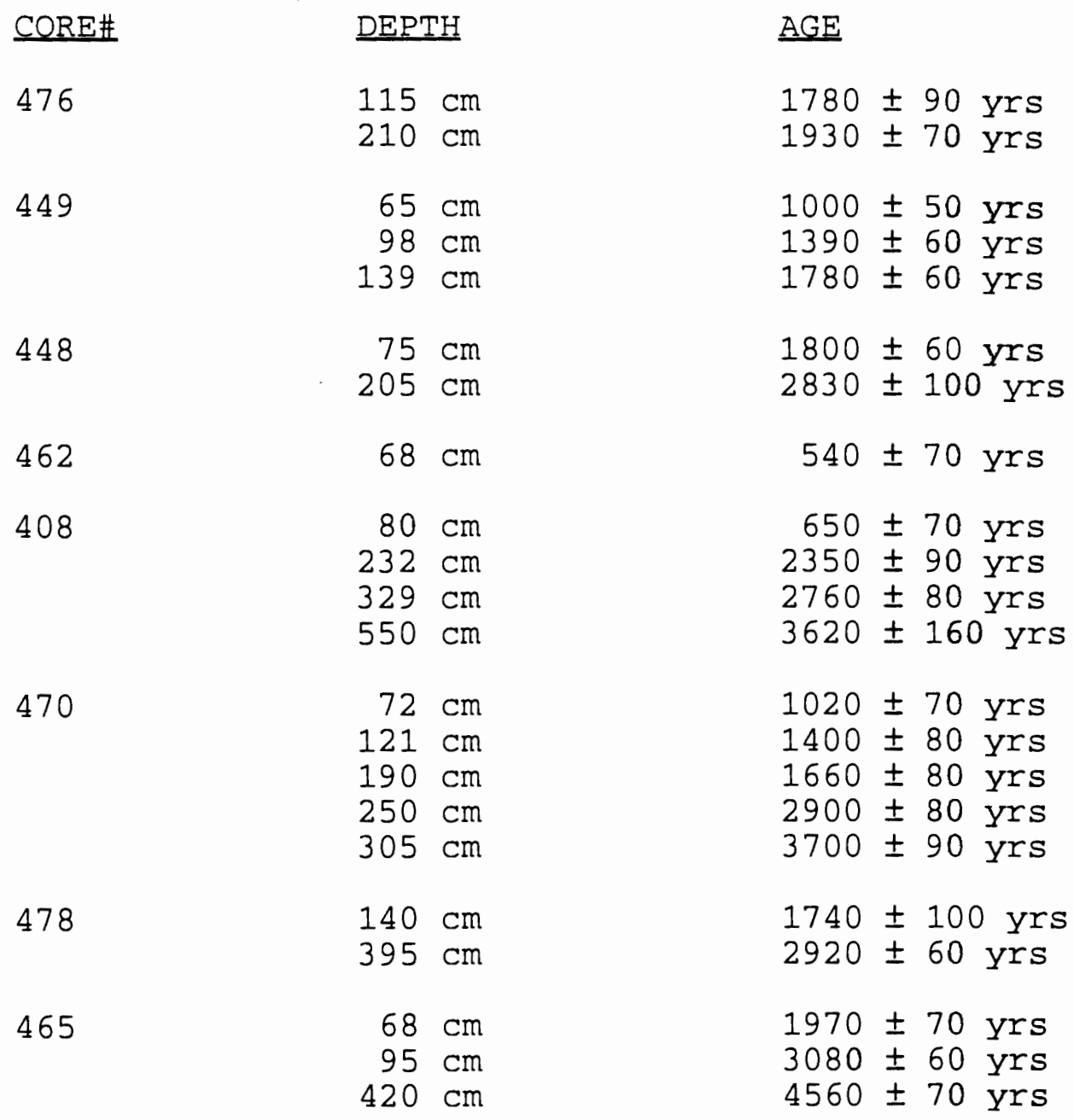


There are two general trends in the southern area of coos Bay. In the western portion, which includes sunset Bay, South Slough, and Pony slough, cores contain evidence of many episodic events. Cores from the central bay sloughs record few events. Progressing east from the central bay sloughs to eastern bay marshes, the number of events increases. Total sections recording peaty development generally extend back to 3000 RCYBP. Cores vary substantially in the number and ages of buried peaty sequences, ranging from one or no submergence events in 3000 years to as many as five or six submergence events in 3700 years in Pony slough site 470 . The cores taken in this area record a maximum range of five to six abruptly buried peats. This trend is interrupted by the core asymmetry seen within synclinal structures li.e. South Slough and Pony slough). The differences in the stratigraphy (continuous versus episodically buried peat) of cores taken in each of these synclinal basins suggest the presence of very active local structures. These active local structures appear to trend north northwest through the synclinal basins, based on the very limited core data.

\section{Diatoms}

Three cores taken from the coos Bay study area were analyzed for the presence of marine/brackish water marker 
diatoms. These are core 449 and core 450 at kentuck Slough and core 270 at Pony slough.

Core 449 Kentuck slough-This core was taken $10.2 \mathrm{~km}$ $(6.2 \mathrm{mi})$ due east of the ocean. It contains evidence of three buried peat sequences. Three samples taken from the core were analyzed for marker diatoms and were also radiocarbon dated. The remaining samples were analyzed for marker diatoms but were not dated (Table IX). The samples were taken down core from mud at $54 \mathrm{~cm}$, peat at $57 \mathrm{~cm}$ (this sample is dated at $1,000 \pm 50 \mathrm{RCYBP})$, mud at $83 \mathrm{~cm}$, peat at 88 cm (this sample was dated at 1,390 \pm 50 RCYBP), mud at 135 $\mathrm{cm}$, and peat at $139 \mathrm{~cm}$ (this sample dated at 1,780 \pm 60 RCYBP). With the exception of two peat samples, the other four samples all contain counts of marine/brackish water marker diatom assemblages large enough to predict a water salinity greater than $5 \%$. The two peat samples at $57 \mathrm{~cm}$ and $88 \mathrm{~cm}$ contain very low counts of marine/brackish water marker diatom assemblages suggesting that at the times represented by these peats, the water salinity on these supratidal marsh surfaces was $5 \%$ or less.

Core 450 Kentuck slough- This core is $300 \mathrm{~cm}$ long and is a continuous peat from the surface to a depth of $212 \mathrm{~cm}$. It was taken $1.7 \mathrm{~km}$ southwest of core 449 . This core was sampled for diatom analysis at the same depths as core 459 (Table IX). The marine/brackish water marker diatom 
TABLE IX

COOS BAY MARINE/BRACKISH JIATOM SAMPLING COUNTS \#I

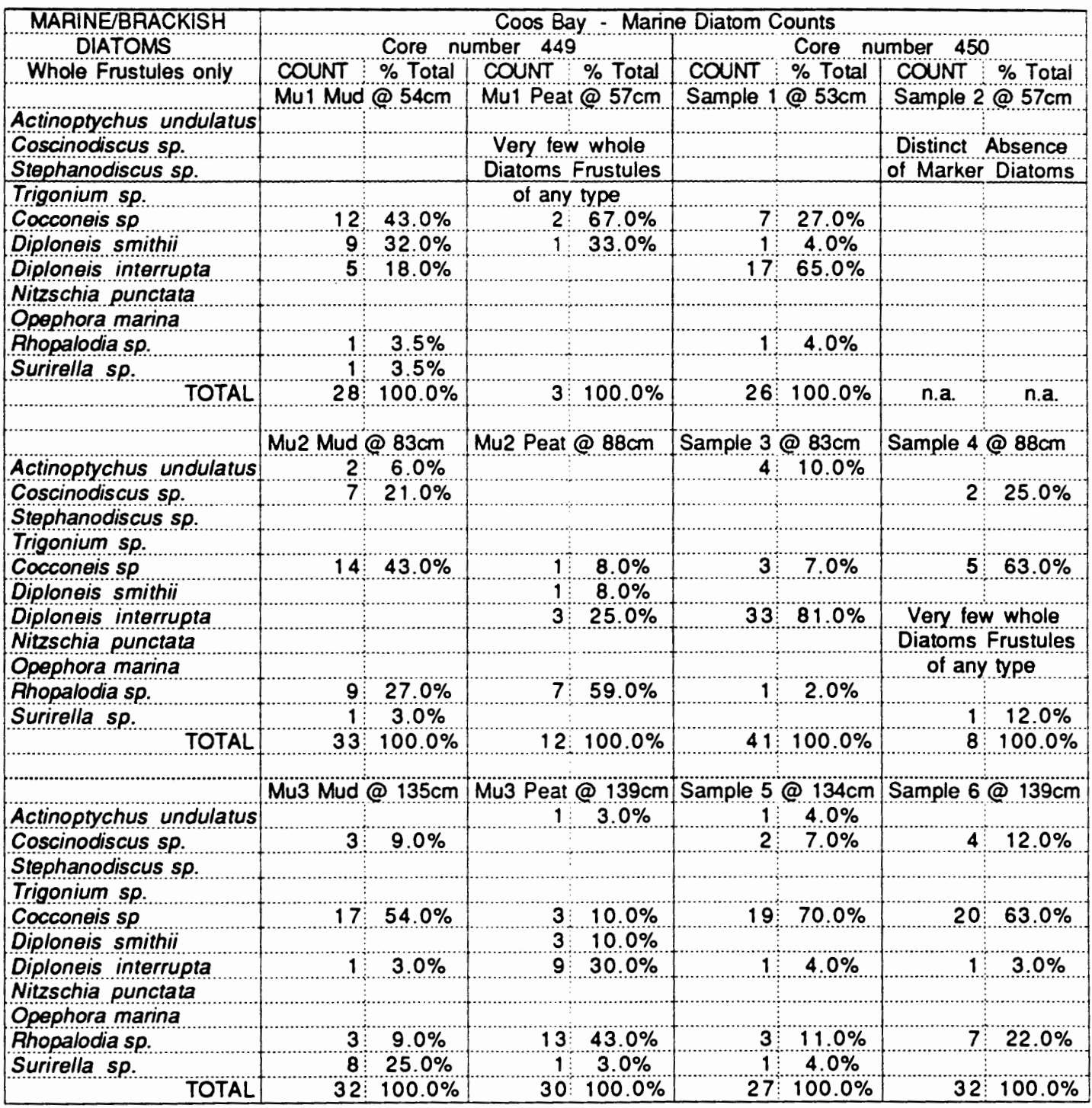


assemblage counts correlate with the counts seen in core 449 at the same depths. The samples taken at $57 \mathrm{~cm}$ and $88 \mathrm{~cm}$ contain very low counts of marine/brackish water marker diatom assemblages suggesting that at the times represented by these peat samples, water salinity on these wetland surfaces was $5 \%$ or less.

Core 470 Pony slough- This core was taken $6.5 \mathrm{~km}(4.0$ $\mathrm{mi})$ due east of the ocean. It is a core which records five marsh burial events. Five samples taken from the core were analyzed for marker diatoms and were also radiocarbon dated. The remaining five samples were analyzed for marker diatoms but were not dated (Table $\mathrm{x}$ ). The samples were taken down core from mud at $65 \mathrm{~cm}$, peat at $68 \mathrm{~cm}$ (this sample is dated at 1,020 \pm 70 RCYBP), mud at $110 \mathrm{~cm}$, peat at $115 \mathrm{~cm}$ (this sample is dated at $1,400 \pm 80$ RCYBP), mud at $175 \mathrm{~cm}$, peat at $185 \mathrm{~cm}$ (this sample is dated at 1,660 \pm 80 RCYBP), mud at 240 $\mathrm{cm}$, peat at $250 \mathrm{~cm}$ (this sample is dated at 2,900 \pm 80 RCYBP), mud at $295 \mathrm{~cm}$, and peat at 310 (this sample is dated at $3,700 \pm 90 \mathrm{RCYBP})$. The peat samples at $68 \mathrm{~cm}, 115 \mathrm{~cm}$, 185, $250 \mathrm{~cm}$, and $310 \mathrm{~cm}$ and the mud sample at $240 \mathrm{~cm}$ all contain low counts of marine/brackish water marker diatom assemblages. This core site has been influenced by tidal level throughout the last several thousand years. Although some marshes at this site may not have emerged sufficiently to evade some brackish water conditions between submergence events, the count of marker diatom assemblages is 
TABLE $X$

COOS BAY MARINE/BRACKISH DIATOM SAMPIING COUNTS \#2

\begin{tabular}{|c|c|c|c|c|}
\hline \multirow{2}{*}{\begin{tabular}{|c|} 
MARINEBBAACKISH \\
DIATOMS \\
\end{tabular}} & \multicolumn{4}{|c|}{ Coos Bay - Marine Diatom Counts } \\
\hline & \multicolumn{4}{|c|}{ Core number 470} \\
\hline \multirow{2}{*}{ Whole Frustules only } & COUNT & $\%$ Total & COUNT & $\%$ Total \\
\hline & \multicolumn{2}{|c|}{ Mut Mud @ $65 \mathrm{~cm}$} & \multicolumn{2}{|c|}{ Mut Peat @ $68 \mathrm{~cm}$} \\
\hline \multicolumn{5}{|l|}{ Actinoptyctius unoulalus } \\
\hline Coscinodiscus Sp. & 3 & $5.0 \%$ & 2 & $67.0 \%$ \\
\hline \multicolumn{5}{|l|}{ Siophanodiscus sp. } \\
\hline \multicolumn{5}{|l|}{ Trigonium sp. } \\
\hline Cocconess sp & 10 & $16.0 \%$ & 1 & $33.0 \%$ \\
\hline \multicolumn{5}{|l|}{ Dipioneis smithil } \\
\hline Diploneis intertupta & & & \multicolumn{2}{|c|}{ Almost Al Fresh Water } \\
\hline Nitzschia punctata & & & Diato & oms \\
\hline Opephora marina & 3 & $5.0 \%$ & & \\
\hline Ahopalodia sp. & $44 !$ & $71.0 \%$ & & \\
\hline Surirelia sp. & 2 & $3.0 \%$ & & \\
\hline (1) & 62 & $100.0 \%$ & 3 & $100.0 \%$ \\
\hline & & & & \\
\hline & Mu2 Mud & $110 \mathrm{~cm}$ & Mu2 Peat & $@ 115 \mathrm{~cm}$ \\
\hline Actinoptychus unoulatus & & & & \\
\hline Coscinodiscus sp. & 3 & $9.0 \%$ & & \\
\hline Stophanodiscus sp. & & & & \\
\hline Trigonium sp. & & & & \\
\hline Cocconois sp & 22 & $67.0 \%$ & 2 & $18.0 \%$ \\
\hline Diploneis smithii & & & & \\
\hline Oiploneis iniertupta & & & 2 & $18.0 \%$ \\
\hline Nitzschia punctata. & & & & \\
\hline Opephora manna & & & & \\
\hline Ahopalodia SP. & 5 & $15.0 \%$ & 2 & $18.0 \%$ \\
\hline surirella sp. & 3 & $9.0 \%$ & 5 & $46.0 \%$ \\
\hline (n) & 33 & $100.0 \%$ & 11 & $100.0 \%$ \\
\hline & & & & \\
\hline & Mu3 Mud & $175 \mathrm{~cm}$ & Mus Peat & $@ 185 \mathrm{~cm}$ \\
\hline Actinoptychus undulatus & & & & \\
\hline Coscinodiscus sp. & 5 & $24.0 \%$ & & \\
\hline stephanodiscus sp. & & & & \\
\hline Ingonium sp. & & & & \\
\hline Cocconess sp & 12 & $57.0 \%$ & Almost Ali $\vec{F}$ & resh Water \\
\hline Diploneis smithii & & & Diato & 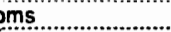 \\
\hline Diplonois interrupla & & & & \\
\hline Nitzschia punctata & & & & \\
\hline Opephora manna & & & & \\
\hline Ahopalodia sp. & 4 & $19.0 \%$ & & \\
\hline Surirella sp. & & & & \\
\hline TOTAL & 21 & $100.0 \%$ & na. & n.a. \\
\hline & & & & \\
\hline & Mus Mud & $240 \mathrm{~cm}$ & Mú Peat & $@ 250 \mathrm{~cm}$ \\
\hline Actinoplychus undulatus & & & & \\
\hline Coscinodiscus sp. & 1 & $8.0 \%$ & 2 & $13.0 \%$ \\
\hline Siophanodiscus sp & & & & \\
\hline Irigonium sp. & & & & \\
\hline Cocconoss.sp. & 10 & $84.0 \%$ & 3 & $20.0 \%$ \\
\hline Diplongis smithii & & & & \\
\hline Diploneis interrupta & 1 & $8.0 \%$ & 1 & $7.0 \%$ \\
\hline Nitzschia punctata & & & & \\
\hline Opophora manina & & & & \\
\hline Rhopalodia sp. & & & 6 & $40.0 \%$ \\
\hline Surirella sp. & & & 3 & $20.0 \%$ \\
\hline (1) & 12 & $100.0 \%$ & 15 & $100.0 \%$ \\
\hline & & & & \\
\hline & Mus Mud & $295 \mathrm{~cm}$ & Mus Peat & @ $310 \mathrm{~cm}$ \\
\hline Actinoptychus undulatus & & & & \\
\hline Coscinodiscus sp. & 7 & $35.0 \%$ & 2 & $50.0 \%$ \\
\hline Stephanodiscus Sp. & & & & \\
\hline Trigonium sp. & & & & \\
\hline Cocconois sp & 11 & $55.0 \%$ & 1 & $25.0 \%$ \\
\hline Diploneis smithii & & & & \\
\hline Oiploneis interupta & 1 & $5.0 \%$ & Almost All F & resh Water \\
\hline Nitzschia punctata & & & Diato & oms \\
\hline Opophora manina & 13 & $5.0 \%$ & & \\
\hline Rhopalodia sp. & & & & \\
\hline Suriretla sp. & & & 1 & $25.0 \%$ \\
\hline TOTAL & 20 & $100.0 \%$ & 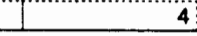 & $100.0 \%$ \\
\hline
\end{tabular}


sufficiently low to predict a water salinity on these marsh surfaces of $5 \%$ or less.

\section{DISCUSSION}

The identification of the landward extent of the zeroisobase in the central Cascadia subduction zone is the purpose of this thesis. The existence of a zero-isobase is based on the model characteristics of large megathrust earthquakes. The occurrence of an interplate earthquake on the Cascadia megathrust should result in uplift on the oceanward side of the zero-isobase zone and subsidence on the landward side of the zero-isobase zone (see inset diagram, figure 2). The zero-isobase is that area where no or very minimal vertical movement is observed with respect to elastic strain in the upper plate. The abruptly subsided wetlands, tidal marshes, and low lying forests landward of the zeroisobase are subsequently buried by bay sediments, following coseismic subsidence. The appearance of episodically buried peats is the primary evidence implying uplift and subsidence characteristic of great subduction zone earthquakes (Atwater, 1992). Peat layers which have sharp upper contacts with layers of tidal flat muds are a strong indication of the rapid burial of coastal lowland vegetation as a result of coseismic coastal subsidence (Peterson and Darienzo, 1992). The problem to be addressed here is whether buried peaty 
sequences in tidal marsh systems of the south-central Cascadia margin are produced by 1) elastic strain cycles landward of the zero-isobase, 2) local structure deformation associated with convergent margin compression or 3) nontectonic mechanisms of marsh flooding such as eustatic sea level fluctuations or local tidal creek dynamics. These competing mechanisms for episodic marsh submergence are addressed and discriminated in the following sections.

\section{Siuslaw Bay Area}

Progressing west to east in the Siuslaw River Basin the cores change in nature from continuous peats to episodically buried peats. Over the same progression (west to east) the incidence of sharp upper contacts markedly increases. These sharp upper contacts suggest sudden, rather than gradual subsidence. In the Siuslaw Bay study area, those cores taken in the area from the coastline due east to Deming Creek (where cores 207, 221, 222, and 223 appear in figure 17) approximately $6.5 \mathrm{~km}$ inland from the ocean, record nonepisodic buried wetlands. They are characterized by continuous peat or contain evidence of only one distinct buried wetland. Core 209 is the one exception to this observation. It contains two buried peat sequences which may be a result of flooding, channel submergence, or, more likely, channel migration. This core was taken at the outer 


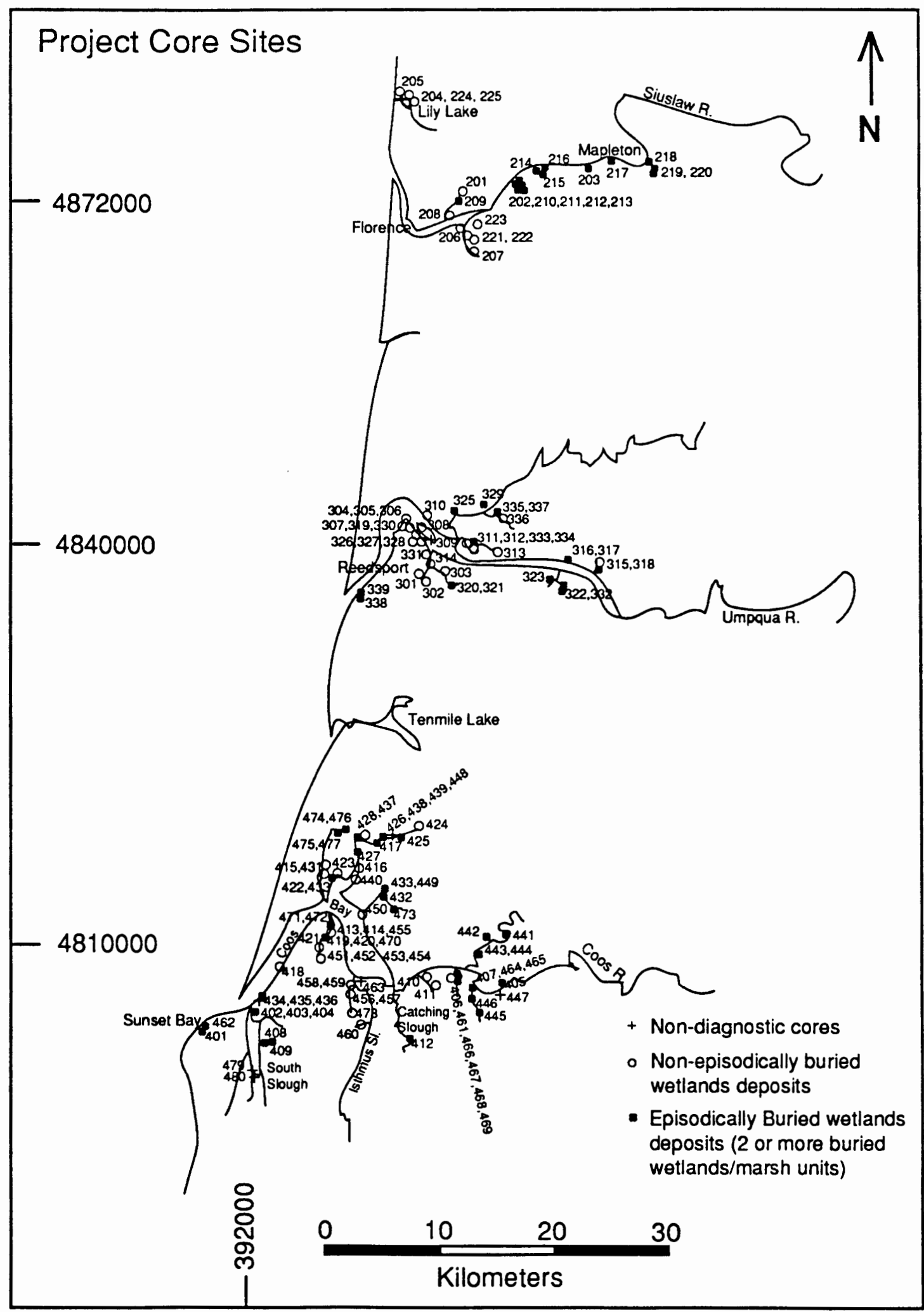

Figure 17. Composite core location map of coastal study area. 
edge of a migrating meander. Changes in river channel position could have affected the depositional record at this site.

Beginning at Bernhardt Creek (cores 202, 210, 211, 212, and 213) approximately $10 \mathrm{~km}$ due east of the ocean and continuing eastward to Hadsall Creek (cores 218, 219 and 220) $24 \mathrm{~km}$ due east of the ocean (figure 17) a different trend is observed. The cores from this area all record episodically buried peat sequences.

In addition to the record of buried peat sequences in the upper bay reaches, some anomalous sand layers in peaty sequences of the lower bay reaches might provide evidence of past megathrust events which produced tsunamis. Cores 221, 223, and 208 which were taken at Deming creek or slightly west of Deming Creek all contain anomalous thin sand layers, with sharp contacts within peaty (developed marsh) intervals. The cores from this area contain non-episodic buried wetlands and are characterized by continuous peat or contain evidence of one buried wetland. The sand layer in core 221 occurs at a depth of $365 \mathrm{~cm}$. Core 223 records a sand layer at a depth of $275 \mathrm{~cm}$. The sand layer in core 208 is seen at a depth of $350 \mathrm{~cm}$. Core 209 was also taken from this area, but it contains no evidence of a sand layer. At Bernhardt Creek, where cores do show episodic subsidence, Cores 213 and 216 contain thin sand layers, but the sand layers do not necessarily coincide with the most preeminent buried peats. 
All cores eastward of Bernhardt Creek lack any evidence of anomalous sand lenses. The presence of these thin sand layers within or above buried peats together with distance landward is characteristic of tsunami inundation in other Cascadia subduction zone bays (Darienzo, 1991). The origin of these anomalous sandy layers in the lower reaches of Siuslaw Bay warrant further study as they might provide further evidence of possible coseismic subsidence.

The presence of a flame-like injection feature observed in core 213 is indicative of liquefaction. Liquefaction of saturated sediments can be initiated by strong ground motions (shaking) and might provide additional evidence seismic activity in late Holocene time.

Radiocarbon dating of selected buried peat sequences from cores taken in the siuslaw Bay study area allow for the calculation of an average recurrence interval between successive subsidence events. The Siuslaw Karnowsky core 216 records at least four distinct events and possibly five, between $540 \pm 70$ (probable 650 yr BP South Slough event suggested by Darienzo, abstract, 1989 or possibly the $300 \mathrm{yr}$ BP event suggested by Atwater, 1987 and Darienzo, 1991) and $1910 \pm 70$ RCYBP. Based on these dates the average recurrence interval for these events is approximately 540 years, assuming four events and 400 years, assuming five events.

The analysis of diatom assemblages observed in core samples can provide some information useful in explaining 
paleo-tidal environments. However, this usefulness is limited by seasonal and other environmental variables. Seasonal variations occur in solar radiation, rainfall, and salinity (exposure to marine/brackish tidal flow in the summer and exposure to fresh water in the winter). Also, a greater salinity range occurs in the summer. These environmental variables are known to affect the distribution of diatoms seasonally and interannually. (Moore and McIntire, 1977). For example, Main and McIntire (1974) noted wintertime differences in assemblages of host-epiphyte diatoms (organisms attached to the surface of a plant). The abundance of pennate diatom assemblages were also observed to vary seasonally and from year to year. Pennate diatoms were reportedly dislodged from benthos during winter runoff, affecting seasonal counts in Yaquina Bay (Karentz and McIntire, 1977). Furthermore, differences in the structure of diatom assemblages within local areas are also attributed to properties of sediment, such as, mean sediment size and percentage of organic carbon (Moore and McIntire, 1976).

The salinity, desiccation gradients, and seasonal changes in solar radiation are the primary controlling factors affecting distribution of diatoms. Mean salinity accounts for the most variability between samples (Moore and McIntire, 1977). However, distributions of diatoms (in time and space) overlap along the salinity gradient from a marine environment to a brackish water environment to the point 
where the salinity is $5 \%$. Below this salinity level freshwater diatoms dominate (Moore and McIntire, 1977).

Janet Cruden, a researcher at Portland State University, has studied the diatoms of Pacific Northwest estuaries for many years. She has revisited coastal sites annually for a numbers of years and has noted a wide range of variation in diatom species counts and species dominance from year to year. She attributes these variations to changes in climatic and oceanic conditions such as those produced by El Ninos (personal communication, unpublished data, 1994).

The counts of marine/brackish water diatoms in this study reflect very conservative numbers for several reasons. Only whole frustules were counted. However, samples contained numerous portions of broken frustules which were not counted. The number of diatoms represented by these broken pieces could substantially increase the count. The assemblage of marine/brackish water marker diatoms was necessarily limited due to the very large number of marine species and did not include all species subsequently observed after the initial selection of the marker assemblage (see Methods).

Analysis of diatoms can be useful in helping identify supratidal environments in lower bay reaches where salinity is less than $5 \%$ (few or no marine/brackish water diatoms) and in tidally influenced marshes where many marine/brackish water diatoms are present. The presence of marine/brackish 
water diatoms is a key tidal elevation indicator. The absence of marine/brackish water diatoms in lower bay reaches could imply local marsh emergence above the reach of high tides (this only works if underlying muds contain abundant marine/brackish water diatoms). However, further resolution of intertidal zonation by diatoms is not considered to be reliable by this author.

Three cores taken from the Siuslaw Bay study area were analyzed for the presence of whole frustule marine/brackish water marker diatoms (TABLE V). These are core 216 at the mouth of Karnowsky Creek, core 222 at Deming Creek, and core 225 at Lily Lake.

There appears to be no distinct variations of count totals for marine/brackish water diatoms between the mud and peaty units of core 216 (TABLE XI), with the possible exception of the sample taken at a depth of $144 \mathrm{~cm}$. This sample shows the presence of solely fresh water diatoms. The other samples from this core contain assemblage counts of 43 to 103 marker diatoms, indicating that this site was substantialiy influenced by tidal flow and tidal elevation through its period of record (2000 years). The lack of peaty samples showing an absence of marine/brackish water diatoms shows that marsh emergence (between submergence events) never reached supratidal elevations, except for the sample taken at a depth of $144 \mathrm{~cm}$. 
TABLE XI

SIUSLAW MARINE/BRACKISH (M/B) DIATOM ASSEMBLAGE SUMMARY OF CORE 216

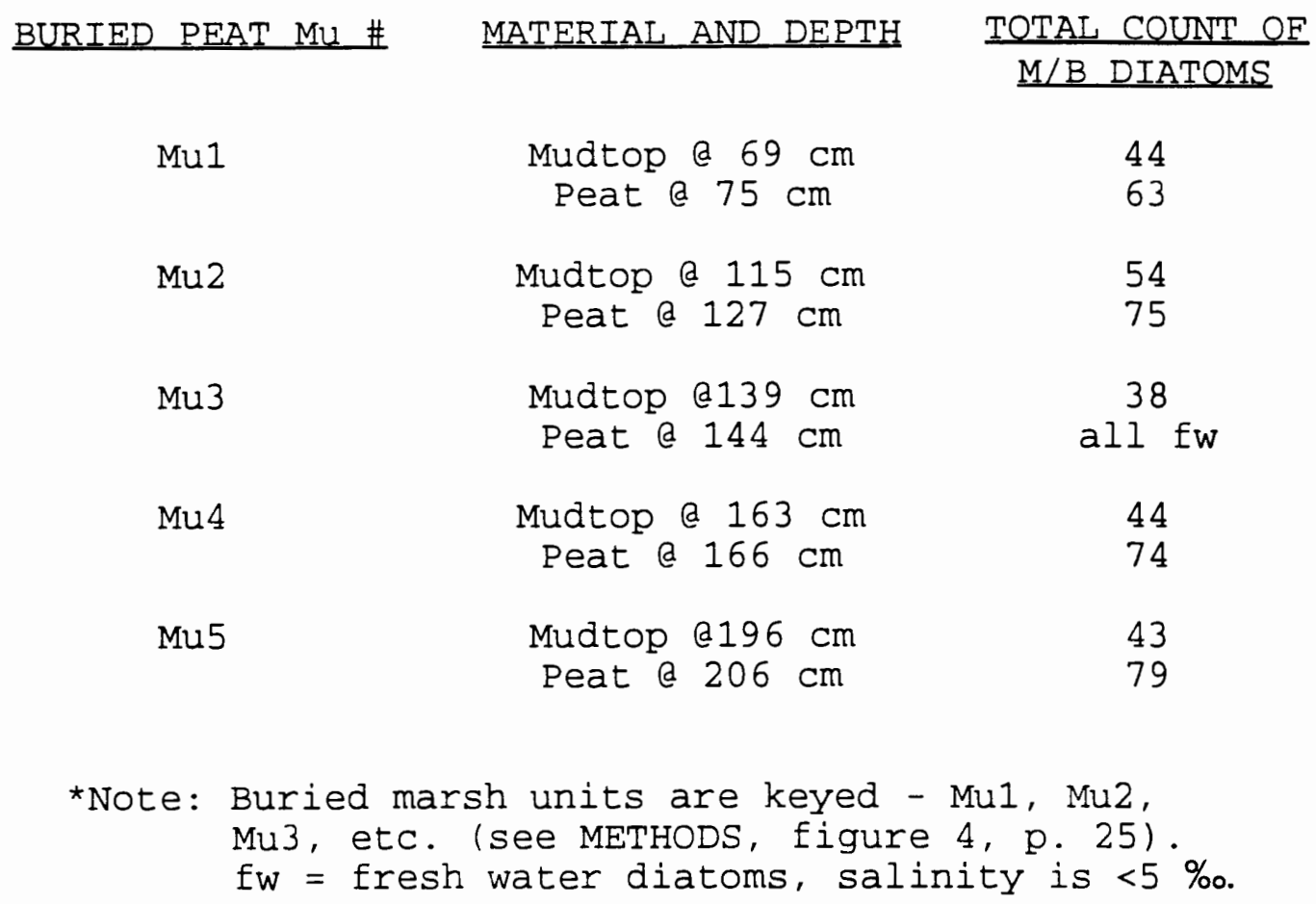

In the first $115 \mathrm{~cm}$ of core 222, three samples were taken which show the complete absence of all marine/brackish water marker diatoms. The seven samples taken between $115 \mathrm{~cm}$ and $206 \mathrm{~cm}$ contain small numbers of marine/brackish water marker diatoms. These small counts suggest an environment of ocean water of varying low salinity and accompanying plant 
species variation. The complete lack of distinct marine/brackish marker diatoms above the depth of $115 \mathrm{~cm}$ may be because the marsh emerged above the reach of high tides. Apparently there were no submergence events at this site that were capable of lowering the marsh to intertidal elevations. According to local residents, this area has been cut off from tidal influence by a tidal gate for the past forty years, so the modern wetland conditions do not accurately represent prehistoric tidal influence at this site.

Samples for diatom analysis taken from core 225 (Lily Lake) at varying depths show a complete lack of marine/brackish water marker diatoms, suggesting that the lake has been cut off from the ocean for at least 3,000 years (basal core date of $3030 \pm 70$ RCYBP).

of the three cores from this area sampled for diatoms, the diatom data from core 216 are the most useful. This information helps explain the paleo-tidal environment of Mu 3 and it indicates the possible degree of subsidence associated with this burial event.

This author has interpreted the area of transition between continuous peaty sections at Deming Creek and episodically subsided sections at Bernhardt Creek (approximately $105 \mathrm{~km}$ due east of the trench) as the landward extent of the zero-isobase in the siuslaw Bay area. 
Lower Umpqua River Area

In the Umpqua River study area a similar pattern of change, west to east, from continuous peaty cores to episodically buried peat, cores is seen (figure 17). At the western most extent of the study area, cores 339 and 338 at Winchester Bay do not fit this pattern (core group 1, TABLE XII). They contain episodically buried peats and are characterized by sharp upper and sharp lower contacts. These sharp lower contacts are consistent with uplift indicative of the oceanward extent of the zero-isobase or local structure deformation. Discrimination between these two uplift mechanisms is not possible in the umpqua study area. Eastward from cores 339 and 338 to $11 \mathrm{~km}$ due east of the ocean, cores are consistently non-episodic in their nature of peat or rooted mud deposition (core group 2, TABLE XII). The area between 11 and $14 \mathrm{~km}$ due east of the ocean is a transition zone which yielded some cores containing nonepisodically buried peats and others which contain episodically buried peats (core group 3, TABLE XII). From Dean Creek $16.5 \mathrm{~km}$ due east of the ocean and progressing eastward to Harvey Creek $21 \mathrm{~km}$ due east of the ocean the cores, with the exception of core 318 , record $3-4$ episodically buried peat sequences (core group 4, TABLE XII). 


\section{TABLE XII}

UMPQUA (WEST TO EAST)

CORE TRANSITIONAL GROUPS

\begin{tabular}{ccccccc} 
GROUP 1 CORES & GROUP 2 CORES & GROUP 3 CORES & GROUP 4 CORES \\
\cline { 2 - 5 } 338,339 & $301,302,303$ & $311,312,313$ & $315,316,317$ \\
& $304,305,306$ & $320,321,325$ & $318,322,323$ \\
& $307,308,309$ & $329,333,334$ & 332 \\
& $310,314,319$ & $335,336,337$ & \\
& $326,327,328$ & & & \\
& 330,331 & &
\end{tabular}

Progressing east from Oar Creek, where cores 320 and 321 were taken, the incidence of sharp upper peat contacts increases. This is a distinctive characteristic of rapid marsh/wetland burial episodes indicating abrupt subsidence. Anomalous sand layers are apparent in many of the cores from the Umpqua Bay area (TABLE XIII). Thirty-eight cores were taken in this area. Fourteen of these cores contain anomalous sand layers which are candidate tsunami layers. These sand layers overlay buried peats and generally become thinner with increasing distance landward suggesting tsunami inundation. 


\title{
TABIE XIII
}

\author{
UMPQUA AREA CANDIDATE TSUNAMI LAYERS \\ (ANOMALOUS SAND LAYERS ABOVE OR WITHIN BURIED PEATS) \\ LISTED WEST TO EAST
}

\begin{tabular}{|c|c|c|}
\hline CORE NUMBER & LOCATION & DEPTH TO LAYERS \\
\hline 338 & Winchester Bay & 178 and $300 \mathrm{~cm}$ \\
\hline 339 & Winchester Bay & 86,170 and $270 \mathrm{~cm}$ \\
\hline 304 & The cut off & $75 \mathrm{~cm}$ \\
\hline 306 & The cut off & $76 \mathrm{~cm}$ \\
\hline 330 & The cut off & $80 \mathrm{~cm}$ \\
\hline 308 & Steamboat Island & $60 \mathrm{~cm}$ \\
\hline 310 & Gardiner Paper Mill & $75 \mathrm{~cm}$ \\
\hline 331 & $\begin{array}{l}\text { Scholfield Creek } \\
\text { Mouth }\end{array}$ & $65 \mathrm{~cm}$ \\
\hline 303 & Scholfield creek & $65 \mathrm{~cm}$ \\
\hline 301 & Scholfield creek & $186 \mathrm{~cm}$ \\
\hline 311 & Butler Creek & $79 \mathrm{~cm}$ \\
\hline 333 & Butler Creek & $30 \mathrm{~cm}$ \\
\hline 316 & Harvey Creek & 173 and $290 \mathrm{~cm}$ \\
\hline 317 & Harvey Creek & $175 \mathrm{~cm}$ \\
\hline
\end{tabular}


Radiocarbon dating of core 301 and AMS dating of core 311 yielded dates of $400 \pm 60$ RCYBP and $310 \pm 50$ RCYBP, respectively (probable 300 year BP event suggested by Atwater, 1987 and Darienzo, 1991). This probable 300 year event is not seen in the other dated cores. Where the event is evident, it is a subtle event as reflected in the slight degree of change in peat stratigraphy. The subtle recording of this event may explain why it is not apparent in the other dated cores. The event may not have been recorded or may have been so subtle that it is not recognizable in other cores to the west. Based on the event (probable 300 year event) recorded in cores 311 and $301(400 \pm 60$ RCYBP and 310 \pm 50 RCYBP, respectively) and the three dated events in core 339 (oldest date is $1850 \pm 60$ RCYBP), an average recurrence interval is estimated to be 520 years.

Two cores ( 332 and 328 ) from the Umpqua River area were analyzed for the presence of marine/brackish water marker diatoms (TABLE VI). Analysis of core 332 revealed a distinct absence of marine/brackish water diatoms throughout the core (TABLE XIV). The absence of marine diatoms suggests the salinity level is below $5 \%$. This is reasonable to expect given the distance upstream where fresh water predominates the in the estuary. 
TABLE XIV

UMPQUA MARINE/BRACKISH (M/B) DIATOM ASSEMBLAGE

SUMMARY OF CORE 332

\begin{tabular}{|c|c|c|}
\hline BURIED PEAT MU \# & MATERIAL AND DEPTH & $\frac{\text { TOTAL COUNT OF }}{\mathrm{M} / \mathrm{B} \text { DIATOMS }}$ \\
\hline Mu1 & $\begin{array}{l}\text { Mudtop \& } 54 \mathrm{~cm} \\
\text { Peat a } 76 \mathrm{~cm}\end{array}$ & $\underset{2}{\operatorname{mostly}} \mathrm{fw}$ \\
\hline Mu2 & $\begin{array}{l}\text { Mudtop } @ 113 \mathrm{~cm} \\
\text { Peat a } 125 \mathrm{~cm}\end{array}$ & $\begin{array}{ll}\operatorname{all} & \mathrm{fw} \\
\mathrm{a} 11 & \mathrm{fw}\end{array}$ \\
\hline Mu3 & $\begin{array}{l}\text { Mudtop } 9168 \mathrm{~cm} \\
\text { Peat a } 180 \mathrm{~cm}\end{array}$ & $\begin{array}{ll}\operatorname{all} & \mathrm{fw}_{\mathrm{w}} \\
\text { all } & \mathrm{fw}\end{array}$ \\
\hline
\end{tabular}

*Note: Buried marsh units are keyed - Mu1, Mu2, Mu3, etc. (see METHODS, figure 4, p. 25).

$\mathrm{fw}=$ fresh water diatoms, salinity is $<5 \%$.

Core 328 contains marine/brackish water diatoms at all sample depths. The six samples from this continuous peaty core contain counts of 17 to 110 diatoms. The variations in marker diatom counts could be attributed to environmental factors as addressed in the discussion of the Siuslaw Bay area. Alternatively, these counts could indicate variations between high and low tidal elevations. However, the diatom results substantiate the fossil organic matter interpretations that marsh elevations at this site remained at intertidal levels throughout the period of record 10 2500 RCYBP) . 
The information gained from diatom analysis of core 332 identifies the paleo-tidal environment of the core site as predominately freshwater. The diatom analysis of core 328 suggests a paleo-tidal environment of marine/brackish water with a salinity greater than $5 \%$.

The area of transition from primarily continuous peat to episodically buried wetlands observed in the Umpqua Bay study area is interpreted by this author as the landward extent of the zero-isobase. This area is $14 \mathrm{~km}$ due east of the ocean, just east of group 3 cores (TABLE XII), and $114 \mathrm{~km}$ due east of the trench.

\section{Coos Bay Area}

In the northern part of the coos Bay area the number of buried peats and the depth of burial increases with distance eastward. This change is seen along the eastern edge of coos Bay where Palouse Creek flows into Haynes inlet and Kentuck Creek flows into Kentuck inlet (figure 17). If a line were drawn along this zone of transition it would meet the fault line at Catching Slough first mapped by Allen and Baldwin (1944) and later by others. It is possible that the presence of a local structure in the northern portion of coos Bay may have affected the transition in stratigraphy observed in this area. Those cores east of the hypothetical line mentioned above are also within this zone of transition. 
Bcth continuous peat and episodically buried peat cores are seen here; however, the trend is toward predominately episodically buried peats with increasing distance eastward. The maximum number of buried peats seen in the northern area is four. The number of buried peats and the depth of burial increases eastward. The incidence of sharp upper contacts also increases suggesting sudden rather than gradual subsidence. The transitional nature of the northern area where a mix of both continuous peat and episodically buried peat cores is evident suggests that the landward extent of the zero-isobase is east of these cores.

Based on northern coos Bay core 449 taken at Kentuck Creek which records three distinct burial events between 1000 \pm 50 RCYBP and $1780 \pm 60$ RCYBP and on core 448 taken from Palouse Creek which records four distinct burial events between $1800 \pm 60$ RCYBP and $2830 \pm 100$ RCYBP, the average recurrence interval between successive subsidence events is approximately 366 years. Events younger than about 1000 RCYBP in core 449 and 1800 RCYBP in core 448 are not recorded at these sites. There are several possible explanations for the absence of a record of these younger events: 1) artificial effects from diking, draining, and pasturing may have altered the uppermost marsh stratigraphy at these sites, 2) these sites represent valley side marshes (high marshes) where subtle subsidence events were not recorded as they would have been in low marsh settings, 3) long cores from all 
of these slough inlets shows them to have evolved from tidal flat to low marsh to high marsh environments during the latest Holocene period of minimum eustatic sea level rise resulting in the absence of the most sensitive low marsh settings.

In the southern area of Coos Bay (figure 17) the progression from continuous peat cores to episodically buried peat cores, as observed in the Siuslaw Bay and Umpqua Bay study areas, is complicated by the presence of local synclinal structures which isolate marsh systems.

Cores 401 and 462 were taken at the westernmost edge of the study area (Sunset Bay) less than one kilometer from the ocean. Evidence of continuous peat would be expected here, yet the cores contain evidence of at least nine buried peat/detrital sequences since $3510 \pm 80$ RCYBP. Based on nine events over a period of 3210 years seen in core 462 , the average recurrence interval is 390 years. There is a known fault structure at Sunset Bay which was first inferred by Allen and Baldwin (1944) and later mapped by Baldwin (1966). Its presence raises a question as to the cause of these burial events. Unfortunately, the extremely limited spatial distribution of marsh wetland sites in this area precludes a further analysis of wetland development and/or tectonic response on either side of the mapped fault.

Four cores were taken at South Slough, east of Sunset Bay. Two cores (479 and 480) were taken on the west side of 
South Slough and are non-diagnostic, containing no evidence of marsh burial events. The other two cores (409 and 408) were taken on the east side of the slough and record five to six buried marsh sequences. Other cores taken by Peterson and Darienzo on Talbot Creek at the southeast end of South Slough also contain evidence of multiple buried peats (GSA Abstract, 1989). A direct comparison of cores 479 and 480 with cores 408, 409, and Peterson and Darienzo's cores from Talbot Creek cannot be made due to the lack of intertidal marsh records at the western slough sites. However, the lack of episodic marsh development is suggestive of some depositional or tectonic asymmetry in the slough. The relationship of these cores to each other may infer the presence of a local fault structure running north northwest within this synclinal basin. This area of the South Slough syncline is presently the subject of ongoing fault research by I. Madin (pers. comm., 1994) (figure 18). The six events between $650 \pm 70$ RCYBP and $3620 \pm 160$ RCYBP (Peterson and Darienzo, 1989) seen in core 408, suggest an average recurrence interval of 594 years.

Three cores $(402,403$, and 404) taken at Bar View contain evidence of three episodically buried peats. They were taken north of the eastern side of the South Slough synclinal basin. Their episodic nature is consistent with the cores from the east side of South Slough. Three short cores $(434,435$, and 436) showed evidence of one burial 


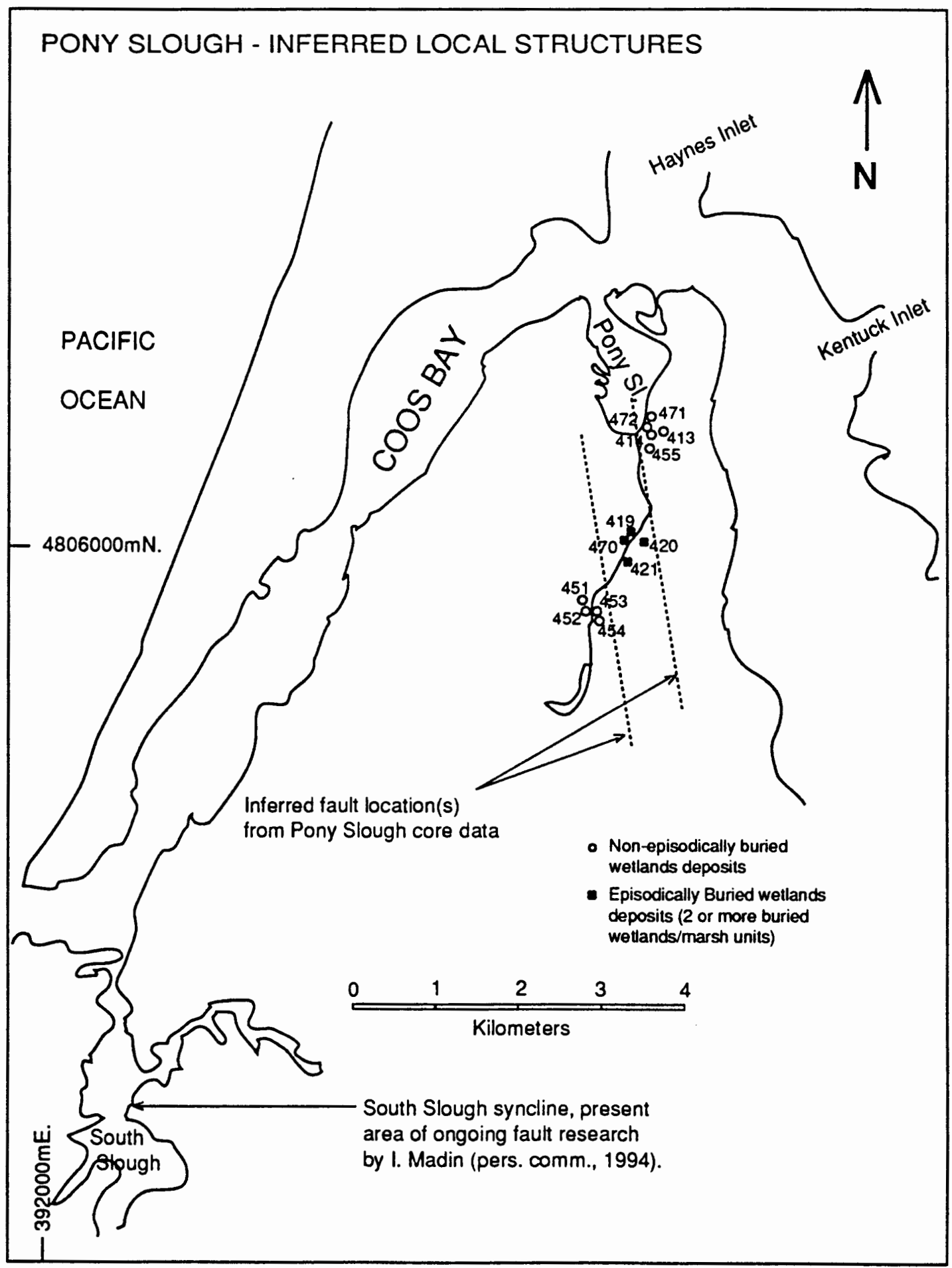

Figure 18. Inferred faults within the Pony Slough synclinal basin. The difference in stratigraphy (continuous versus episodically buried peats) and number of burial events in the last $3000 \mathrm{bp}$. suggest the presence of very active local structures. 
event. The marsh from which these cores were taken has been significantly altered by diking and dredge spoil dumping. The youngest horizons in the core tops might be disturbed or even the result of artificial disturbance in this locality.

Within the Pony Slough area (figure 18), $7 \mathrm{~km}$ due east of the ocean, the cluster of cores 470,419, 420, and 421 all contain evidence of episodically buried peats. One kilometer to the southwest of this cluster is the group of cores 451 , 452, 453, and 454. This group shows no evidence of episodically buried peats. The group of cores 413, 414, and 455 which is north and slightly east of the cluster also contain no evidence of episodic peat burial. The relationship of these cores to each other infers the presence of very active local blind fault structures running north northwest through the Pony Slough area (see figure 18). Subsidence is distinctly recorded in the center cluster of cores, but not on those cores outside this cluster. Based on five events between $1020 \pm 70$ RCYBP and $3700 \pm 90$ RCYBP seen in core 470, the average recurrence interval is 670 years. This core also contains an oxidized zone at a depth of $43 \mathrm{~cm}$. This oxidized zone may represent the 300 year event addressed in the discussion of the Siuslaw and Umpqua areas, or it may have a non-tectonic origin. Additional study of this locality is needed to establish the origin of this buried oxidized zone. 
The origin(s) of the episodically buried peaty sequences observed in Sunset Bay, South Slough, and Pony Slough, where transverse structures are reported to be present, is an interesting question. They could be the result of 1) random, independent local tectonic events, 2) a consequence of the activity of local structures concurrent with a megathrust release, or 3) a result of the growth of local structures activated by and occurring subsequent to a megathrust earthquake.

There is no historic record of seismic events in these upper plate structures in the Siuslaw Bay, Umpqua River and Coos Bay study areas during the last 200 years, at least according to white European settlers. If the buried peat sequences are the result of independent local tectonic events there should be evidence of random seismic activity occurring in this area during the last 200 years. According to Goldfinger (1992), "Given the evidence for late Pleistocene to Holocene activity on these faults and folds, and the evidence for large Cascadia earthquakes, their present quiescence circumstantially supports their role as structures secondary to the megathrust". Analyses of Geodolite surveys in the seattle area, combined with triangulation surveys in the Straits of Juan de Fuca, and numerous leveling surveys along the Pacific Northwest coast, have demonstrated evidence of accumulating elastic strain in the cascadia subduction zone (Savage and Lisowski, 1981). The historic record of low 
seismic activity under conditions of accumulating elastic strain further suggests that the activity of local structures is linked to megathrust releases.

A comparison of the radiocarbon dates across the study area reveals a number of burial events which appear to cluster at roughly similar time intervals (TABLE XV). For example, one cluster of peat dates is centered about 500 RCYBP, another about 1000 RCYBP, another at about 1400 RCYBP, and another at about 1900 RCYBP. If, as suggested, these local faults and folds are triggered by megathrust releases, the burial events associated with these local structures occurred simultaneously with the releases or shortly thereafter.

The results from radiocarbon dating and the lack of active seismicity under the condition of elastic strain accumulation imply that the burial events recorded within Sunset Bay, South Slough, and Pony Slough strongly suggest that they are associated with megathrust releases. Additional work on candidate tsunami layers in these bays is needed to further test this hypothesis.

The area of Coalbank Slough $11.7 \mathrm{~km}$ due east of the ocean to Vogel Creek $17.5 \mathrm{~km}$ due east of the ocean in the southern coos Bay area yielded cores which are consistently non-episodic in their nature of peaty deposits. They are characterized by continuous peaty units or contain evidence of only one buried wetland surface. 
TABLE XV

COMPARATIVE RADIOCARBON DATES ACROSS THE STUDY AREA

SIUSLAW

UMPOUA

$310 \pm 50$

$400 \pm 60$

$540 \pm 70$

$1320 \pm 60$

$1450 \pm 70$

$1540 \pm 70$

$1630 \pm 60$

$1850 \pm 60$

$1910 \pm 70$

$3030 \pm 70$

$1420 \pm 80$

$2960 \pm 60$

$$
1040 \pm 60
$$

$3140 \pm 70$
$1000 \pm 50$

$1390 \pm 60$

$650 \pm 70$

$1020 \pm 70$

$1400 \pm 80$

$1660 \pm 80$

$1780 \pm 90$

$1780 \pm 60$

$1930 \pm 70$

S. COOS BAY

$1740 \pm 100$

$1970 \pm 70$

$2830 \pm 100$

$2900 \pm 80$

$3080 \pm 60$ 
At the Smith Ranch, $20 \mathrm{~km}$ due east of the ocean, a transition is made from non-episodic peat to episodically buried peat sequences. East of Smith Ranch and progressing inland along the coos River to a point $23.9 \mathrm{~km}$ due east of the ocean all of the cores contain episodically buried peat sequences .

Eleven cores taken from the coos Bay study area contain evidence of anomalous sand layers which are candidate tsunami layers (TABLE XVI). These sand layers overlay or are contained within buried peats or detrital material and they generally become thinner with increasing distance landward suggesting tsunami inundation.

The recurrence intervals calculated from radiocarbon dating of peat samples from cores 449,448,462, 408, and 470 range from 366 years to 670 years (TABLE XVII).

Three cores taken from the coos Bay study area were analyzed for the presence of whole frustule marine/brackish water marker diatoms (TABLE IX, and TABLE X,). These are cores 449 and 450 at Kentuck Slough and core 470 at Pony Slough. Among the diatom assemblages seen in the samples taken from core 449, there are distinct variations in the counts of marine/brackish water marker diatoms (TABLE XVIII). Analysis of the sample from the peat of Mul (the uppermost buried marsh/forest unit) showed an almost complete absence of marine/brackish water marker diatoms indicating 
TABLE XVI

COOS BAY AREA CANDIDATE TSUNAMI LAYERS

(ANOMALOUS SAND LAYERS ABOVE BURIED PEATS)

$\begin{array}{ccc}\text { CORE NUMBER } & \text { LOCATION } & \text { DEPTH TO LAYERS } \\ 475 & \text { Hauser Slough } & 192 \mathrm{~cm} \\ 417 & \text { Palouse Slough } & 115 \mathrm{~cm} \\ 462 & \text { Sunset Bay } & 355 \text { and } 505 \mathrm{~cm} \\ 408 & \text { South Slough } & 223 \mathrm{~cm} \\ 409 & \text { South Slough } & 158 \mathrm{~cm} \\ 402 & \text { Bar View Area } & 125 \text { and } 225 \mathrm{~cm} \\ 471 & \text { Pony Slough } & 233 \mathrm{~cm} \\ 472 & \text { Pony Slough } & 197 \mathrm{~cm} \\ 470 & \text { Pony Slough } & 245 \mathrm{~cm} \\ 466 & \text { Smith Ranch } & 154 \text { and } 223 \mathrm{~cm} \\ 467 & \text { Smith Ranch } & 149 \mathrm{~cm} \\ 469 & \text { Smith Ranch } & 175 \mathrm{~cm}\end{array}$

TABLE XVII

COOS BAY RECURRENCE INTERVALS (R.I.)

$\begin{array}{ccc}\text { CORE NUMBER } & \text { NUMBER OF EVENTS } & \underline{\text { R.I. }} \\ 448,449 & 6 & 366 \text { yrs } \\ 462 & 9 & 390 \text { yrs } \\ 408 & 6 & 594 \text { yrs } \\ 470 & 5 & 670 \text { yrs }\end{array}$


TABLE XVIII

NORTHERN COOS BAY AREA MARINE/BRACKISH (M/B)

DIATOM ASSEMBLAGE

SUMMARY OF CORE 449

\begin{tabular}{|c|c|c|}
\hline BURIED PEAT MU \# & MATERIAL AND DEPTH & $\begin{array}{l}\text { OTAL COUNT OF } \\
\text { M/B DIATOMS }\end{array}$ \\
\hline Mu1 & $\begin{array}{l}\text { Mudtop@ @ } 54 \mathrm{~cm} \\
\text { Peat @ } 57 \mathrm{~cm}\end{array}$ & $\begin{array}{c}28 \\
3\end{array}$ \\
\hline Mu2 & $\begin{array}{l}\text { Mudtop @ } 83 \mathrm{~cm} \\
\text { Peat @ } 88 \mathrm{~cm}\end{array}$ & $\begin{array}{l}33 \\
12\end{array}$ \\
\hline Mu3 & $\begin{array}{l}\text { Mudtop \& } 135 \mathrm{~cm} \\
\text { Peat \& } 139 \mathrm{~cm}\end{array}$ & $\begin{array}{l}32 \\
33\end{array}$ \\
\hline SUMMARY OF & CORE 450 (CONTINUOUS PEAT & CORE) \\
\hline
\end{tabular}

CONTINUOUS PEAT SAMPLES NUMBER

$\frac{1}{2}$

3

5

6
MATERIAL AND DEPTH

Peat \& $53 \mathrm{~cm}$

Peat a $57 \mathrm{~cm}$

Peat a $83 \mathrm{~cm}$

Peat \& $88 \mathrm{~cm}$

Peat a $134 \mathrm{~cm}$

Peat @ $139 \mathrm{~cm}$
TOTAL COUNT OF M/B DIATOMS

\author{
26 \\ mostly EW
}

41

8

27

32

* Note: Buried marsh units are keyed - Mu1, Mu2, Mu3, etc. (see METHODS, figure 4, p. 25) $\mathrm{fw}=$ fresh water diatoms, salinity is $<5 \%$. 
that at the time represented by this peat sample, the water salinity was $5 \%$ or less. This low salinity suggests a supratidal environment. The sample from the mud (Mul) immediately above this peat showed a relatively high number of marker diatoms. For a supratidal marsh or forest surface to be buried by bay mud sediments there must be a minimum of 1 to $2 \mathrm{~m}$ of vertical drop (subsidence). The diatoms here support a submergence origin for the burial of this peat by bay muds.

The peat sample from Mu2 contained a low number of marker diatoms. The sample from the mud above this peat contained nearly three times as many marker diatoms. Like Mu1, the diatom data from Mu2 also suggests significant vertical displacement. In this case the fossil organics indicate a drop of $0.5 \mathrm{~m}$ to $1.5 \mathrm{~m}$ from a high tidal environment to a barren tidal flat. A high count of marker diatoms is seen in both the peat and mud of Mu3. The presence of high numbers of marine/brackish water marker diatoms suggests a paleotidal environment of marine/brackish water with a salinity greater than $5 \%$. The lack of variation in counts does not provide sufficient information to further define the paleotidal environments of Mu3.

Diatom analysis of samples from core 450, a continuous peat core, shows marker diatom counts proportional to those seen in core 449 , a core with three buried peat sequences. 
Core site 449 is approximately $3 \mathrm{~km}$ northeast of core site 450 (figure 17). These samples were taken at the same depths as those of core 449. It would appear that the area represented by core 450 experienced the same tidal environment changes as core 449 but that episodic burial events did not occur. This suggests that the area of core site 450 submerged without episodic burial. This would indicate that core site 450 was closer to the zero-isobase than core site 449 during the period of time encompassed by the three burial events. The area of core 450 experienced minimal vertical displacement relative to mean sea level due to its proximity to the zero-isobase during this time.

Five marsh units from core 470 located in Pony Slough were sampled for diatom analysis (TABLE XIX). Counts of marker diatoms show a pattern of low counts of marker diatoms in the peat samples and high counts of marker diatoms in the mud samples taken just above the peats. This suggests the successive development of uppermost intertidal marsh/forest environments followed by subsidence and burial by bay mud sediments. The present-day environment of Pony Slough, where this core was taken, is now a high-tidal to supratidal marsh with a developing forest at the edges of the marsh. The burial of these supratidal marsh or forest surfaces by bay mud sediments requires a minimum of 1 to $2 \mathrm{~m}$ of vertical drop (subsidence). 
TABLE XIX

SOUTHERN COOS BAY AREA MARINE/BRACKISH (M/B)

DIATOM ASSEMBLAGE

SUMMARY OF CORE 470

\begin{tabular}{ccc} 
BURIED PEAT MU \# & MATERIAL AND DEPTH & TOTAL COUNT OF \\
\hline Mu1 & Mudtop @ M DIATOMS \\
& Peat @ $68 \mathrm{~cm}$ & 62 \\
Mu2 & Mudtop @ $110 \mathrm{~cm}$ & 3 \\
& Peat @ $115 \mathrm{~cm}$ & 33 \\
Mu3 & Mudtop @ $175 \mathrm{~cm}$ & 21 \\
& Peat @ $185 \mathrm{~cm}$ & mostly fw \\
Mu4 & Mudtop @ $240 \mathrm{~cm}$ & 12 \\
& peat @ $250 \mathrm{~cm}$ & 15 \\
Mu5 & Mudtop @ $295 \mathrm{~cm}$ & 20 \\
& Peat @ $310 \mathrm{~cm}$ & 4
\end{tabular}

* Note: Buried marsh units are keyed - Mu1, Mu2, Mu3, etc. (see METHODS, Eigure 4, p. 25). $\mathrm{fw}_{\mathrm{w}}=$ fresh water diatoms, salinity is $<5 \%$.

The transition from non-episodic peat to episodically buried peat sequences in the coos Bay area is seen at Smith Ranch $20 \mathrm{~km}$ due east of the ocean and $105 \mathrm{~km}$ from the trench. This area of transition is interpreted by the author as the landward extent of the zero-isobase in the coos Bay area. 
Discussion summary

The records of abrupt coastal subsidence and uplift seen across the entire study area on the south-central oregon coast supports arguments for seismic activity in the Holocene. Radiocarbon dating of selected buried peat sequences from cores taken across the study area allows for the calculation of an average recurrence interval between successive subsidence events for the entire area. The average recurrence intervals range from 366 years to 670 years (TABLE XX). The geometric mean of the recurrence intervals is 480 years. A more conservative figure results when using the geometric mean because it is not so heavily weighted by extreme values and is usually used by researchers when comparing recurrence intervals from different study areas for a specific subduction zone. One drawback to using the geometric mean in this application is that it represents the mean of collected recurrence averages rather than the mean of the actual dates. This author has compared radiocarbon dates across the study area and notes a number of burial events which appear to cluster at roughly similar intervals (TABLE XV). One cluster of peat dates occurs between 300 to 400 RCYBP, a second is centered about 600 RCYBP, another is centered about 1000 RCYBP, another is centered about 1400 RCYBP, and a fifth cluster is at about 1900 RCYBP. These clusters of dates more accurately reflect 
TABLE XX

STUDY AREA RECURRENCE INTERVALS (R.I.)

$\begin{array}{lccc}\text { AREA } & \text { CORE NUMBERS } & \text { NUMBER OF EVENTS } & \text { R. I. } \\ \text { Siuslaw } & 216 & 5 & 400 \text { yrs } \\ \text { Umpqua } & 311,339 & 4 \text { total } & 520 \text { yrs } \\ \text { CoOs Bay } & 448,449 & 6 & 366 \text { yrs } \\ & 462 & 9 & 390 \text { yrs } \\ & 408 & 6 & 594 \text { yrs } \\ 470 & 5 & 670 \text { yrs }\end{array}$

this author's interpretation of the data and yields a recurrence interval of 400 years.

Anomalous sand layers appear in or above peaty sequences in cores taken from across the study area. In the siuslaw Bay area there are five cores, in the Umpqua River area there are 14 cores, and in the coos Bay area there are 12 cores for a total of 31 cores which contain evidence of anomalous thin sand layers. The presence of these thin sand layers and the attenuation or absence of these layers with distance landward suggests the potential for tsunami inundation following coseismic dislocation of the Cascadia subduction zone. 
Additional work is needed to test the origin of these anomalous sand layers. Further possible evidence of seismic events in these bays is the presence of liquefaction features observed in cores from the Siuslaw Bay and the Umpqua River areas.

The analysis of diatom assemblages observed in core samples provides information about the paleotidal environment of the south-central oregon coast. The abrupt change in marker diatom counts, from a count of few or no marine/brackish water diatoms in some buried peats to a high count of these diatoms in the overlying mud flat deposits and the analysis of plant fossil abundance (percent organic material) suggests relative sea-level displacement of 1 to 2 $m$. The fact that many cores do not show evidence of episodic sea-level rise means that the observed submergence events are not eustatic in nature. Evidence of vertical drop of this magnitude is seen from Siuslaw Bay south to coos Bay.

The Siuslaw Bay, Umpqua River, and Coos Bay areas all contain evidence of a transition zone where the cores change in nature from non-episodic buried wetlands characterized by continuous peat or containing evidence of one buried wetland to episodically buried wetland deposits. In Siuslaw Bay this zone is $105 \mathrm{~km}$ from the trench. The transition zone is 114 $\mathrm{km}$ from the trench in the Umpqua River area. In coos Bay the area of transition is $105 \mathrm{~km}$ from the trench. These transition zones indicate the apparent landward extent of the 
zero-isobase on the south-central oregon coast (Eigure 19). The maximum width of the zero-isobase cannot be determined since its oceanward extent is unknown. However, in this area the zero-isobase has a minimum width of 10 to $15 \mathrm{~km}$.

Predictive dislocation fit models created by Hyndman and Wang (1993) suggest that the zero-isobase is 90-100 km from the trench in the central cascadia margin. This author has defined the landward extent of the zero-isobase to be $100 \mathrm{~km}$ to $120 \mathrm{~km}$ from the trench which agrees well with Hyndman and Wang's model for this area. The regional variations displayed in late Pleistocene marine terraces along Pacific Northwest coast (Mulder, 1992) as well as recent mapping by Goldfinger (1992) of offshore folds and faults along the northern Oregon coast predict the landward attenuation of this upper plate vertical deformation, at some $100 \mathrm{~km}$ from the trench in the north-central cascadia margin. The results of new geologic mapping and the compilation of structure data from previously mapped Tertiary bedrock show that the onshore fold belt terminates $100-110 \mathrm{~km}$ from the trench near catching Slough in Coos Bay (Black, 1993). At approximately 100-120 $\mathrm{km}$ from the trench, upper plate deformation abruptly decreases in amplitude with increasing distance landward as indicated by Newton's (1980) mapping of structure data along west-east traverses in this area. Based on the work by others discussed above and the results of this study, this author interprets the apparent overlapping of the landward 


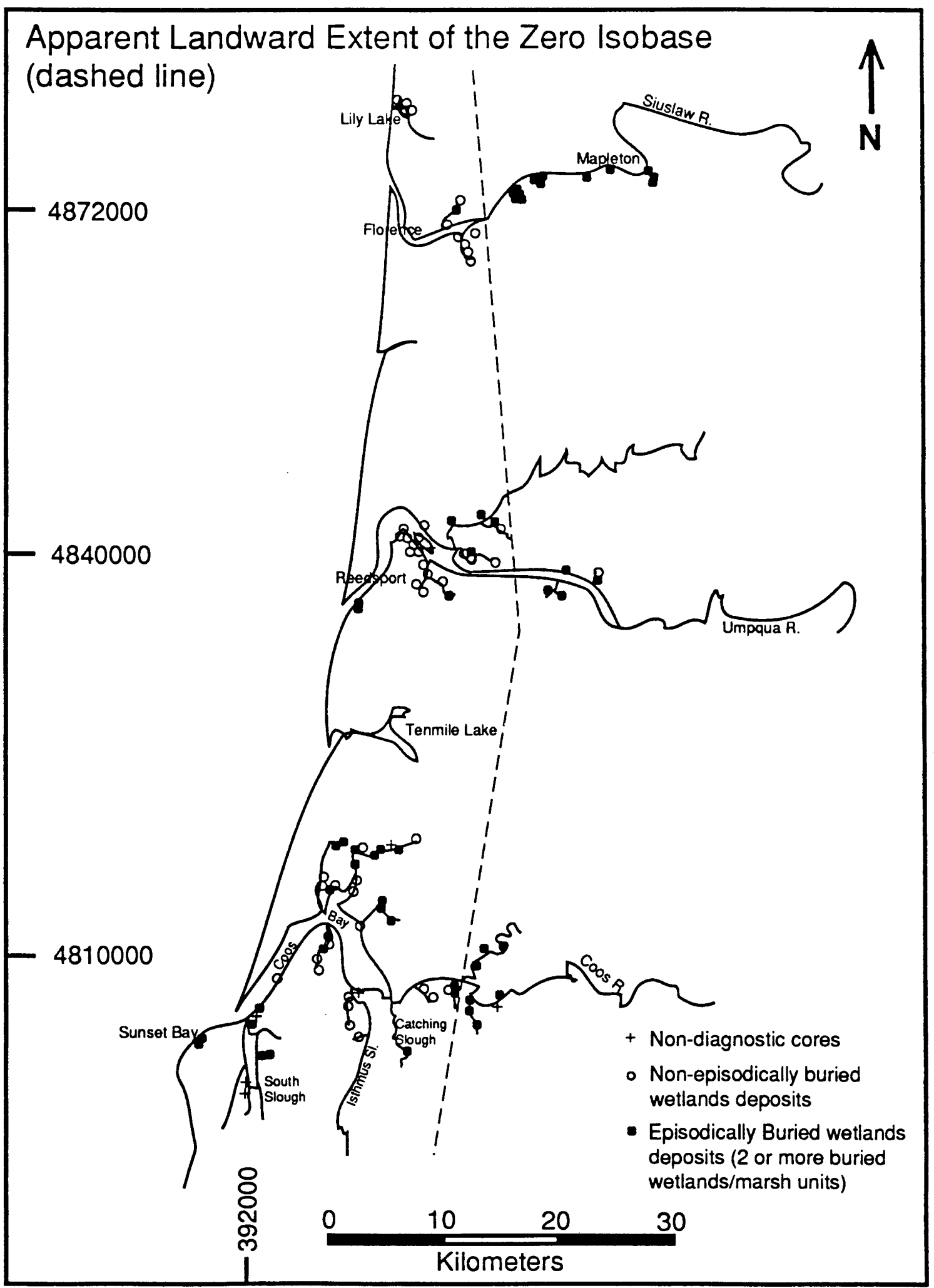

Figure 19. Landward extent map of the zero-isobase, as determined by buried marsh stratigraphy. 
boundaries of both the observed upperpiate deformation (folding) and the landward extent of the late Holocene zeroisobase as the landward limit of the locked zone (between 100 $\mathrm{km}$ and $120 \mathrm{~km}$ ) from the trench in the south-central Cascadia margin.

Using the Wyss equation, which is $\mathrm{M}_{\max }=\log \mathrm{A}+4.15$, where $A$ is the area of rupture (Darienzo, 1991), the estimated earthquake magnitude can be calculated. Based on an arbitrary rupture length of $200 \mathrm{~km}$ and a rupture width of $105 \mathrm{~km}$, the earthquake magnitude is 8.5 .

\section{CONCLUSIONS}

The records of abruptly buried peat sequences seen in the areas of Siuslaw Bay, Umpqua River, and Coos Bay reflect tectonic subsidence resulting from earthquakes on the Cascadia margin. A transition zone along the south-central Oregon coast contains non-episodic cores characterized by continuous peat or one buried wetland mixed with cores that show episodically buried wetlands. This transition zone represents the landward extent of the zero-isobase and occurs at a distance of about $100 \mathrm{~km}$ to $120 \mathrm{~km}$ from the trench. The zero-isobase has a minimum width of 10 to $15 \mathrm{~km}$.

In coos Bay, cores were taken in areas of locally developed synclinal structures. The radiocarbon dates of 
episodically buried peats in cores from this area coupled with a record of modern low seismicity under conditions of accumulating elastic strain suggest that the activities of these local structures are linked to megathrust releases. If these local faults and fold are triggered by megathrust releases, the burial events associated with these local structures occurred simultaneously with the releases or shortly thereafter.

Analysis of plant fossil abundance (percent organic material) and diatom assemblages provides evidence of vertical displacement on the magnitude of 1 to $2 \mathrm{~m}$. In some structures possible tsunami inundations associated with Cascadia subduction zone dislocations are indicated by the presence of anomalous thin sand layers, as seen in a number of core peaty sections.

The estimated recurrence interval between successive subsidence events, based on the radiocarbon dating of selected buried peat sequences of representative cores is 400 years.

\section{RECOMMENDATIONS}

Additional close space coring of the south-central oregon coast is needed to provide a detailed stratigraphic record of coastal subsidence that can link widely separated 
bays to regional events. Radiocarbon dating of the peat below tsunami sands is also needed to correlate corresponding tsunami inundation to regional events.

A seismic refraction profile is needed to identify the local structure seen in Pony Slough (the occurrence of five events in the past 3700 years defines it as an active fault by federal guidelines). Diatom analysis of five events in the past 3700 years indicates vertical displacements of $1 \mathrm{~m}$ to $2 \mathrm{~m}$ for each event. The water supply for the city of coos Bay is stored behind an earthen dam located on the upper portion of Pony Creek. Supplemental seismic data can be helpful in the assessment of the threat to the dam in the event of a large earthquake. 


\section{REFERENCES}

Adams, J., 1990. Paleoseismicity of the Cascadia subduction zone: evidence from turbidites off the Oregon-Washington margin. Tectonics, 9:569-583.

Allen, J.E. and E.M. Baldwin, 1944. Geology and coal resources of the Coos Bay quadrangle, Oregon. Department of Geology and Mineral Industries, Bulletin No. 27, $159 \mathrm{p}$.

Amspoker, M.C. and C.D. McIntire, 1978. Distribution of intertidal diatoms associated with sediments in Yaquina Estuary, Oregon. J. Phycol. 14:387-395.

Ando, M. and F.I. Balazs, 1979. Geodetic evidence for aseismic subduction of the Juan de Fuca plate. Journal of Geophysical Research, 84, 3023-3028.

Atwater, B.F., 1992. Geologic eidence for earthquakes during the past 2000 years along the copalis River, southern coastal Washington. Journal of Geophysical Research, no. B2, $97: 1901-1919$.

Atwater, B.F., M. Stuiver, and D.K. Yamaguchi, 1991. Radiocarbon test of earthquake magnitude at the Cascadia subduction zone. Nature, 353:156-158.

Atwater, B.F., 1987. Evidence for great Holocene earthquakes along the outer coast of Washington state. Science, $v$. 236, p. $942-944$.

Atwater, T., 1970. Implications of plate tectonics for the Cenozoic tectonic evolution of western North America. Geological Society of America Bulletin, 81:3513-3536.

Baldwin, E.M., 1966. Some revisions of the geology of Coos Bay area, Oregon. Ore Bin, 28, 189-204.

Black, G.L, 1993. Offshore-onshore geologic cross section from the Pan American Corporation well (continental shelf) to the Umpqua River (southern Oregon Coast Ranges). Oregon Department of Geology and Mineral Industries. 1 Map and cross-sections, Scale 1:100,000.

Briggs, G., and C.D. Peterson, 1993. Neotectonics of the central Cascadia margin as recorded in south-central Oregon coastal deposits. Final Report to NEHRP Summaries, $80 \mathrm{p}$. 
Briggs, G.G., and C.D. Peterson, 1992. Neotectonics of the south-central oregon coast as recorded by late Holocene paleosubsidence of marsh systems. Geological society of America Cordilleran Section Meeting, Eugene, Oregon, Abstract.

Byrne, D.E., D.M. Davies, and L.R. Sykes, 1988. Loci and maximum size of thrust earthquakes and the mechanics of the shallow region of subduction zones. Tectonics, 7 , 833-857.

Carver, G.A., 1991. Cascadia subduction zone earthquake workshop fieldtrip Humboldt County, Calif. Humboldt State University, $23 \mathrm{p}$.

Clarke, S.J. and Carver, G.A., 1992. Late Holocene tectonics and paleoseismicity, southern Cascadia subduction zone. Science, v. 255, p.188-192.

Clarke, S., 1991. Offshore neotectonics of the Cascadia subduction zone, Gorda segment (abstract). Oregon Department of Geology and Mineral Industries Workshop on Oregon Earthquake Source Zones, Corvallis, Oregon.

Crosson, R.S., and Owens, T.J., 1987. Slab geometry of the Cascadia subduction zone beneath Washington from earthquake hypocenters and teleseismic converted waves. Geophysical Research Letters, 14:824-827.

Crosson, R.S., 1983. Review of seismicity in the Puget Sound region from 1970 through 1978. Proceedings of Workshop XIV, Earthquake Hazards of the Puget Sound Region, Washington, USGS Open File Rept. 83-19, pp. 6-18.

Cupp, E.E., 1943. Marine plankton diatoms of the west coast of North America. Bulletin of the Scripps Institution of Oceanography, 5:1-195.

Darienzo, M.E., 1991. Late Holocene paleoseismicity along the northern Oregon coast. Ph.D. dissertation, Portland State University, Portland, Oregon. $167 \mathrm{p}$.

Darienzo, M.E. and C.D. Peterson, 1990. Episodic tectonic subsidence of late-Holocene salt marsh sequences in Netarts Bay, Oregon, Central Cascadia Margin, USA. Tectonics, $9: 1-22$. 
Goldfinger, C., L.D. Kulm, R.S. Yeats, B. Applegate, M.E. Mackay, G.F. Moore, 1992. Transverse structural trends along the Oregon convergent margin: Implications for Cascadia earthquake potential and crustal rotations. Geology, 20:141-144.

Goldfinger, C., L.D. Kulm, R.S. Yeats, C.Mitchell, R. WeldonII, C. Peterson, M. Darienzo, W.Grant and G.R. Priest, 1992. Neotectonic map of the oregon continental margin and adjacent abyssal plain. Oregon Department of Geology and Mineral Industries, Open-File Report 0-92-4, 17 p. and Map.

Grant, W.C., 1989. More evidence from tidal-marsh stratigraphy for multiple late Holocene subduction earthquakes along the northern Oregon coast (abstract). Geological Society of America Abstracts with Programs, 21,86 .

Grant, W.C., B.F. Atwater, G.A. Carver, M.E. Darienzo, A.R. Nelson, C.D. Peterson, and G.S. Vick, 1989. Radiocarbon dating of late Holocene coastal subsidence above the Cascadia Subduction Zone-Compilation for Washington, Oregon, and northern California (abstract). EOS, 70, 1331 .

Grant, W.C. and D.D. McLaren, 1987. Evidence for Holocene subduction earthquakes along the northern oregon coast (abstract). EOS, 68, 1469.

Heaton, T.H. and S.H. Hartzell, 1987. Earthquakes hazards on the Cascadia Subduction Zone. Science, 236, 162-168.

Heaton, T.H. and S.H. Hartzell, 1986. Source characteristics of hypothetical subduction earthquakes in the northwestern United States. Bull. Seismological Soc. Amer., $76: 675-708$.

Heaton, T.H. and H. Kanamori, 1984. Seismic potential associated with subduction in the northwestern United States. Bulletin of the seismological society of America, 74, 933-941.

Hyndman, R.D., and K. Wang, 1993. Thermal constraints on the zone of major thrust earthquake failure: The Cascadia subduction zone. Journal of Geophysical Research, 98:2039-2060. 
Karentz, D. and C.D. McIntire, 1977. Distribution of diatoms in the plankton of Yaquina Estuary, Oregon. J. Phycol. $13: 379-388$.

Kelsey, H.M., 1990. Late Quaternary deformation of marine terraces on the Cascadia subduction zone near cape Blanco, oregon. Tectonics, 9:983-1014.

Main, S.P. and C.D. McIntire, 1974. The distribution of epiphytic diatoms in Yaquina Estuary, Oregon (USA). Botanica Marina, 17:88-99.

McInelly, G.W., H.M. Kelsey, 1990. Late Quaternary tectonic deformation in the Cape Arago-Bandon region of coastal oregon as deduced from wave-cut platforms. J. Geophys. Res., 95:6699-6713.

McIntire, C.D., 1978. The distribution of estuarine diatoms along environmental gradients: A canonical correlation. Estuarine and Coastal Marine Science, 6:447-457.

Moore, W.W. and C.D. McIntire, 1977. Spatial and seasonal distribution of littoral diatoms in Yaquina Estuary, oregon (USA). Botanica Marina, 20:99-109.

Muhs, D.R., H.M. Kelsey, G.H. Miller, G.L. Kennedy, J.F. Whelan, and G.W. McInelly, 1990. Age estimates and uplift rates for late-Pleistocene marine terraces: Southern Oregon portion of the Cascadia forearc. J. Geophys. Res., 95:6685-6698.

Mulder, R., 1992. Regional tectonic deformation of the northern oregon coast as recorded by Pleistocene marine terraces. M.S. Thesis, Portland state University, Portland, Oregon. $91 \mathrm{p}$.

Nelson, A.R., 1992. Discordant ${ }^{14} \mathrm{C}$ ages from buried tidalmarsh soils in the Cascadia subduction zone, southern oregon coast. Quaternary Res., 38:74-90.

Nelson, A.R., 1992. Great subduction-zone earthquakes in the Pacific Northwest? Differentiationg coseismic from nontectonic tidal-marsh deposits along the Oregon coast. Proceedings of the Assoc. of Engineerining Geologists, 35th Annual Meeting, pp. 284-290.

Newton, V.C., 1980. Geologic Maps: Northern and Southern Coos Basins; Oil and Gas Investigation 6. Oregon Department of Geology and Mineral Industries, $73 \mathrm{p}$. and 2 Maps: Scale 1:62500. 
Patrick, R. and C.W. Reimer, 1975. The diatoms of the United States. Academy of Natural Sciences of Philadelphia, $2: 1-206$.

Patrick, R. and C.W. Reimer, 1966. The diatoms of the United States. Academy of Natural Sciences of Philadelphia, $1: 1-668$.

Peterson, C.D., M.E. Darienzo, S.F. Burns, and W.K. Burris, 1993. The paleoseismic record of subsidence, tsunamis, liquefaction, and landslides from the northern Oregon coast: Evidence of subduction zone seismicity in the central Cascadia margin. 26th Annual Pacific Cell Meeting, Friends of the Pleistocene, Field Trip Guide, $69 \mathrm{p}$.

Peterson, C.D., and G.G. Briggs, 1992. Response of coastal depositional systems to tectonic strain cycles in the Cascadia Subduction of the U.S. Pacific Northwest. 29 th International Geological Congress, Kyoto, Japan, invited, Abstract.

Peterson, C.D. and M.E. Darienzo, 1992. Discrimination of flood, storm and tectonic subsidence events in coastal marsh records of Alsea Bay, Central Cascadia Margin, USA. U.S. Geological Survey Open-File Report, OF $91-441-\mathrm{C}, 53 \mathrm{p}$.

Peterson, C.D. and J.B. Phipps, 1992. Holocene sedimentary framework of Gray's Harbor Basin, Washington, USA. Society for Sedimentary Geology 48:273-285.

Peterson, C.D. and M.E. Darienzo, 1989. Episodic, abrupt tectonic subsidence recorded in late Holocene deposits of the South Slough syncline: An on-land expression of shelf fold belt deformation from the southern cascadia margin. Geol. Soc. Am. Abstr. Programs, 21, 129.

Rao, V.N.R. and J. Lewwin, 1976. Benthic marine diatom flora of False Bay, San Juan Island, Washington. Syesis, $9: 173-213$.

Riddihough, R., 1984. Recent movements of the Juan de Fuca plate system. Journal of Geophysical Research, 89, 6980-6994. 
Riddihough, R.P., 1982. Contemporary movements and tectonics on Canada's west coast: A discussion. Technophysics, 86:319-349.

Riddihough, R., 1980. Gorda plate motions from magnetic anomoly analysis. Earth and Planetary Science Letters, $51: 163-170$.

Riznyk, R.z., 1973. Interstitial diatoms from two tidal flats in Yaquina Estuary, Oregon, USA. Botanica Marina $16: 113-138$.

Savage, J.C. and M. Lisowski, 1991. Strain measurements and the potential for a great subduction earthquake off the coast of Washington. Science, 252:101-103.

Savage, J.C., M. Lisowski, W.H. Prescott, 1981. Geodetic strain measurements in Washington. J. Geophys. Res. $86: 4929-4940$.

Spence, W., 1989. Stress origins and earthquake potentials in Cascadia. Journal of Geophysical Research, 94, 30763088

Weaver, C.S. and G.E. Baker, 1988. Geometry of the Juan de Fuca plate beneath washington and northern Oregon from seismicity. Bulletin of the seismological society of America, 78, 264-275.

Weber, C.I., 1971. A guide to the common diatoms at water pollution surveillance system stations. U.S.

Environmental Protection Agency, pp. 1-93.

Whiting, M.C. and C.D. MCIntire, 1985. An investigation of distributional patterns in the diatom flora of Netarts Bay, Oregon, by correspondence analysis. J. Phycol. $21: 655-661$. 
APPENDIX A

FIELD DATA CORE LOGS 
APPENDIX A

LIST OF LOG FIGURES

SIUSLAW AREA CORE NUMBERS

$\underline{\text { PAGE }}$

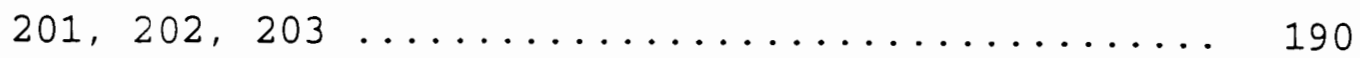

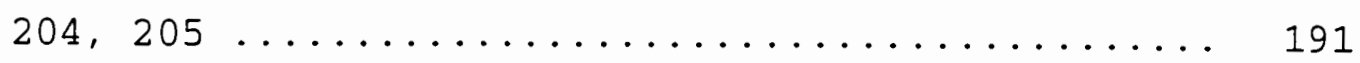

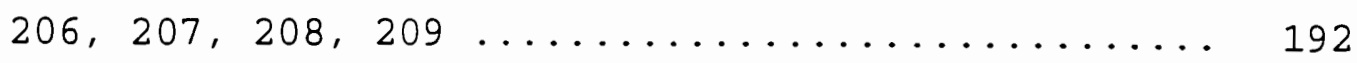

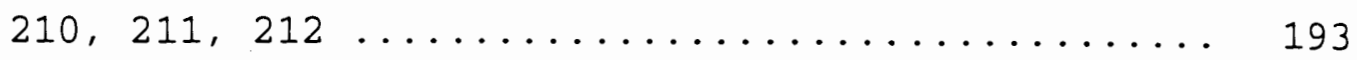

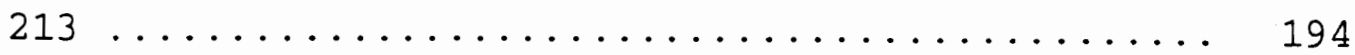

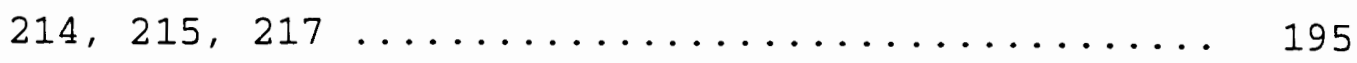

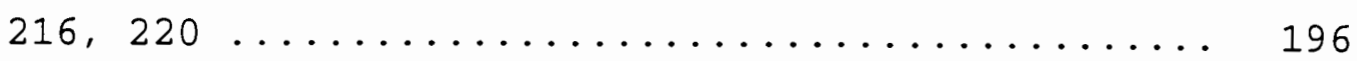

$218,219,221 \ldots \ldots \ldots \ldots \ldots \ldots \ldots \ldots \ldots \ldots \ldots \ldots \ldots \ldots$

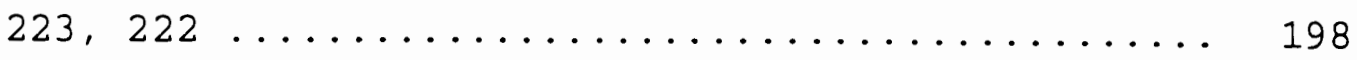

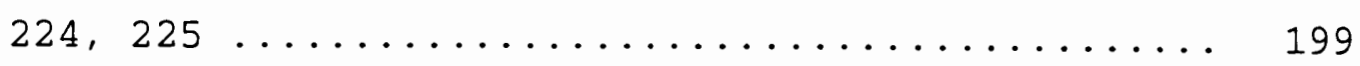

\section{UMPOUA AREA CORE NUMBERS}

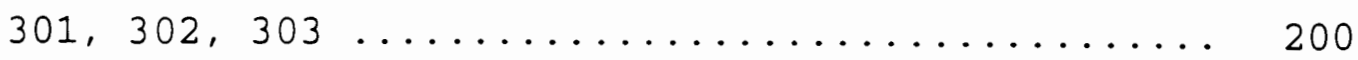

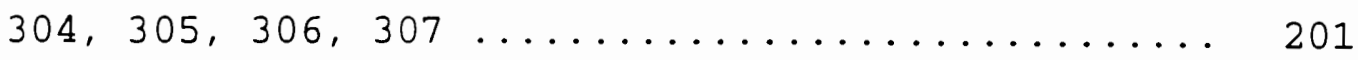

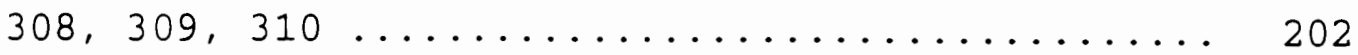

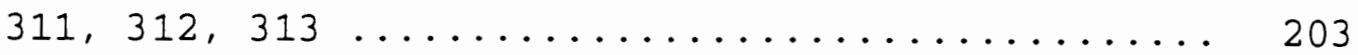

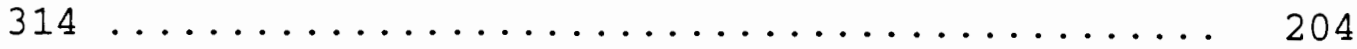

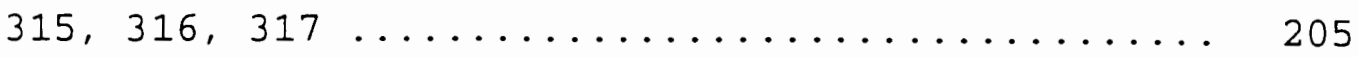

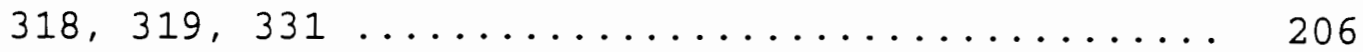

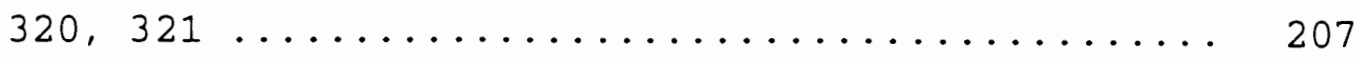

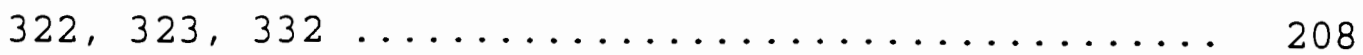

324 not assigned 


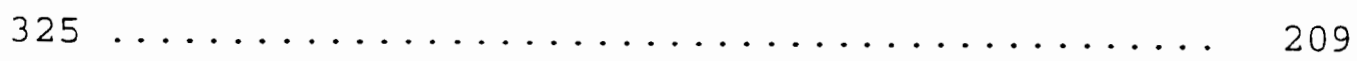

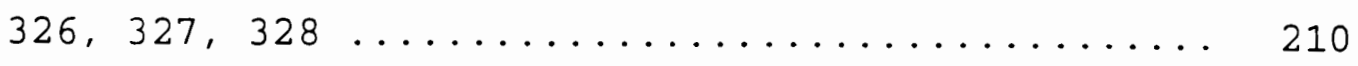

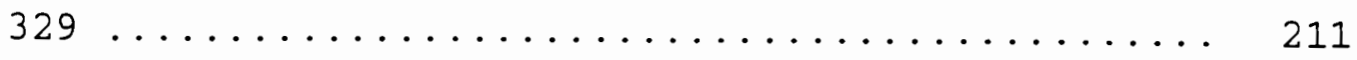

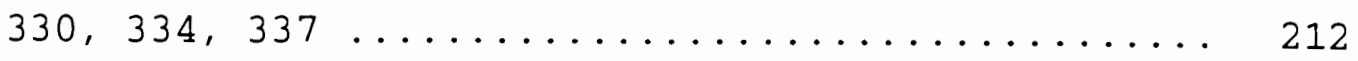

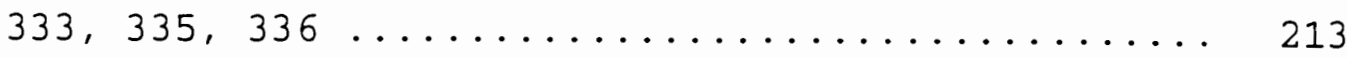

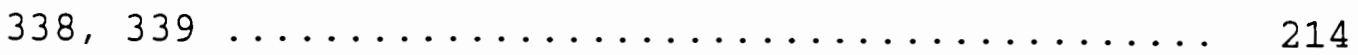

\section{COOS BAY AREA CORE NUMBERS}

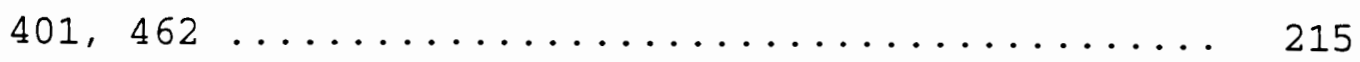

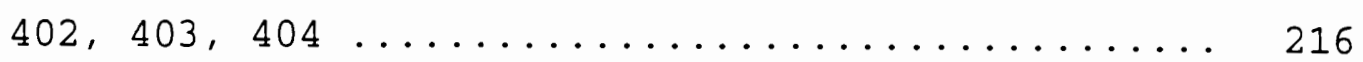

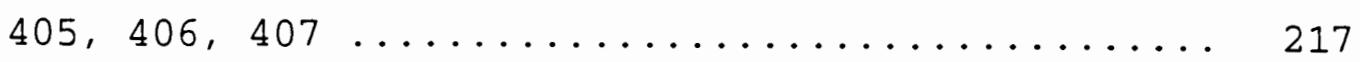

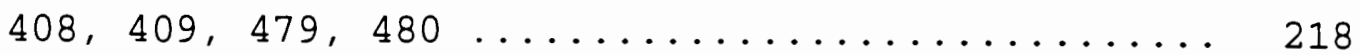

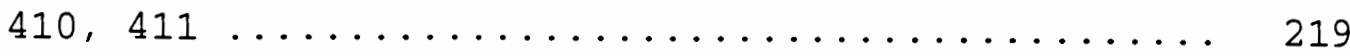

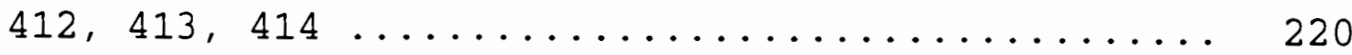

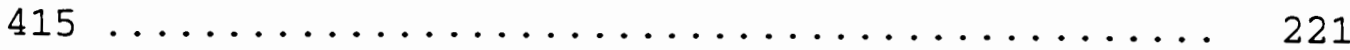

$416,422,423 \ldots \ldots \ldots \ldots \ldots \ldots \ldots \ldots \ldots \ldots \ldots \ldots \ldots \ldots \ldots \ldots \ldots \ldots \ldots, 222$

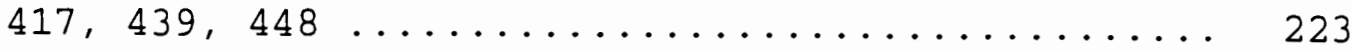

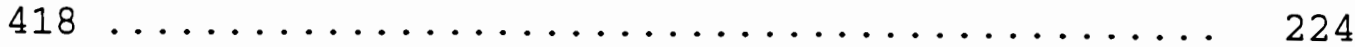

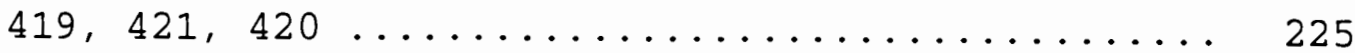

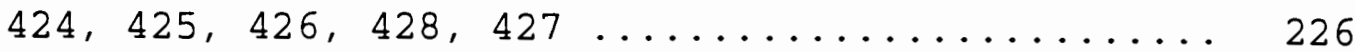

429 and 430 not assigned

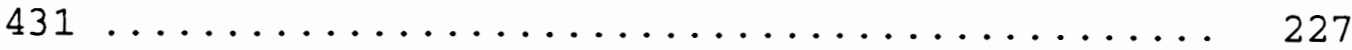

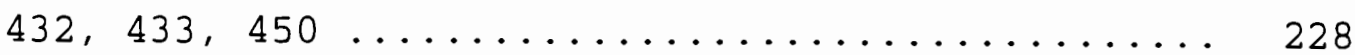

$435,434,436,437,438 \ldots \ldots \ldots \ldots \ldots \ldots \ldots \ldots \ldots$

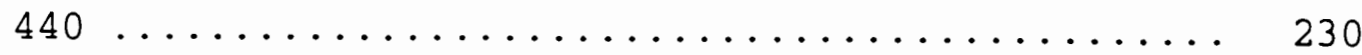




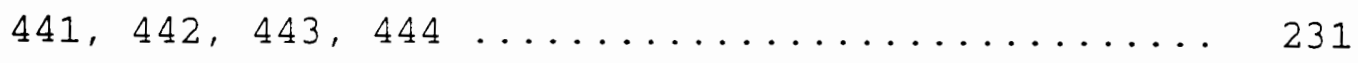

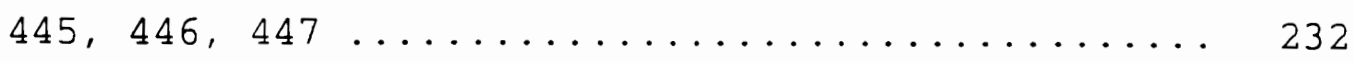

$451,455,(452,453,454$, same as 451) ...... 233

$458,456,457$, (459 same as 458) .......... 234

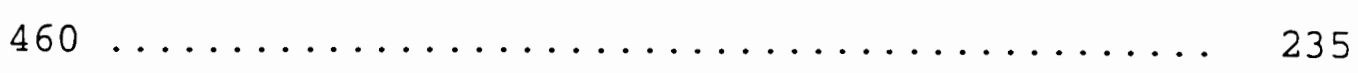

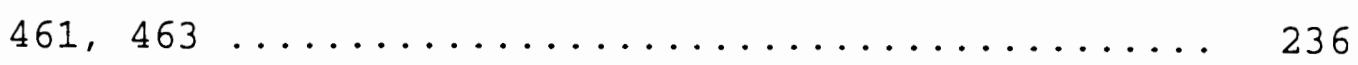

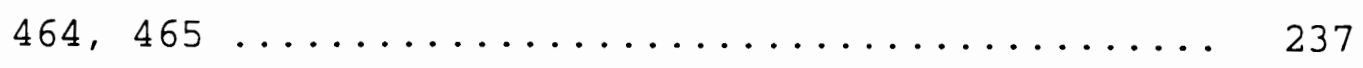

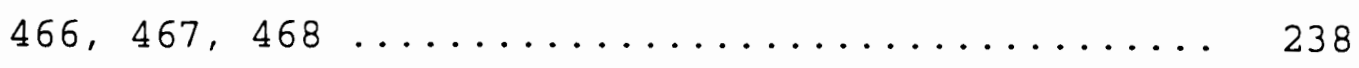

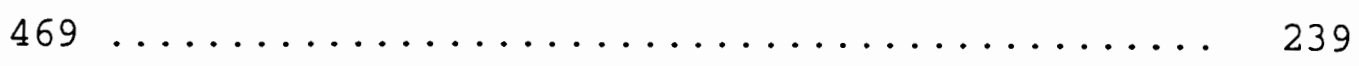

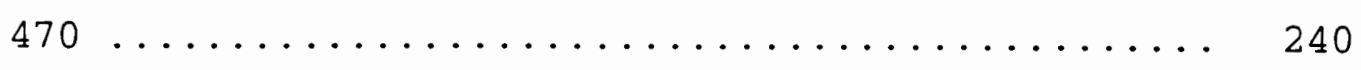

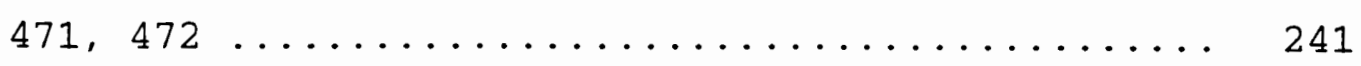

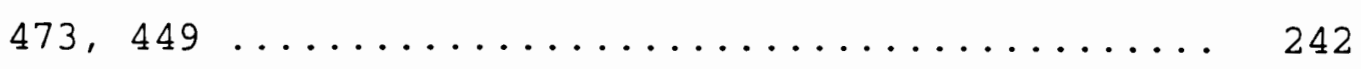

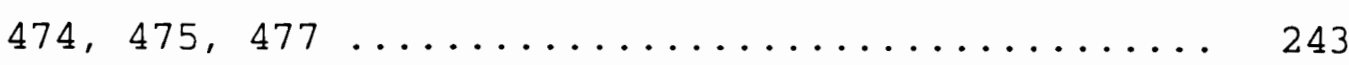

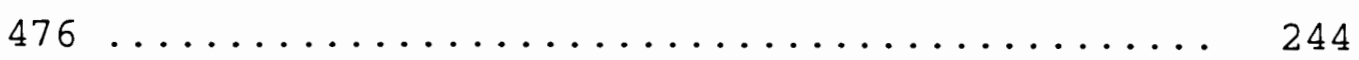

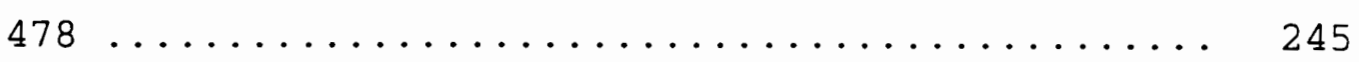


Siuslaw Cores: Haring Ck., Bernhardt Ck., Hoffman Ck.
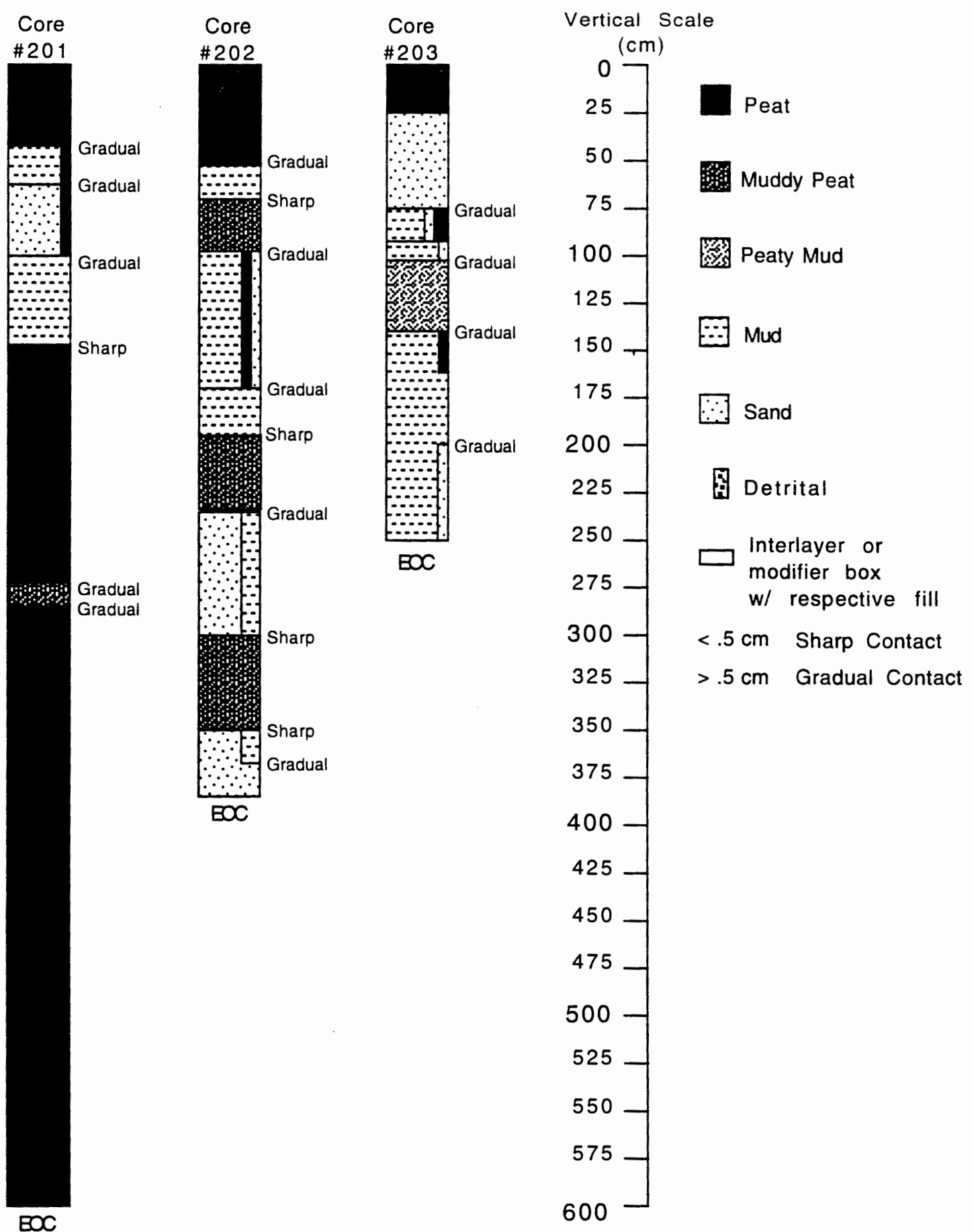
Lily Lake Cores
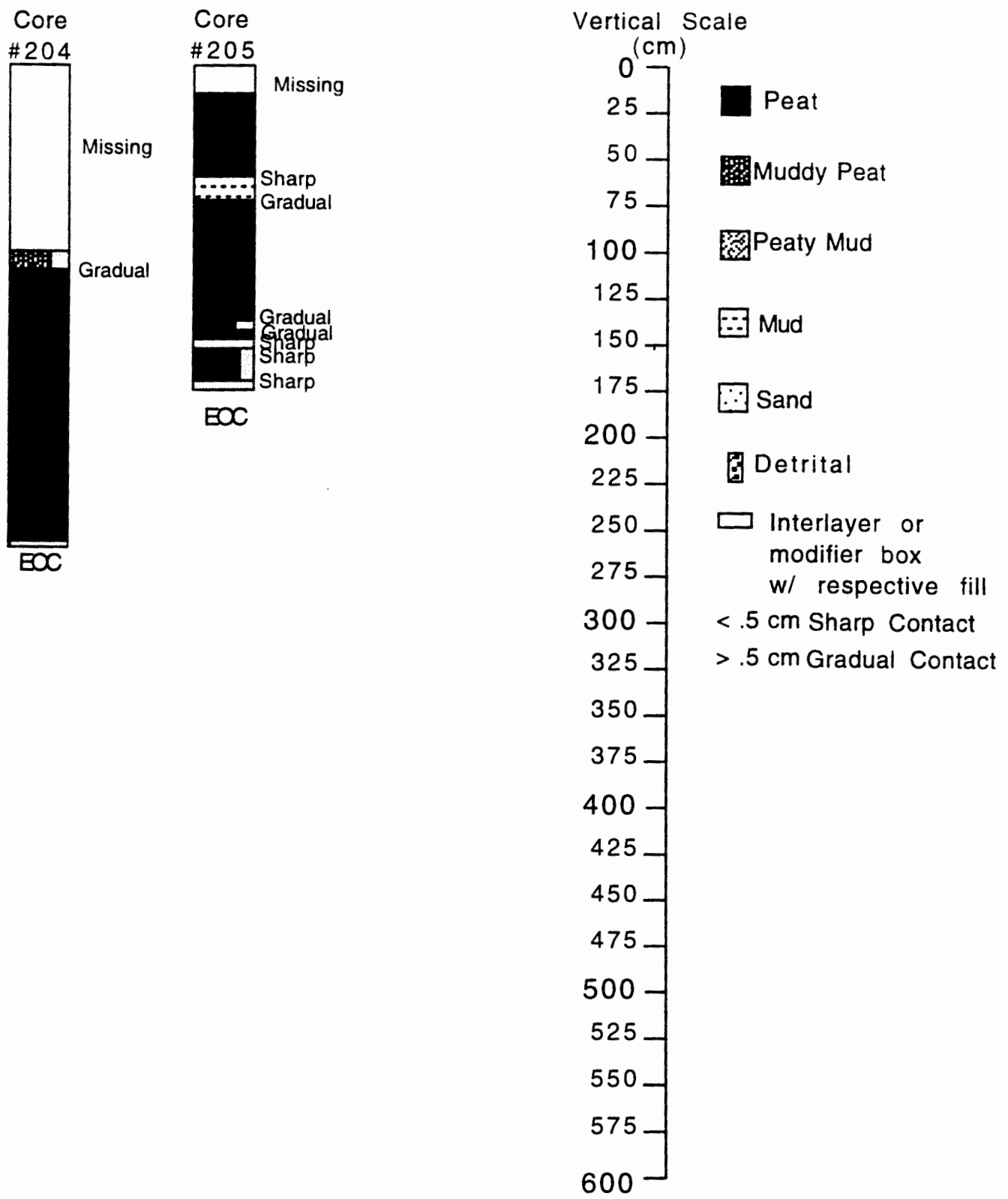
Siuslaw Cores

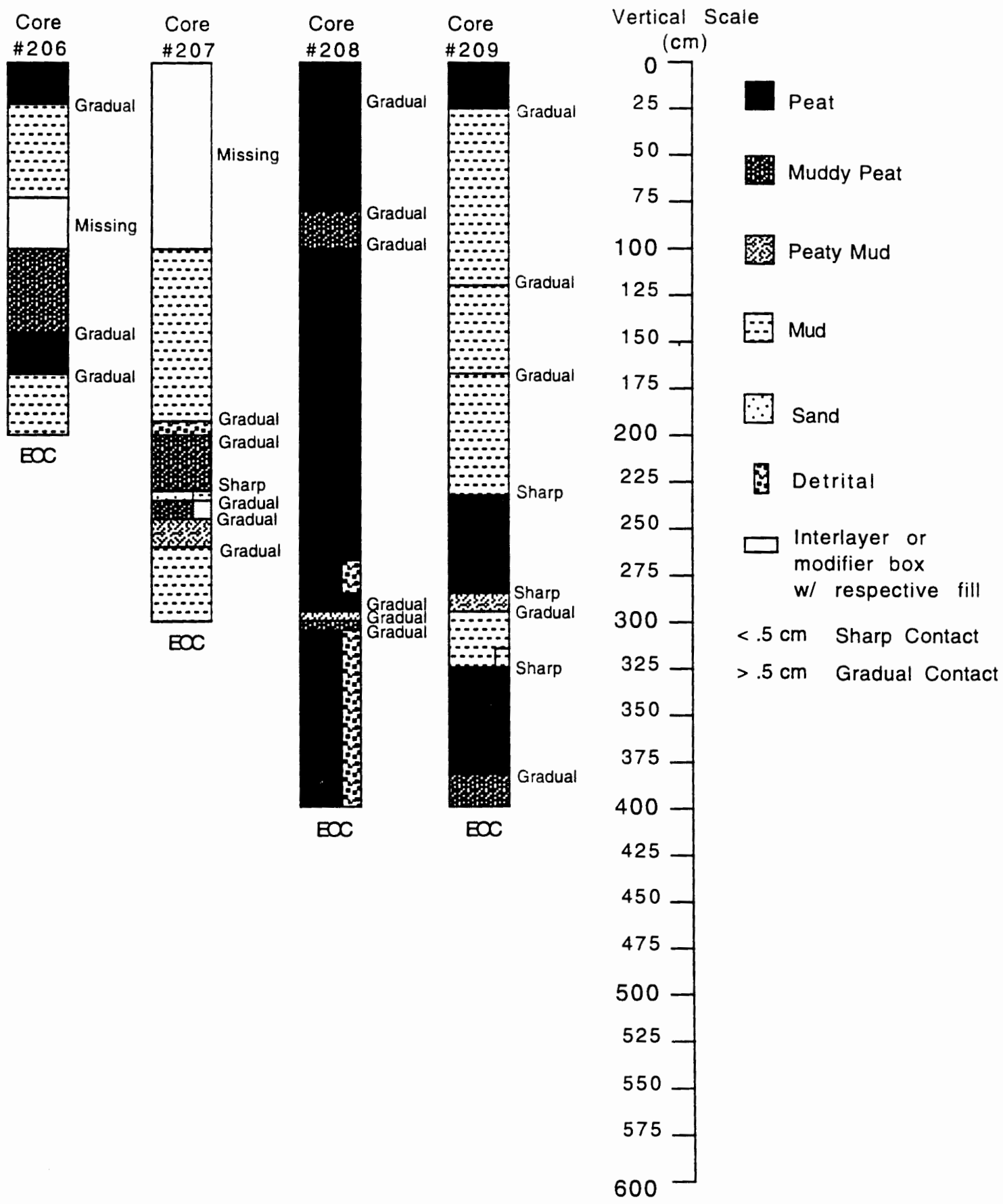


Siuslaw, Berhard
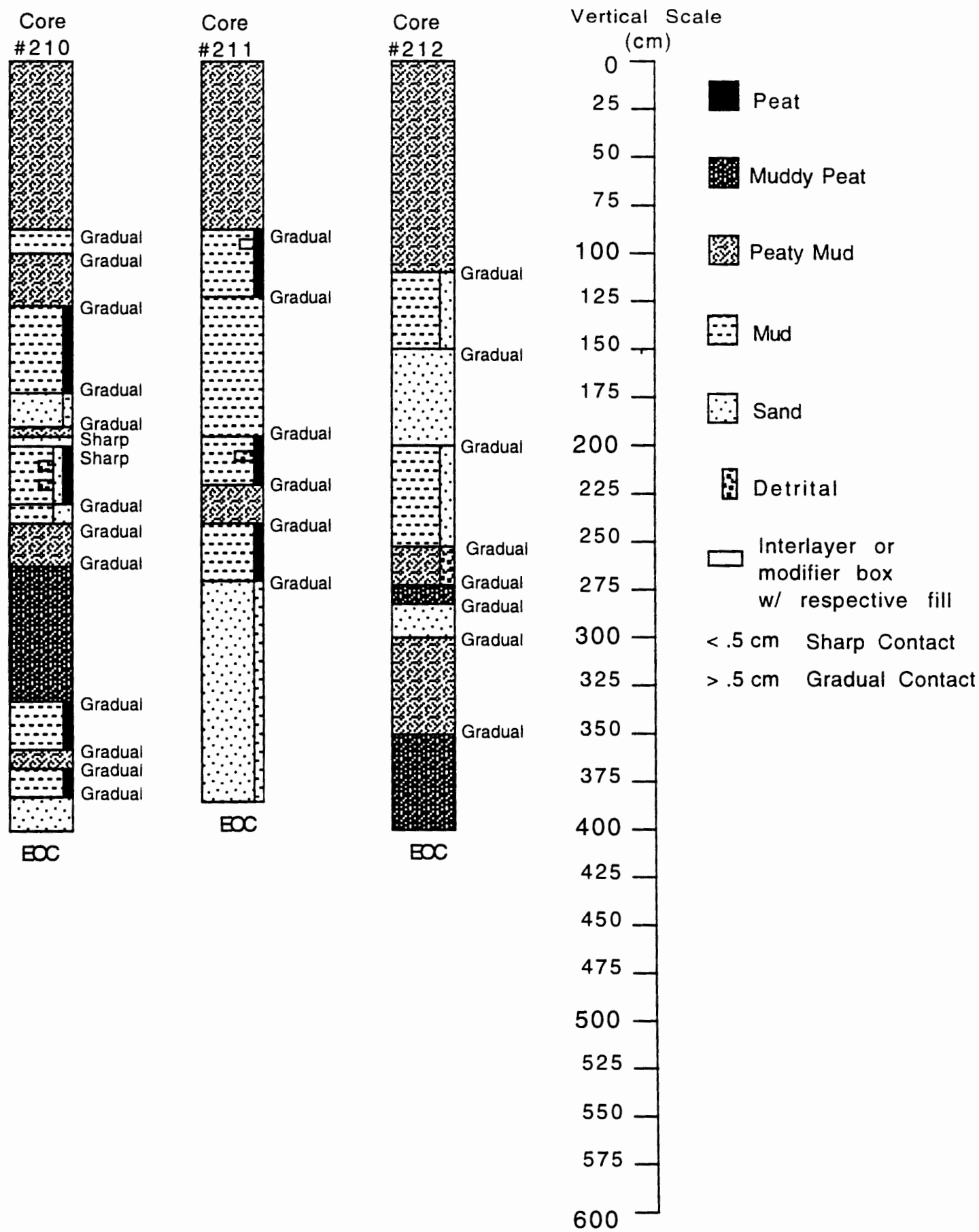
Siuslaw, Bernhard

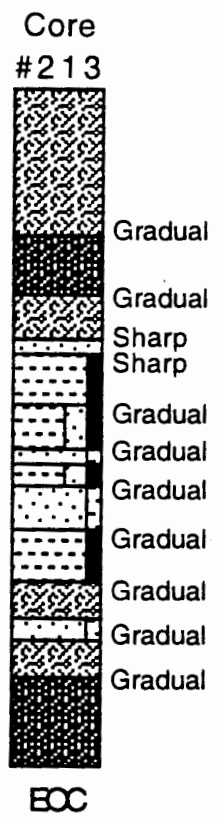

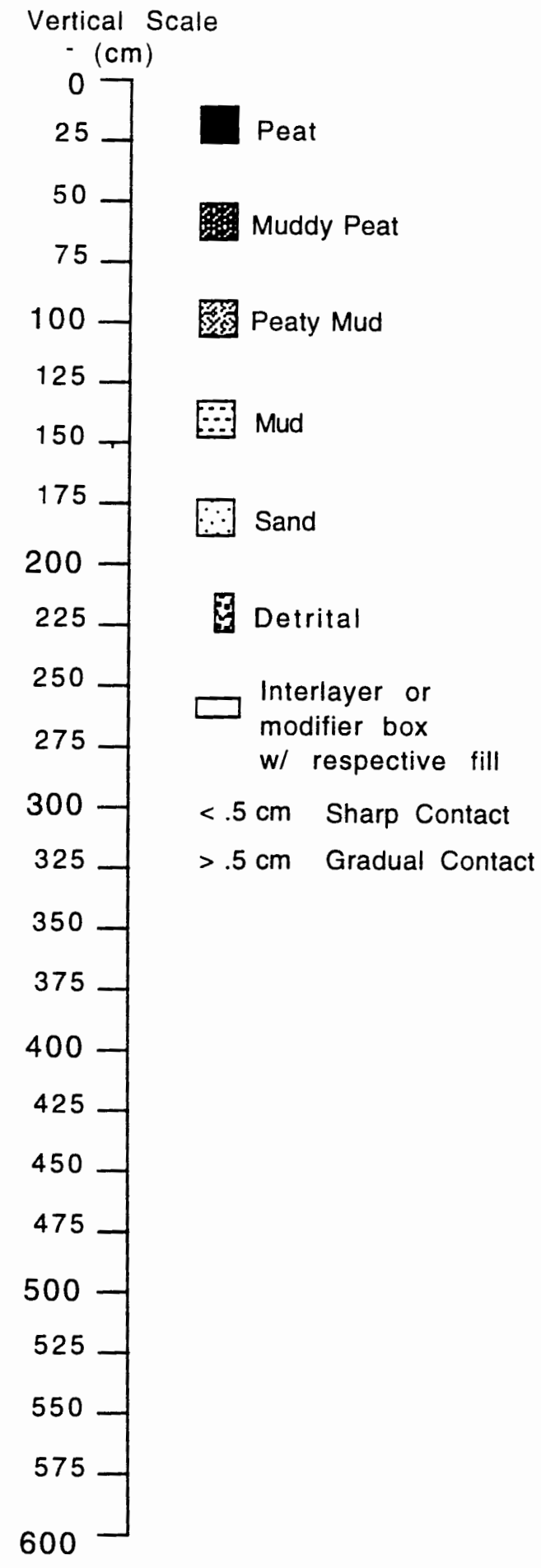



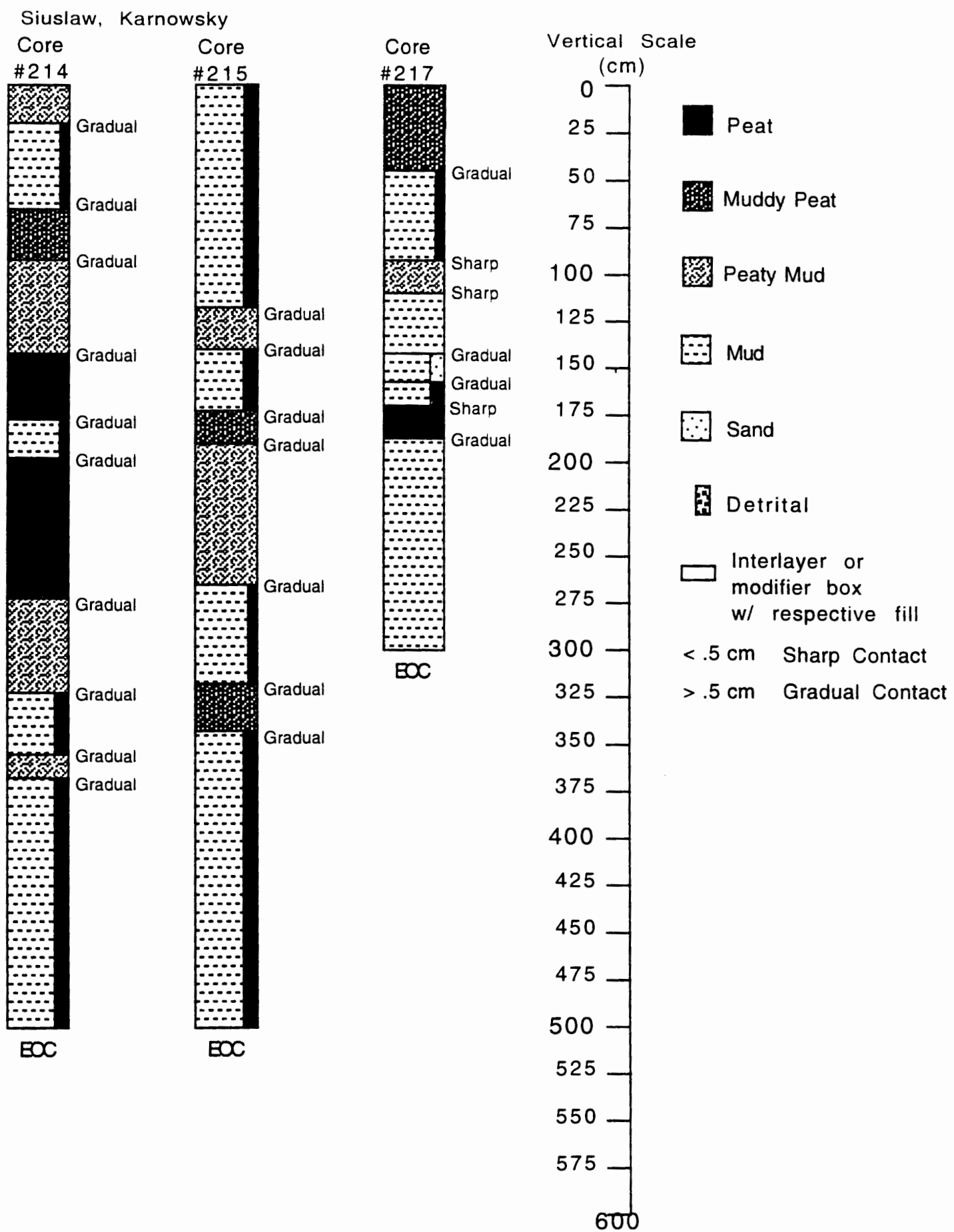
Siuslaw, Karnowsky Ck, Hadsall Ck (PC's)

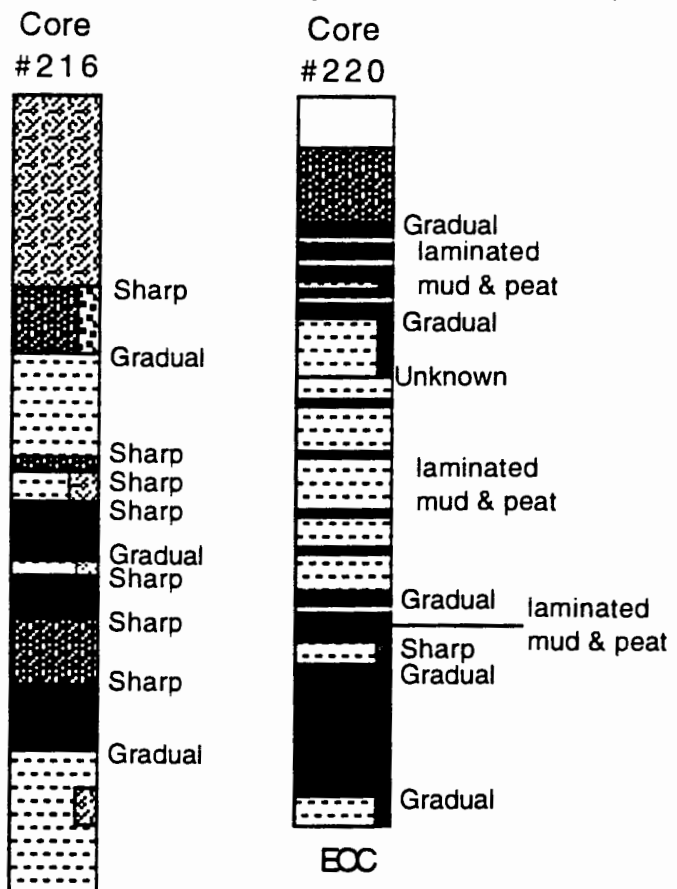

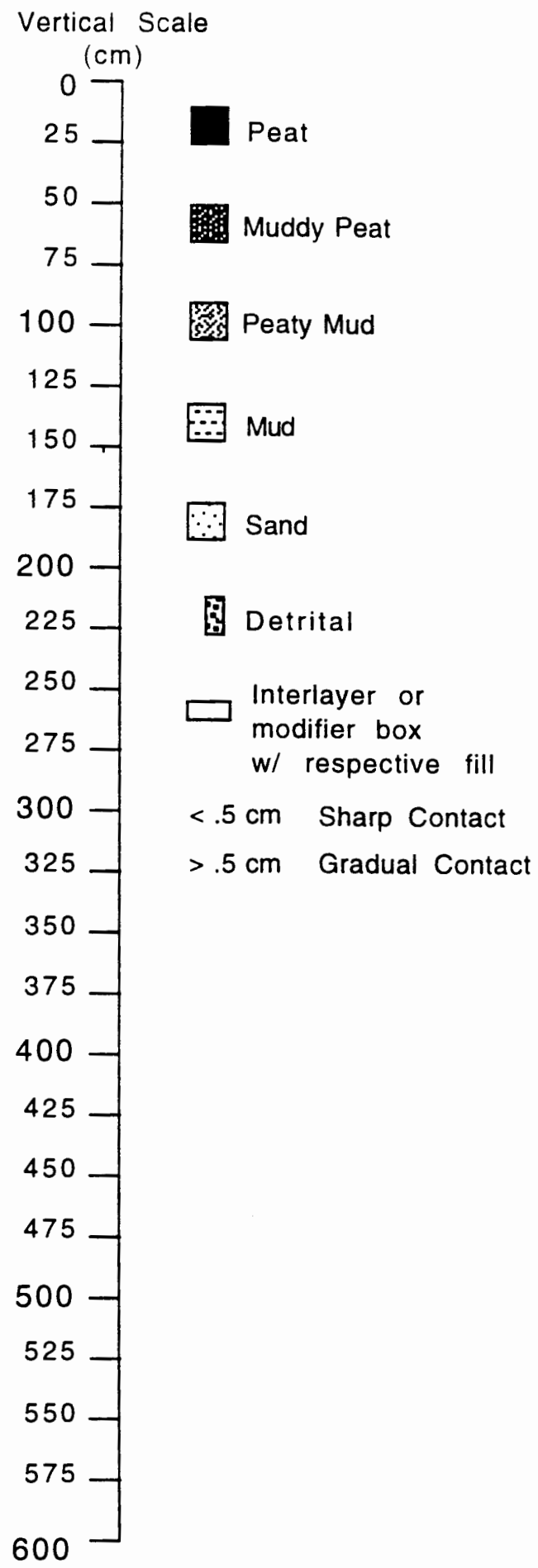



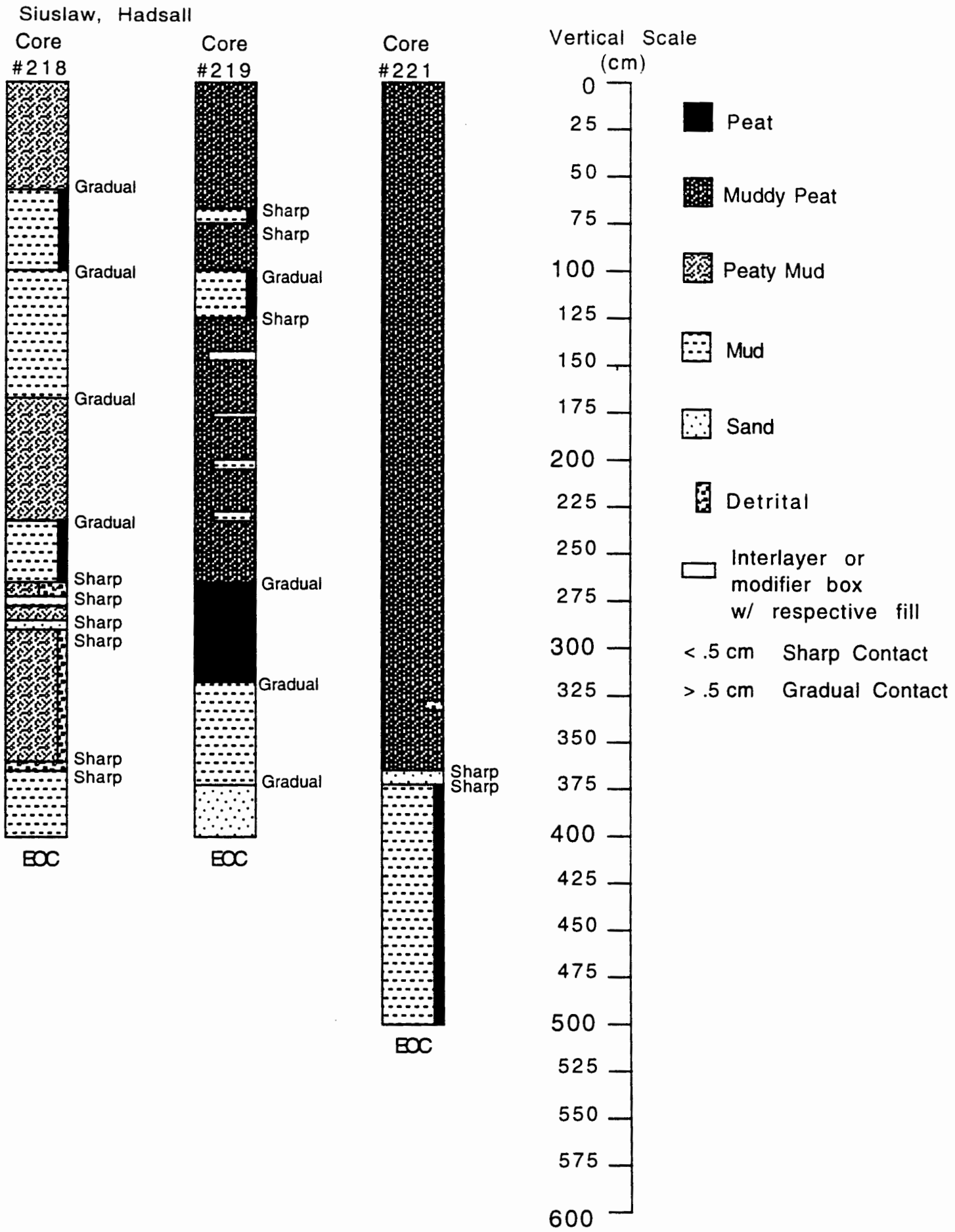
Siuslaw, Demmings (222--PC)
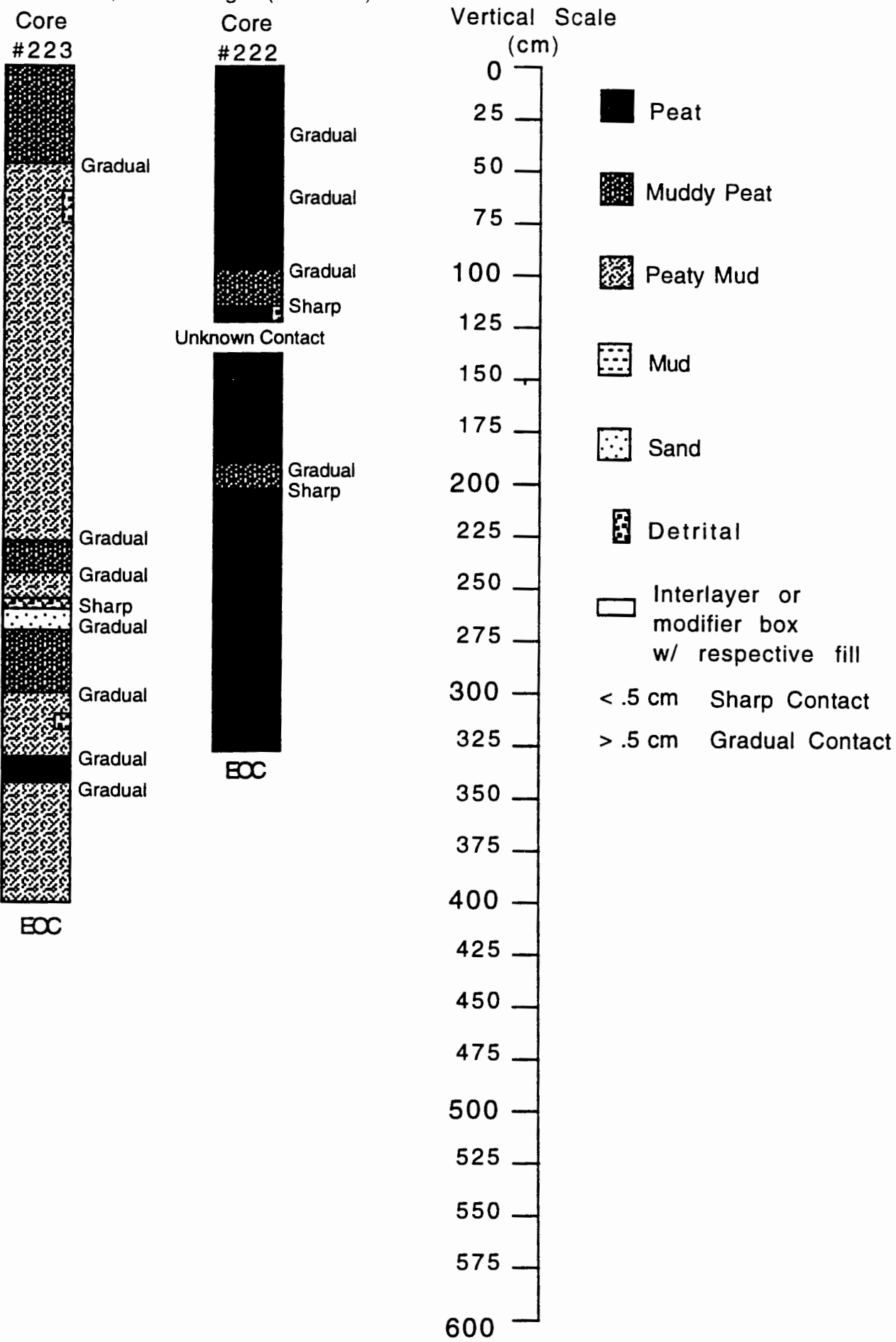
Siuslaw, Lily Lake (225--PC)

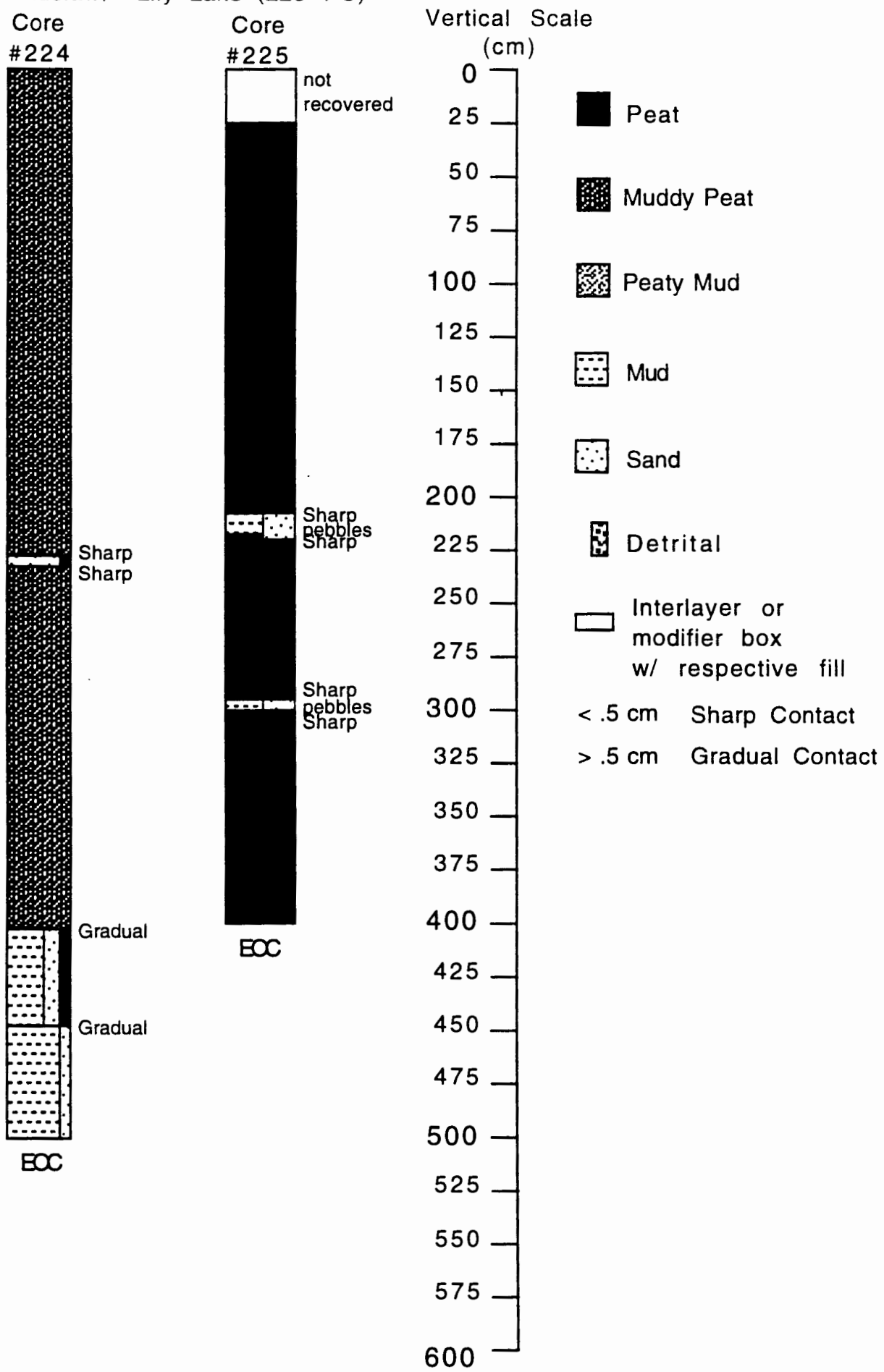



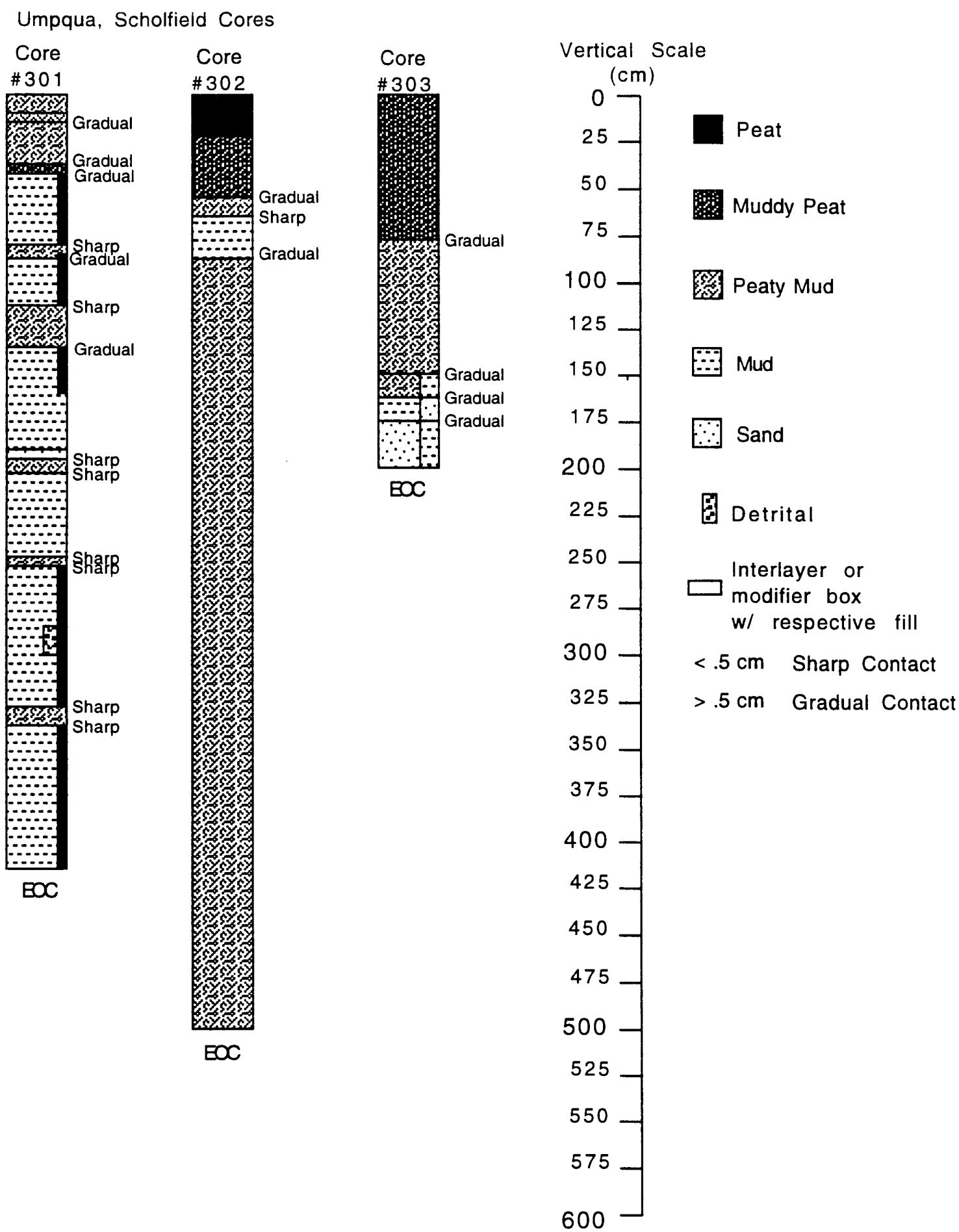

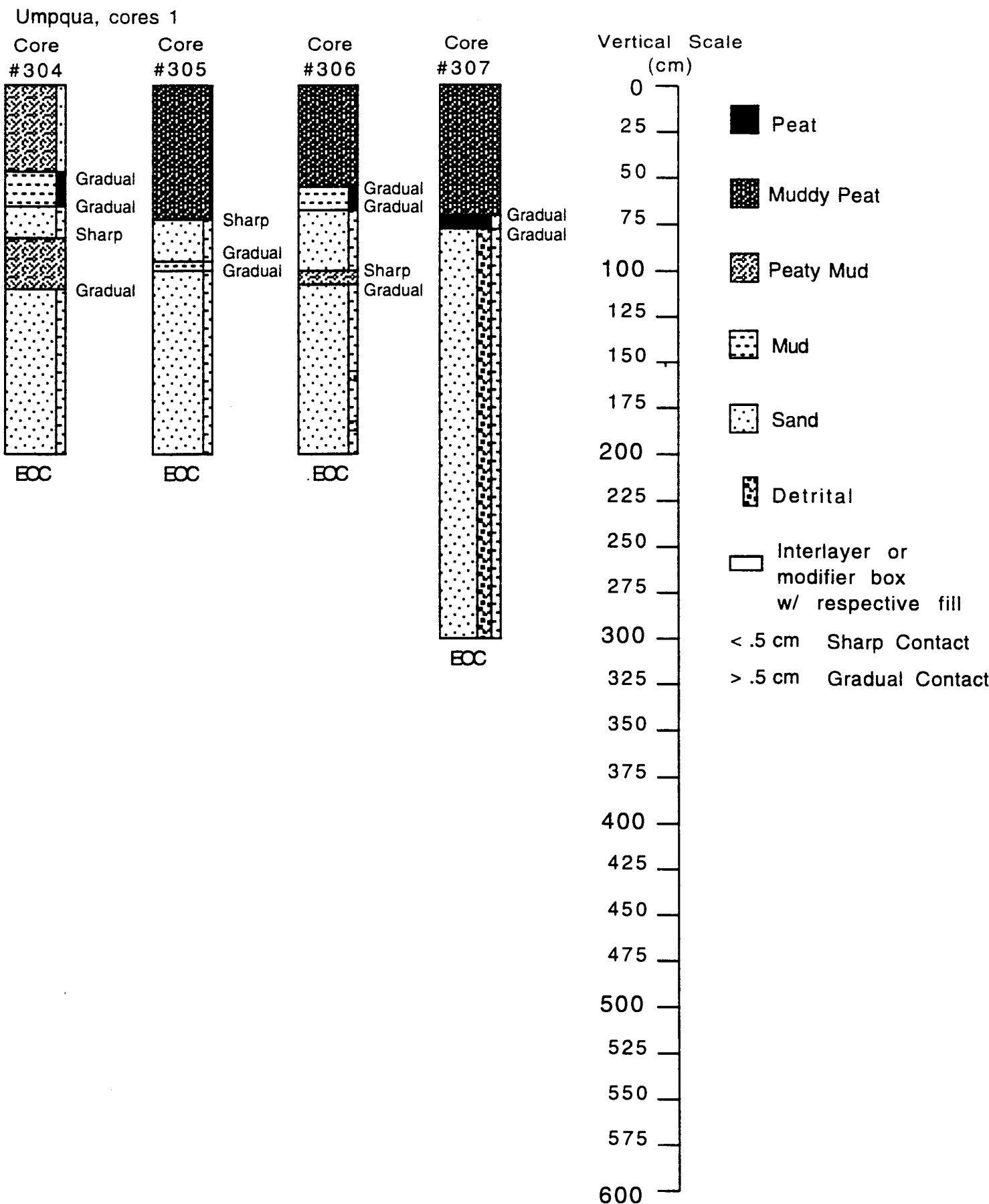
Umpqua, cores 2

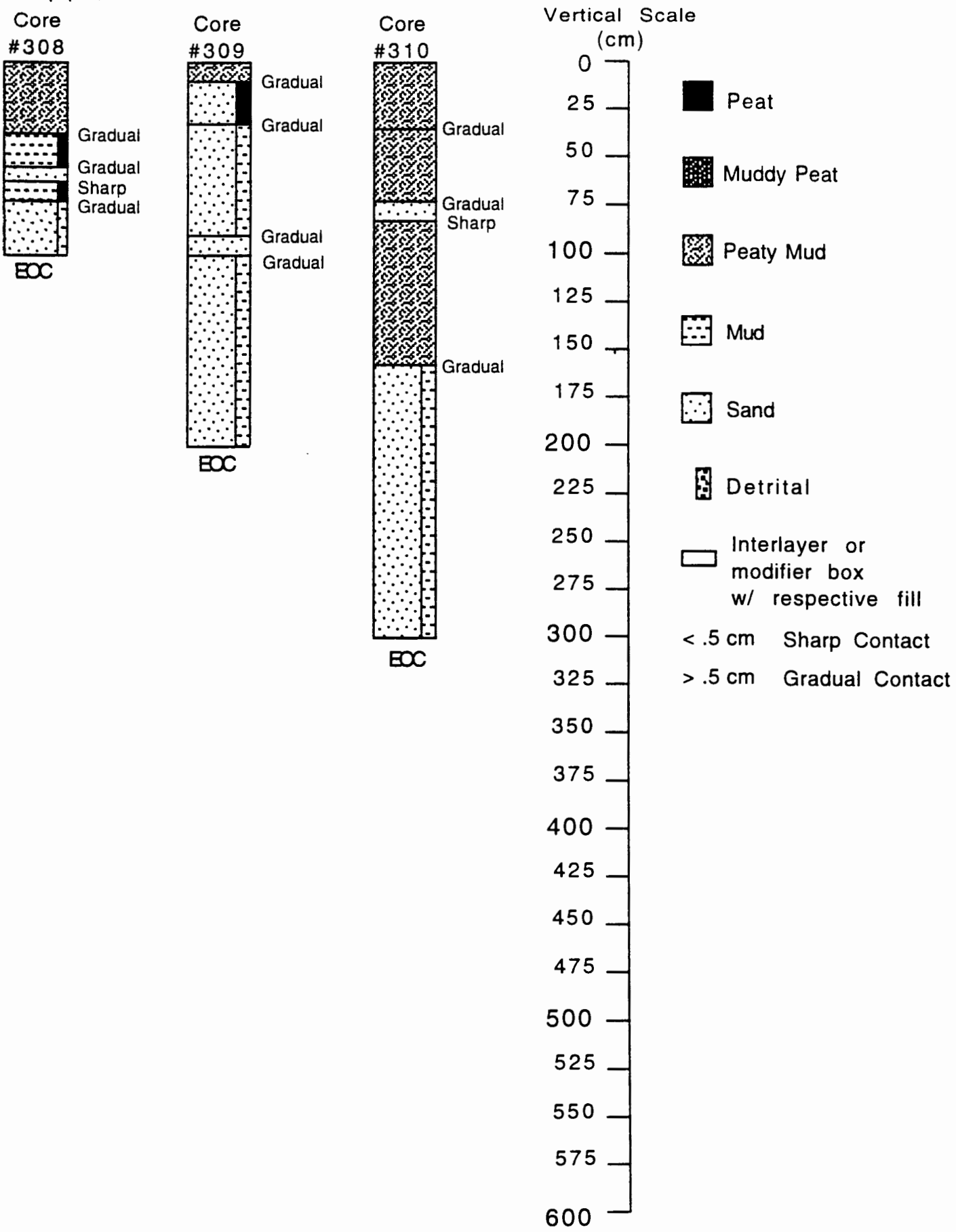



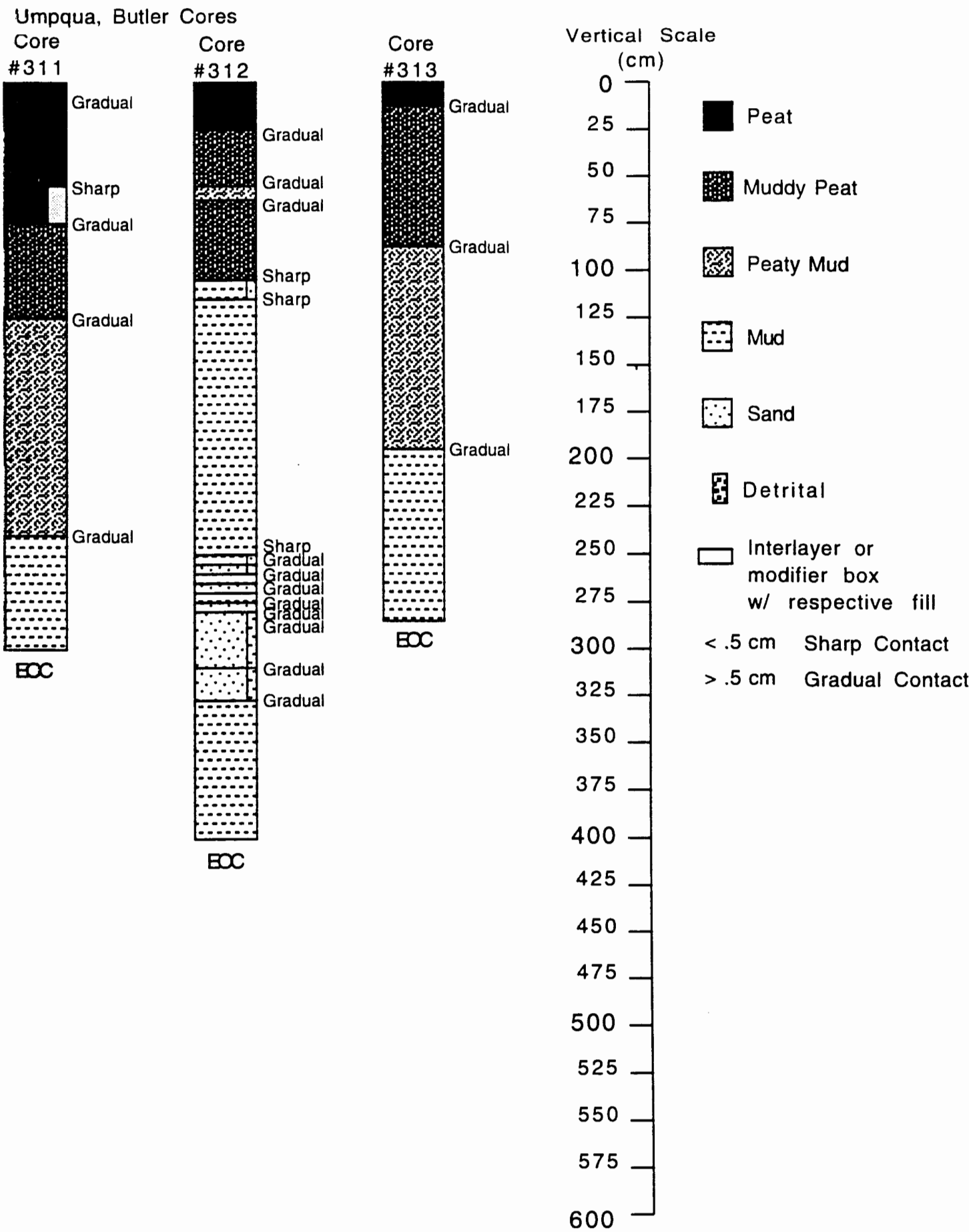

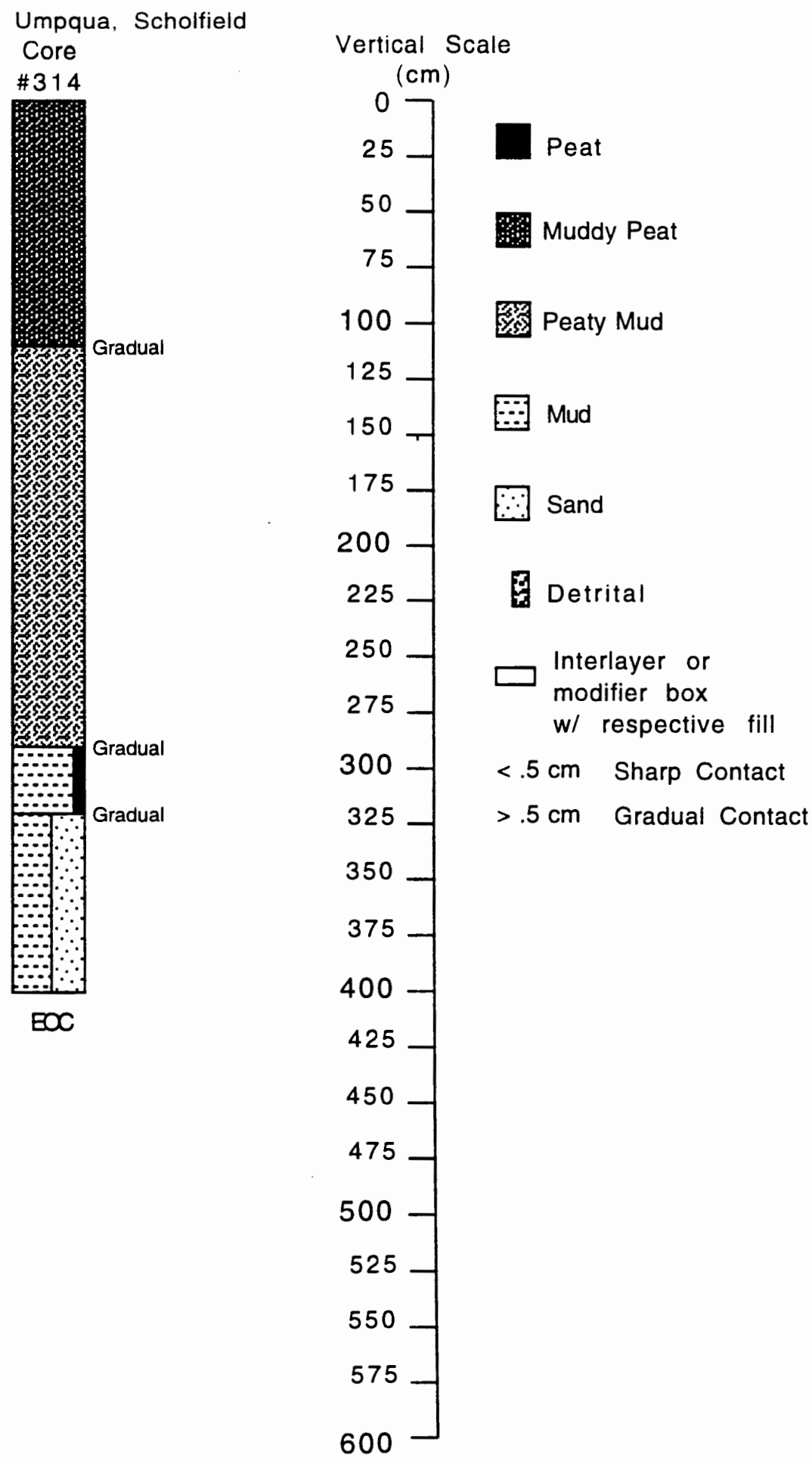

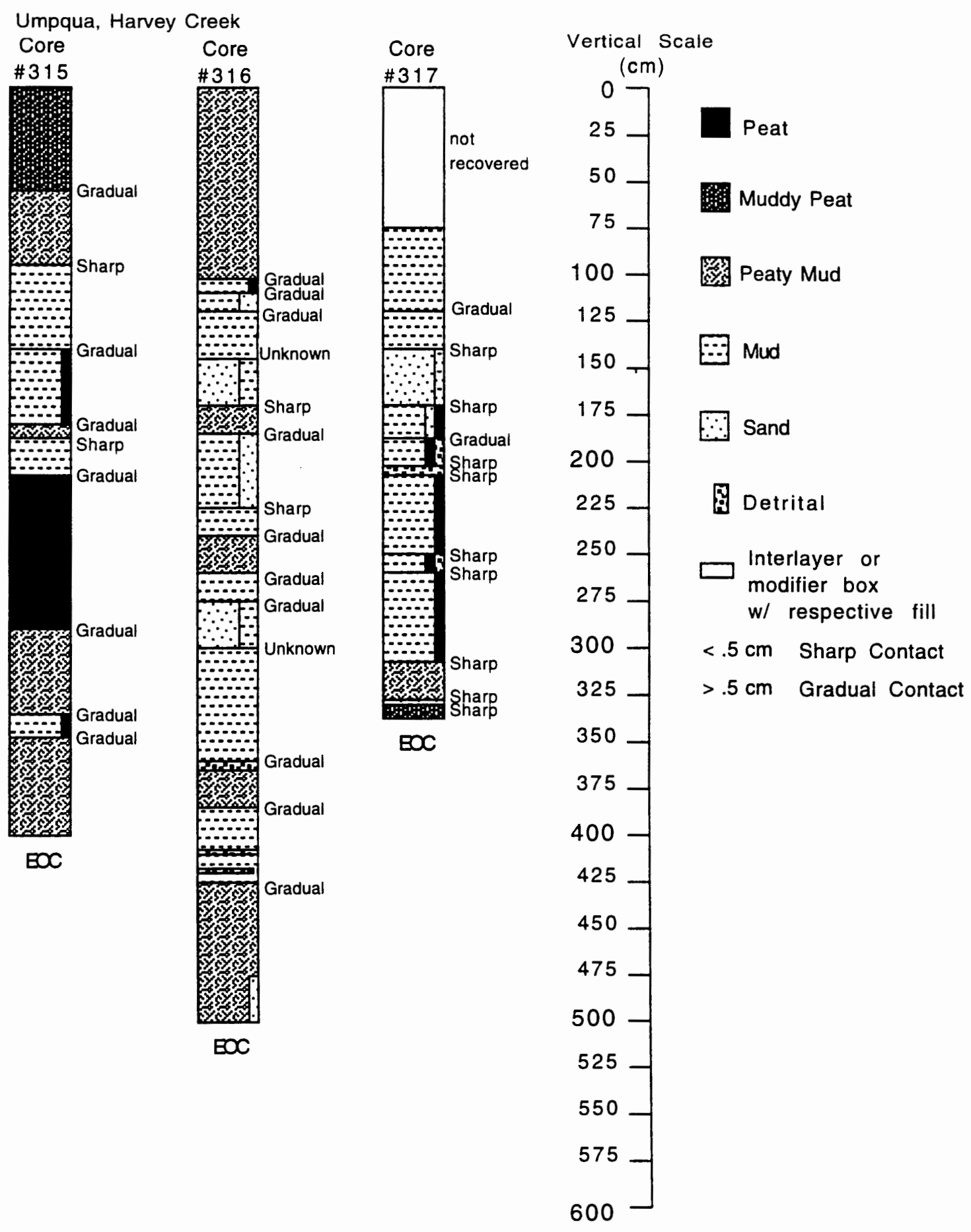

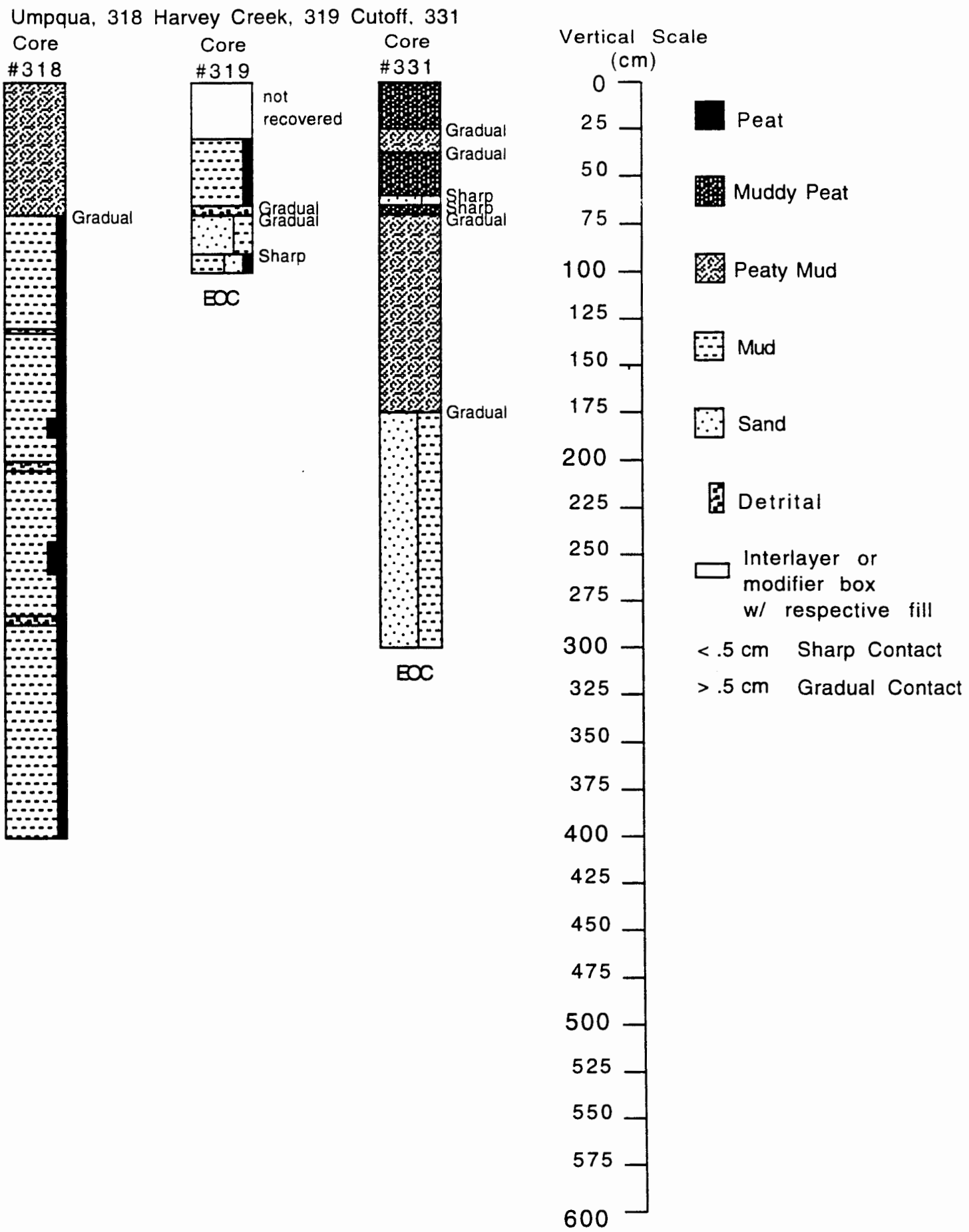
Umpqua, Oar Creek

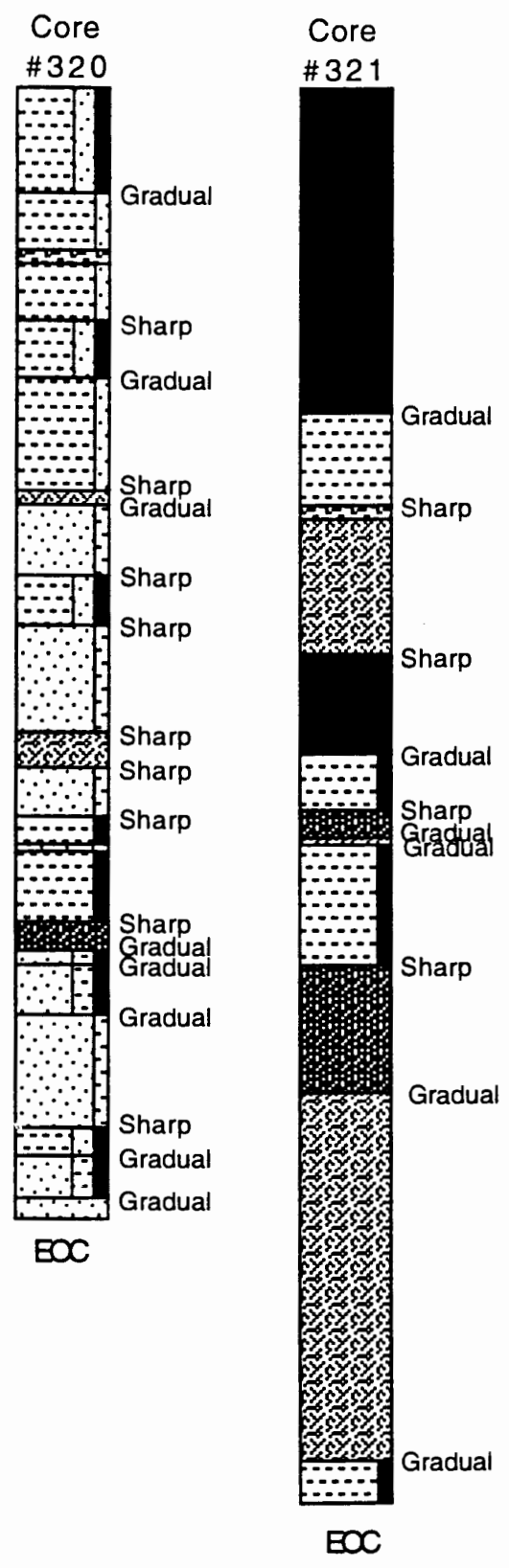

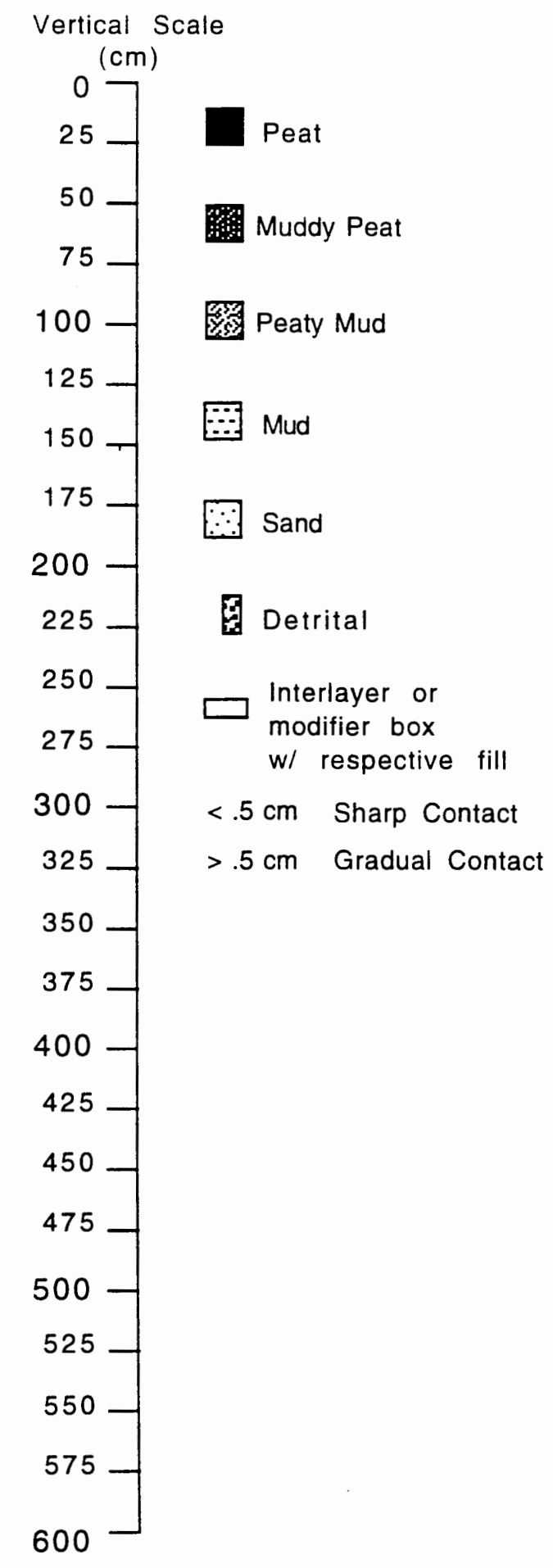



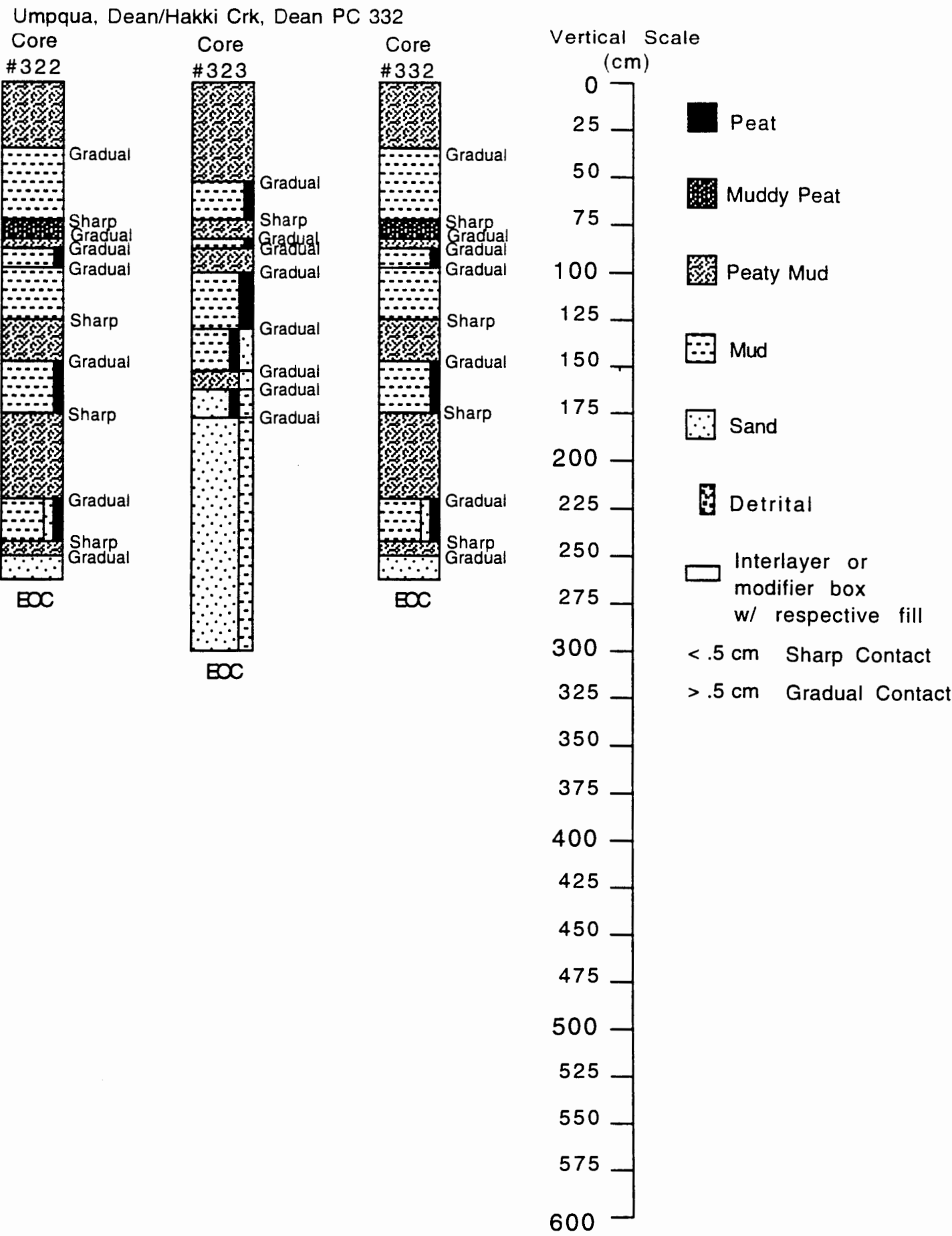
Umpqua, Smith

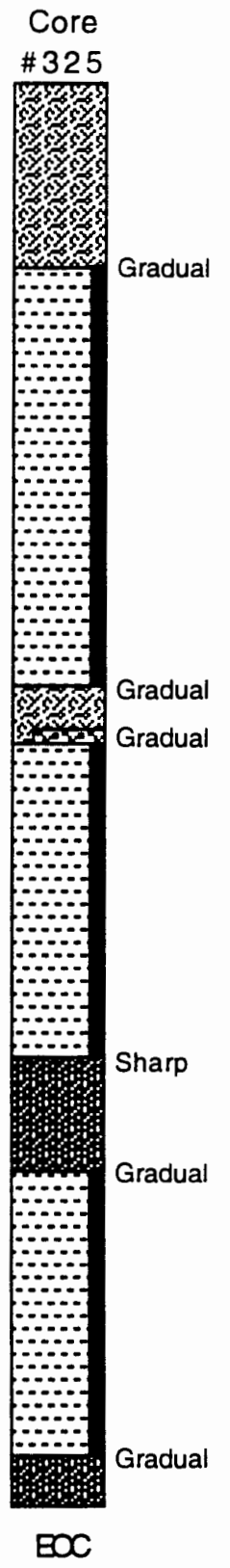

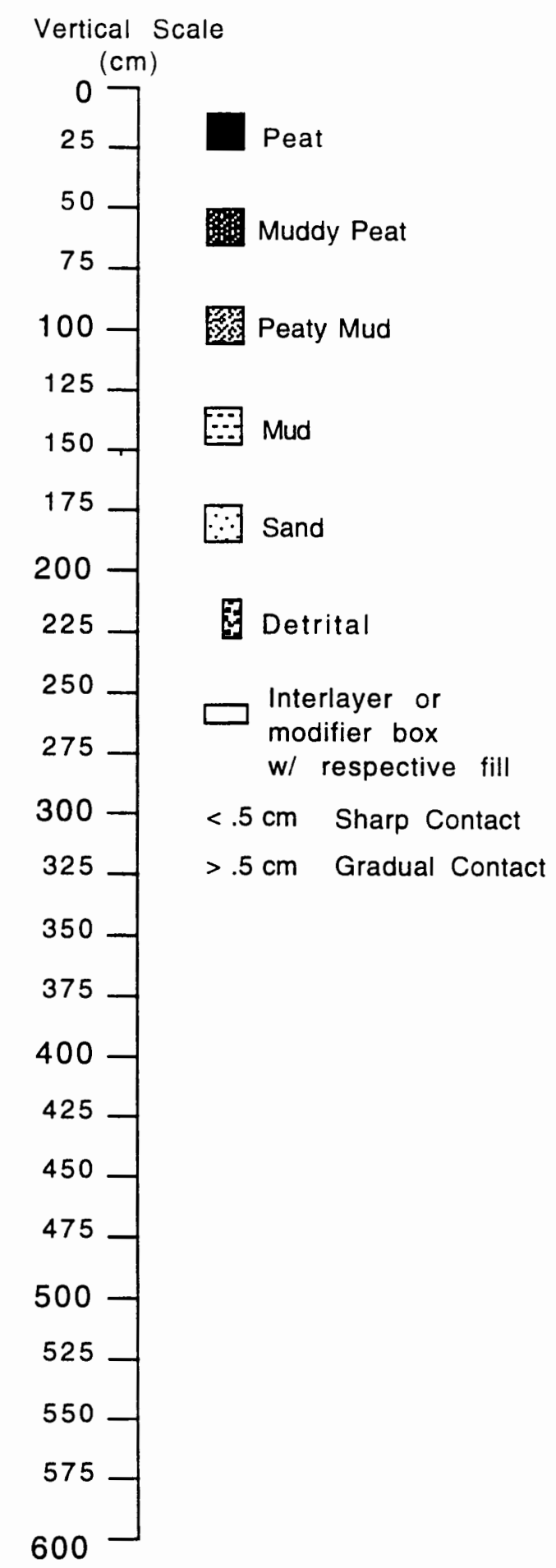



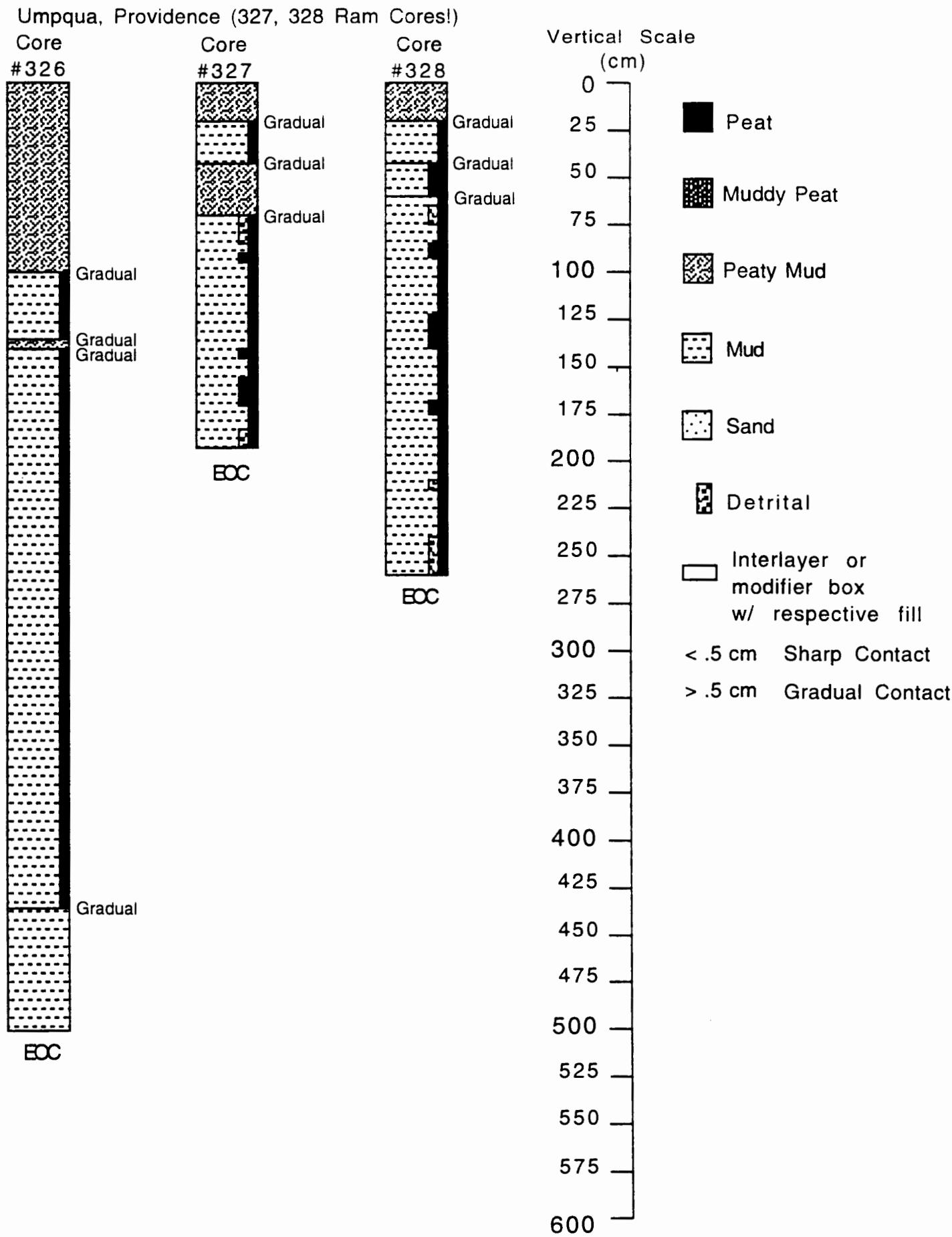

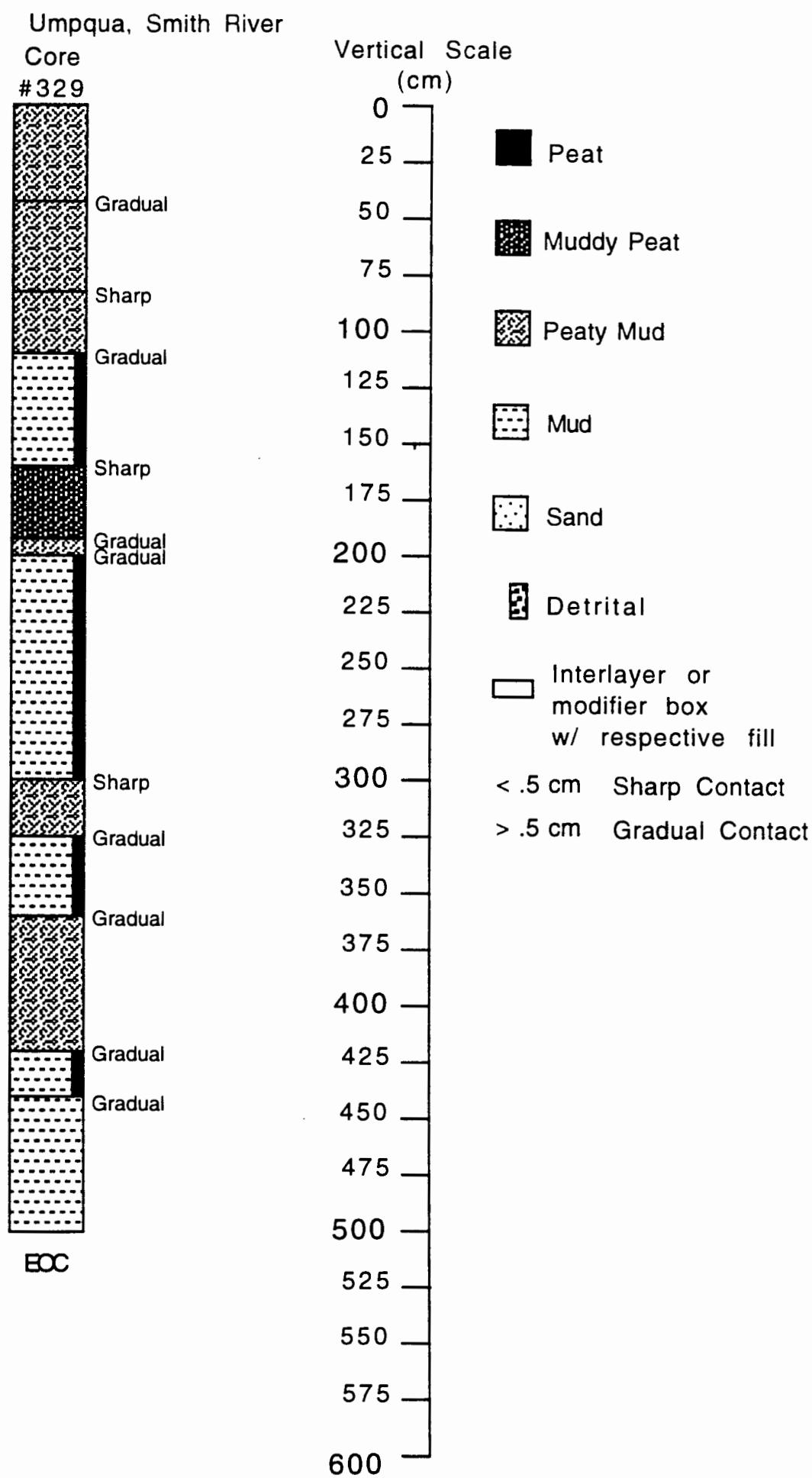
Umpqua, Ram Cores! (Pound Cores), Cutoff, Butler Ck., Otter $\mathrm{Ck}$

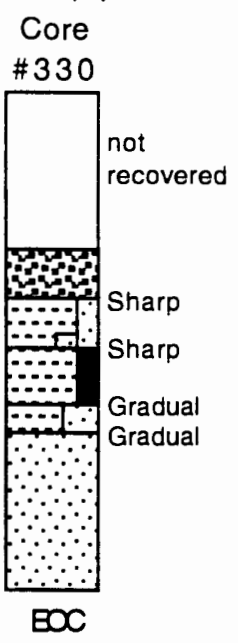

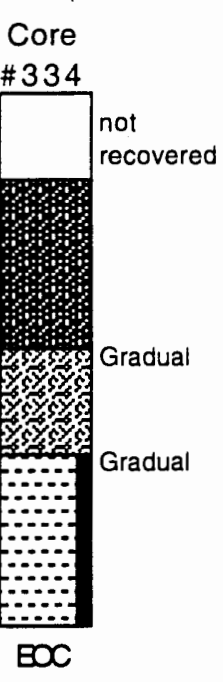

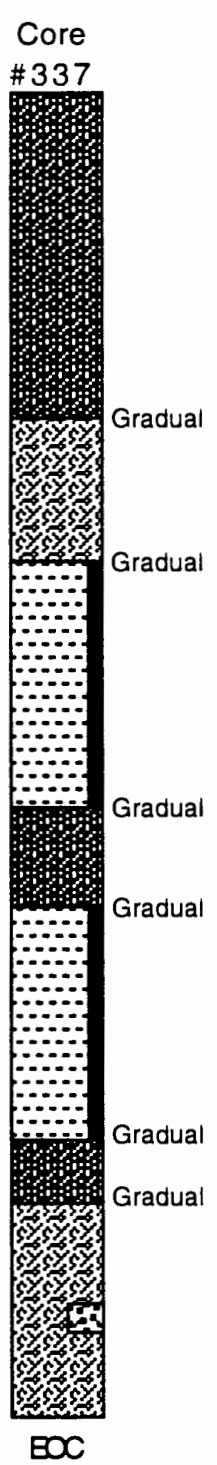

Vertical Scale 

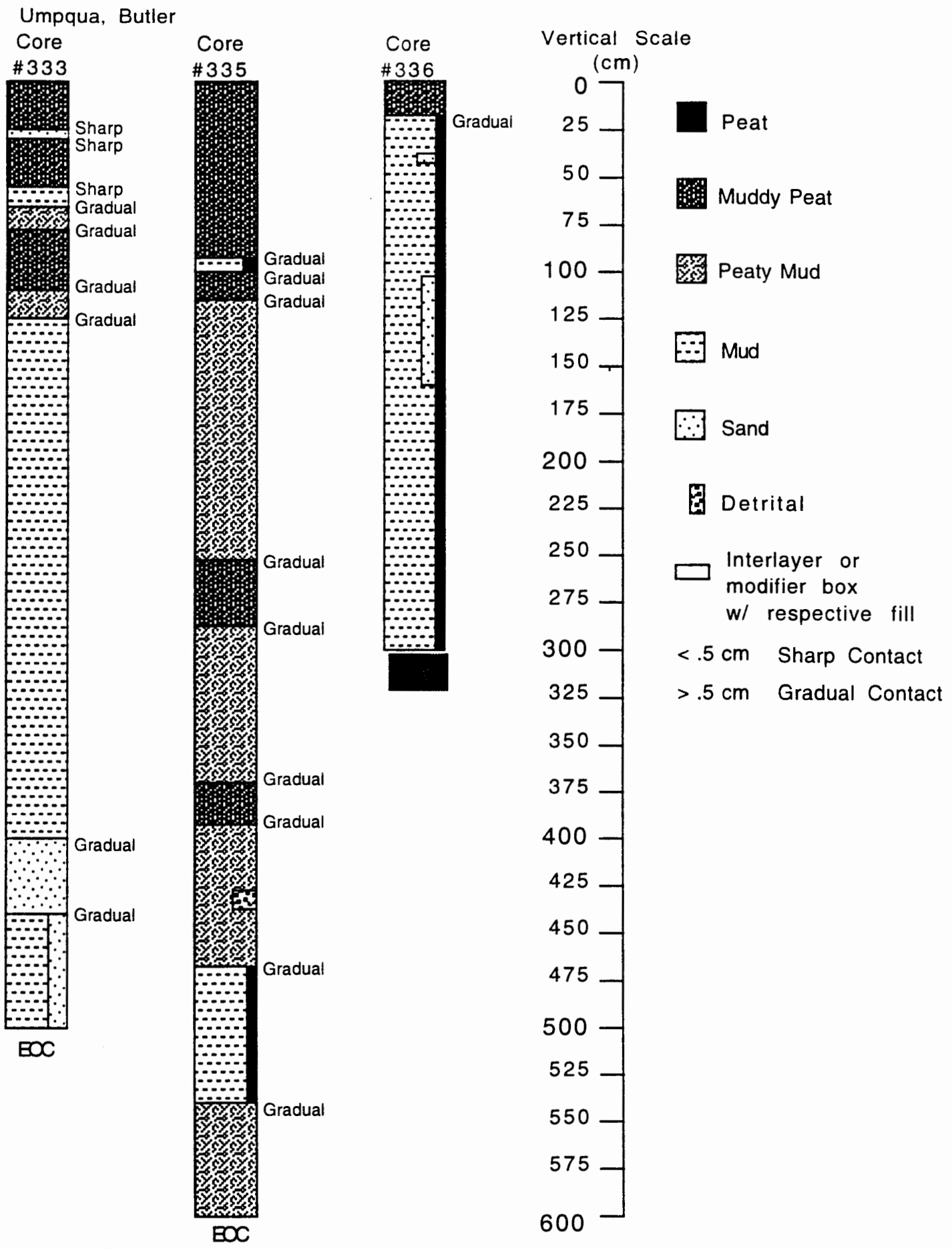

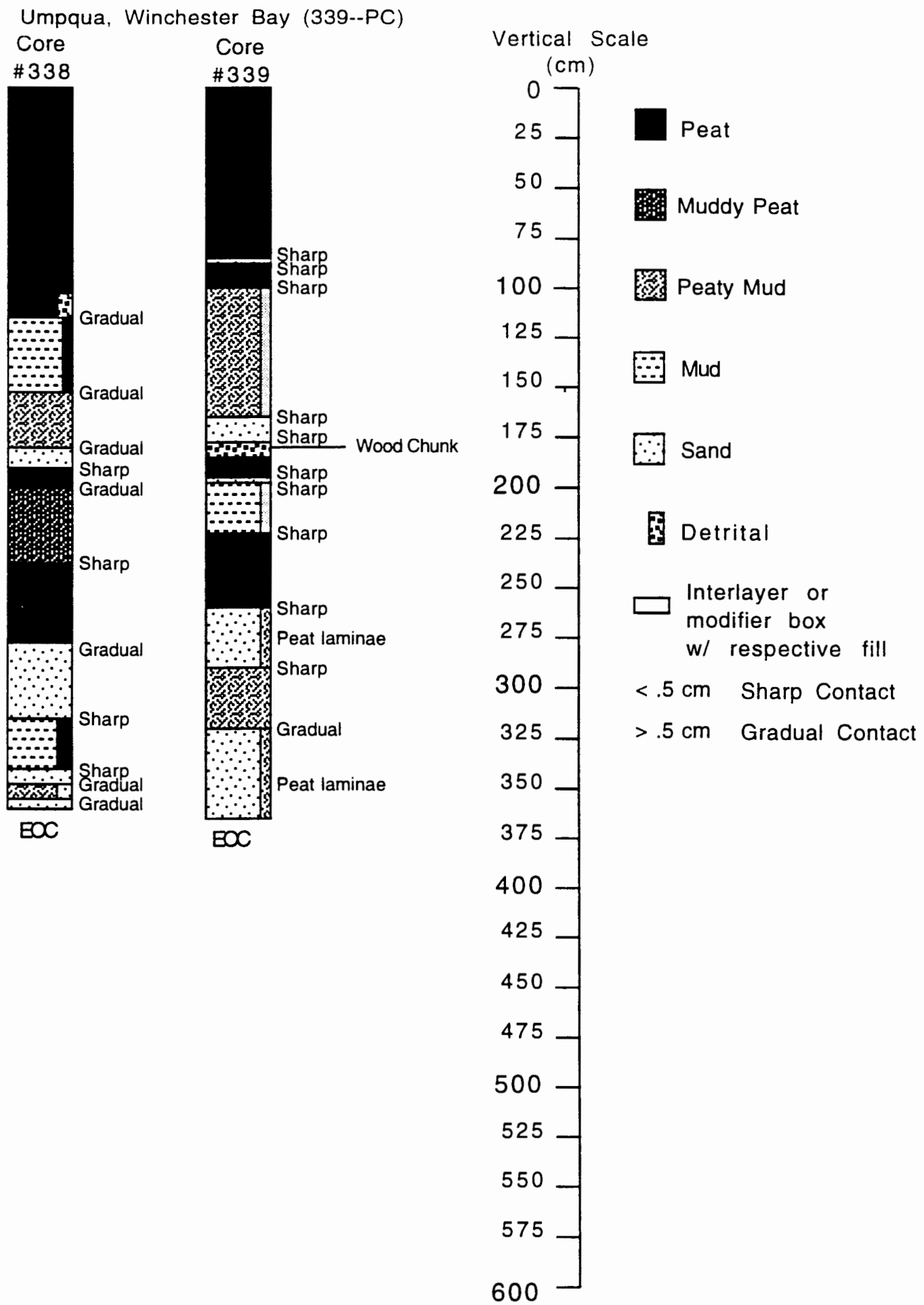

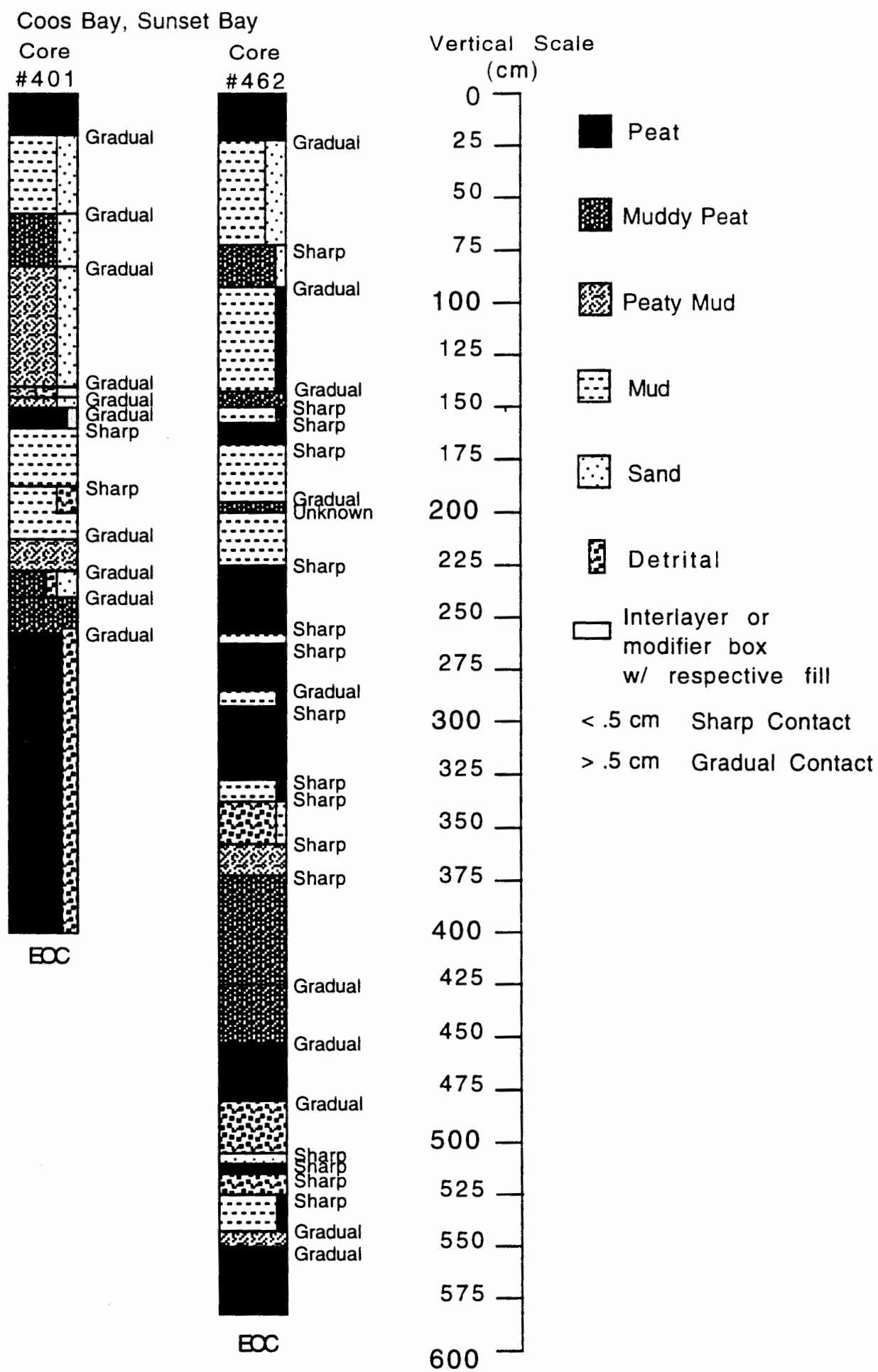
Coos Bay Cores 1

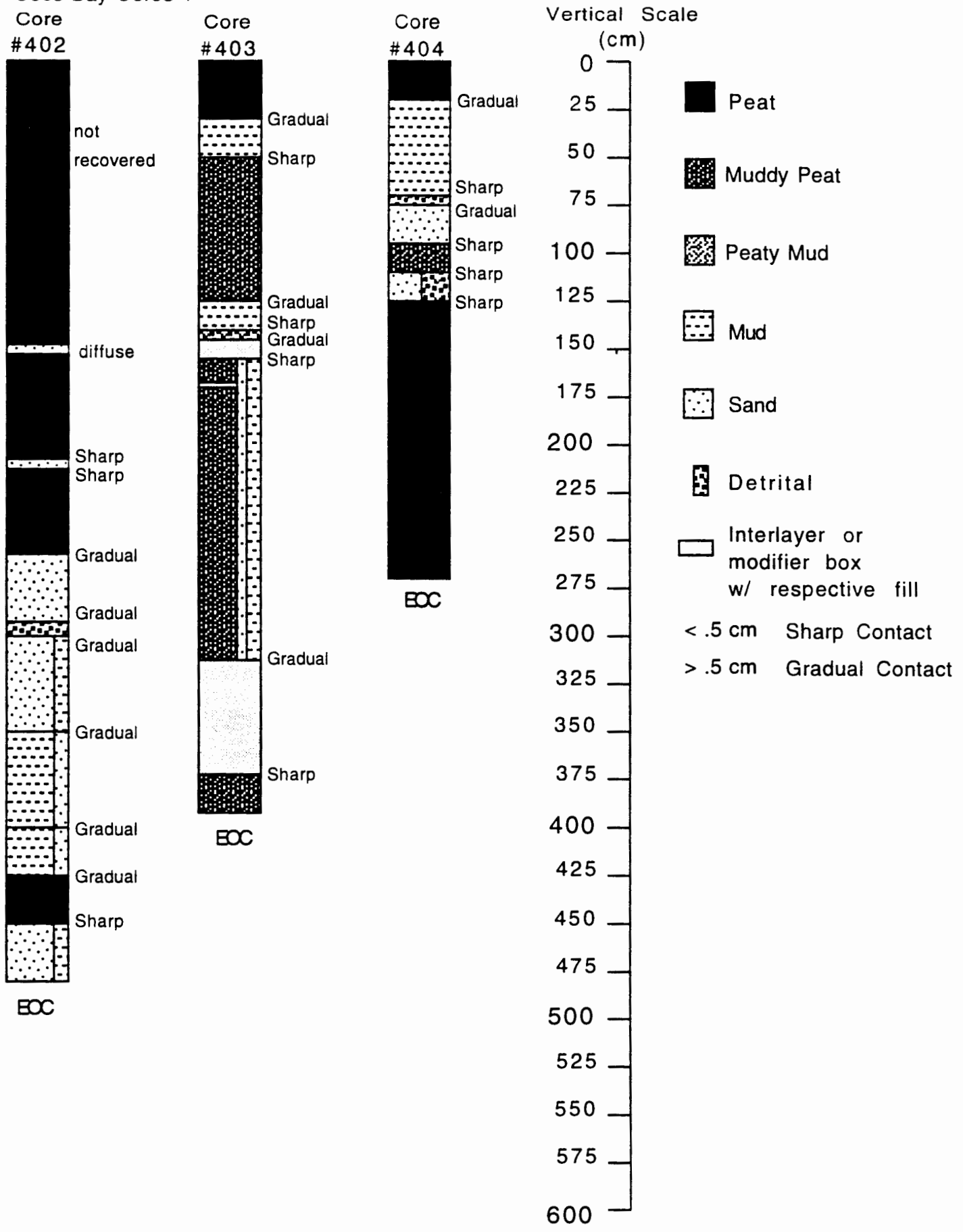


Coos Bay, S Fork, Coos River Cores 2
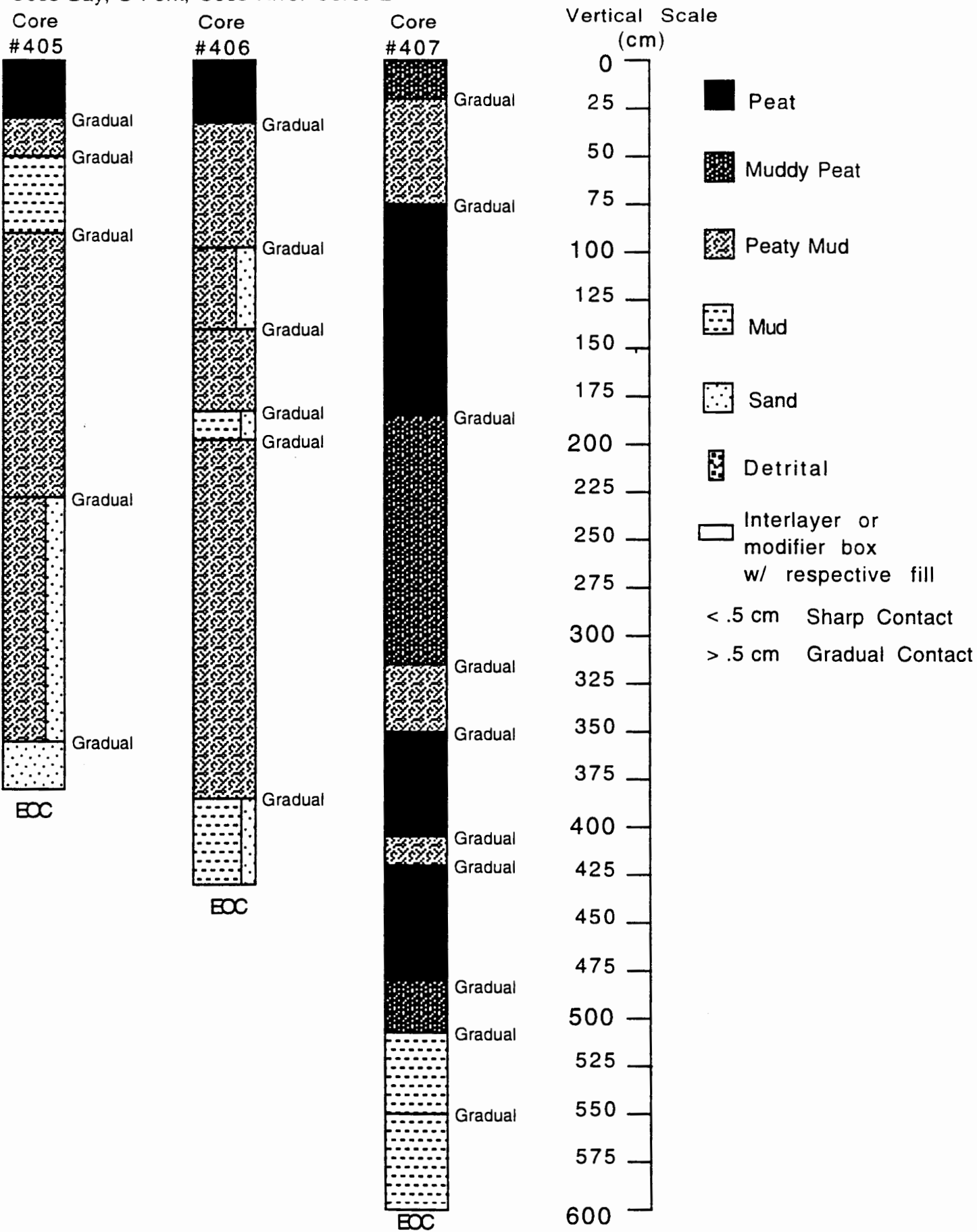
Coos Bay, South Slough Cores

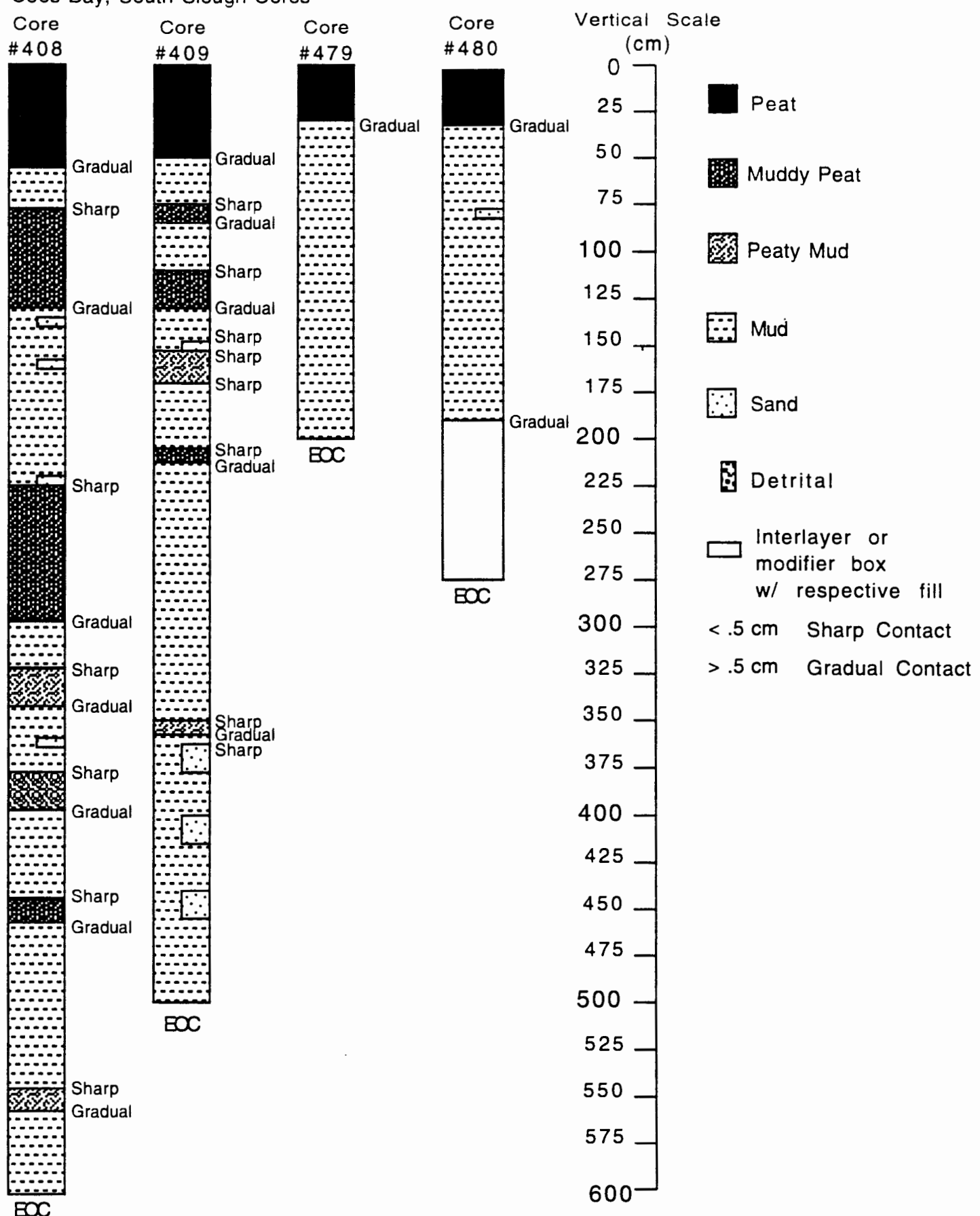



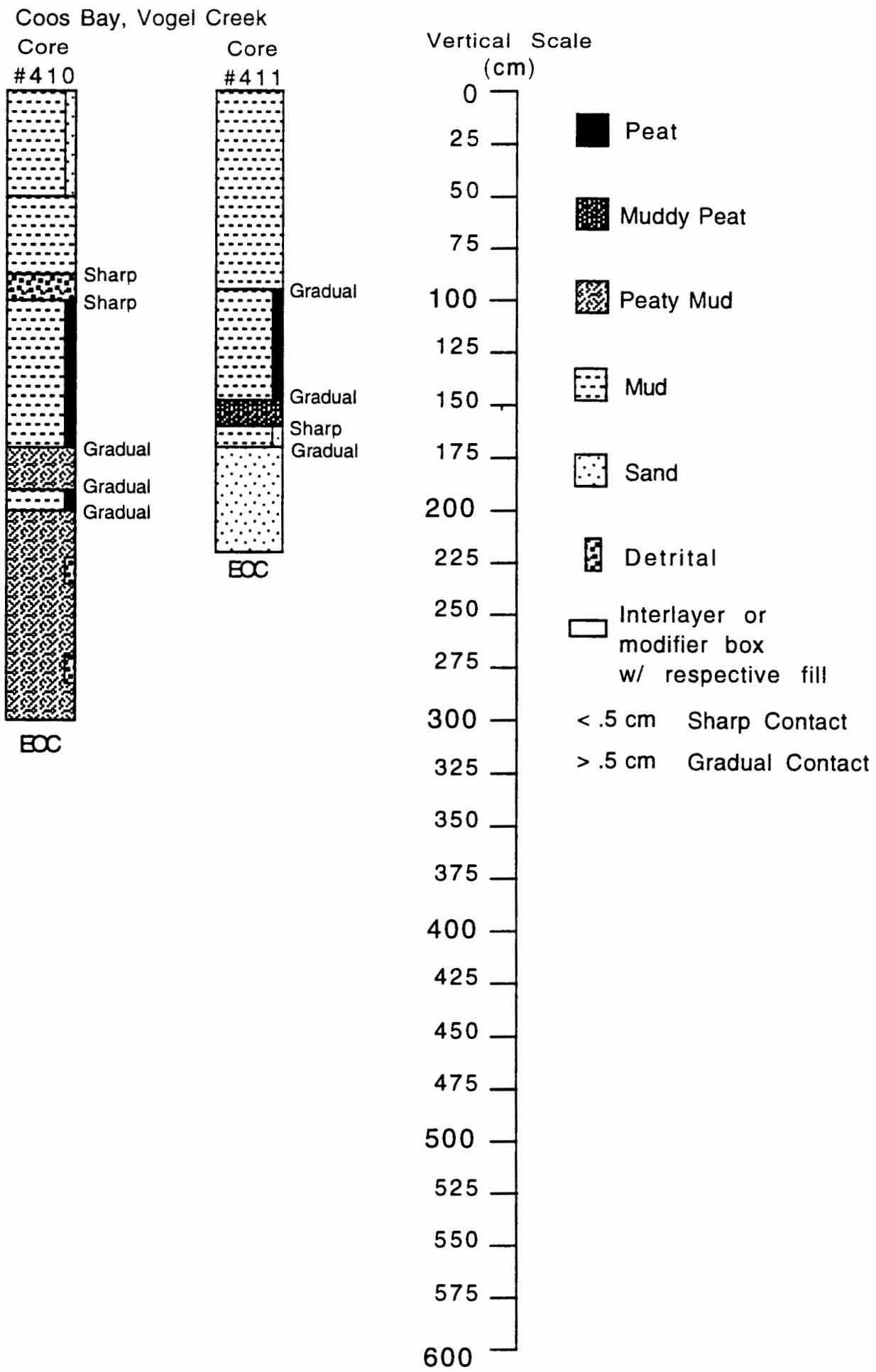


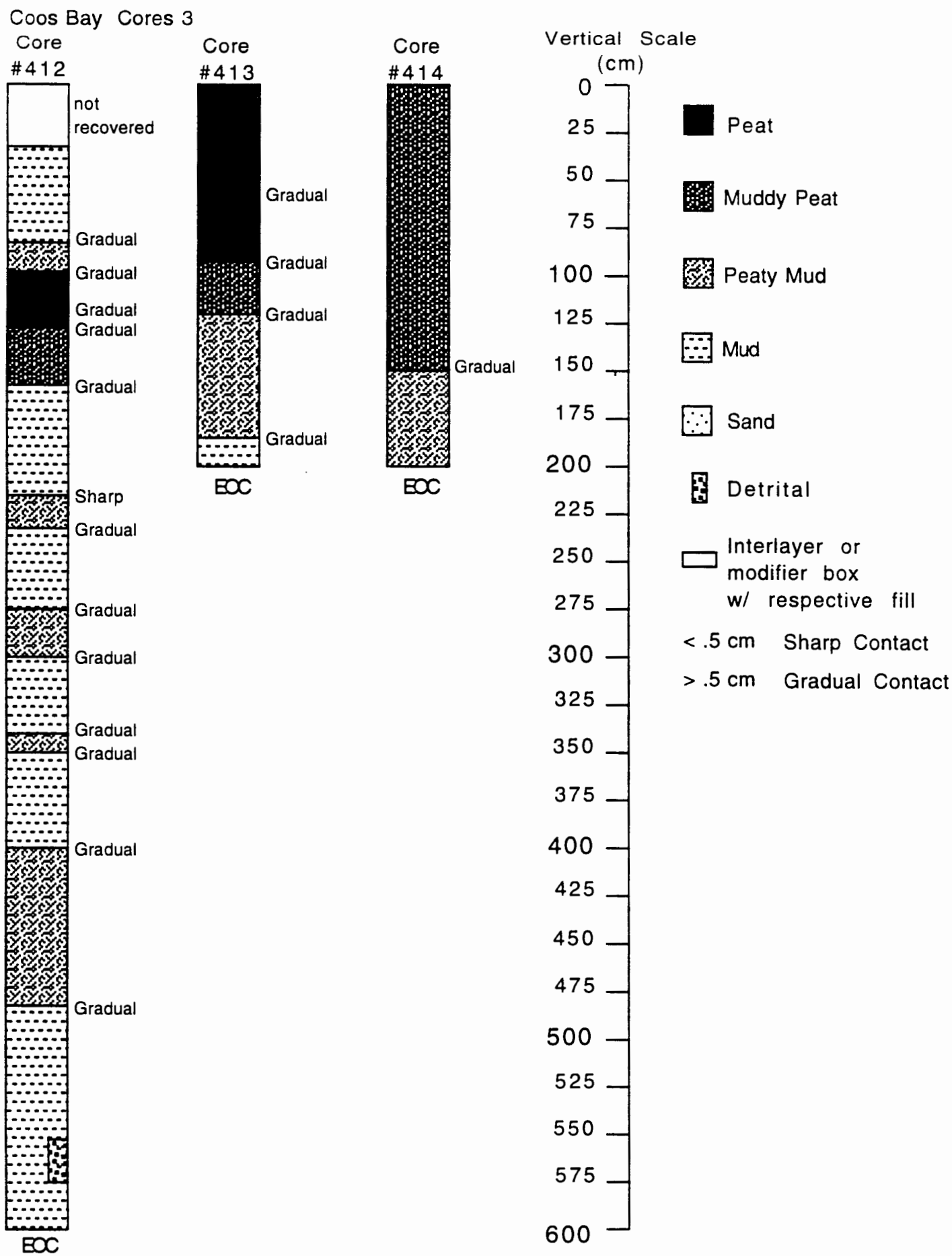



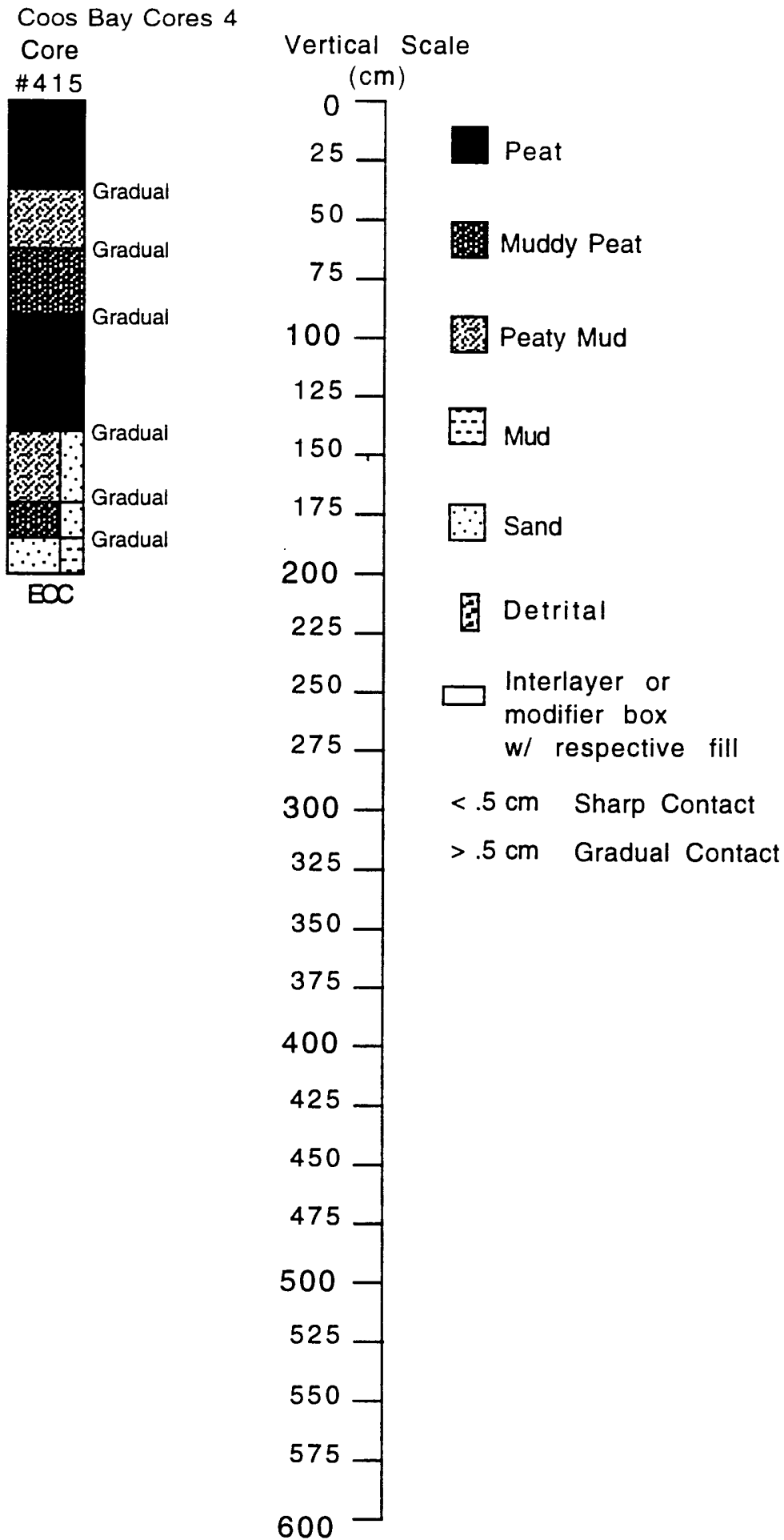

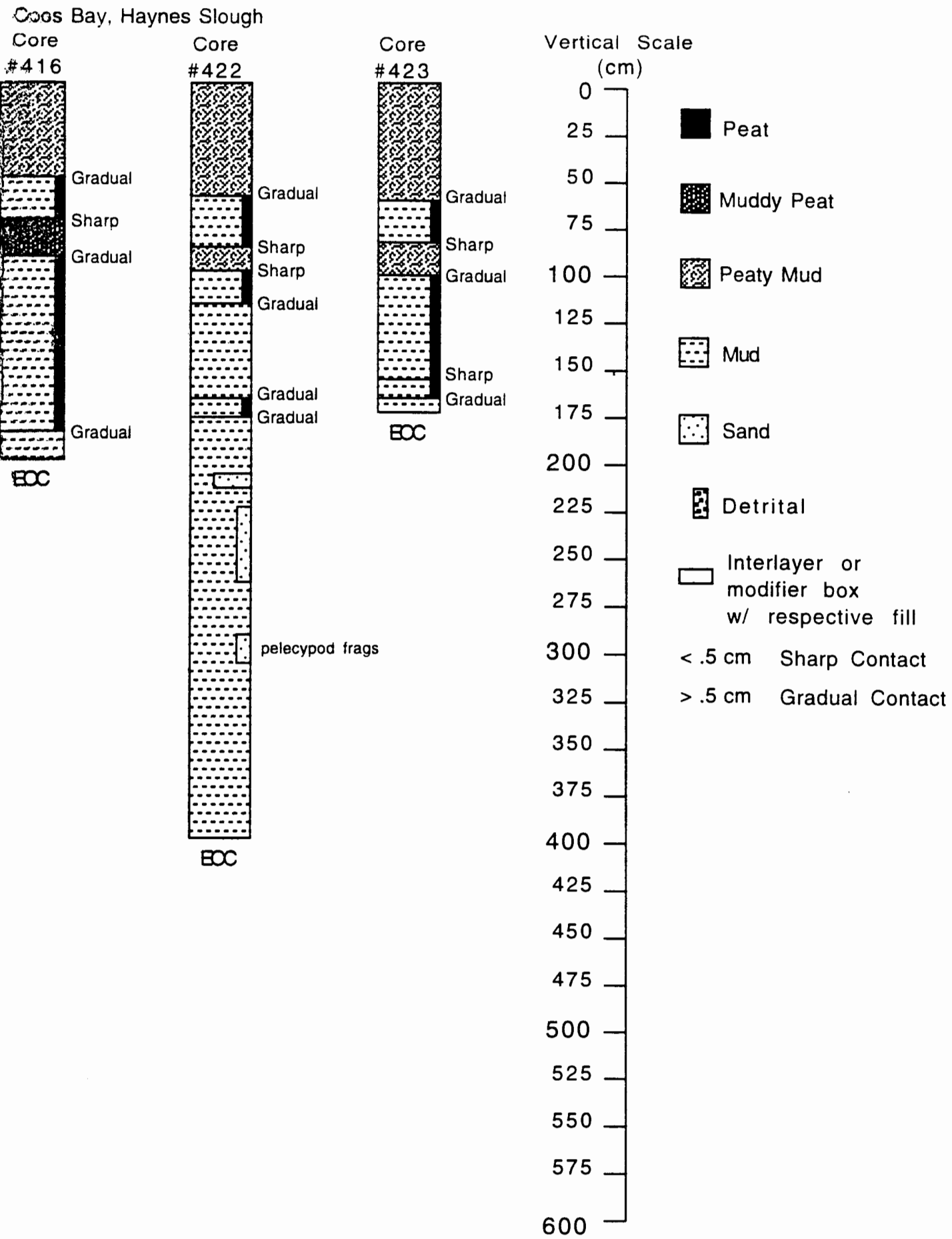
Coos Bay, Palouse

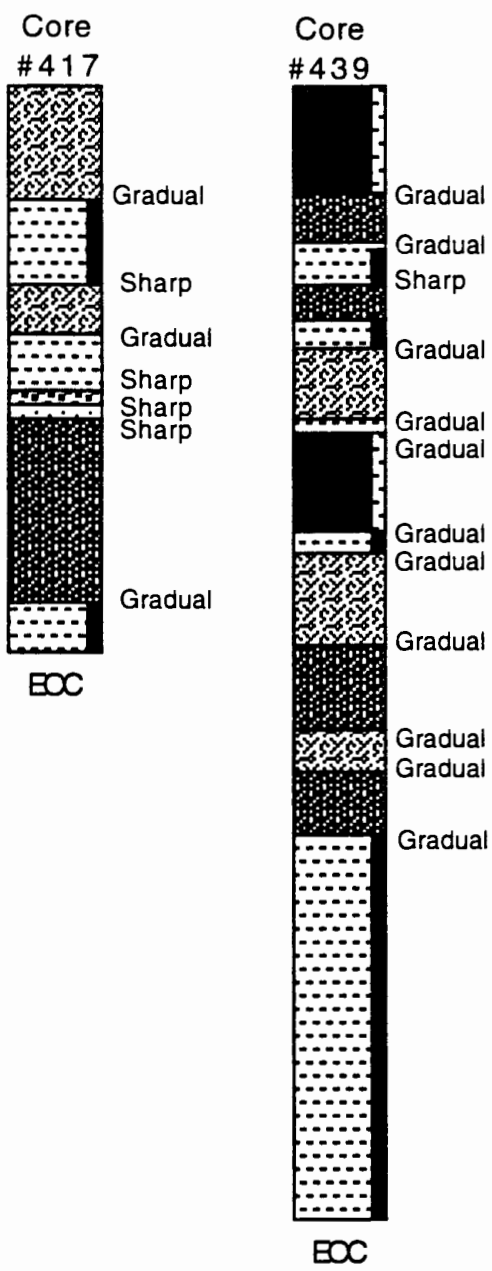

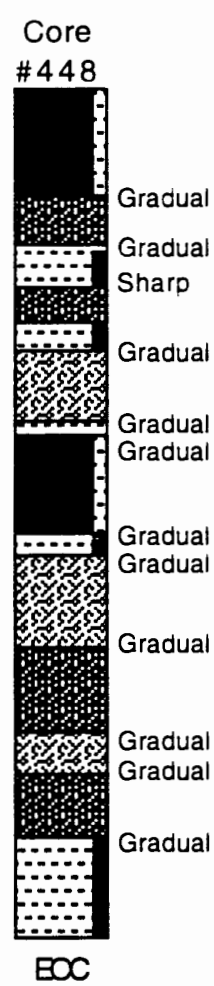

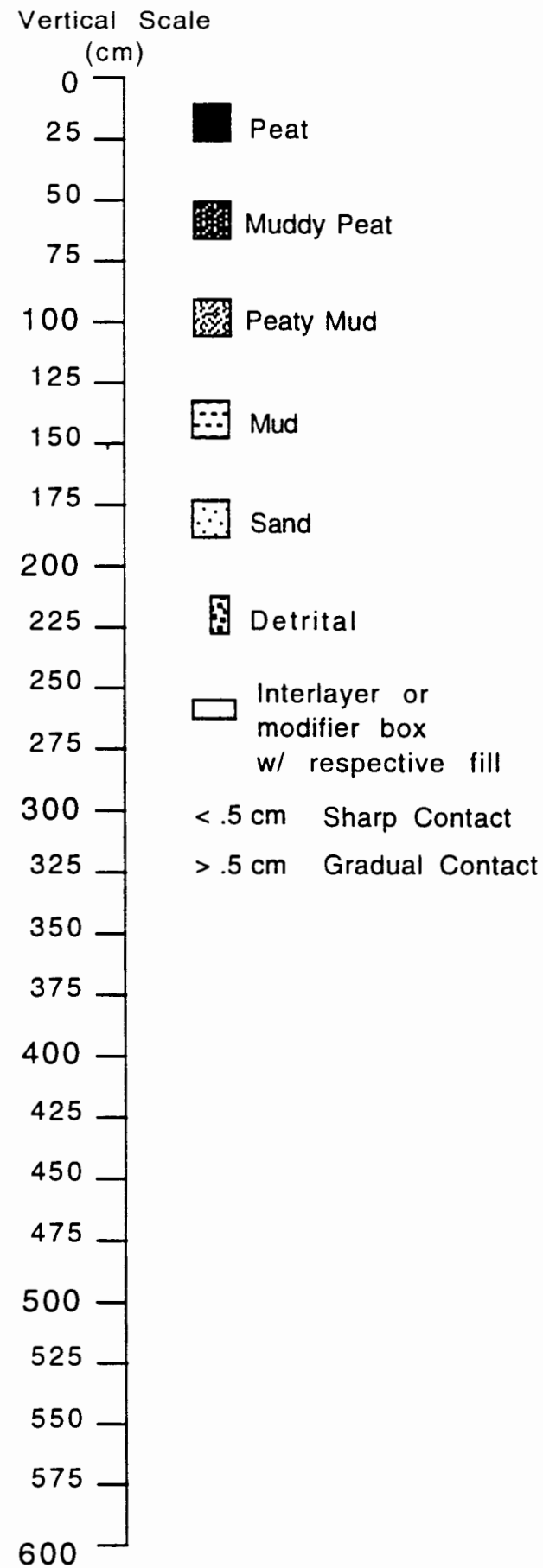




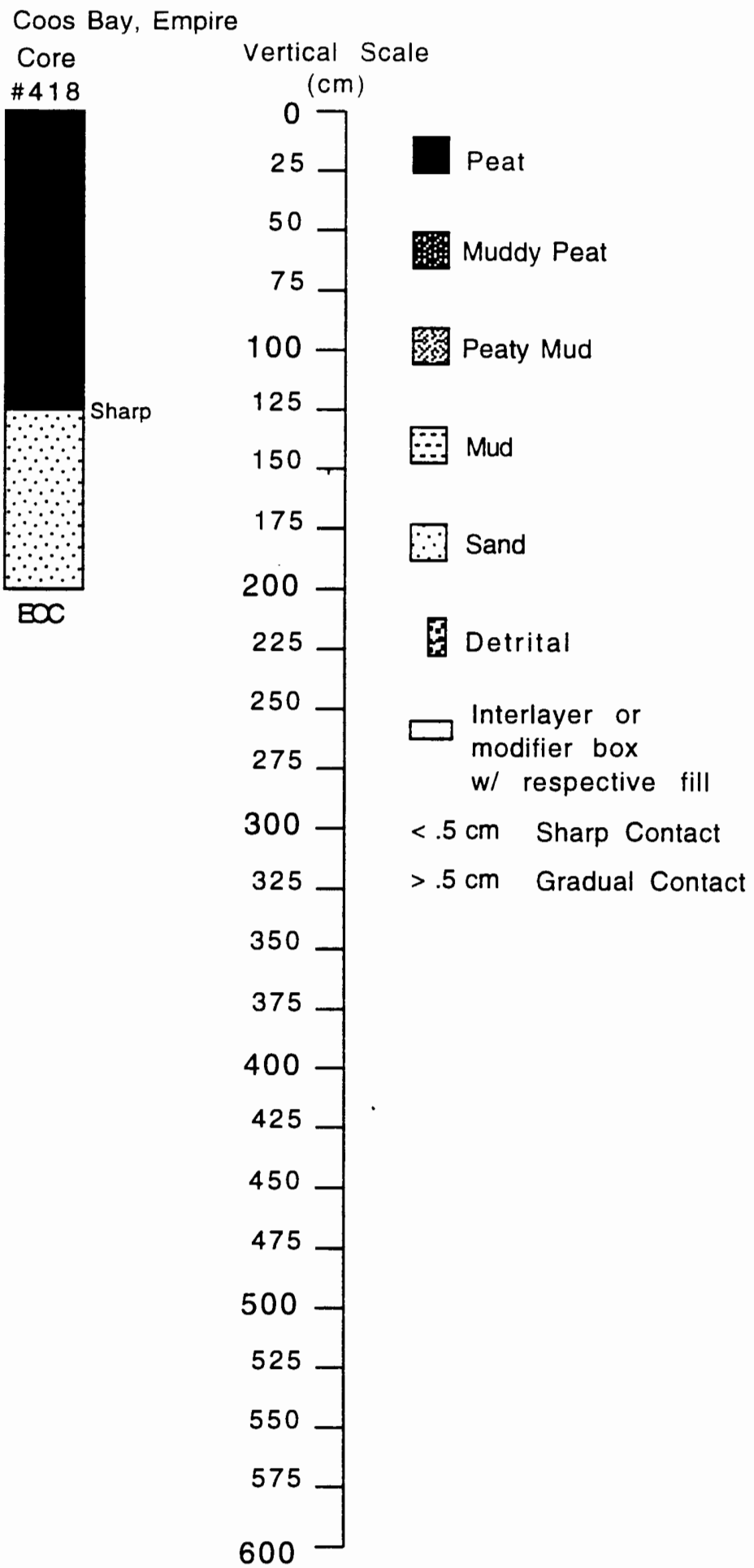




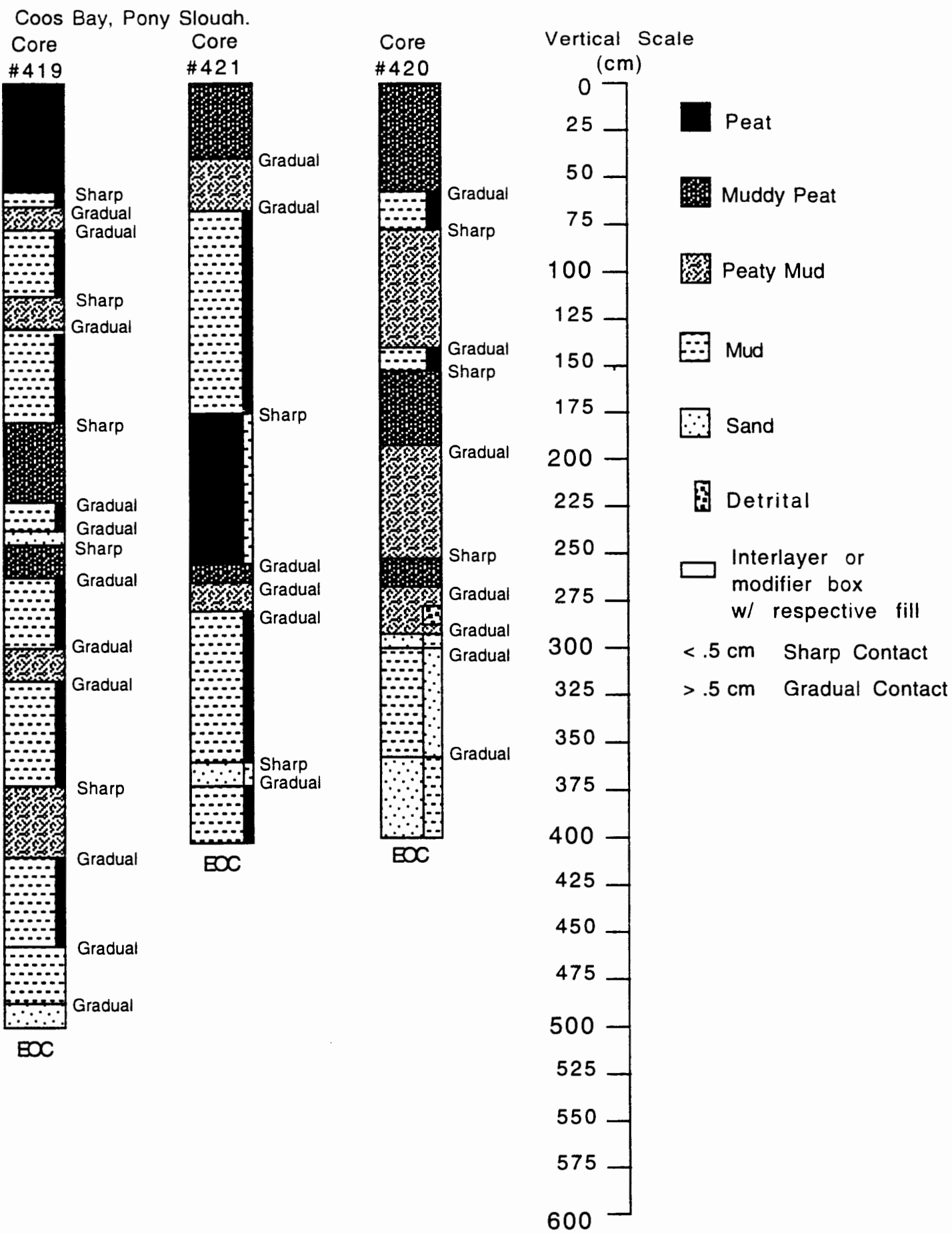


Coos Bay, Palouse Slough

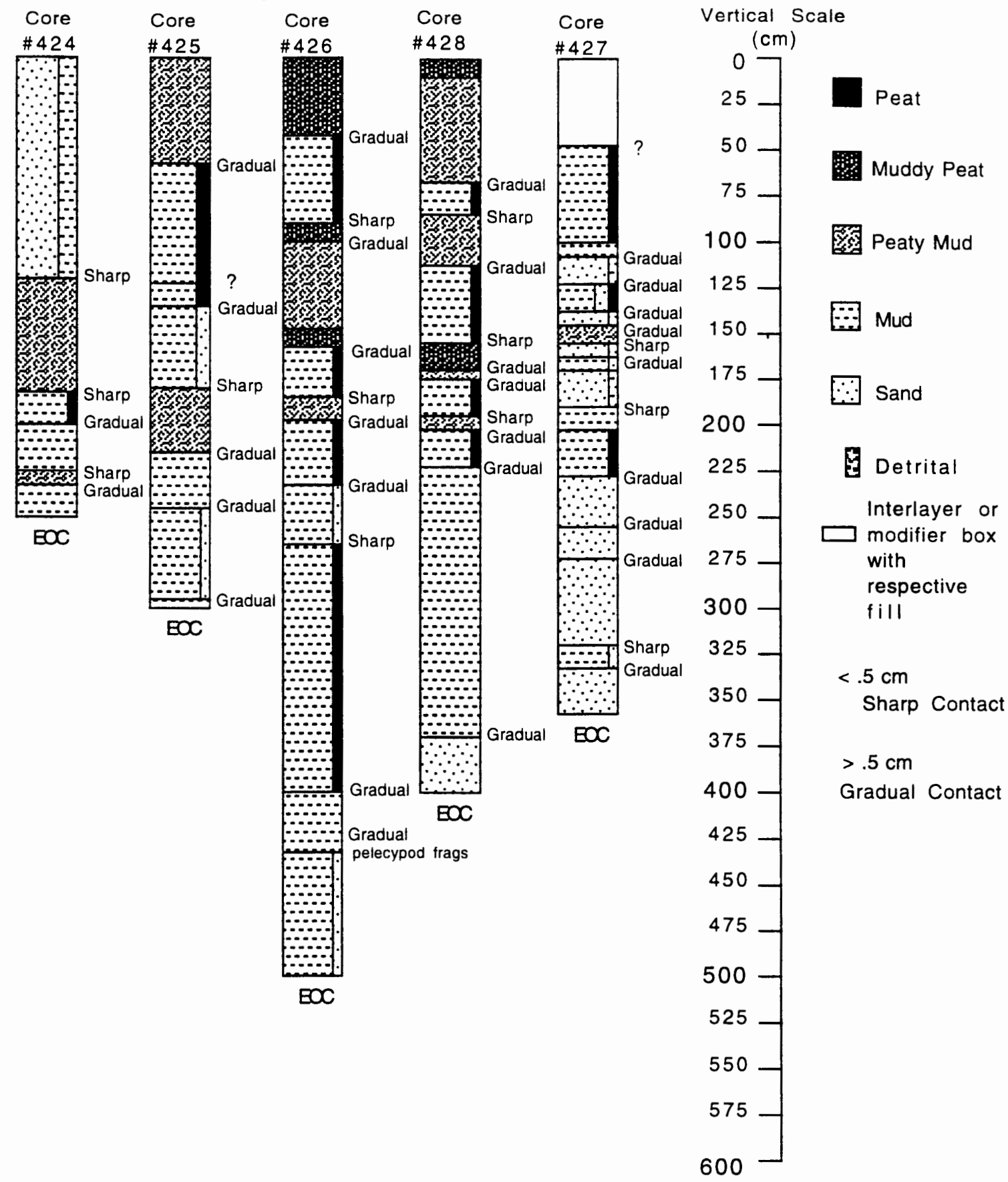


Coos Bay, North Slough

Core

\#431

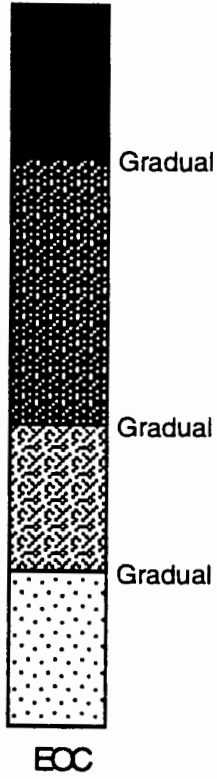

Vertical Scale

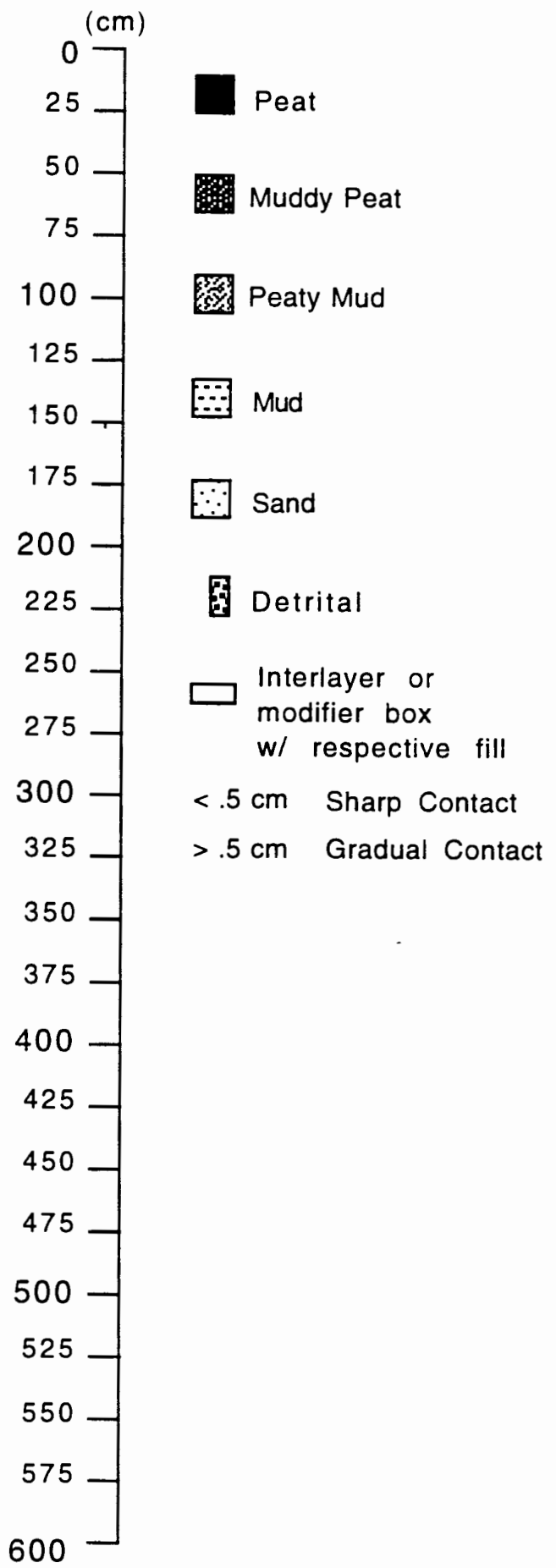




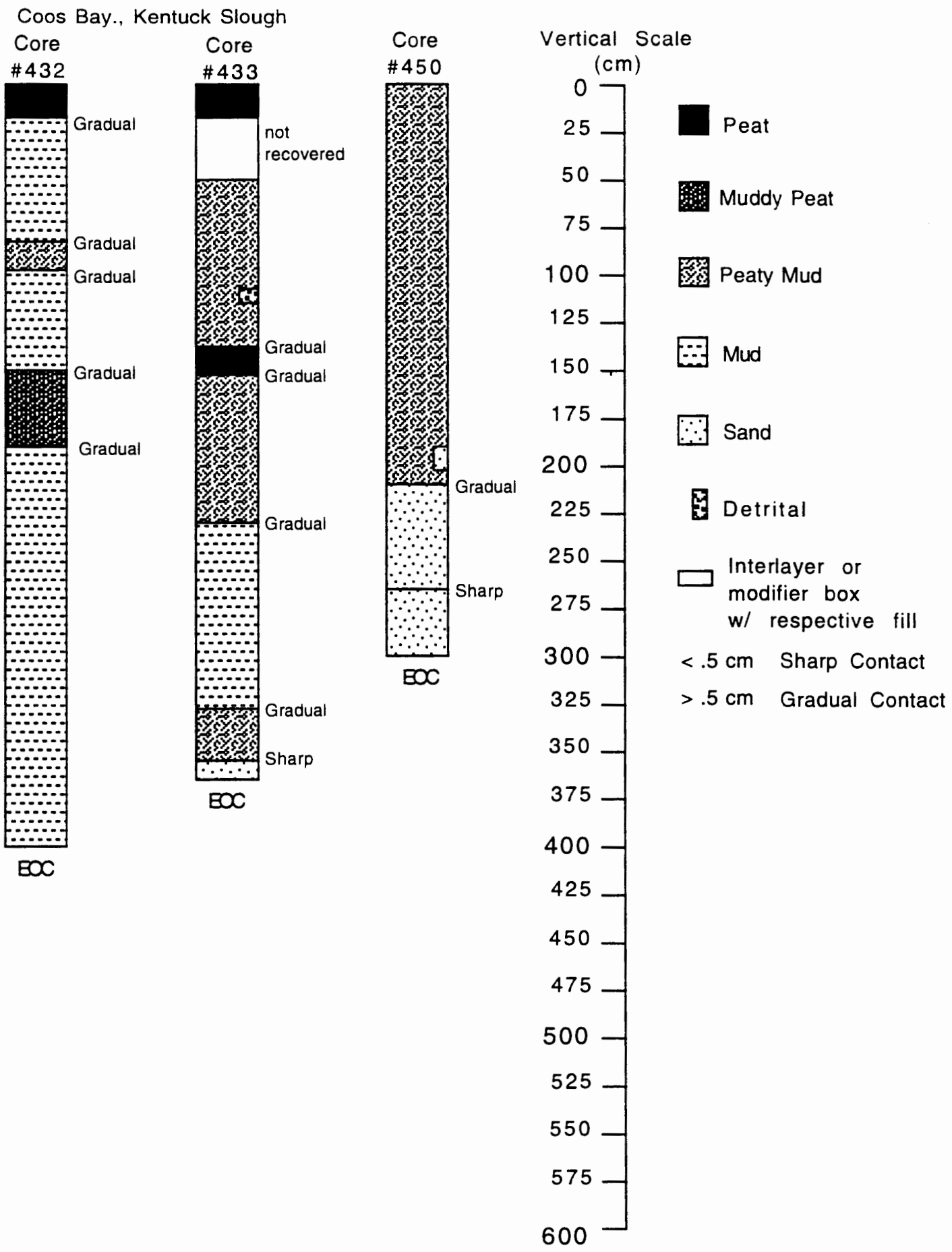


Coos Bay, pound cores

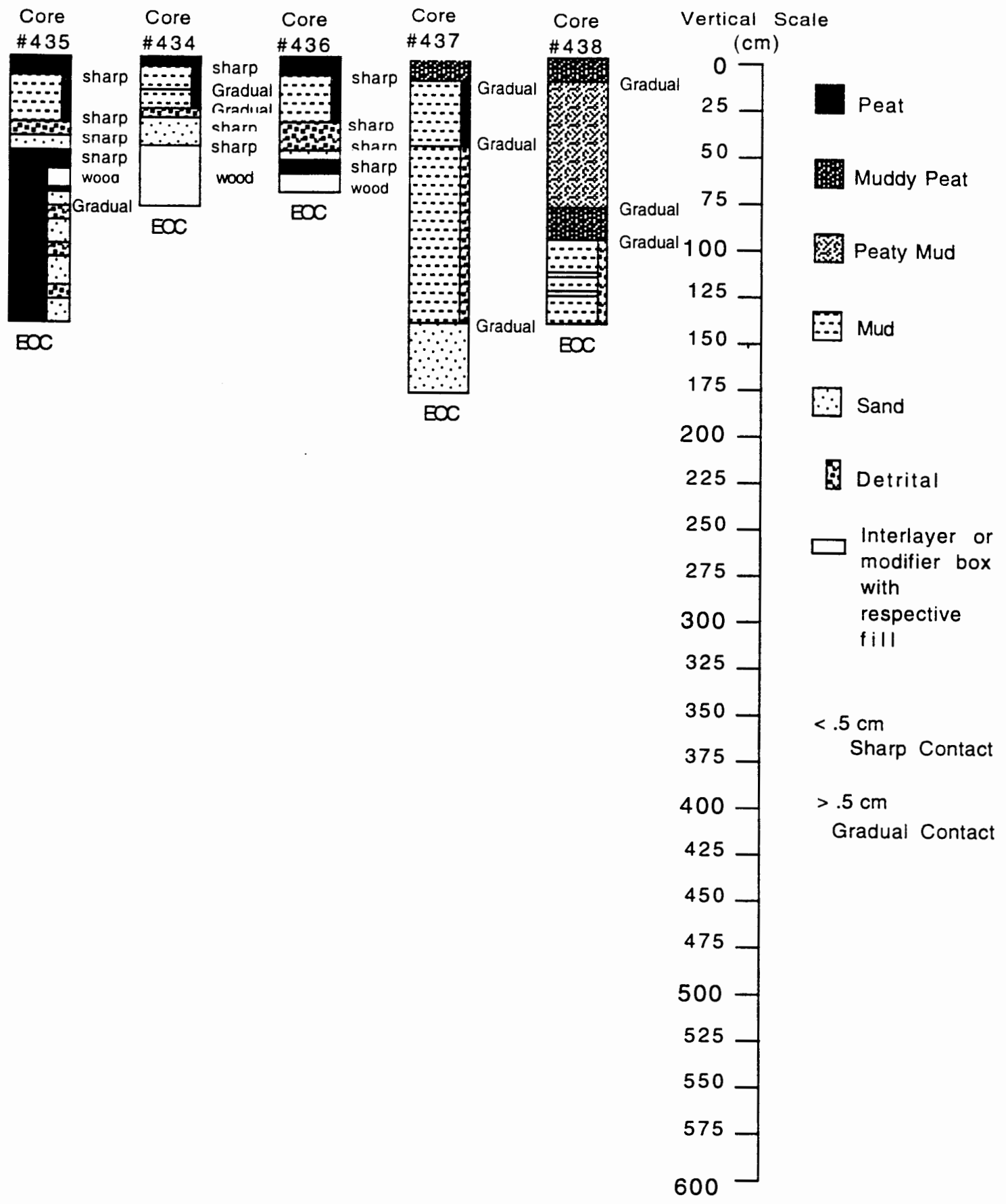



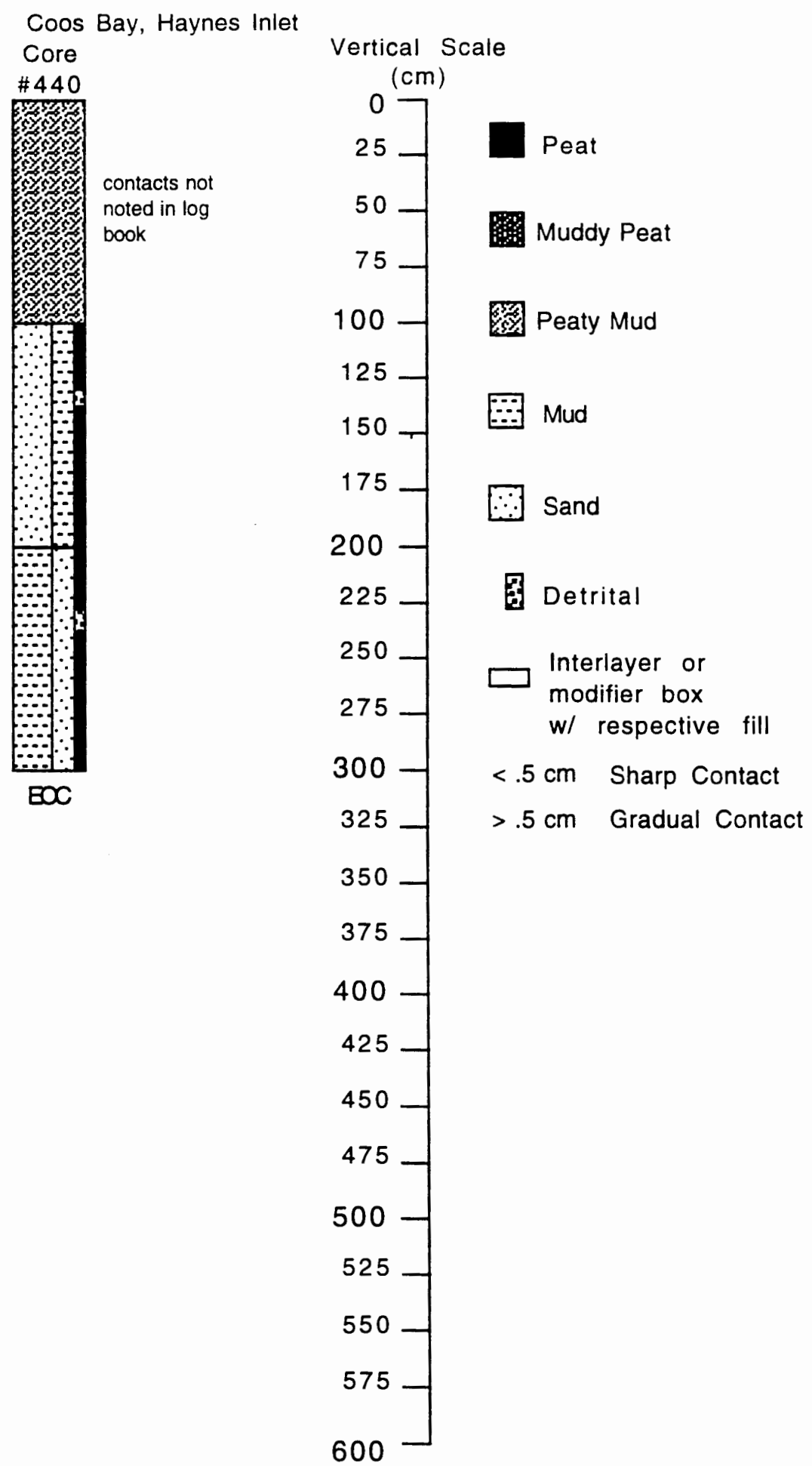


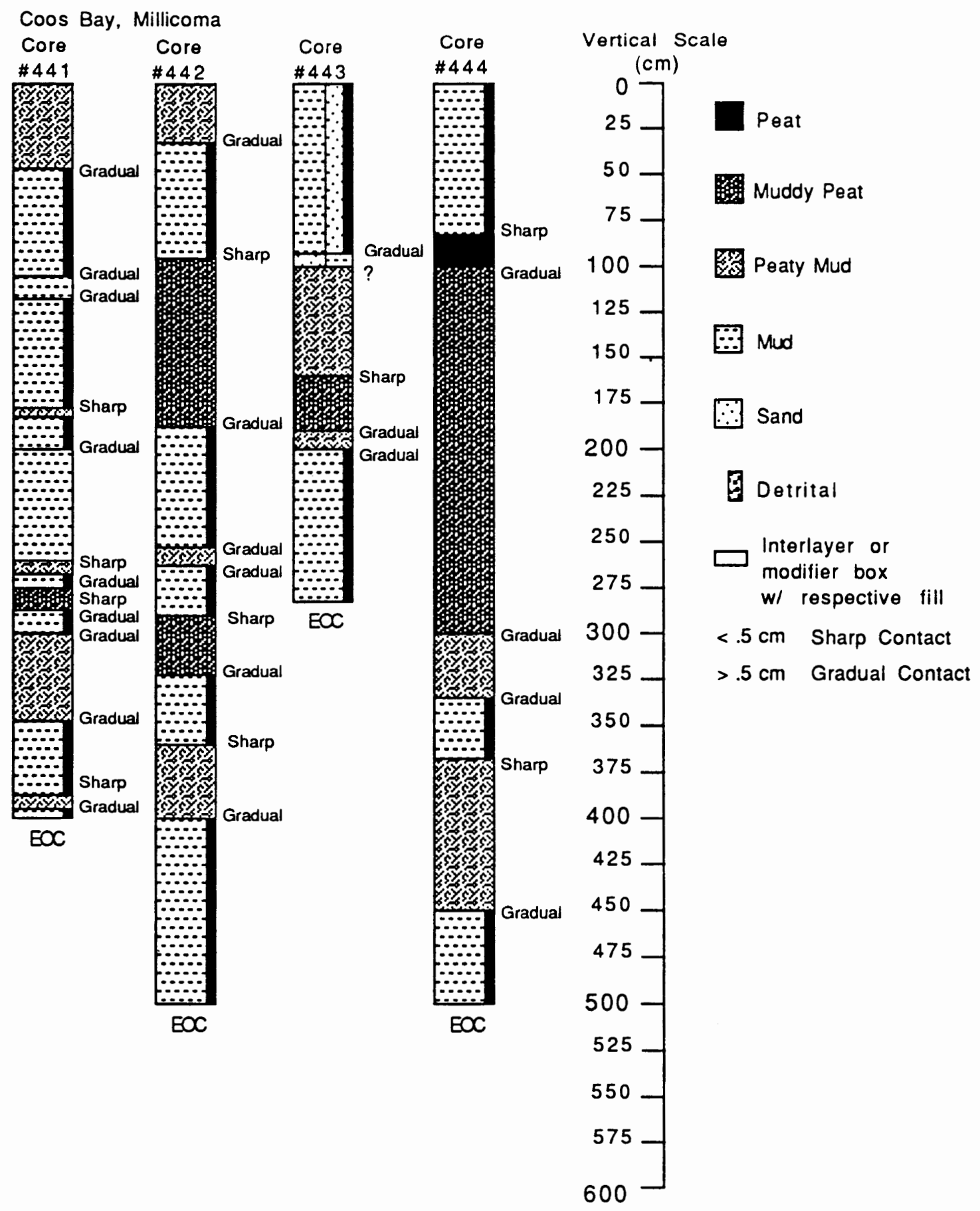


Coos Bay, Daniels Creek, South Fork

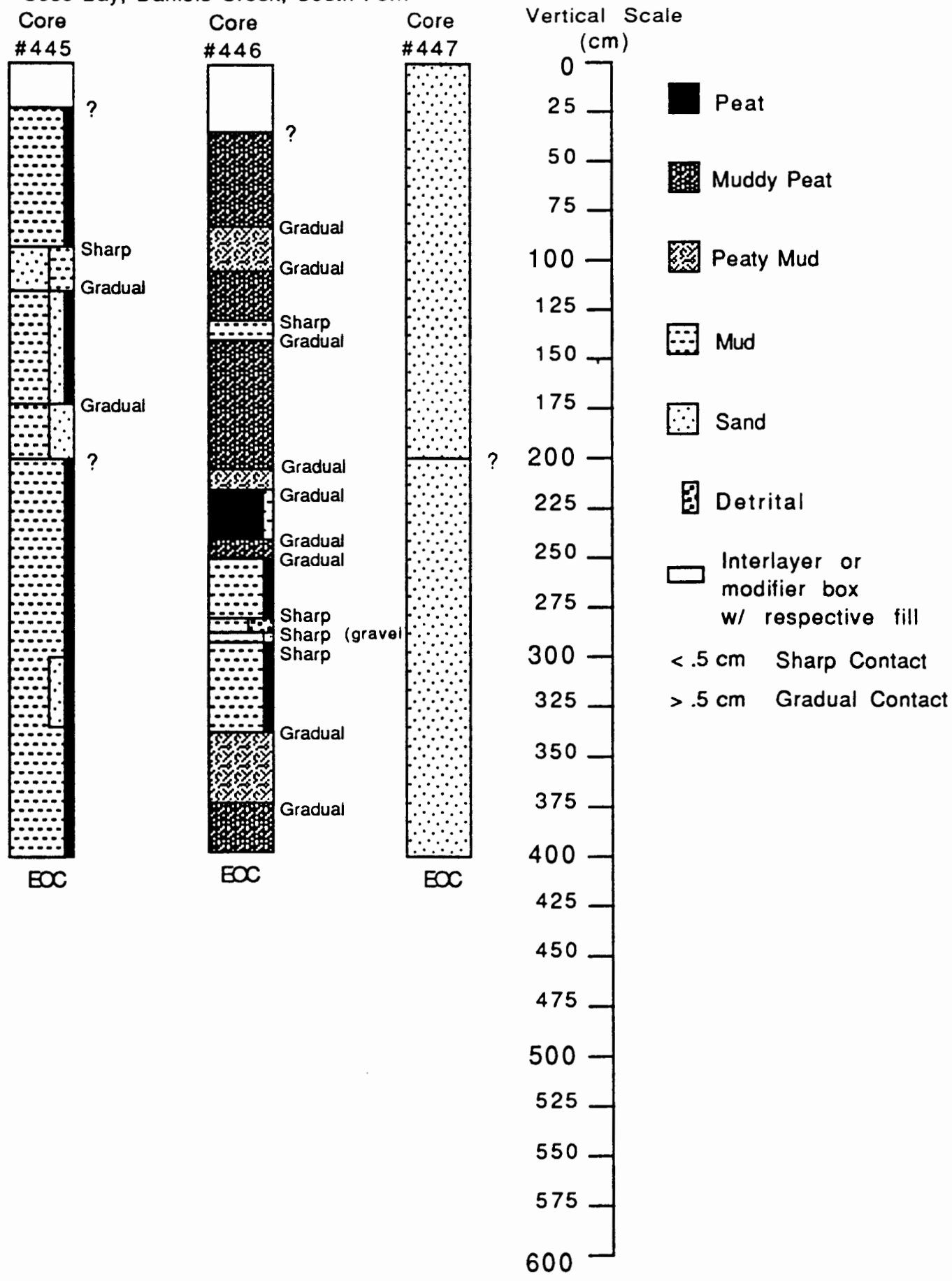



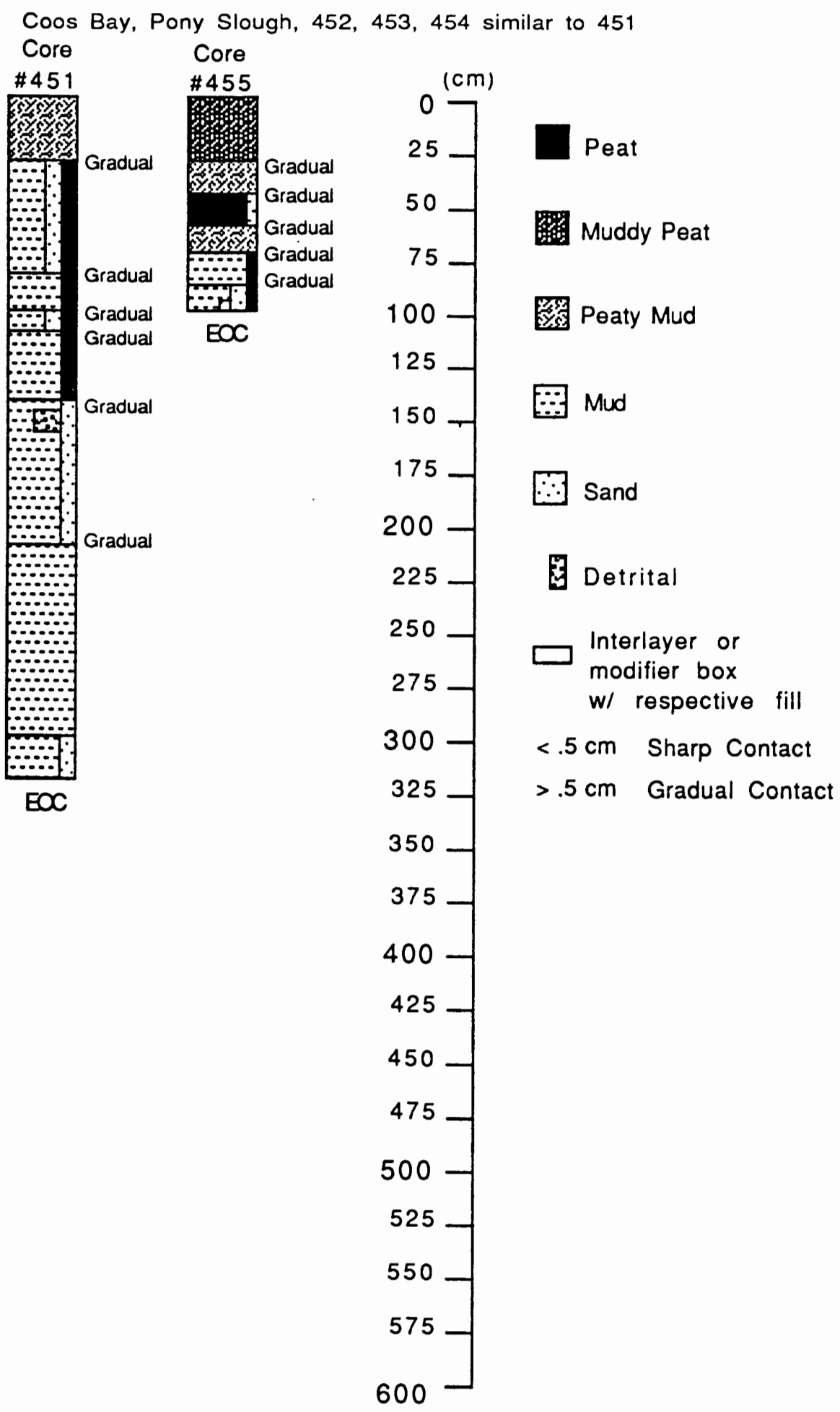
Coos Bay, Coalbank, 459 same as 458

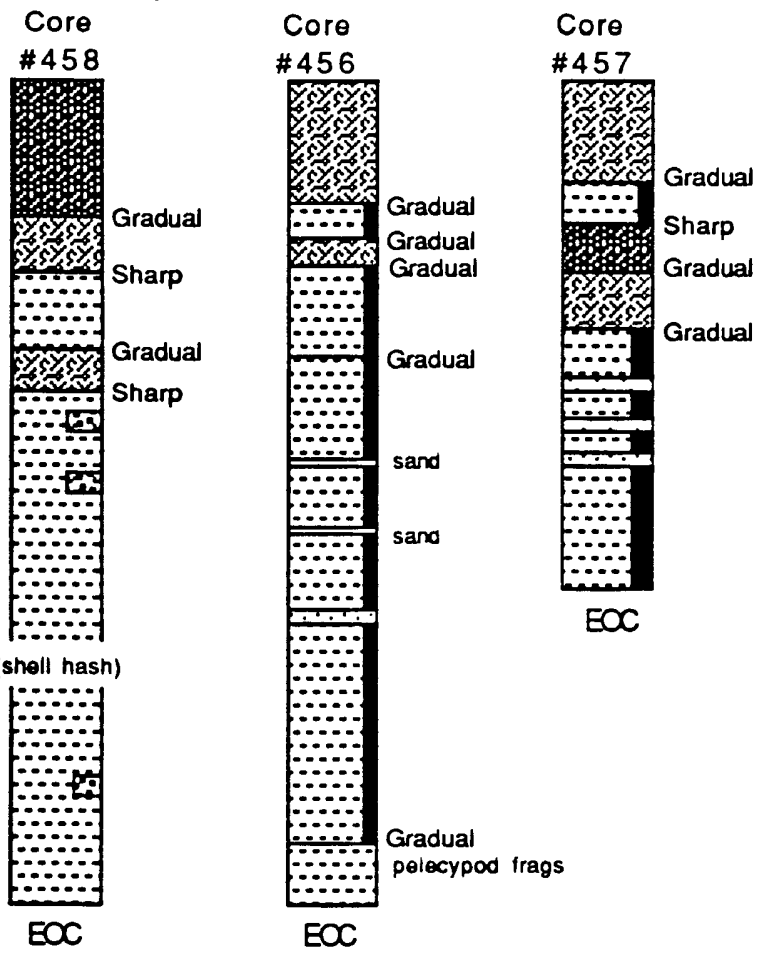

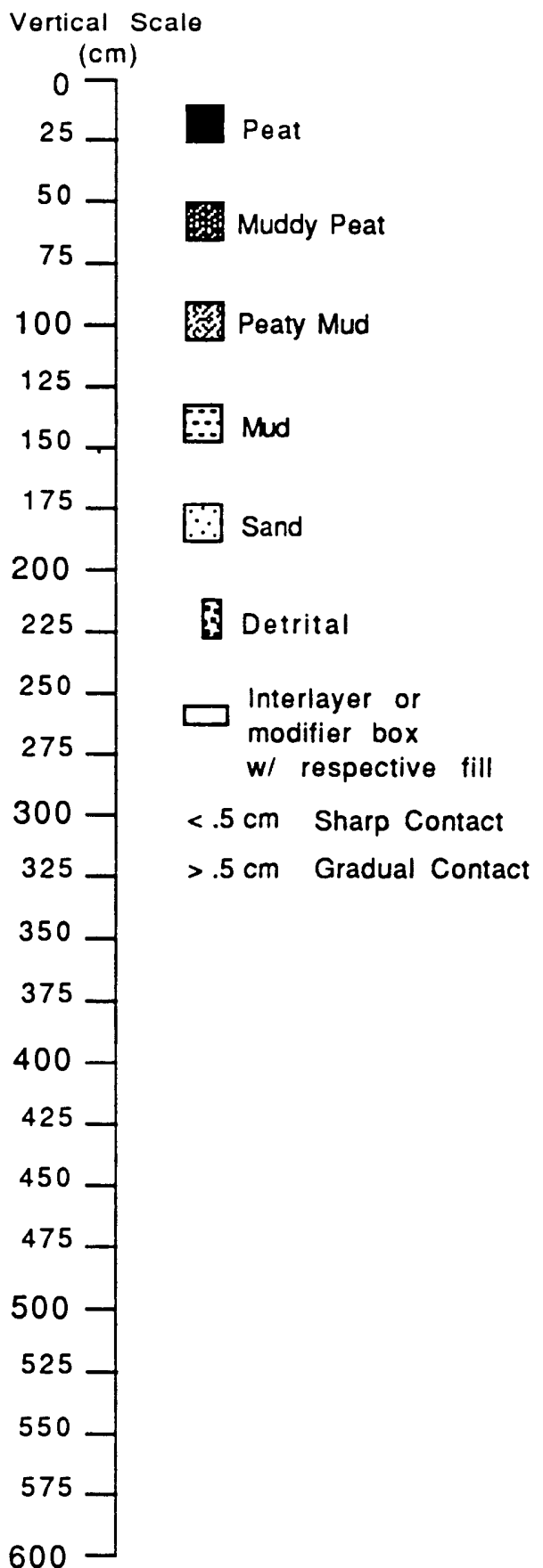




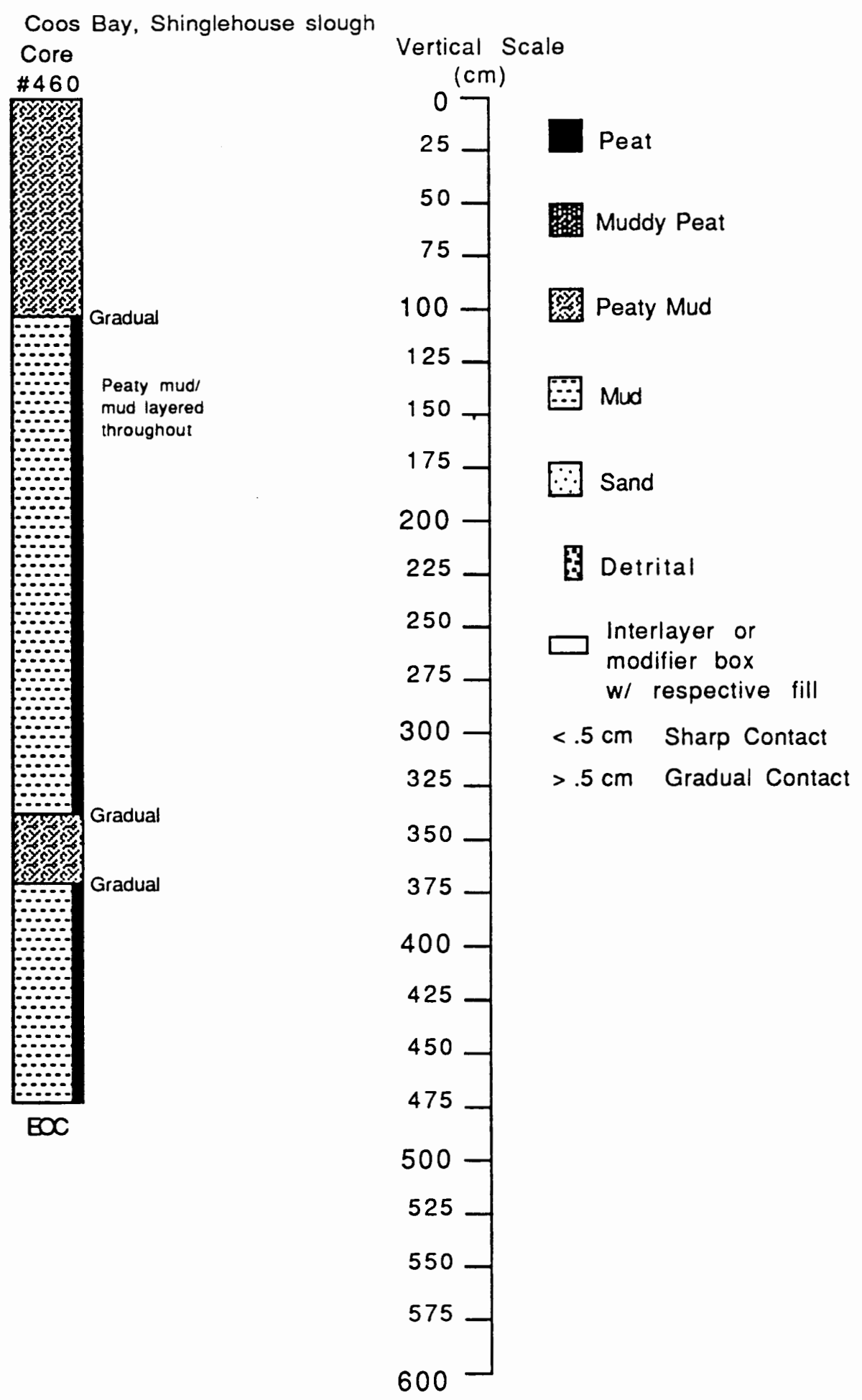




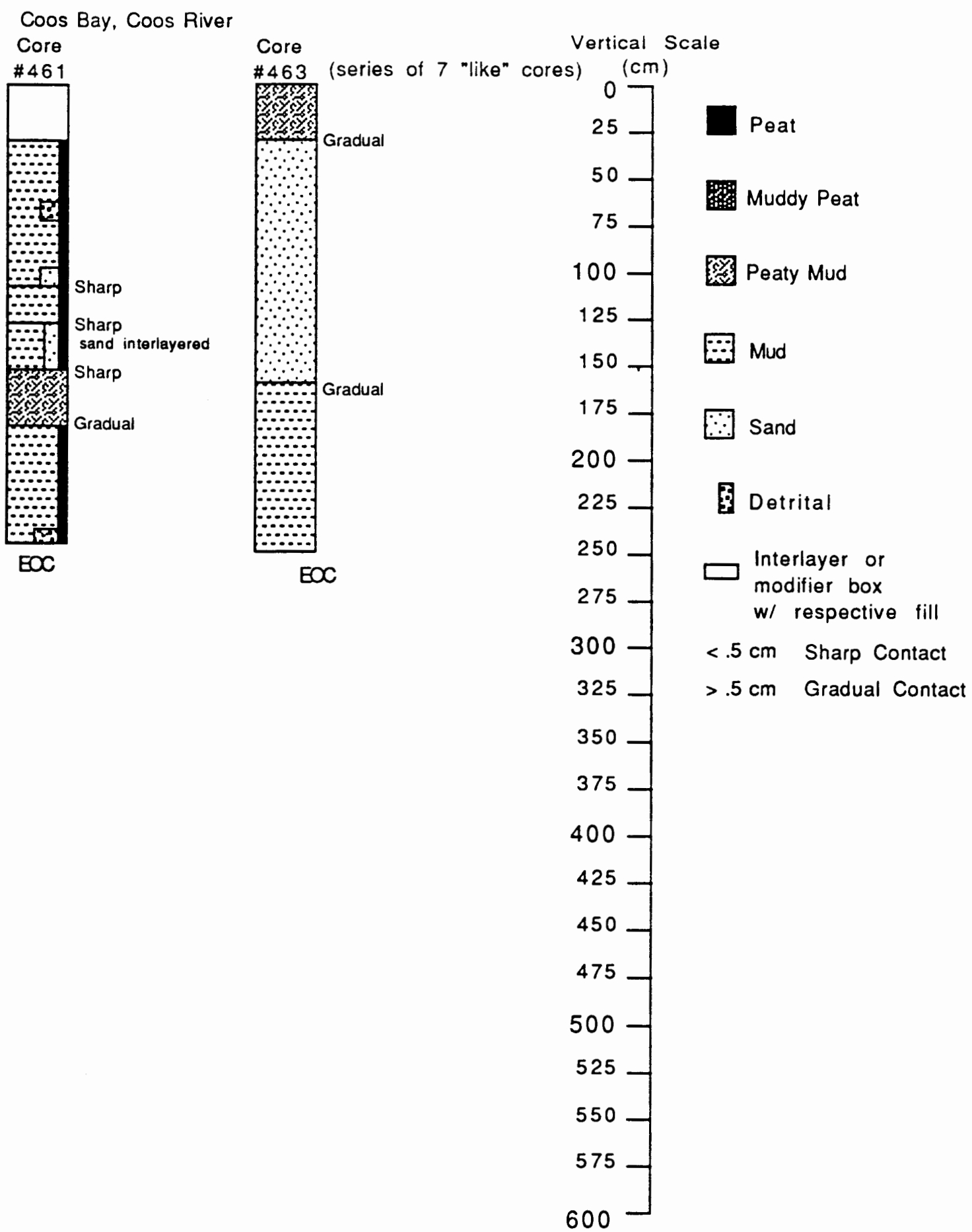



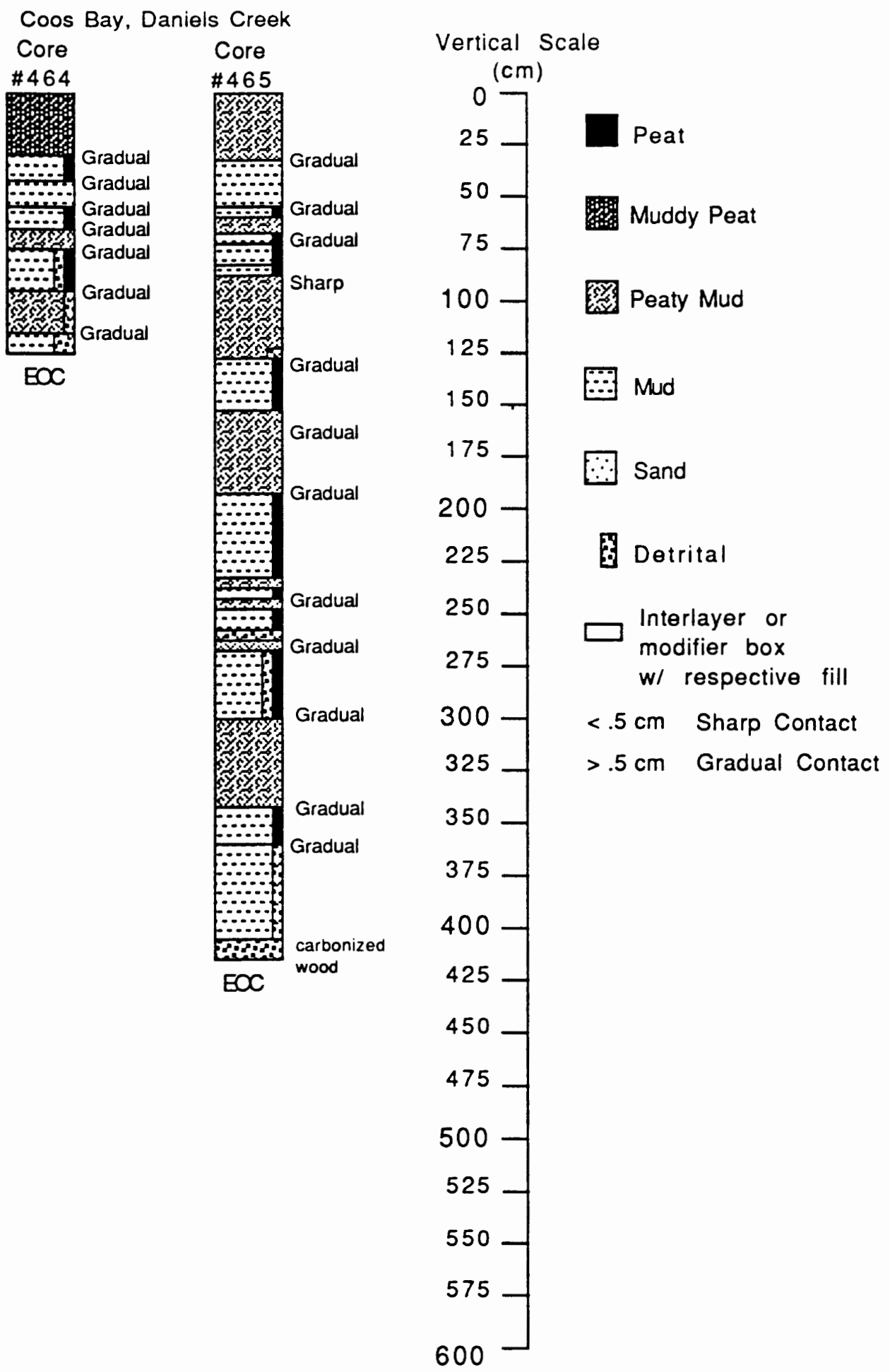
Coos Bay Cores, Coos River, George Smith's pasture

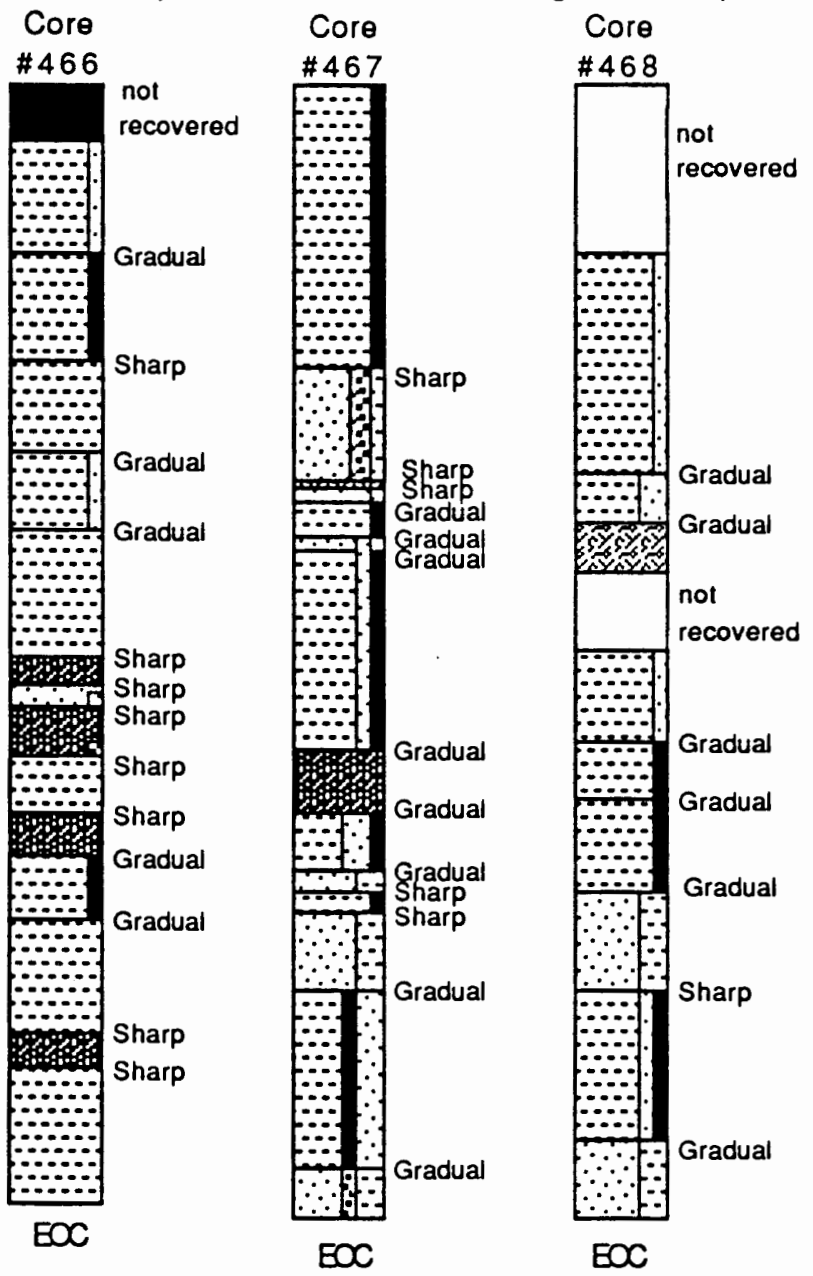

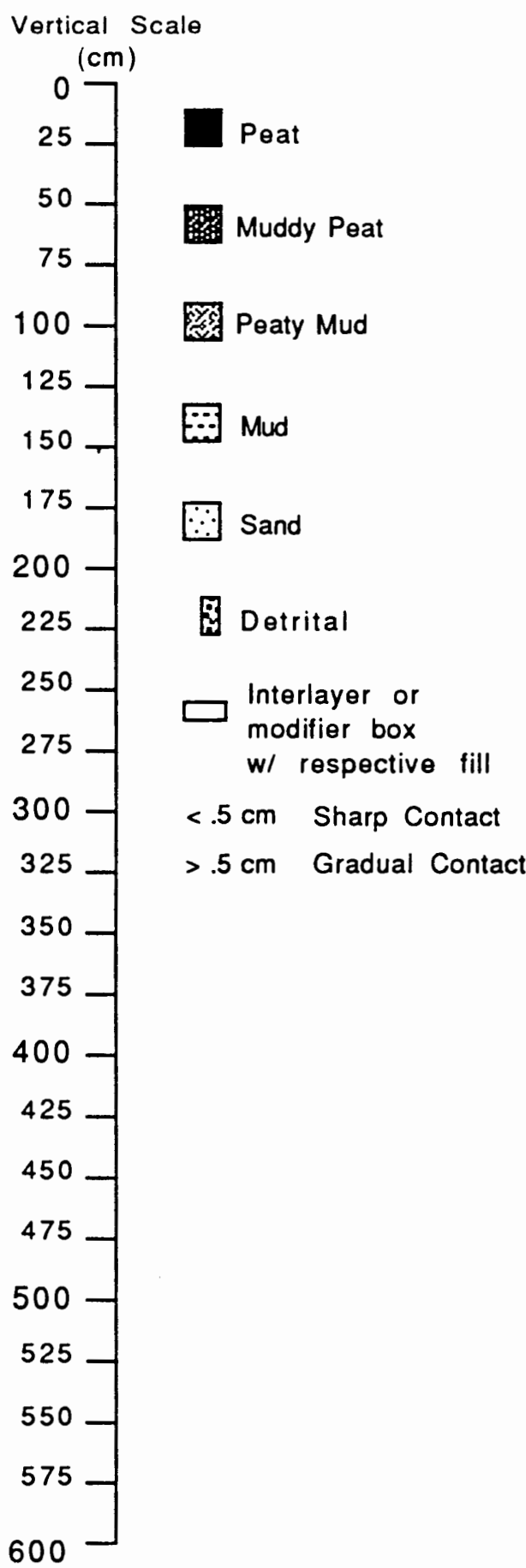


Coos Bay Cores, Coos River, George Smith Pasture

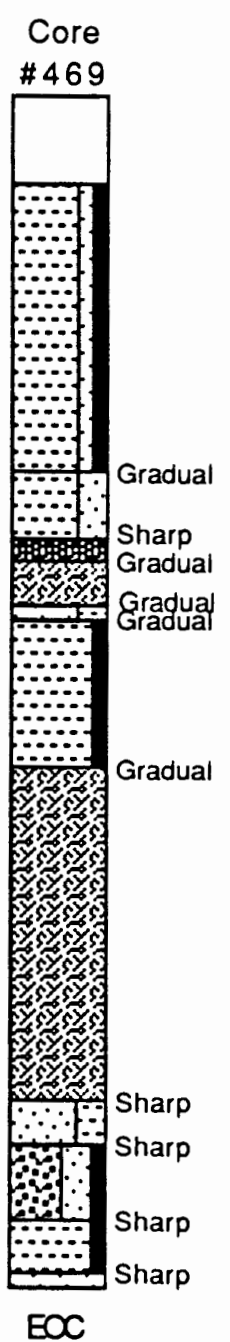

Vertical Scale

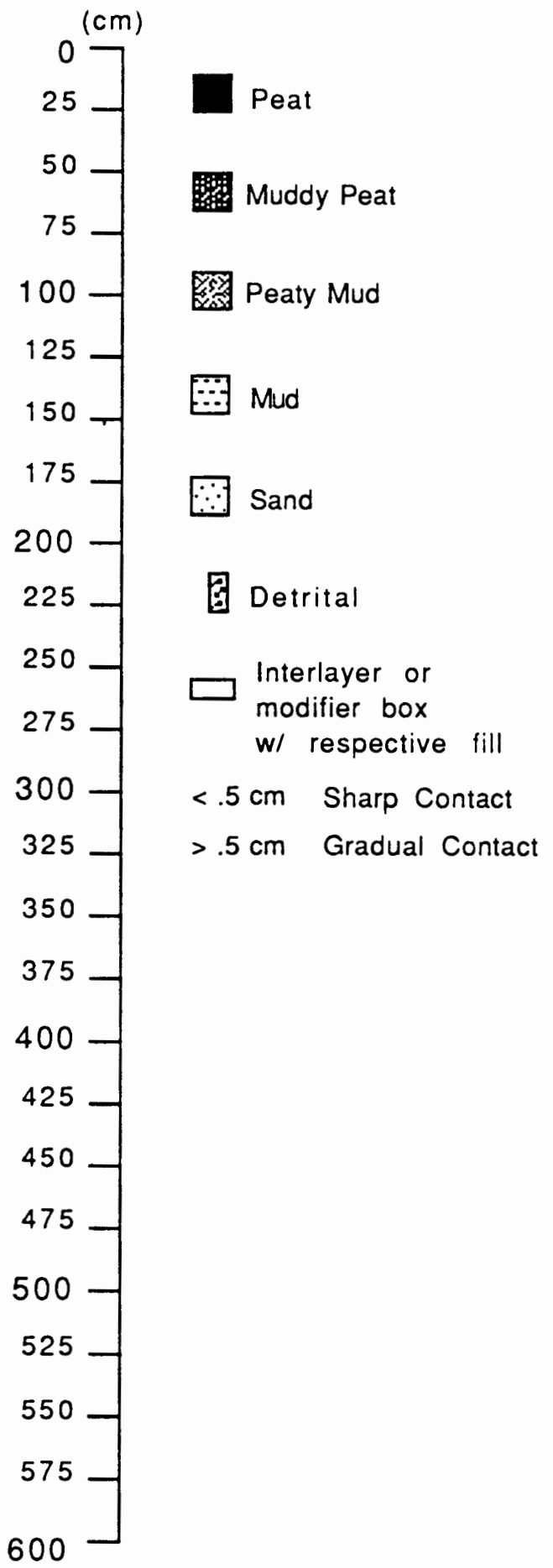


Coos Bay, Pony Slough, Pound Core

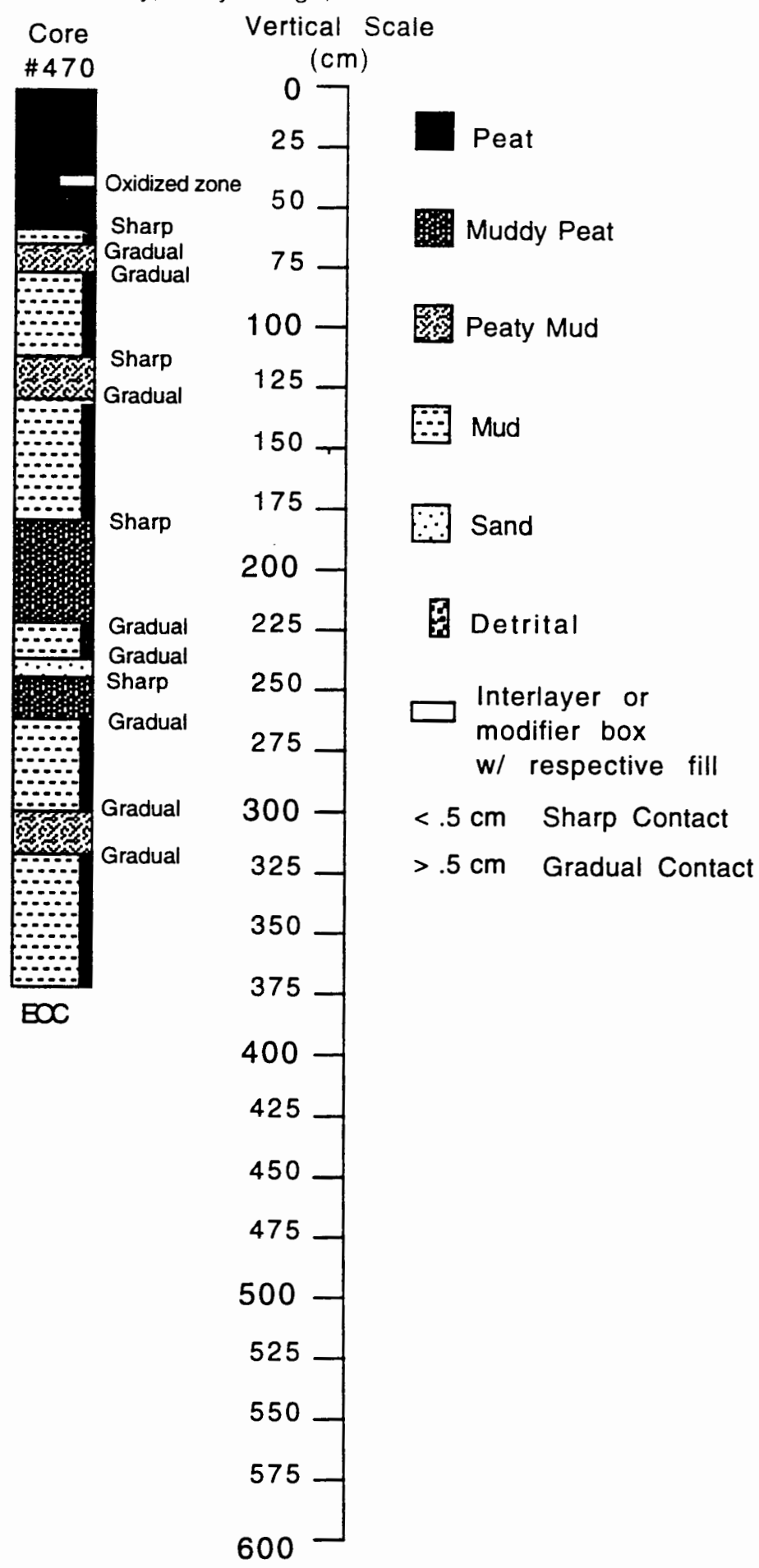


Coos Bay, Pony Slough

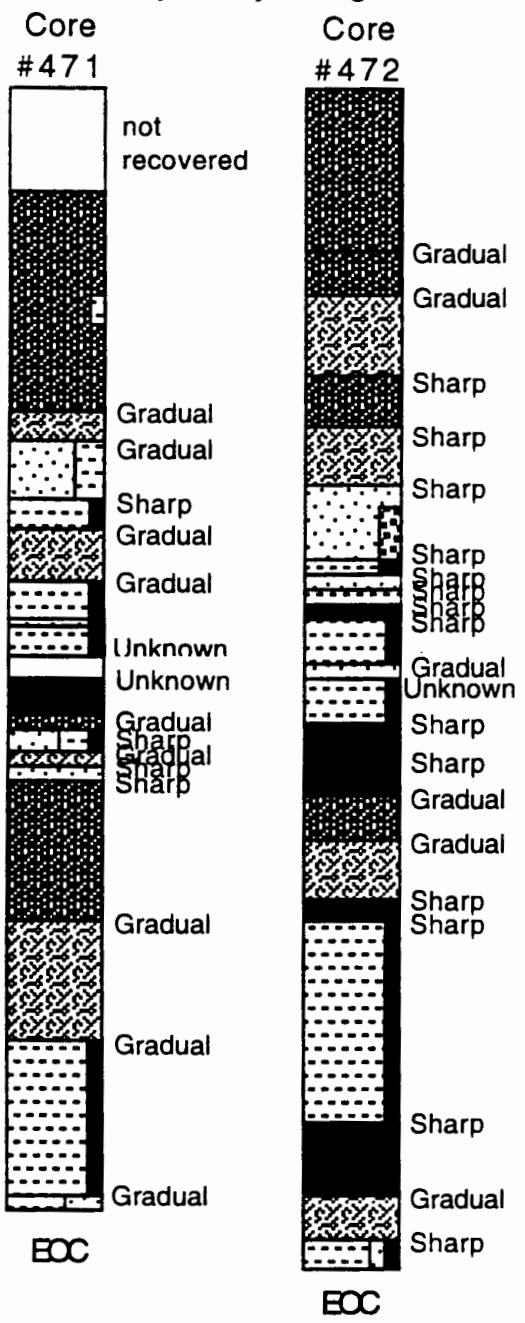

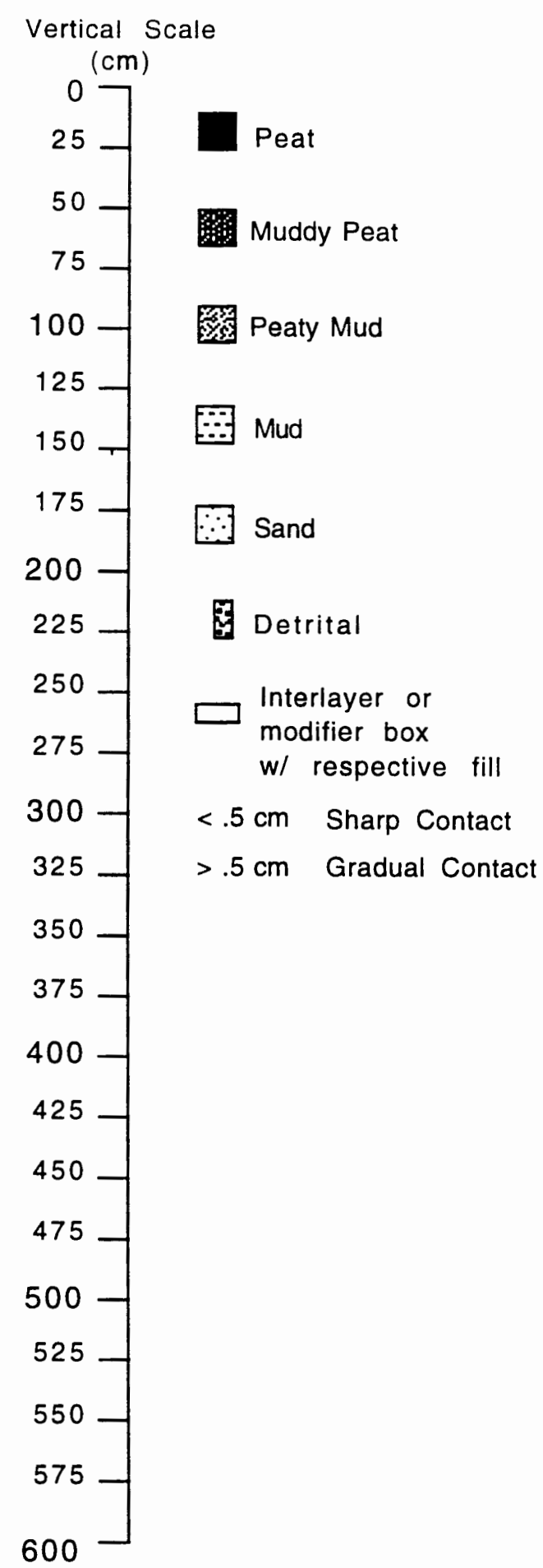


Coos Bay, Kentuck, 449--Pound Core
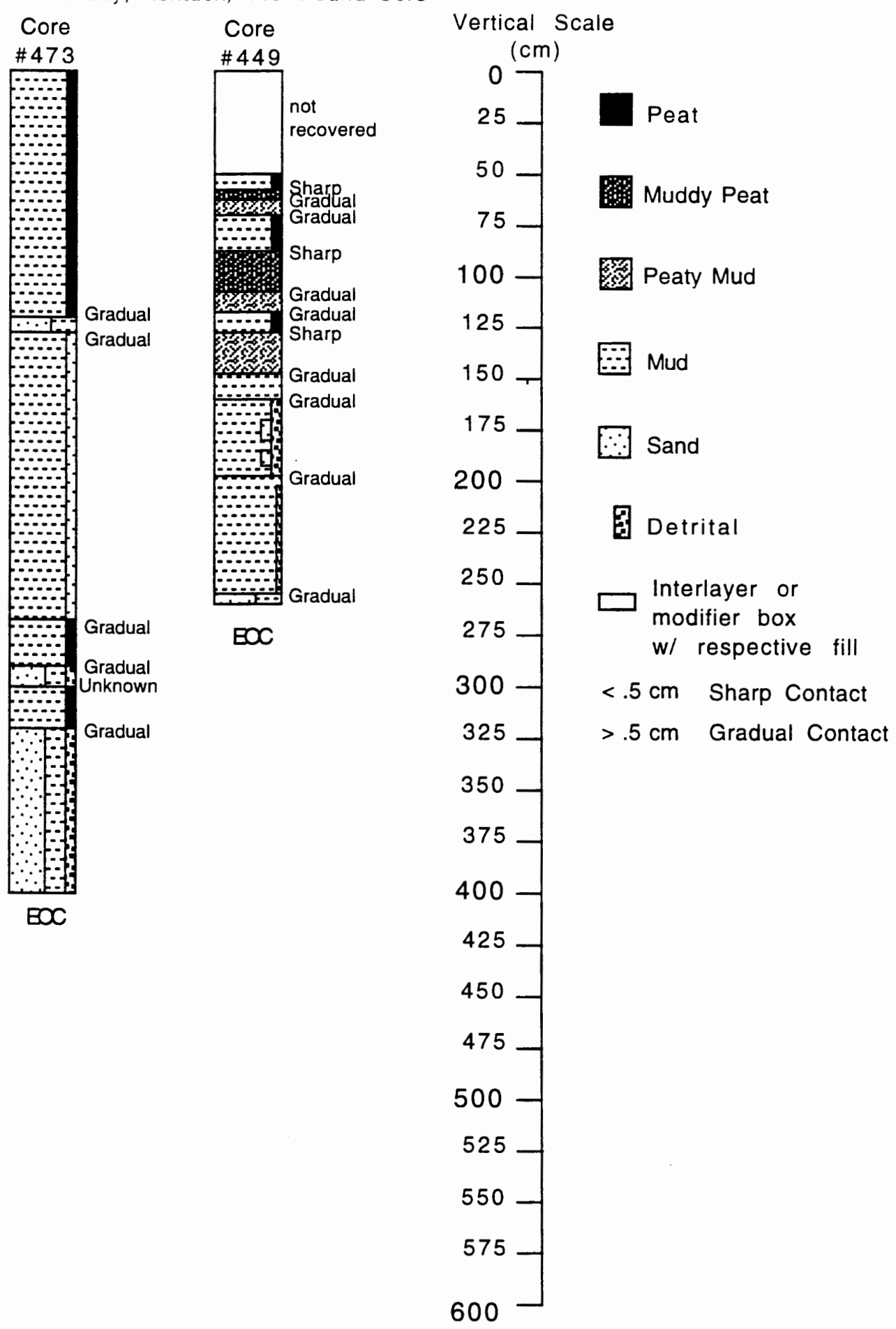


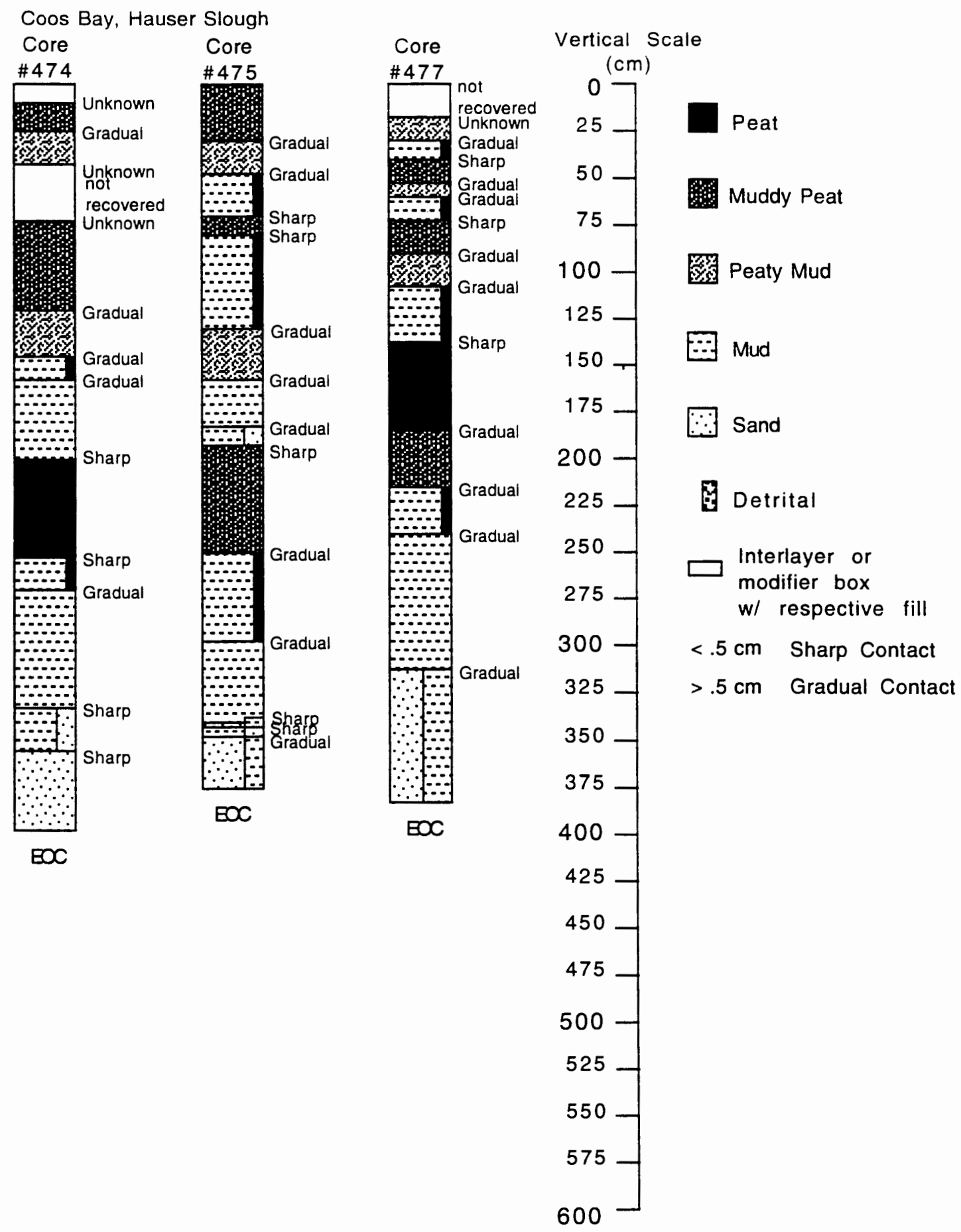


Coos Bay, Hauser, Pound Core 476

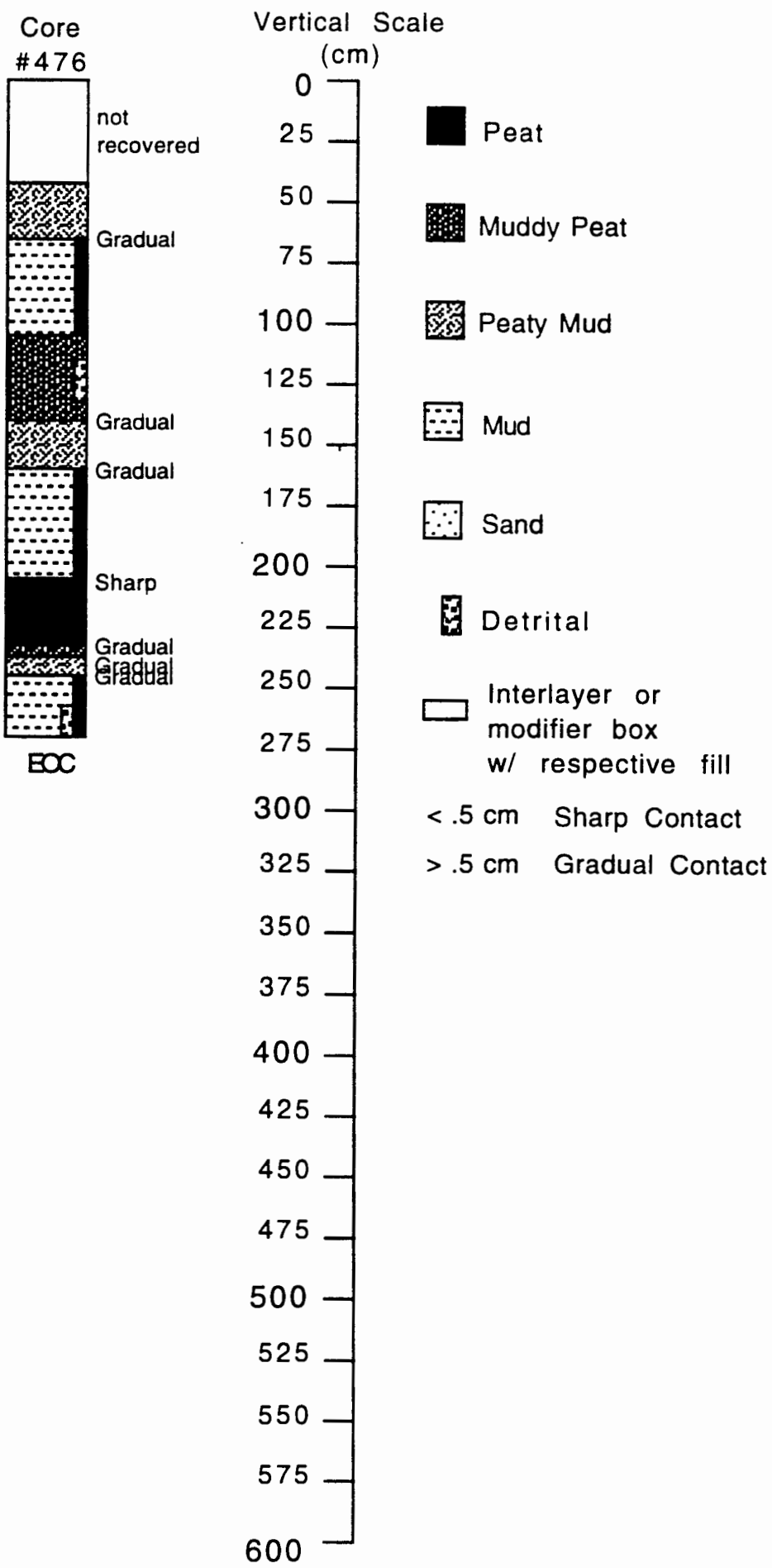


Coos Bay, Coal Bank SI.
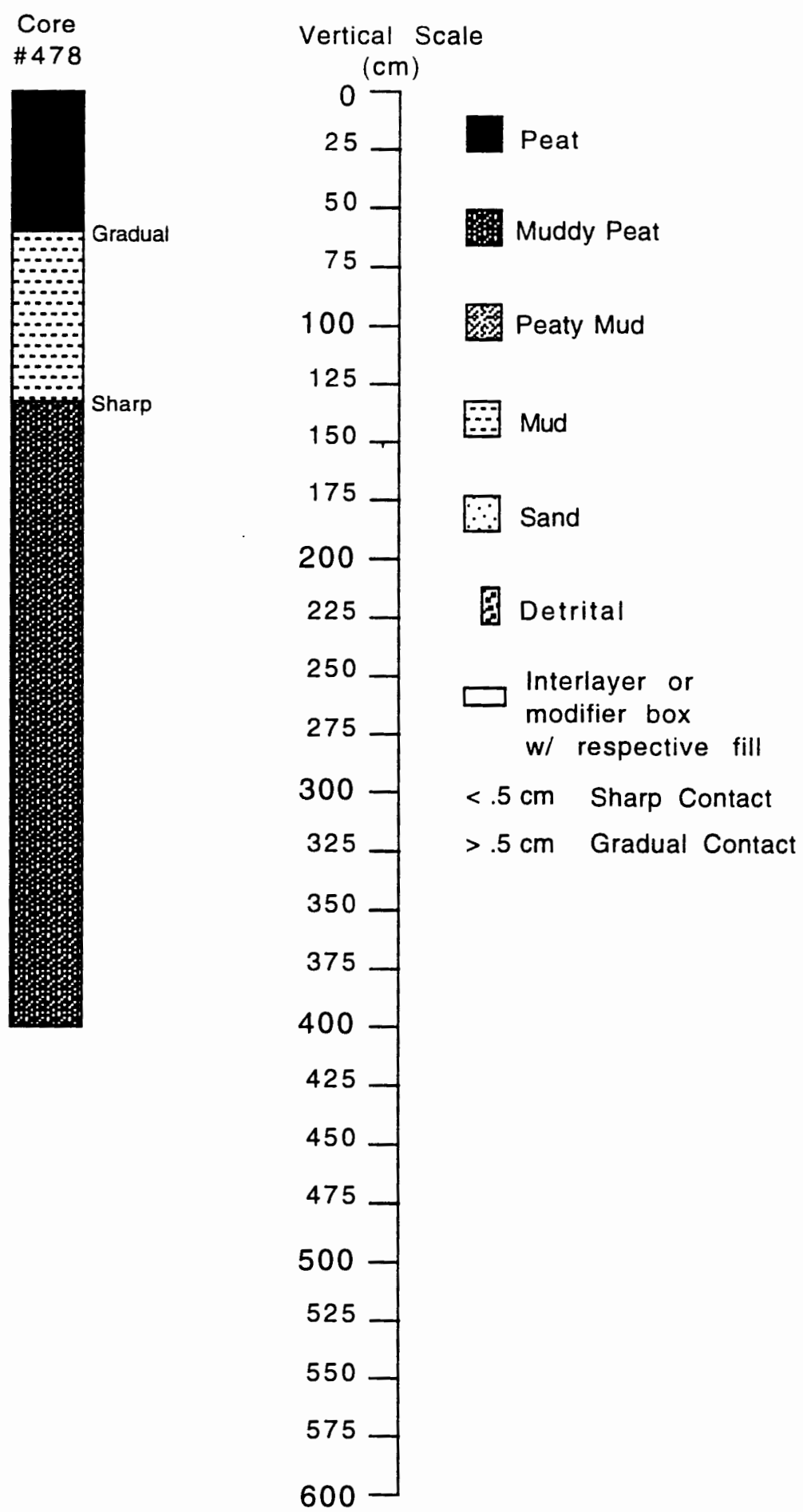
APPENDIX B

TOP OF CORE ELEVATIONS CORRECTED

TO MEAN SEA LEVEL (MSL) 
APPENDIX B

LIST OF CORE TOP ELEVATIONS

REFERENCED TO MSL

(* Surveyed Cores)

SIUSLAW AREA CORE NUMBERS

ELEV.

$\star 213(202,211,211,212 \pm 0.3 \mathrm{~m}$ of 213)

$+0.72 \mathrm{~m}$

$\star 216, \quad * 214$

$+1.89 \mathrm{~m}$

$\star 220(219,218 \pm 0.3 \mathrm{~m}$ of 220$)$

$+0.80 \mathrm{~m}$

$\star 222, \quad * 221$

$+1.10 \mathrm{~m}$

UMPOUA AREA CORE NUMBERS

\section{ELEV.}

*310

$+1.16 \mathrm{~m}$

*314

$+2.46 \mathrm{~m}$

$\star 316, * 317$

$+1.64 \mathrm{~m}$

*319, *330 (303, 305, 306, 307 $\pm 0.3 \mathrm{~m}$ of 319)

$+1.48 \mathrm{~m}$

*320(321 $\pm 0.3 \mathrm{~m}$ of 320$)$

$+1.21 \mathrm{~m}$

*336

$+0.59 \mathrm{~m}$

$\star 337, * 335$

$+0.76 \mathrm{~m}$

COOS BAY AREA CORE NUMBERS

ELEV.

$\star 401, \quad * 462$

$+2.65 \mathrm{~m}$

$\star 402$

$+2.10 \mathrm{~m}$

* 403

$+2.45 \mathrm{~m}$

$\star 404(434,435,436 \pm 0.3 \mathrm{~m}$ of 404$)$

$+1.93 \mathrm{~m}$

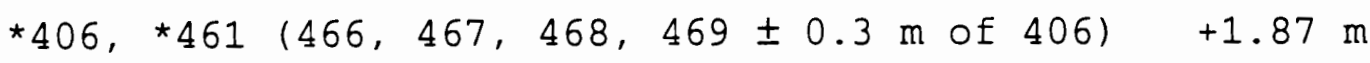


*417

* 422

$\star 423$

$\star 426, * 438$

*427

*428(437士0.3m of 428)

$\star 432$

*433， *449

$\star 448, \quad * 439$

*465 (464, $407 \pm 0.3 \mathrm{~m}$ of 465$)$
$-0.80 \mathrm{~m}$

$-2.44 m$

$-2.11 m$

$-0.02 \mathrm{~m}$

$-1.18 m$

$-0.98 m$

$+0.12 \mathrm{~m}$

$+0.74 \mathrm{~m}$

$-0.64 m$

$+0.53 \mathrm{~m}$ 


\title{
APPENDIX $C$
}

\author{
RADIOCARBON DATING ANALYSES \\ INCLUDING \\ BETA ANALYTIC LAB NUMBERS
}


APPENDIX C

LIST OF RADIOCARBON DATED SMAPLES

REFERENCED TO BETA LAB NUMBERS

CORE NUMBER

213

216

222

225

301

311

321

328

332

337

339

408

448
C-14 AGE YEARS B.P. \pm 10

$1880 \pm 80$ RCYBP

$540 \pm 70$ RCYBP

$1320 \pm 60$ RCYBP

$1540 \pm 70$ RCYBP

$1450 \pm 70$ RCYBP

$1910 \pm 70$ RCYBP

$30 \pm 90$ RCYBP

$1940 \pm 70$ RCYBP

$1840 \pm 80$ RCYBP

$3030 \pm 70$ RCYBP

$400 \pm 60$ RCYBP

$2530 \pm 80$ RCYBP

$310 \pm 50$ RCYBP (AMS)

$1420 \pm 80$ RCYBP

$2450 \pm 70$ RCYBP

$1270 \pm 90$ RCYBP

$2820 \pm 70$ RCYBP

$2960 \pm 60$ RCYBP

$2150 \pm 80$ RCYBP

$3140 \pm 70$ RCYBP

$1040 \pm 60$ RCYBP

$1630 \pm 60$ RCYBP

$1850 \pm 60$ RCYBP

$650 \pm 70$ RCYBP

$2350 \pm 90$ RCYBP

$2760 \pm 80$ RCYBP

$3620 \pm 160$ RCYBP

$1800 \pm 60$ RCYBP

$2830 \pm 100$ RCYBP
BETA LAB NUMBER

Beta- 67452

Beta-58116

Beta-67450

Beta-58117

Beta-67451

Beta-58118

Beta-58119

Beta-58120

Beta-67453

Beta-67454

Beta- 67455

Beta- 67456

Beta -67457

Beta -67460

Beta-58121

Bete-58122

Beta-58123

Beta-58124

Beta -67458

Beta-67459

Beta-58125

Beta-58126

Beta-58127

*Beta-27675

*Beta-27743

*Beta-34278

*Beta-34279

Beta-58137

Beta-58138 
Beta-58134

$1390 \pm 60$ RCYBP

Beta-58135

$1780 \pm 60$ RCYBP

Beta-58136

462

$3510 \pm 80 \mathrm{RCYBP}$

Beta- 67442

465

$1970 \pm 70$ RCYBP

Beta-58128

$3080 \pm 60$ RCYBP

Beta-58129

$4560 \pm 70$ RCYBP

Beta-58130

470

$1020 \pm 70$ RCYBP

Beta- 67437

$1400 \pm 80$ RCYBP

Beta- 67438

$1660 \pm 80$ RCYBP

$2900 \pm 80$ RCYBP

Beta-67439

$3700 \pm 90$ RCYBP

Beta-67440

Beta-58133

476

$1780 \pm 90$ RCYBP

$1930 \pm 70$ RCYBP

Beta-67441

Beta-58139

478

$1740 \pm 100$ RCYBP $2920 \pm 60$ RCYBP

Beta-67443

Beta- 67444

*Note: from Peterson and Darienzo, Abstract, 1989. 